CUSTOMARY LAND RIGHTS AND TENURE SECURITY OF SUBSISTENCE FARMERS FOR FOOD SECURITY IN NORTHERN GHANA 



\title{
Customary land rights and tenure security of subsistence farmers for food security in northern Ghana
}

\author{
DISSERTATION
}

to obtain

the degree of doctor at the University of Twente, on the authority of the rector magnificus, prof.dr.ir. A. Veldkamp on account of the decision of the Doctorate Board, to be publicly defended on 14 day of October 2021 at 14:45 hrs

by

Baslyd Begerr Nara

Born on 27th April, 1968

in Techiman, Ghana 
This thesis has been approved by

Prof.mr.dr.ir. J.A. Zevenbergen, promoter

Dr. M.N. Lengoiboni, co-promoter

ITC dissertation number 402

ITC, P.O. Box 217, 7500 AE Enschede, The Netherlands

ISBN 978-90-365-5206-6

DOI $10.3990 / 1.9789036552066$

URL https://10.3990/1.9789036552066

Cover designed by B. Nara/J. Duim

Printed by CTRL-P, Hengelo

Copyright (c) 2021 by Baslyd Begerr Nara

\section{UNIVERSITY OF TWENTE.}

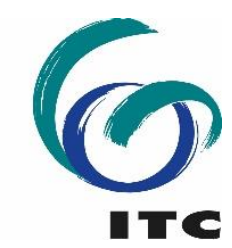


Graduation Committee:

\section{Chairman/Secretary}

Professor dr. ir. F.D. van der Meer

Promoter

Prof.mr.dr.ir. J.A. Zevenbergen

\section{Co-promoter}

dr. M.N. Lengoiboni

\section{Members}

Prof.dr. A.D. Nelson - University of Twente, Netherlands

Prof.dr.ir. C.H.J. Lemmen - University of Twente, Netherlands

Prof.dr. J.T. Bugri - Kwame Nkrumah University of Science and Technology (KNUST), Ghana

Dr.ir. M.W. Ertsen - Delft University of Technology, Netherlands 
To my wife Saahn - Rita Mmello Nara.

To my daughters Nuo-ere and Aviella and my son Nyemaalo. The start of this PhD journey was the first time I stayed away from them for long - it was hard for us all. My son once remarked "so won't Papa come ...?" Their sacrifices and prayers have paid off to the Glory of God. 


\section{Acknowledgements}

I acknowledge a three-year collaborative work between a UK based organisation - Development Partnerships in Higher Education (DelPHE) and the University for Development Studies, Wa campus with the instrumentality of Professors Lenny Baer and Saskia Veymelen. It was Professor Lenny who obtained the funds from DelPHE for the project while Professor Saskia supervised the research work visiting Ghana from time to time. While carrying out the DelPHE research work, my PhD topic crossed my mind and at a certain stage Professor Saskia remarked thus "if I were Ghanaian, I would investigate this further... Nara, I think you can pursue this for your PhD studies." Even as the project was not renewed at the end of its first three years, my PhD research idea was conceived and carried forward.

It was extremely difficult to obtain funding from countless funding sources including Ghana Education trust Fund (GETFund). At a certain point my colleague and friend - Samuel Biitir encouraged me to try GETFund since I will not really lose much by applying. But in order to obtain GETFund funding, I needed at least an admission and so I applied to ITC. Soon after, I enquired from Bonhke of ITC about funding opportunities and was introduced to the Netherlands Universities Foundation for International Cooperation (NUFFIC, now OKP). I duly acknowledge the funding opportunity from NUFFIC.

Thanks to my committed supervisors, Professor J.A. Zevenbergen as my promoter and Asst Professor Monica Lengoiboni as co-promoter. Their high level of team spirit and support for my progress are par excellence. Particularly, Monica works best with due dates (deadlines) and therefore time conscious. At the same time, she can be flexible depending on the prevailing circumstances, all geared towards the success of this thesis. Jaap on the other hand is so meticulous that hardly the crossing of a ' $t$ ' or dotting an ' $i$ ' escapes his "eagle eyes." My appreciation gesture for these is to replicate this level of commitment to the students I will be handling from now.

I am further particularly grateful to the Landowners, Chiefs and people including settlers of all my study communities that I visited. They are Sing, Kunfabiala, Nimoro, Fielmua, Piina number One and Piina number Two. The people did not only allow me entry into their communities and lives but they also committedly and willingly provided me with every information that I needed for this research. Without their support, this research may not have been complete yet. Certain individuals in these communities deserve special mention. These are Abdulai Issahaku and Alhaji Salia Danyagri of Sing. Piina Unit Committee member - Hon. Yussif Sobryaga and the Piina Assembly man - Michael Bedereh including Akadius Kyibiineh also of Piina and the Piina chief - Louis Naaweh. The others are the Nimoro Unit Committee member - Michael Chommbui and Fielmua Unit Committee member - Godfred Nyuurzie.

I acknowledge two particular ITC lecturers who contributed variously to my $\mathrm{PhD}$. The first is Dr. Paul van Asperen who read portions of my research proposal, attended my qualifier and "identified with me" during my early months in Enschede. And the second being Professor Richard Sliuzas who 
surprised me by emailing to me some relevant materials about my topic that he found. I deeply thank all ITC-UT staff also like Petra, Mafalda and others for your enormous contributions in various ways.

I acknowledge also, two senior Ghanaian PhD colleagues - Dr. Kwabena Obeng Asiama and Dr. Abubakari Zaid who offered various forms of direction and advice, having enrolled in this PhD programme two and one year(s) before me respectively. They lead me enough to maneuver and navigate through the tough PhD terrain.

Let me also acknowledge the Ghanaian community and my ICF church family in Enschede who provided me with the needed physical, moral and spiritual support throughout the four-year duration of the programme. So, let me make special mention of Brothers Kwame Avianne, Emmanuel Adugbila, Maxwell Owusu and Ebenezer Ofosuhene. Others are sister Leticia Amoakoa Owusu and finally, Dr. Paul van Dijk who provided mentorship for me in ICF.

The following people also helped in the data collection and more. They are Miller Appau, Mohammed Osman Banyellibu, Benedict Akpem and Urbanus Wedaaba. Others are Tahiru Yahaya and Oliver Tannor as well. The officers of the Upper West regional Lands Commission, the Wa Central Customary Lands Secretariat and Meridia Ghana have all been helpful in contributing useful information for the success of this research.

Professor Francis Z.L. Bacho, Dr Elias Kuusaana and Professor Emmanuel K. Derbile were also supportive in diverse ways of my PhD study programme. Without their support, this dream would not have materialised. So, to them I say "barka yaga."

Let me finally acknowledge Job Dium, a staff of ITC for designing the cover pages of this thesis. "Dank je wel", Job. 


\section{Table of Contents}

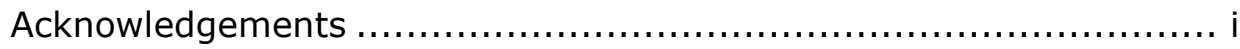

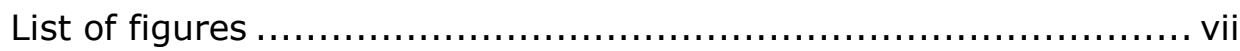

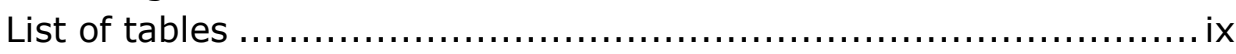

Chapter 1 Introduction ................................................... 1

1.1 Food Security: Perception and dimensions ........................ 6

1.2 Knowledge Gap ..................................................... 7

1.3. The Research Problem, Objectives and Questions ............... 8

1.3.1. Statement of the problem .................................. 8

1.3.2. Research objectives and Questions ......................... 9

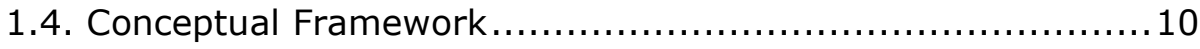

1.5. Research Design.............................................. 12

1.5.1. Models of land tenure and food security ..................... 13

1.5.2. Requirements for an effective model ....................... 15

1.6 Methodological issues............................................ 16

1.6.1. Case Study Area and its land tenure forms ................. 16

1.6.2. Methods used ............................................... 19

1.7. Outline of Research ............................................22

Chapter 2 Assessing customary land rights and tenure security variations of smallholder farmers in northwest Ghana .................23

2.1 Introduction: indications of land rights variations ...........24

2.2 Nature, causes and arguments of land rights variations.........26

2.3 Customary land tenure system and evolution of land rights in

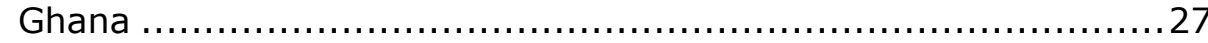

2.4 Settlement antecedents in Upper west region $\ldots \ldots \ldots \ldots \ldots \ldots \ldots 28$

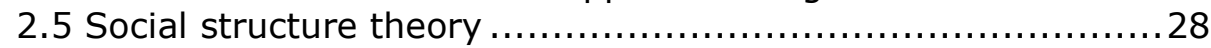

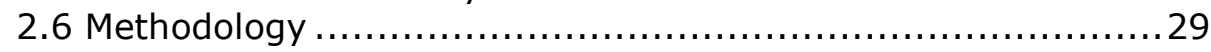

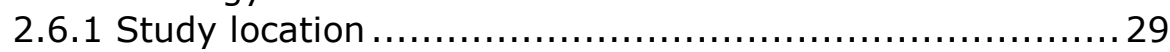

2.6 .2 Fieldwork ....................................................... 30

2.6.3 Interview respondents and FGD participants ............... 31

2.6.4 Spatial data and other data ............................... 32

2.6.5 Data analyses ................................................ 32

2.7 Results............................................................. 33

2.7.1 General nature of customary land rights in the study area

2.7.2 Land rights variations between landowners and settlers .. 36

2.7.3 Gender variations of customary land rights .................. 41

2.7.4 Variations between rural and urban land rights and tenure issues ......................................................... 43

2.7.5 Age and land rights variations $\ldots \ldots \ldots \ldots \ldots \ldots \ldots \ldots \ldots \ldots . \ldots \ldots$ 
2.7.6 Variations of customary land rights based on disability ... 50

2.8 Discussion ....................................................... 50

2.8.1 Variations of landowner and settler land rights .............50

2.8.2 Gender land rights differences............................. 52

2.8.3 Rural and urban land rights variations ...................... 54

2.9 Conclusion and recommendations............................... 56 Chapter 3 Implications of customary land rights inequalities for food security: A study of smallholder farmers in northwest Ghana .........59

3.1 Land Rights and Tenure Security...........................60

3.1.2. Customary Land Rights Inequalities and Food Production 61

3.1.3. Food Security and Its Dimensions ........................... 62

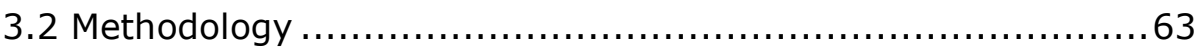

3.2.1. Description of Study Area ................................... 64

3.2.2. Selection of Participants for Focus Group Discussions ..... 65

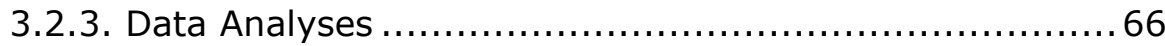

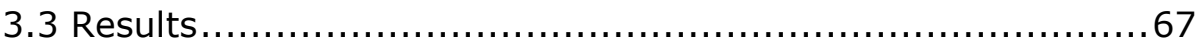

3.3.1. Nature of Land Rights Inequalities .......................... 67

3.3.2. Implications for Farming, Food Availability and Food Security .................................................... 71

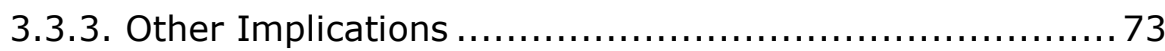

3.4 Discussions ...................................................... 74

3.4.1. Nature of Land Rights Inequalities ......................... 75

3.4.2. Implications for Food Production, Food Availability and Food Security .............................................. 76

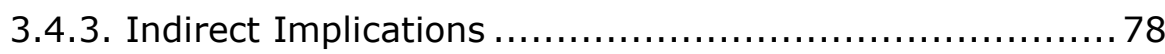

3.4.4. Conclusion and Recommendations .......................... 79

Chapter 4 Influences of community land rights and tenure security intervention processes on food security in northwest Ghana...........81

4.1 Introduction ....................................................... 82

4.1.1 Land tenure security, challenges and mechanisms to

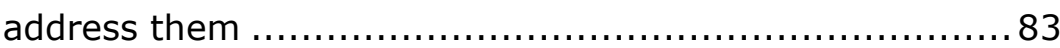

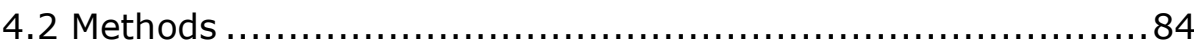

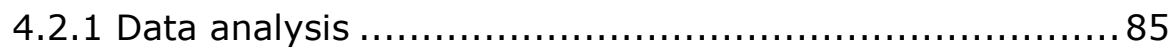

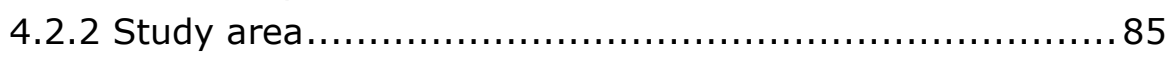

4.3 Results ........................................................... 85

4.3.1 Local processes of resolving land rights and tenure challenges..................................................... 85

4.3.2 Minimising the challenges of changing customary tenure

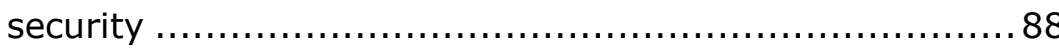

4.4 Local perception of food security and land rights changes ......91 
4.5 Discussion

4.6 Conclusion and policy recommendations..........................94

Chapter 5 Designing responsible and fit-for-purpose (FFP) customary land rights and tenure model for food security of smallholder farmers

in northwest Ghana.

5.1 Introduction ........................................................ 98

5.2 Literature review .............................................. 99

5.2.1 General requirements for modelling and tenure security 100

5.2 .2 Designing a food security model .......................... 102

5.2.3 Designing land rights and tenure model.................. 102

5.2.4 Food security manifestations and dimensions ............... 103

5.1 Methodology .......................................................... 105

5.4 Results........................................................ 107

5.4.1 Designing, modifying and adapting an appropriate model

107

5.4.2 User requirements for designing a model ................ 110

5.4 .3 Adapting from other models............................. 114

5.4 .4 The New model ...................................... 115

5.4.4.1 How the new fit-for-purpose model will operate......... 116

5.5 Discussion of results ........................................... 117

5.5.1 Choosing an appropriate model ............................ 119

5.5.2 User requirements for designing a land rights/tenure model

........................................................... 119

5.5 .3 Adapting from other models.............................. 120

5.6 Conclusion and policy recommendations....................... 121 Chapter 6 Testing a fit-for-purpose (FFP) model for strengthening customary land rights and tenure to improve food security in

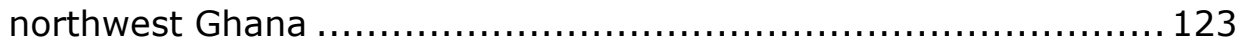

6.1 Introduction ................................................... 124

6.1.1 Debates surrounding use of models for securing tenure. 124

6.1 .2 Effectiveness of the models............................ 126

6.1 .3 Functioning of the models.............................. 126

6.1 Obstructions to the effectiveness of models ................... 126

6.2.2 Land and farming arrangements in the study area ........ 127

6.3 Methods ......................................................... 129

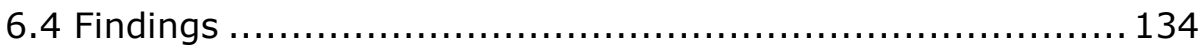

6.4.1 Effectiveness of new model ............................... 134

6.4.2 Functioning of the new model ............................. 137

6.4.3 Possible obstructions to effectiveness of new model ...... 140

6.4.4 Testing the model......................................... 142 
6.5 Discussions....................................................... 143

6.5.1 Effectiveness of new model .............................. 144

6.5.2 Functioning of the new model ............................. 145

6.5.3 Possible obstructions to effectiveness of new model ...... 146

6.6 Conclusion and policy recommendations........................ 147

Chapter 7 Synthesis ..................................................... 149

7.1 Introduction...................................................... 150

7.2 Main Findings................................................. 151

7.2.1 To assess the changing customary land rights and tenure security inequalities among subsistence farmers in northwest Ghana

7.2.1.1 To assess the implications of customary land rights and tenure security inequalities of subsistence farmers for food security in northwest Ghana....

7.2.2 To ascertain how challenges of changing customary tenure and service arrangements of subsistence settler farmers can be tackled to improve land rights, tenure security and food security

7.2.3 To design a fit-for-purpose model that can improve land rights \& land tenure security leading to food security of subsistence/smallholder farmers in northwest Ghana .... 153

7.2.4 To mock-test the implementation of the new fit-for-purpose model towards improving land rights \& land tenure security of subsistence farmers to promote farming, food availability and food security ............................................ 155

7.3 Implications of the research results ........................... 155

7.3.1 For literature.......................................... 156

7.3.2 Public or social policy issues.............................. 156

7.3.3 General community development and social cohesion ... 156

7.4 Validity and Reliability of the Research: Generalisability, ethical considerations and expected impact on theory, policy and practice

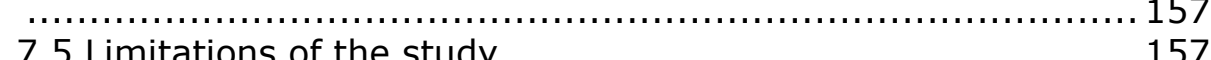

7.6 Future research prospects ....................................... 157

Bibliography Bibliography ......................................... 159

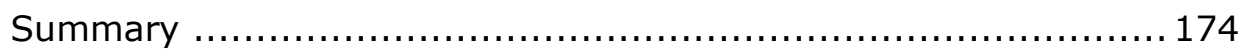

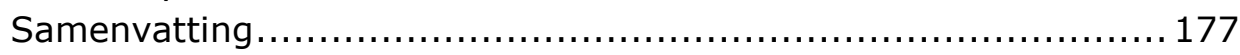

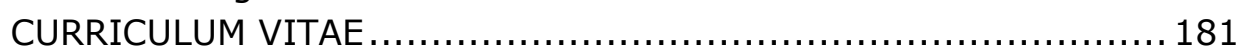




\section{List of figures}

Figure 1 Conceptual framework

Figure 2 Land tenure security \& food security Model adopted from Mulolwa (2002) .15

Figure 3 Case study area .17

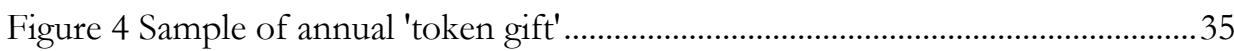

Figure 5 Levels of groups' land rights \& tenure security in study area .......................38

Figure 6 Temporal changes of farm sizes in rural setting.Source: Fieldwork, (2019).

Figure 7 Temporal urban farm size changes. Source: Fieldwork, (2019). .................42

Figure 8 Urban settlement 2006 ................................................................................

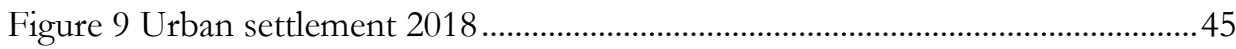

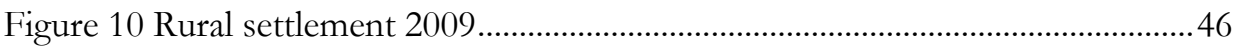

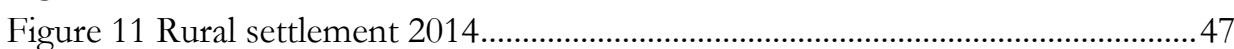

Figure 12 Range of customary land rights \& degree of tenure security in study area.

Source: fieldwork, (2019) and adapted from Lemmen et al., (2015)..........................48

Figure 13 Changing peri urban farm sizes ..................................................................69

Figure 14 Changing rural farm sizes .......................................................................

Figure 15 Annual household food availability ...........................................................

Figure 16 Local procedure for settling customary tenure challenges. (Author's

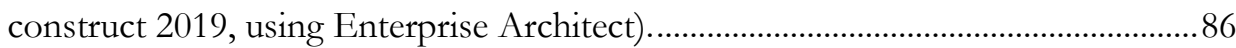

Figure 17 Trend of rural farm size variations. (Author's construct 2019)................87

Figure 18 Trend of urban farm size variations. (Author's construct, 2019)..............88

Figure 19 Building development versus land availability 2006 (Adapted from Google Earth Pro)

Figure 20 Building development versus land availability 2018 (Adapted from Google Earth Pro) …………………………………………………………........ 91

Figure 21 Monthly trend of food availability. (Author's construct, 2019)................92 Figure 22 Current customary land rights model in study area. Adopted from Nara et al (Nara et al., 2020b)

Figure 23 Responsible \& fit-for-purpose land rights \& land tenure model.

(Author's construct, 2020)

Figure 24 Current land rights \& land tenure model in study area. (Source: Nara et al., 2020b)

Figure 25 Model-testing flow chart Author's construct based on fieldwork, (2020) 
Figure 26 Responsible \& fit-for-purpose customary land rights \& land tenure model. Adapted from Nara et al., (2020b)

Figure 27 Mock-testing communities' trust in model's feasibility. Author's construct from fieldwork (2021) 


\section{List of tables}

Table 1 Selected districts and Communities (*disputed) ...........................................19

Table 2 Landowner FGD participation ...................................................................... 31

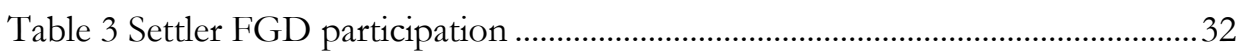

Table 4 Community land rights $\&$ tenure arrangements ...............................................36

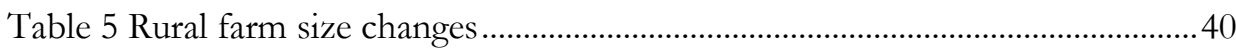

Table 6 Trend of urban farm size changes................Error! Bookmark not defined.

Table 7 FGD participants - Sing, Piina no. 1 \& Nimoro .............................................65

Table 8 FGD participants - Kunfabiala, Piina no. 2 \& Fielmua …………………….....65

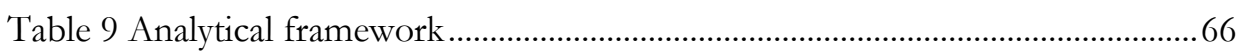



Chapter 1 Introduction 
The need to achieve global food security has been emphasised time and again as fundamental for survival and for living an active and healthy life. This need is largely supported by all as championed by the UN and requires a multifaceted approach to succeed. One of these approaches is strengthening land rights of smallholder and subsistence farmers in Sub-Saharan Africa's northwest Ghana. In Sub-Saharan Africa and Ghana specifically, migrants constitute - in substantial part - the subsistence farmers population. In fact, the term 'settlers' in Ghana, refers to migrants 'permanently' living in a community other than where they originally hail from. The people of the Upper West region do migrate for many different reasons - economic, social, political or environmental but notably due to land resource inadequacy against its growing population (Abdul-Korah and Gariba, 2007, 2008; Mennonite Economic Development Associates (MEDA) Ghana, 2012; Songsore, 2009). The scarcity of agricultural land in some locations culminating in tenure uncertainties with its resultant low agricultural production mainly make affected farmers move to regions they envisage to provide them with some respite (Mennonite Economic Development Associates (MEDA Ghana, 2012). For others, the absence of peaceful co-existence due to insecurity of tenure, denigration and direct physical attempts to dispossess and actual dispossession by some members of the same clan/family is a provocation for people to relocate. Besides, there are other reasons of conflict, famine or other natural disasters that compel people all over the world to move and become strangers, migrants, refugees and maybe ultimately settlers in places other than their place of origin (International Organisation for Migration, 2018). Furthermore, migrants were often sought to help populate a village and cultivate land in subSaharan Africa when land was abundant in the past (Cotula et al 2004). Customary chiefs as well as their subjects wanted more people settled under their control as a source of military, political and economic power similar to medieval Europe. Migrants usually found a landlord or patron member of the allodial landowning group who initially lodged them and gave them access to land. Many of these customary tenure arrangements provided adequate security because once allocated to families or households land rights, until recently, are rarely revoked by customary custodians (Kasanga \& Kotey, 2001; Place, 2009; Platteau, 1996). Under such arrangements, land tenure was secure. However, more recently, these no longer seem to function in the same way. Learning how and why there are issues leading to land tenure and thus food insecurity and, co-creating an intervention to tackle those will be the focus of this thesis.

In Ghana, irrespective of how long a group of people may have lived with an earlier group, the "settler" status of all later-comers remains permanent. As per Ghanaian oral tradition and customary law documented by Ollennu, (1962) and Da Rocha and Loddoh, (1999), customary agreements once entered into are perpetual in nature except in rare instances of gross violation of the agreement or in the absence of an heir. The phenomenon follows the end of tribal or ethnic invasions, conquests and occupation. The settlers, referred to as 'saamba' in particular localities entered into an agreement of a sort with the group they met already occupying the land (i.e. early comers known as tendeme, tendamba or singular - tendaana). For such settlers in Ghana, there is almost no intention of moving back to where they came from and so they 
have become permanently settled in the current location because they may have lost their root, identity or recognition in the original location before the movement. Settlers therefore revere their landlords as generous providers of what they lost in their place of origin - land.

This research touches on the intra-regional migration in northwest Ghana where the settlers came in hundreds of years ago. The settler elders narrate (corroborated by the indigenes and land owners) that due to the insufficiency of land in their place of origin, their ancestors moved in search of available land. When they observed vast unoccupied lands in their current location, they looked for and entered into an agreement under oral tradition with the land owners. This gave them the right to occupy, settle and cultivate the lands. Their rights include transfer to their heirs and others by informing the landlord. They also had almost unlimited boundaries except that they were shown the directions which their activities should follow depending on the community concerned. As part of such agreements and in accordance with customary practice, norms and laws in Ghana the occupation, use and transfer rights (except sale) that they were given subsist in perpetuity subject to "renewal of some sort". In return, the strangers were required to perform annual rites and/or render some services to their landlords either on request or when settlers desired. This was meant to show the settler's recognition of the landowner's ownership of the parcel on which he (the settler) has settled. There was no economic benefit or commercialisation of the agreement on land at the time but rather everything they did was centred on a moral obligation or social justice from both sides as required and demanded by traditional practice and custom.

This has been the practice even till today conveyed in oral tradition and later in documentations as indicated earlier by land scholars with deep insight on land and custom either as chiefs or coming from chiefly royal and landowning backgrounds. Since change is inevitable, internal dynamics within the customary setting brought about some changes in the customary tenure and service arrangements. That is, stipulated non-cash services or rewards provided to landowners for giving out land to other people, but with insignificant disturbance to the original agreement and the general wellbeing of both groups. For instance, anytime it became obvious that the landowner's family size had increased beyond the capacity of their current landholding, custom allows him to appeal to the settler for labour support or a portion of the settler's land which he will normally gracefully share. It is uncustomary and almost impossible for any of them to act in a manner that displeases the other since dire consequences accompanied such misbehaviour. The worst of it being that the offender got an 'invitation to the ancestry' to answer for going contrary to the initial agreement by the ancestors. After all, land is believed to belong to a great multitude of people some of whom are dead, others still living and those yet to be born (Ollennu, 1962; Da Rocha and Loddoh, 1999). However, with the influence of external factors like population growth due to rural-urban migration and urbanisation settler land rights are fast diminishing, livelihoods are threatened, household food insecurity is common, mutual respect and peaceful co-existence are becoming an illusion (Dembitzer, 2014; Chauveau, Cisse, Colin, Cotula, Delville, Neves, Quan, Toulmin, 2006). This leads to 
growing challenges of land access causing food insecurity for those directly affected, and beyond. Striking a balance between traditional land tenure arrangements and the emerging way of living influenced by all those external factors has not been adequately embedded in northwest Ghana. Doing so by co-creating a model by combining tradition and modernity with strong input from the diverse local communities is what this research will work on.

To understand the traditional land tenure arrangements, we need to look at the mechanisms of traditional land allocations made to persons willing to use the land for especially agricultural and settlement purposes. Customary tenure arrangements are always accompanied by some 'services' to renew the legitimacy of the landholding. Regarding non-indigenes, Cotula, Toulmin, Hesse, \& et al., (2004) indicate that when land was abundant in the past, migrants were often sought to help populate a village and cultivate land. These authors further indicate that in those times, customary chiefs in Africa viewed people settled under their control as a source of military, political and economic power. Migrants usually found a member of the allodial land owning group who initially lodged them, gave them access to land and acted as the intermediary between them and the landowning group/society. In return, the migrant was expected to provide some economic reward or service of a sort in the form of labour on the landlord's farm. Labour services are either at landlord's request or initiated by the migrant/settler. The provision of stipulated or unspecified quantity of farm produce to the landlord also forms part of the services to renew the landlord-settler relationship. Overall, these service arrangements usually used to lack any emphasis on economic benefit in some communities. The granting of rights to migrants/settlers does not extinguish earlier rights per se, hence these service arrangements. Rather, there is a continuum of rights (i.e. coexistence of multiple forms of land rights) on the same land (Lemmen, 2013; Quan \& Geoffrey, 2008). Many of these customary tenure arrangements provide adequate land tenure security because once allocated to families or households, land rights are rarely revoked by customary custodians (Kasanga \& Kotey, 2001; Place, 2009; Platteau, 1996). Customary tenure arrangements therefore seemed capable of securing land rights. But later evidence in this research suggests the need for some formalisation (for instance, backed by the Land Act 2020, Act 1036 and others) to check abuses (from especially landowners). This is particularly because access to land and its tenure security are quite unequal among different groups. These have varying levels of undesirable implications needing redress.

This 'land tenure security' is the protection that land holders have against involuntary removal from the land they hold (Almeida \& Wassel, 2016; Boudreaux \& Sacks, 2009). It is also the perception that landholding is secure within the stipulated duration of the tenure (Bugri, 2008). Land tenure is important in determining its security (Nguyen, 2014; Zevenbergen, 2002a). While protection comes from higher authority (in this case customary or state), perception originates from the people in the community based on their trust for the system (Boudreaux \& Sacks, 2009). Both protection and perception are important tenure security indicators that influence what production decisions people can make. Access to secure land is widely accepted as a precondition for access to other services and livelihood opportunities such as farming for 
most people in sub-Saharan Africa (Payne, 2004). In this study context, landowners more than anything or anyone else want to 'solely' control these changes. This is being resisted in preference for the existing model backed by legislation etc. and this is where the FFP model comes in handy.

A complexity of tenure systems exists in most of the developing world but the bottom line of each of them is its degree of security and its influence on livelihoods (Payne, 2004). Tenure security in the form of formal legal, customary or religious land rights, could provide more predictability and secure access to fundamental rights including for food and housing (Wickeri and Kalhan, 2010). Cotula, Toulmin, \& Hesse (2004) suggest that the state (through protection) should legitimise land rights by validation which implies some documentation. But Zevenbergen et al., (2013) believe that registration alone does not secure tenure. De Soto equates land tenure security to recognition of existing rights by means of formalising which also suggests documentation (Brasselle, Gaspart, \& Platteau, 2002). However, one review by Lawry et al., (2014) questions the impact of formalising customary land rights on investments, especially in sub-Saharan Africa. Another review found that in four sub-Saharan African countries, neither titled tenure nor land transfer rights affected farm productivity (Ruerd \& Policy and Operations Evaluation Department (IOB) Ministry of Foreign Affairs, 2011). Also, Almeida \& Wassel (2016) found that in Timor-Leste, "the current law 1/2003" does not provide legal rights for those without any documentation yet most of the respondents still consider their tenure as secure even as they lack any documentary proof. For Lund (2000); Simbizi (2016) land tenure security exists when 'an individual perceives that $\mathrm{s} /$ he has the right to a piece of land on a continuous basis. And if it is free from imposition or interference from outside sources. And finally, the ability to reap the benefits of labour and capital invested in that land either in use or upon transfer to another holder. Bugri (2008) agrees to this when he found out that $80 \%$ of his sample with no registered title felt that their land was secure. Then Obeng-Odoom (2012) clarifies that it is the perception of secure tenure that matters but not necessarily a formal legal mechanism of security. Customary land law is noted to historically offer the best security of tenure to individuals, families and local communities (Akrofi \& Whittal, 2011).

Therefore, tenure can be said to be secure whether it is made legal, de facto or perceived once there is recognition of one's land rights for a given undisturbed period which is long enough to support investment and recoup of the benefits (Christine, Simbizi, Zevenbergen, \& Bennett, 2015; Nguyen, 2014; Van Gelder \& Luciano, 2015). It therefore means that if expropriation must take place anytime within the tenure duration, then it must result in consultation with and negotiation for commensurate compensation. And this must be handled in a humane and dignifying manner recognised by law. The tenets of tenure security opined by Boudreaux and Sacks include protection by government against forcible eviction and deprivation of other tenure rights (Boudreaux \& Sacks, 2009). Payne (2004) note the need to classify tenure types to facilitate a critical scrutiny on how many different types are available to take care of different social groups in a given region. Payne broadly classified tenure (under formal and non-formal/unauthorised/semi-legal) to assess their influence on housing for the urban poor. In addition to these, United Nations 
Settlement Programme (2004) also identifies Islamic and customary tenure types/categories from which individual and smaller group tenures are derived. Customary tenure is fundamental to this research. Also, it is much easier to assess the rights of different categories of people within a specific tenure type than across different ones. Hence, the choice to focus on only customary tenure arrangements of subsistence farmers in northwest Ghana since information on these issues in that region in the literature seems scanty.

Payne, Durand-lasserve (2012); Payne (2004) posited that land for urban housing is obtainable from one or a combination of different types of land rights or tenure. Land for farming (including for subsistence) purposes is largely provided by the customary system in many parts of sub-Saharan Africa (Dembitzer, 2014). Napoli, de Muro, \& Mazziota (2015) state that the combined contribution of smallholder and subsistence farmers to global food security is very significant. Payne (2004) noted that it is theoretically possible to have a high degree of tenure security but constrained rights or a lower level of security and a higher level of rights. In the work of du Plessis Jean, GLTN, UN-HABITAT, Augustinus, Barry, Lemmen (2016); Lemmen (2013); Payne, Durand-lasserve (2012); Van Gelder \& Luciano (2015), various land tenure rights have been identified. The continuum of land rights by du Plessis Jean, GLTN, UN-HABITAT, Augustinus, Barry, Lemmen (2016), where various land rights subsist on a single piece of land is adapted in this research to reveal the existing customary land rights in the region.

Cotula et al., (2004) observe that indigenous inhabitants in sub-Saharan Africa rely on the principle "by which migrants may not obtain full rights" over land. They therefore, will always depend on their patrons for their secondary land rights, even where they have been farming the land for generations. And further noted that migrants by contrast, presume that they should acquire full rights over land, having cultivated a plot for a certain length of time." Based on the above contentions, subsistence tenure insecurity is said to be real and problematic in Africa. Yet, International Fund for Agricultural Development (IFAD, 2015) shows that there is a potential for subsistence farmers (including settlers) to contribute to increases in agricultural production. Such increased production would contribute to improving at least, one of the dimensions of food security.

\subsection{Food Security: Perception and dimensions}

The perception of the people and how they interpret their experiences of food security in relation to widely accepted definitions is critical in understanding its severity and how to solve it. For instance, how similar or different is the respondents' interpretation of food security defined by the United Nations. That is a situation when "all people, at all times, have physical, social and economic access to sufficient, safe and nutritious food that meets their dietary needs and food preferences for an active and healthy life" (Biederlack and Rivers, 2009). The potential of subsistence farming to boost food security is repeatedly emphasised. FAO (2015) has established that growth in family (subsistence) farming has significant positive effects on the livelihoods of the poor through increases in food availability and incomes. 
The Economic Commission for Africa (AEC (2004)) explains that food security is the capacity of households, communities and the state to mobilize sufficient food through production, acquisition and distribution, on a sustainable basis. For that matter, people are considered food secure when they have available and adequate access throughout the year in a sustained manner (Ballard, Kepple, \& Cafiero, 2013). According to FAO et al. (2015), factors that enable progress towards food security and nutrition goals are agricultural productivity growth, markets and social protection. The food needed in the world to boost global food security comes from both modern large scale commercial and small-scale agricultural activities and through the market (Federal Ministry of Food and Agriculture (BMLE, 2015). But household food supply is mainly obtained through own production. In addition, people make purchases from the market and whenever it is possible, they receive food aid as well to augment. The factors influencing household food supply are availability, accessibility utilisation and stability (Cotula \& Mathieu, 2008; Elliot \& WFP, 2012; Holden \& Ghebru, 2016). The views on perception and especially the main sources of food supply and security in the literature all point to availability and accessibility (i.e. through own production and market), which form part of the main focus of this research. Capone, El Bilali, Debs, Cardone \& Driouech (2014) distinguish four aspects of food security: food availability, accessibility, utilisation and stability (more on which follows in chapters $2-6$ ).

As land tenure security has significant implications for subsistence agriculture (Cotula et al., 2004), people without access or with very limited access to such natural resources as land are vulnerable because they have difficulty in obtaining food (Chauveau, Cissé, Colin, Cotula, Delville, Neves \& Quan, 2007; Food and Agriculture Organization, 2002; Ruerd \& Policy and Operations Evaluation Department (IOB) Ministry of Foreign Affairs, 2011). AEC (2004) observes that the most predominant livelihood activity for many people in Africa is subsistence farming. Therefore, unequal access to land and insecure land tenure have effects on their livelihoods (AEC, 2004). And so, securing tenure rights for vulnerable groups is important in many ways including maintaining household food supply and ultimately ensuring food security. How to come up with an embedded way to secure access to land for northwest Ghana's settlers, smallholder and subsistence farmers is key in this research.

\subsection{Knowledge Gap}

Studies by Lawry et al., (2014) reveal that secure and predictable access to land is important in improving the livelihoods of millions of farmers around the world through increased agricultural production and food security. Lawry et al., (2014) further indicate that interventions in this direction mostly emphasise largescale farmers but tend to neglect the plight of small scale farmers (some of whom are settlers who do not possess their own land). Akrofi (2013) found that land access and security for all uses in peri urban southern Ghana is skewed against women. Another research by Naab et al., (2013) assesses the impact of rapid urbanisation on agricultural lands and found negative implications on poor farming communities in peri urban Tamale in the northern region of Ghana. Asiama et al, (2017) have indicated that in Sub-Saharan Africa's customary lands, the use of mechanised farming technology and 
intensive farming techniques have largely failed to increase food productivity in spite of foreign investment and the interest of the farmers to do so. Implicit in this is the fact that the panacea for sustained increase in food production in the sub-region has not yet been found. Additionally, smallholder farmers contribute up to $80 \%$ of food consumed in a large part of the developing world (AEC, 2004) and only $40 \%$ of global farming acreage is farmed commercially (Federal Ministry of Food and Agriculture (BMLE, 2015). There is therefore the need for targeted research at assessing smallholder food production potentials in relation to tenure security to complement commercial production. It is worth noting that customary lands constitute up to $80 \%$ of all lands in Ghana. There are studies (not in Ghana) about the need for access to land with secure tenure in Ethiopia, Mozambique, Moldova, Asia and the Pacific regions that highlight the potential of smallholder farmers in contributing to increased agricultural production (Gebrehiwot, 2012; Group, 2016; IFAD, 2009; Learch, 2016).

In all these works, not much attention is given to improving land rights and security of tenure for subsistence (smallholder) farmers who according to (Ministry of Food and Agriculture, 2011; Republic of Ghana, 2012, 2014) form a chunk of the poor in both rural and peri urban areas in Ghana. Meanwhile Zevenbergen et al., (2013) found that many land registration and formalisation intervention processes do not seem to favour the poor. Also, Chauvin et al., (2012) recommend deep agricultural transformation towards food security but there is not much research targeting only smallholder or subsistence farmers, especially settlers. Most of them have different tenure arrangements that tend to influence their production and investment decisions with consequences for food security. This research's contribution to literature is to show a way to strengthen customary land rights and give more secure land tenure to boost the efforts of subsistence and help smallholder farmers augment global food security. This can possibly be achieved through strong engagement with the local people to co-create a land rights and land tenure model that is fit-forpurpose and based on user requirements at no or very little cost to the people and the state. Mennonite Economic Development Associates (MEDA) Ghana, (2012) emphasised that stronger land rights and more secure land tenure will enable smallholder farmers - including migrant farmers - to make productive investment decisions thereby increasing food production and contributing to food security.

\subsection{The Research Problem, Objectives and Questions}

\subsubsection{Statement of the problem}

The problem is that the current food security strategies of concentrating more on commercial production and distributing through market avenues and food aid needs to be augmented as many hungry people have not yet been reached (FAO IFAD UNICEF, 2017). Meanwhile, minimal-cost-interventions are needed by farmers to produce at least enough for their households for their food security. Also, recent interventions to secure tenure are equally not effective enough as the current approach is deemed too expensive for the poor as little 
attention is paid to the negative implications of replicating western based models in sub-Saharan Africa. This means that the question on what tenure strategies will work for such farmers remains unanswered. This research is justified by its equal concentration on all categories of farmers. The strategy has the double benefit of empowering more poor people in food production through secure tenure thereby minimising the challenges of speedily distributing food to all needy areas. This is done by co-creating the design of a land rights and land tenure model that addresses the identified tenure problems to encourage "new" investments for increased food production. This is especially worthwhile as many poor households consume a large proportion of the food from their own farms (Federal Ministry of Food and Agriculture (BMLE), 2015; Republic of Ghana, 2014). Subsistence is variously referred to as smallholder, small scale, family or peasant farming while settlers are referred to as non-indigenes, strangers, non-autochthons, migrants or nonnatives. For the purpose of this research, the term 'subsistence' is used interchangeably with smallholder while 'settler' is used for non-indigene. The choice to use subsistence settler farmers reflects how this group of farmers is generally known in the study area in Ghana.

The problem identified in this research revolves around weak institutional control measures and poor enforcement of tenure laws giving rise to tenure uncertainty among the predominantly agrarian subsistence (settler) farmers.

\subsubsection{Research objectives and Questions}

The overarching research objective is to examine customary land tenure arrangements and co-create a land tenure model for improving tenure security of subsistence farmers in order to enhance their contribution to global food production and food security.

\section{Sub-objectives and research questions}

1. To assess the changing customary land rights and tenure security inequalities and implications for food security of subsistence farmers in the region.

a) What customary tenure and service arrangements exist for subsistence indigene and settler farmers in the region?

b) What are the socio-cultural and spatio-temporal change trends and challenges of customary tenure and service arrangements of subsistence indigene and settler farmers?

c) What are the implications of these changes on food production and food security of the various categories of subsistence farmers?

2. To ascertain how the challenges of changing customary tenure and service arrangements of subsistence farmers can be tackled to strengthen land rights, improve tenure security and food security. 
a) How can the influence of changes in customary tenure and service arrangements on landholdings of subsistence farmers be tackled to safeguard tenure security?

b) How can the challenges of changing customary tenure and service arrangements be minimised?

c) How do subsistence farmers perceive food security and how can changes in customary tenure and service arrangements positively influence food production and food security?

3. To co-create a land rights and land tenure model that can improve tenure security leading to food security of subsistence farmers in the region.

a) What kind of model is most appropriate for securing tenure and promoting food production by subsistence farmers under customary system in the region?

b) What general considerations are needed in designing an appropriate model that assures tenure security of subsistence or smallholder farmers?

c) What aspects of the current land tenure and service arrangement in the region should be included in the new model to secure subsistence farmers' tenure and facilitate their contribution to food security?

4. To mock-test (i.e. validate) the implementation of the new model towards improving tenure security of subsistence farmers to contribute to food production and food security.

a) What is needed for the new model to work effectively to secure tenure and food supply?

b) How will the new model function to ensure that tenure is secure and food supply sustainable?

c) What can possibly obstruct the effective functioning of the new model which may negatively affect food production, supply and food security?

\subsection{Conceptual Framework}

This conceptual framework attempts to depict the current situation on the ground relating to the phenomenon being explored in this research. Its starting point is drawn from existing literature on changing tenures among farmers which suggests that there are external factors influencing the internal factors that in turn influence changes in customary tenure and service arrangements in sub-Saharan Africa (Arko-Adjei, Jong, Zevenbergen, \& Tuladhar, 2009; Chauveau, Cissé, Colin, Cotula, Delville, Neves, Quan, 2007; Dembitzer, 2014). 


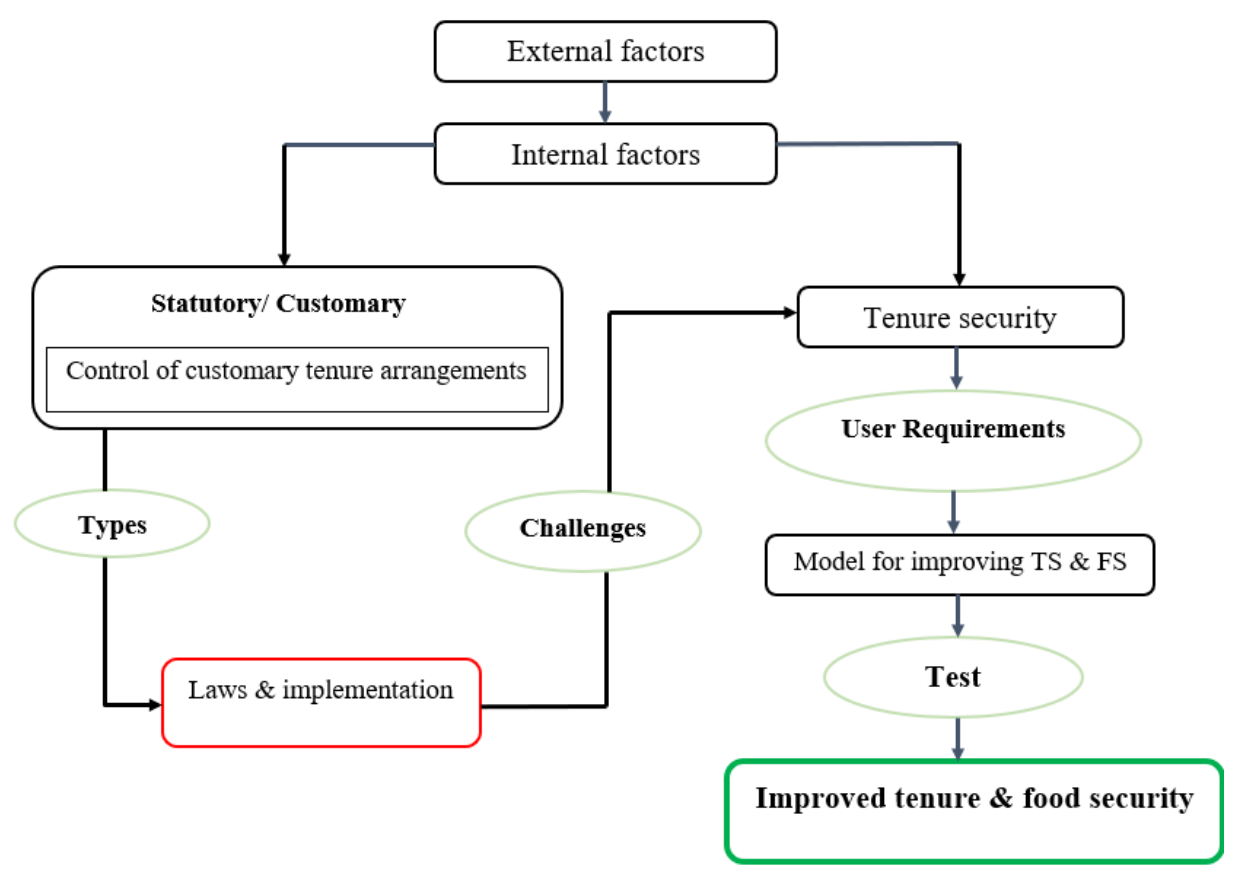

Figure 1 Conceptual framework

This framework contends that urbanisation and rapid population growth are not exhaustive in explaining land rights inequalities and land tenure insecurity in the study area. Population growth and urbanisation are inevitably part of the growth process of societies anywhere in the world. Some unknown factors within the customary system seem to be responsible for customary tenure transformation and subsequent tenure insecurity in sub-Saharan Africa. This may be the control aspect on clarity, adequacy or appropriateness of laws or their implementation. The kind of control exercised, depends on the tenure type that sub-objective 1 seeks to describe. The control which manifests in the provision and implementation of laws reveal inherent challenges that subobjective 2 tries to resolve, which in turn influences tenure as secure or not. Based on the challenges affecting tenure security, users suggest alternative strategies (i.e. user requirements) which are used to co-create and design a model in sub-objective 3 for improving tenure, possibly leading to food security. But only after the model is verified or mock-tested (in sub-objective 4) for appropriateness, then it can be assumed its success supports the improvement of tenure and consequently food production and food security.

This is the rationale of this research investigation to offer advice on policy and practice based on empirical evidence. The first sub-objective identifies the 
tenure differences between subsistence indigene and settler farmers; be they men, women, disabled or youth. This first objective reveals the nature and extent of land rights and tenure security variations and inequalities. Then the consequent challenges and implications for farming investment leading to food production, its availability and food security are looked into. The second subobjective obtains user requirements on resolving the challenges identified in sub-objective 1 . The third sub-objective attempts addressing the challenges by co-creating a new fit-for-purpose (FFP) model with local people based on user requirements and learning from related models contained in literature. The fourth sub-objective validates (mock-tests) the new model's feasibility based on feedback from the beneficiaries (i.e. users) for improving tenure and subsequently improving food security. See Figure 1.

\subsection{Research Design}

The research design refers to the overall strategy chosen to integrate the different components of the study in a coherent and logical way to ensure that the research problem is effectively addressed (Yin, 2003). Based on the overall objective of this research, which is to provide what Burge (2015) describes as "a pragmatic path" to address tenure and food insecurity, the Soft Systems Methodology (SSM) is chosen. SSM designed by Checkland \& Wilson in the 1970 s is a systems approach that is used for analysis and problem solving in "complex and messy situations". Additionally, the SSM allows for the use of multiple research methods at different stages for example, different methods for each objective of this research. The SSM is also adopted because of its participatory and interdependent nature, using "systems thinking" in a cycle of action research, learning and reflection to help understand the various perceptions that exist in the minds of different people involved in the situation (Checkland \& Poulter, 2010; Maqsood, Finegan, \& Walker, 2009). That is, a "learning paradigm where it has the starting point in unstructured problems within social activity systems in which there is felt to be an ill-defined problem situation" (Simonsen, 1994). SSM is also receptive to the use of case study approach in data collection (Maqsood et al., 2009). SSM in this research aims at using the systems approach or model, which according to Boudreaux \& Sacks (2009) responds to citizen demands. Therefore, the approach here is for more secure land tenure as a means of farming to produce more food. Also, in the case of this research, varied understanding from landlords and subsistence settler farmers with varied perceptions about the situation of customary tenure security fits in SSM. Hence Maqsood et al., (2009); Simonsen (1994) explain that SSM is an approach which in a systematic way tries to establish and structure a debate concerning actions for improving the problematic situation - as in improving tenure security. They add that "SSM deals with two kinds of activity, 'real-world' activities involving people in the problem situation and 'systems thinking' activities where the analyst (in some way) tries to abstract from the real world and doing his systems thinking where people from the problem situation may or may not participate."

The SSM further fits in this research since in a legal pluralistic environment like Ghana, customary tenure arrangements are increasingly becoming more complex and "difficult to manage"(Maqsood et al., 2009). The SSM is further preferred as it comprises of various steps of inquiry processes of problem 
identification, diagnosis and possible solutions. It is also because of its suitability for phenomena that require understanding of human relationships or interpretations of environment and policy. That is, a situation with obscure goals and/or conflicting goals and susceptible to or involving multiple variables. These phenomena can be influenced by temporal and historical factors viewed and interpreted differently (Burge, 2015). All these apply to the customary land rights/tenure and service arrangements that this research examines. Furthermore, Checkland \& Scholes in 1990 posited that SSM enables designing changes which are both systematically desirable and culturally feasible among involved stakeholders (Lamont, 1994). Seven phases of SSM exist, they are 1) Problem situation unstructured 2) Problem situation expressed 3) Root definitions of relevant systems 4) Conceptual models 5) Comparison of conceptual models with the real world 6) Feasible changes and 7) Actions for improvements. The choice of this methodology is its suitability for this research which deals with a socio-cultural system to design solutions that are culturally acceptable and socially beneficial. Phases 1 and 2 of the SSM captures objectives 1 and 2 while phases 3, 4 and 5 of SSM addresses objective 3 then phases 6 and 7 is utilised by objective 4 of this research.

\subsubsection{Models of land tenure and food security}

Land tenure security is "effective protection by governments against forced eviction" therefore, weak protection may cause its insecurity (Boudreaux \& Sacks, 2009). Yet, land remains an important asset for food production, availability and food security (Lawry et al., 2014). However, in order to address both tenure insecurity and food insecurity simultaneously in the research, there is some emphasis on the problematic area identified which has to do with 'control and use' in Mulolwa's (2002) model. This helps locals design or modify a land tenure model to address the protection and enforcement challenges in order to secure tenure and subsequently food security. This research uses the system idea (i.e. SSM) to co-create a model that aims to improve food security using appropriate tenure arrangements and participants. The tenure arrangements (from user requirements) are put forward by the users, i.e. respondents themselves in a framework that is sensitive to a multi-stakeholder socio-cultural background in addition to cues from existing frameworks in literature (Almeida \& Wassel, 2016).

Multiple tenure systems were introduced elsewhere replacing the traditional tenure arrangement which did not result in land tenure security (Mulolwa, 2002). Therefore, "when weaknesses are found in a system, the existing system should not necessarily be replaced or undermined" (Mulolwa, 2002). Rather, some adjustments be made to the existing model to improve it as the people (users) may have been more familiar working with an improved version of that existing system than a completely new one. This local engineering or co-creation idea is based on the socio-cultural, political and economic circumstances of the local people and is also similar to the Grain Approach (Martinez 2017). It is important in this research by fostering a tenure that local people are familiar with by using local customary and statutory institutions and structures. Ballard et al., (2013), have noted that researchers are usually influenced by their backgrounds as economists, agriculturists, nutritionists to 
design models. Such a model may therefore not fit well into other researchers' approach to solving particular problems of society and therefore, requires either an entirely new model or a modified version of another. For this reason, this research adopts the Unified Land Tenure model with few adjustments (Mulolwa, 2002).

The FAO Prevalence of Undernourishment model, though useful in estimating national and regional trends on food security is criticised for its inability to identify who the food insecure are (Ballard et al., 2013). This study area is the most food insecure place in Ghana (FAO et al., 2015). An experience-based design model of severity of food insecurity that relies on people's perceptions and direct responses was adopted. The approach involves a series of questions regarding their access to adequate food (Ballard et al., 2013) and contributes to FAO's assessment of household food insecurity facilitating policy analysis. This approach was useful in assessing the degree of food insecurity after its perception and prevalence were established among FGD participants. Furthermore, the vulnerability to future food security conceptual framework by Lovendal \& Knowles (2006), is more explicit on the dimensions of food security than factors that give rise to it and so not entirely suitable in this research. Here, there is equal emphasis on the prevalence of tenure security and ultimately food security in a land-people-institution interaction. Again, this model by Lovendal and Knowles, speculates that risks and risk management strategies collectively described as "event status" interacts with current food security characteristics to produce outcomes referred to as "expected future food security status". The "risk management actors" represent the regulatory power by various institutions while the "risk type" refer to the tenure insecurity indicated on Mulolwa's tenure security model. These commonalities facilitate a blend of the two models into one land tenure security and food security model in this research. The model implementation is expected to first improve land tenure security and encourage increased farm investment with possible increase in food availability and accessibility improving nutrition and stability for households who largely consume what they produce. 


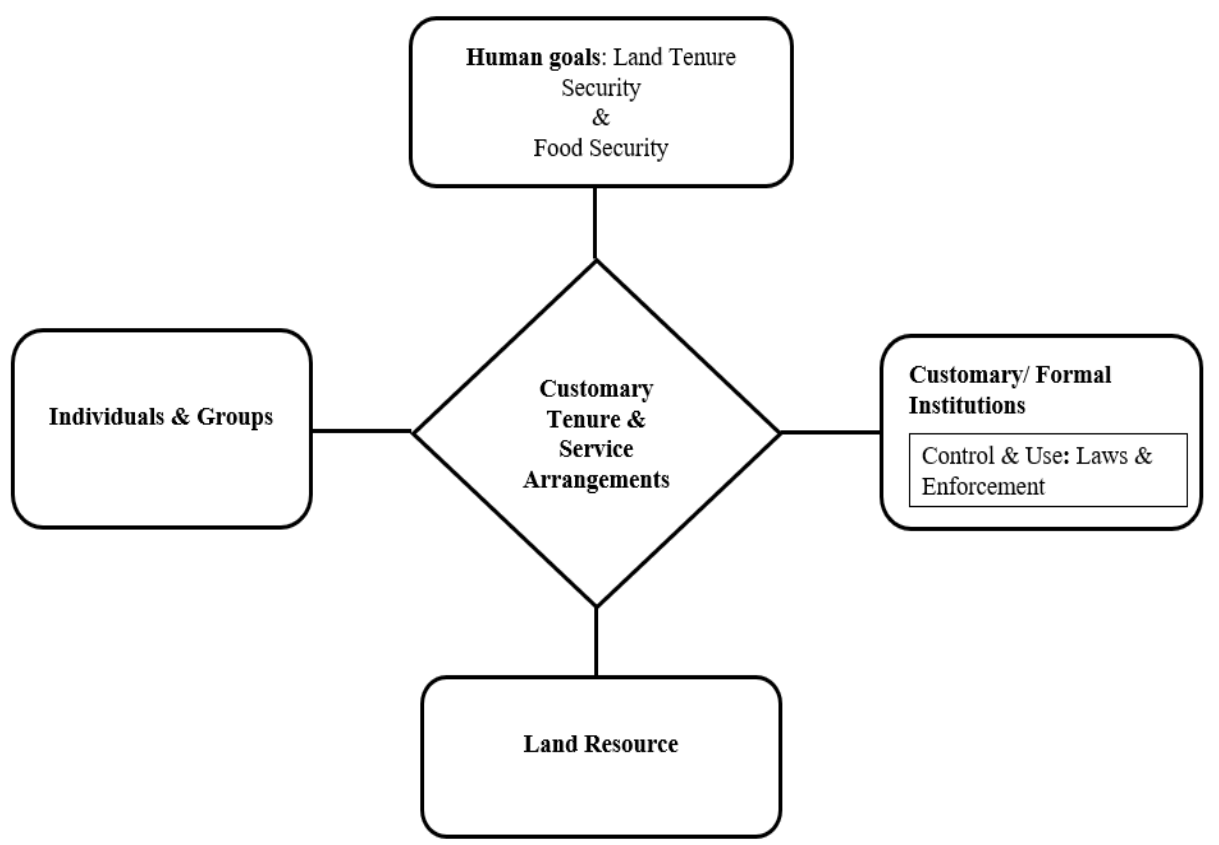

Figure 2 Land tenure security \& food security Model adopted from Mulolwa (2002)

The land tenure and food security model in Figure 2 emphasises the attainment of human goals and aspirations as the ultimate aim. In this research it is customary land rights and tenure security, and food security. In the model, individuals and groups obtain rights and obligations (i.e. customary tenure \& service arrangements) in agricultural land resources. The rights (in the degree of tenure security) are determined based on control and use (which are supervisory and regulatory in nature) by both customary and statutory institutions (i.e. including enforcement of recognised customary tenure laws). This is also suggested by Singirankabo \& Ertsen (2020). And could then lead to the desired human aspiration which in this case is food security, by promoting legal enforcement of all recognised customary land rights held by various categories of people.

\subsubsection{Requirements for an effective model}

The detailed co-created model based on the above model by Mulolwa is to ensure the working at the 'control and use stage.' Its absence may have contributed to the current challenges regarding land rights and land tenure. This can possibly be resolved by empowering already existing but underutilised state law enforcement institutions especially for the sake of the poor either at no or low (socio-culturally) affordable fees (Boudreaux \& Sacks, 2009; Zevenbergen et al., 2013). Next, while information alone is clearly insufficient, it can be a powerful tool in conscientising people to appreciate and tackle their 
land tenure insecurity and consequent food insecurity towards the desired aspiration to resolve in this research (Ballard et al., 2013). For this reason, the media (still under the institutional control) will also be obliged by law to highlight issues of tenure insecurity especially those that constitute infractions on the law. Then legal opportunity is made for those who still prefer the formal court system (control, enforcement \& use) to opt for it with legal assistance from state recognised legal and quasi-legal bodies. Then it is suggested further, that payments by these groups be facilitated by receiving them in kind - in the form of specific measure of farm produce if they so prefer.

With the above in place and certainty of tenure arrangements assured, then it becomes an incentive for increased and sustained investment in farming and food production. There is an assertion that "where tenure was insecure, there was low farm investment in Uganda, Burkina Faso and Malawi" (United States Agency for International Development (USAID, 2016). And added that in these places, "security of women's land rights increased their agricultural investment and production and, improved nutrition outcomes." The result of this, addresses the most critical components of food availability and ready access in qualitative and quantitative terms (Maxwell \& Wiebe, 1999). This could reduce current distribution challenges that FAO is still grappling with as noted elsewhere in this thesis (FAO et al., 2015).

\subsection{Methodological issues}

Throughout this research, the six selected diverse communities gave the inputs needed to answer the different research questions and even co-create the model in the later chapters. Before giving a short overview of the methods used for this, first an introduction of the study area follows.

\subsubsection{Case Study Area and its land tenure forms}

The case study area is in Upper West Region in northern Ghana which covers an area of $18,476 \mathrm{sq}$. km with 702, 110 population (GSS, 2012). A total of $72.3 \%$ of people in the region are into agricultural activities on subsistence basis and many are settlers. For instance, there are several predominantly settler communities including the selected Kunfabiala within peri urban Wa Municipality. There are many more settler communities dotted along the main road connecting Burkina Faso through the region and to southern Ghana (not part of this research). Other settler communities that were covered in this research are more rural Fielmua in the Sissala West and Piina in the LambusieKarni districts with between $80-100 \%$ of the population being settlers. The study area is located in the northwestern corner of Ghana as shown in Figure 3. 


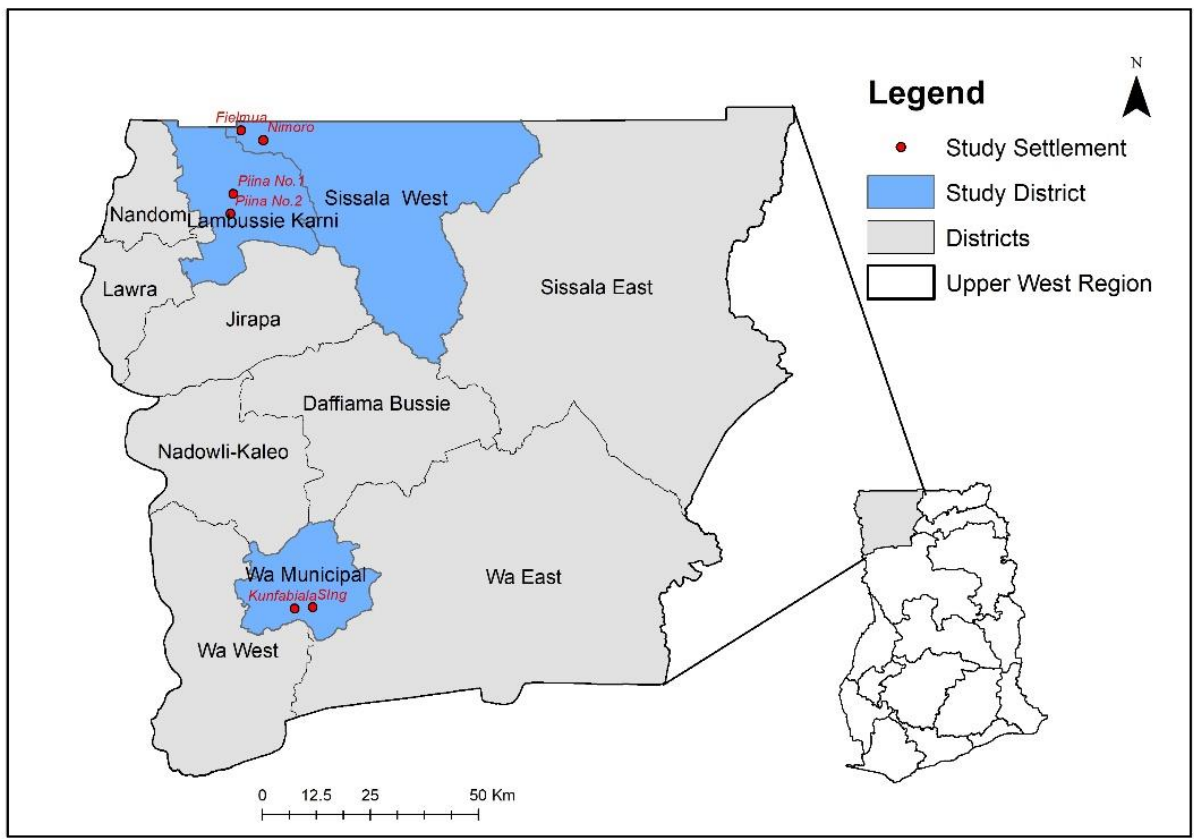

Figure 3 Case study area

While Fielmua experiences intermittent disagreements between settlers and their landlords over issues of land, Piina appears to be relatively peaceful. Thus, both worth investigating to ascertain what transformations are taking place in the rural areas and compare with that of the urban setting. Also, the influencing factors and the likely effects on agricultural investment, food production and food security were examined and conclusions made. This is a region with few ethnic groups controlling most of the lands. Whereas the rest of the ethnic groups are either confined to little parcels of land that barely serve their livelihood needs or they migrate in search of farming/livelihood opportunities. It is for the above reasons that many households with large family sizes migrate and become settlers on other people's land causing the widespread subsistence settler farmer phenomenon in the region and beyond. Land scarcity in some north-western portions of the region has compelled migration to farming areas all over the country but more so within the region. The areas in the Upper West Region (UWR) with vast lands have had to accommodate these migrants as settlers whose tenure is increasingly not secure and as such food security becomes problematic.

Within the customary system, Arko-Adjei (2011) identifies two distinct forms of tenure types in Ghana, spatially defined. The first is based on territorial control of chiefdoms as well as control over land where the land is also held and managed by the stool or skin together with its inhabitants in most parts of southern Ghana. The second, found mostly in upper regions of northern Ghana, is where the land tenure is based on clan/family leanings where land is solely managed by tendamba while the inhabitants are managed by the chiefs. Arko- 
Adjei (2011) further identifies three main interests in customary land in Ghana - allodial/paramount title, customary freehold interest, and tenancy farming rights. The allodial title is the ultimate and highest title in customary land with no superior title to it (Kasanga \& Kotey, 2001). The allodial title is held by groups (a stool/skin, which is the embodiment of people/community or the clan/family led by the tendana). As landowner, the tendana administers the land to both members and non-members of the landowning group. Even chiefs needing land have to refer to the tendana who exercises his discretion based on a kind of 'needs assessment'. Also, as land/earth priest, he (it is always a he) is in charge of performing rituals to maintain the sanctity and prosperity of the land. The tendana is usually the most discerning oldest male and direct descendant of those who first arrived.

The modes of acquiring the paramount title are identified as the clearing of an unoccupied virgin land, followed by uninterrupted settlement for a long time. Others are through conquest and subsequent occupation of the subjugated lands and through a form of alienation such as a gift or purchase from another landowning group (Sinitsina, 2019). Customary freehold or usufructuary interest is held by individual families from the landowning group. In the past, the interest was held by the community member exercising his inherent right to develop and use any vacant virgin communal land. However, as land becomes scarce, members can now only access land from their family or clan lines. Or rarely through re-allocation of land that reverts to the allodial ownership managed by the tendana in this case. Kasanga \& Kotey (2001) indicate that this interest is secure and can also be passed down through generations. The customary landholders can transfer interests freely to any member of the landowning group or stranger even without first informing the tendana because the tendana cannot easily influence the said transfer arrangement. Most customary lands are held in perpetuity except in rare instances of abandonment, forfeiture, or where there is no heir in which case the land reverts to the allodial title holder as opined by Ollennu in 1962 contained in Sinitsina (2019) for re-allocation by the tendana or chief. The tenancy and farming rights are the use rights given to strangers by the allodial or customary freeholder. These rights according to Sinitsina (2019) and Kasanga \& Kotey (2001), once entered into, usually have indefinite duration. While there is annual contribution of farm produce as rent in southern Ghana there seems to be 'acknowledgement to the allodial title holder' in northern Ghana by rendering some labour services or 'a token' of farm produce (ArkoAdjei, 2011; Kasanga \& Kotey, 2001). This could be a source of insecurity in the wake of land scarcity and subsequent land commodification in the study area.

The study area is purposively selected (see Table 1 ) due to the uniqueness of the land tenure arrangements which is permanent in nature as opposed to what pertains in southern Ghana. 
Table 1 Selected districts and Communities (*disputed)

\begin{tabular}{|l|l|l|}
\hline District & Settlement/community & Characteristics \\
\hline Wa Municipal & Sing & Landowners \\
\cline { 2 - 3 } & Kunfabiala & $\begin{array}{l}\text { Settlers (under Sing } \\
\text { landowners) }\end{array}$ \\
\hline $\begin{array}{l}\text { Lambusie- } \\
\text { Karni }\end{array}$ & Piina number (1) & Landowners \\
\cline { 2 - 3 } & Piina number (2) & $\begin{array}{l}\text { Settlers (under Piina number } \\
(1) \text { landowners) }\end{array}$ \\
\hline Sissala West & Nimoro & Landowners \\
\cline { 2 - 3 } & Fielmua & Settlers* and/or landowners* \\
\hline
\end{tabular}

In-depth study was carried out in the largely settler occupied peri urban areas of the regional capital - Wa, where the influence of urban expansion and customary tenure changes and challenges are predominant. The customary lands belong to tendamba with the allodial title of the lands held by clans and families in trust for their members. This area is located in the Guinea Savannah vegetation zone, characterised mostly by large expanses of grasslands with a few scattered trees providing economic needs e.g. food, fuelwood and local building materials. The main occupation in the area as mentioned earlier is subsistence agriculture (Republic of Ghana, 2014). The main crops grown in the area are tubers such as yam and sweet potatoes, cereals such as maize, guinea corn and millet, and legumes such as groundnuts, soya beans and bambara beans. The vegetables grown in the area also on small-scale include okra/okro, pepper, tomatoes and garden eggs while a lot more is imported from Burkina Faso due to shortfalls in local production.

\subsubsection{Methods used}

This is largely a case study research and most of the methods applied can be considered qualitative and included open ended questionnaires, interviews and focus group discussions (FGDs). In addition, a small quantitative element was brought in by combing some national and regional statistics and analyzing some satellite images through visual interpretation.

The use of the case study method is acceptable to SSM mentioned earlier in the research design (in section 1.5). Case study becomes more appropriate when social and community-based problems are being investigated (Burge, 2015; Zainal, 2007). This facilitates gathering of information and views about such situations that are considered to be problematic and therefore shows that there is some scope for improvement (Burge, 2015). The first objective of this research describes the real life socio-cultural and remote reasons for (and challenges of) customary tenure insecurity thus, inequalities. Also, why tenure insecurity seems skewed and more so against subsistence settler and female farmers and, finally how it influences household food security. This is also in line with the view of Yin (2003) recommending case study for descriptive and 
explanatory research objectives. The case study strategy enables a detailed contextual understanding of the relationship between socio-cultural contexts of customary tenure arrangements and food security. The distinct customary tenure and service arrangements of different categories of these farmers is a real-life contemporary socio-cultural phenomenon investigated in both its rural and urban contexts. Thus, making the case study approach which demands indepth study to clearly understand the situation on the ground preferable. Both descriptive and explanatory analytical techniques were used to convey the findings. Embedded case study methodology was used since there is more than one sub-unit of analysis - subsistence settlers and indigenous farmers. Each category was engaged in the in-depth inquiry and findings integrated into a single research and conclusions drawn based on comparisons. This study also used a multiple case study strategy in order to present the distinct influences of rurality and urbanity on tenure arrangements and the nature of food security situation of households at the two different levels. That is, the dynamics of people-land-institution relationship in urban and rural contexts.

The choice of the distinctive (rural and urban) study communities is primarily because of the prevalence of the phenomenon of subsistence farming on customary lands and the variations in seeming differing dimensions. These need to be examined and compared for informed conclusions. First, northern Ghana and the Upper West region have not been the focus of many studies in Ghana even though the country cannot completely develop without them. The phenomenon is widespread in the region and yet not known by many people and researchers outside it. So, the choice of this region opens it up for further discussions and consideration by other researchers and policy makers as well as development partners. In the peri urban area of the Wa Municipality, the influence of urbanisation and rising population contained in literature are influencing changes in customary tenure and service arrangements. However, when it comes to the predominantly rural Fielmua in the Sissala West and Piina in the Lambusie districts, changes in customary tenure and service arrangements are not necessarily attributable to urbanisation or rising population. It made this choice thought-provoking especially that Fielmua experiences (land tenure related) isolated open confrontations between settler farmers and landowners while Piina remains relatively peaceful. This research draws on the circumstances in each of these areas and the measures being put in place to come up with lasting solution strategies in both rural and urban areas as far as customary tenure security is concerned.

Two communities in each of the three districts (making six) have been selected for this research. The study population is mainly subsistence and smallholder farmers. They mostly have farmlands of less than or equal to two hectares i.e. five acres (Samberg, Gerber, Ramankutty, Herrero, \& West, 2016). Respondents were organised into separate focus groups of elderly males and elderly females, youth/middle-aged women and youth/middle-aged men, then female disabled and male disabled in each of the three study communities, and separately for indigenes and settlers. This means that for each study community, six focus groups were interviewed making them 36 focus groups in all. Land owners, chiefs and leaders of settlers were interviewed as key informants. That is, three key informant interviews for each community in 
three districts thus, nine key informant interviews in all. Case study methodology also allows for a variety of methods to be used for data collection in line with the nature of research questions (Meyer 2001; Zainal, 2007). With the qualitative nature of this research, the depth of the interviews is emphasised much more than the number of respondents involved. Hence the combination of key informant interviews, focus group discussions and observations. The methods of data collection, presentation and analysis have been expatiated below.

Key informant interviews (KII) were conducted for chiefs who double as tendamba and, tendamba as well as family heads of settler and indigene groups to elicit the needed information about the genesis of settler farming in the community. The KII also solicited information about customary tenure and service arrangements instituted especially for settlers and other categories of land users. That is, whether the arrangements are still being observed and if not why. And what the challenges are in terms of tenure security and the possible influence on food security.

Focus group discussions (FGDs) with men, women, disabled and the youth and middle-aged enabled them to provide information more freely on their peculiar land tenure and food security challenges. The youth and middle-aged group then brainstormed together with their elders and reached a consensus at various points during joint FGDs regarding how they propose to resolve each of the challenges identified.

Earth observation satellite data facilitated comparison of images of different years and periods that provided some changes for analysis. The spatial data was collected by extracting specific satellite images at different time intervals from 1983 before the area was elevated into a regional status. Visual interpretation of these images 'superimposed' on one another provided useful insights into the phenomenon of loss of farmlands in the urban setting as compared to the rural trend. It also showed which group's parcels are expanding or shrinking and what other factors were responsible for the increasing tenure insecurity in both contexts.

Personal observation of the physical estimates of farm sizes and inequalities for settlers and indigenes and the various categories of people. This served a triangulation purpose confirming the information gathered using other methods. Moods and gestures displayed and observed during the interview process were pointers for further probing of issues.

Through these methods - key informant interviews and focus group discussions for instance, interviewees responded to questions on types of customary land tenure and service arrangements and perceptions on land rights and land tenure security. The techniques of analysis include descriptive statistics used to describe the basic features of the data in the study. Content and comparative analyses were done in order to disclose the real-life socio-cultural, political and economic situations of the phenomenon as experienced by the people and their most preferred mechanisms of solving the challenges they have identified. 


\subsection{Outline of Research}

The thesis is presented in seven chapters:

Chapter one is the introduction. Sub-objective 1 was split into two and therefore, chapter two is based on one which, an article has been published in Land Use Policy. Chapter three captures the other part of sub-objective 1 and based on an article published in MDPI Land journal. Chapter four is based on Sub-objective two, published as a book chapter by Taylor and Francis Group Responsible and Smart Land Management. Chapter five is based on Subobjective three, a paper based on it has been re-submitted to MDPI Land journal. Chapter six is based on Sub-objective four and based on a paper submitted to the Land Use Policy journal. Chapter seven is the synthesis of this entire research. 


\section{Chapter 2 Assessing customary land rights and tenure security variations of smallholder farmers in northwest Ghana}




\subsection{Introduction: indications of land rights variations}

Variations or inequalities in land rights refer to differences in entitlements to land, which largely reflect the social structure of communities. Social structure is the distinctive, stable arrangement of institutions within a community and/or society whereby the human beings living in it interact and live together while belonging to certain commonly established hierarchical categorisations. The social structure theory for Tirole, therefore refers to community's framework of sharing and interactions among its principal groups and institutions as well as the diverse attitudes and interests. This can however lead to some inequalities in opportunities like resource distribution between the groups in terms of land, its rights and tenure (Tirole, 1989). The variations may range from weak (i.e. incomplete and few) to strong (i.e. full compliments) in the multiple layers of land rights. That is, the bundle of rights based on the customary tenure and service arrangements in place (Chiaravalloti, Homewood, \& Erikson, 2017).

Customary service arrangements are non-monetary 'homages' like gifts or labour, which non-member landholders like male settlers are required to seasonally render to male landowners to acknowledge the landowners' ownership rights and renew such landholders' rights on the land. It implies that inappropriately rendering such services can weaken one's land rights. Meanwhile, weak land rights may deteriorate livelihoods especially regarding farming and food security (Anaafo, 2015). Specifically, land rights include the right to access, hold, use, control or transfer land that reflect specific sociocultural and geographic contexts within a land tenure system and may be based on the community's social structure (Alston \& Mueller, 2015). The recognition of these land rights with certainty, according to FAO (2002), also enhances land tenure security. The land rights variations are further evident in uncertainties about use options, restrictions to less fertile and/or least preferred lands by privileged groups, rate at which rights may be changing, kinds of services to render, duration of rights and type of rights to hold. These rights also vary depending on people's status or type of group according to Johnson (2007) as well as their security within a land tenure system as observed by Uwayezu \& de Vries, (2018). These rights must be robust to protect the rights of the landholders (Sietchiping, Aubrey, Bazoglu, Augustinus \& Mboup; 2012).

Some scholars indicate that weaker land rights holders are mostly women who suffer certain implications such as food insecurity and therefore need protection through regulation (Duncan \& Brants, 2004; Nara, Lengoiboni, \& Zevenbergen, 2020; Sietchiping et al., 2012; United States Agency for International Development (USAID), 2016; Uwayezu \& de Vries, 2018). The United Nations (UN) recognise that these land rights variations exist and thus seek to promote equitable access to land, its rights and tenure security. This is contained in the UN's Sustainable Development Goals (SDGs) 1.4 which may influence food security captured in SDG 2.3. Payne and Durand-Lasserve 
(2012) indicate that all attempts to compute the number of people globally, who suffer from insecure and restricted land rights have achieved limited success. Further, according to Asiama, Bennett, \& Zevenbergen (2017); Lengoiboni, Richter, \& Zevenbergen (2019), there is a dearth of land information in customary areas of vulnerable groups who possess unequal and often insecure secondary land rights making them depend on others for land. According to Abubakari, Richter, \& Zevenbergen, (2018) "there is neglect of registration of customary land rights in sub-Saharan Africa" which can make rights weak and less secure. Other examples of weak land rights holders are smallholder herders and migrants who farm for the upkeep of the household and may sell some of their farm produce to purchase what they lack (Cotula, Toulmin, \& Hesse, 2004; Gollin, 2014; Toulmin, 2008). For all these groups, their weakening land rights in society are determined by factors (both human and natural) that they have little or no control over. Meanwhile Kamwi et al., (2018) posit that land use and land cover changes (LULCC) continuously occur with the passage of time that can affect land availability, rights and tenure.

Therefore, understanding the spatio-temporal LULCC patterns can be fundamental for achieving sustainable land management and tenure security for equitable land rights (Kamwi et al., 2018). The spatio-temporal changes observed over the period between 1983 and 2019 which show expanding built areas may invariably imply reduction of farmland or otherwise. This understanding of LULCC patterns can inform the nature and direction of public policy in terms of town planning, land distribution and consequent land rights and land tenure issues in a more equitable manner. Kamwi et al., (2018) found that spatio-temporal LULCC patterns are indeed useful in equitable land management in Zambezi region, Namibia.

Land rights equity and tenure security can also be impacted by socio-cultural factors like status, disability, age, gender, ethnicity and class within a land tenure system (Boudreaux \& Sacks, 2009; Myers, 2013; Payne, Durandlasserve, 2012; Toulmin, 2008; Zevenbergen, 2002b). Therefore, there is the need to assess the nature of land rights variations in the region in order to help provide the type of action needed to address any negative consequences.

The results of this assessment are discussed in the framework of the social structure theory by Nadel (1957) as given by Tirole (1989). The social structure theory has been used to discuss several subjects including crime by Brown \& Justice (2011) in economics; by Economo, Hong, \& Page (2016) and team formation (Farasat \& Nikolaev, 2016). So far, few scholars have discussed the social structure theory on general land issues in the areas of large-scale farming by Goldschmidt (1978) urban land use by Form (1954) and on land tenure security by $\mathrm{Ma}$ (2013) but none specifically touches on land rights variations. This research discusses the social status of smallholder farmers within the hierarchy of the social structure, based on which communities allocate land rights. This may contribute to building the applicability of the social structure theory beyond the spheres mentioned earlier. The empirical data of this research will be juxtaposed with literature based on which an informed opinion will be given and provide any new knowledge emanating from it to add to the existing literature. 
The key questions being explored in this research are:

i) What is the variation or inequality in the bundle of land rights between landowners and settlers in the study area? 2) What is the nature of gender land rights variation within the social structure in the region? 3) How does customary land rights variation/inequality affect various categories of people in rural and urban areas of the study area?

This paper is organised into various sections where section 1 discusses the indications, variations as well as the nature, causes and related controversies of customary land rights and tenure security. Section 2 is on methods and section 3 presents results while section 4 contains discussion. The final section 5 , is conclusion and recommendations.

\subsection{Nature, causes and arguments of land rights variations}

The nature and degree of land rights variation reflects in the bundle of land rights referred to earlier, which could be completely or partially restricted with fewer and weaker choices (Brasselle et al., 2002). Generally, there is unequal distribution of customary land rights in Africa based on the social structure such that one can have de facto possession but no de jure rights and vice versa. This makes the groups holding weaker land rights lose out (Cotula, Toulmin, Hesse, \& et al., 2004; Toulmin, 2008). Meanwhile, equitable land rights give some "assurance effect" for landholders to invest more thereby enhancing production and wellbeing (van Asperen \& Zevenbergen, 2007; Brasselle et al., 2002; Simbizi, Zevenbergen, \& Bennett, 2015; Corsi, Marchisio, \& Orsi, 2017; Gollin, 2014; Nguyen, 2014; Ruerd, 2011; Van Gelder \& Luciano, 2015; Zevenbergen, 2002b, 2002a; Zevenbergen, De Vries, \& Bennett, 2015).

Land rights variations, reflecting the bundle of rights held relate to the type, duration, use and even the size of land that one has which may also influence its tenure security (Alston \& Mueller, 2015; Chiaravalloti et al., 2017; Payne, Durand-lasserve, 2012). On the security or otherwise of customary tenure, one group questions customary land rights security because of various negating reasons including lack of formal documentation (Barry \& Danso, 2014; Chauveau, Cissé, Colin, Cotula, Delville, Neves, Quan, 2007; Cotula \& Neves, 2007; Djokoto and Kyeretwie, 2010; Naab, Dinye, \& Kasanga, 2013). A second group insists that customary land rights are secure based on the landholder's perception (Akrofi \& Whittal, 2011; Bugri, 2008; Kidido, Bugri, \& Kasanga, 2017; Obeng-Odoom, 2012). This debate (reflecting various land rights contained in land tenure), demonstrates that while land rights under customary tenure seem secure they can be unpredictably variable for others if not addressed holistically (Toulmin, 2008). Governments no doubt, have a legitimate role in regulating variable and unequal land rights to minimise the effects on people (Barry \& Danso, 2014a; Toulmin, 2008). This paper therefore seeks to assess the nature of land rights variations within the social structure 
affecting subsistence farmers in the region. It is expected to help provide the type of action needed for effective solution. This can facilitate the productive use of the land including farming towards food availability and food security for the vulnerable and often marginalised farmers.

\subsection{Customary land tenure system and evolution of land rights in Ghana}

Customary land rights variation (and indeed land rights inequality from any locality) is detrimental to vulnerable groups in sub-Saharan Africa. These land rights inequalities have consequences on livelihoods, food security and wellbeing of people in many countries (Antwi-Agyei, Dougill, \& Stringer, 2015; Cotula \& Mathieu, 2008). Most governments in Africa therefore, introduced some land reforms through formalisation, regularisation, legalisation and registration of land rights in the past to halt the related consequences (Bassett, 2007; Chimhowu \& Woodhouse, 2006). These past efforts by governments were supported by development partners which partially yielded minimal outcomes except Namibian Flexible (customary) land tenure system \& Rwandan land reforms (Lawry et al., 2014; Maxwell \& Wiebe, 1999). Rwanda is so far said to be the only sub-Saharan African country to develop a unique land consolidation approach aligned with local customary conditions, and implement it nationwide (Asiama, Bennett, \& Zevenbergen, 2017). Again according to Asiama, Bennett, \& Zevenbergen (2017), Rwanda's example is a locally developed land consolidation programme in a sub-Saharan African country according to its local conditions. Formalisation of land rights in subSaharan Africa generally failed because it is too simplistic and too expensive for the poor in its rural and peri urban areas (Akrofi \& Whittal, 2011; Choplin \& Dessie, 2017; German Federal Ministry of Food and Agriculture (BMLE), 2015; Sanga, 2009; Zevenbergen, Augustinus, Antonio, \& Bennett, 2013). According to Cotula, Toulmin, \& Hesse, (2004); Platteau, (1996), land rights have evolved from communality towards rising individualization which eventually caused landholders to press for creation of duly formalised private property rights. Boudreaux \& Sacks, (2009) and others opine that this will compel the state to respond to such demand by streamlining tenure towards increased rights equity for all categories of landholders. Thus, the transformation of customary land rights in Ghana and the study area contains inevitable land rights variations where changes and differences naturally exist along the structure of society and in line with customary practice. These changes of customary land rights and tenure system have been part of local ways of allocating and using land since time immemorial (Pottier, 2005). The customary process had maintained legitimate land rights contrary to current happenings especially in sub-Saharan Africa where there are increasing claims and counter-claims due to widening variations (Bassett, 2007; Pottier, 2005). This poses threats to the poor, vulnerable and marginalised groups making weak land rights holders increasingly feeling insecure (Antwi-Agyei et al., 2015; Bassett, 2007). 


\subsection{Settlement antecedents in Upper west region}

Everyone may be a migrant/settler in one way or the other since history teaches that all groups of people may have moved at one point in time from one place to another until their current location. Where the migrating group arrived and dwelled for a longtime without encountering any other group making claims of ownership/territorial control over that land, then the migrating group automatically became original occupiers and landowners (Bentsi \& Ankoma, 2018) in da Rocha and Lodoh, (1999) and in Ollennu (1962). However, when the migrants met people already occupying and/or claiming territorial control over particular jurisdictions, the migrants: 1 ) fought to overpower and take control over the place, 2) were assimilated into the earlier occupants' group and the two dwelled together or 3) settled as newcomers i.e. settlers. Generally, a definite number of years of dwelling in a place may automatically absorb the migrants as part of the group they met. However, in other cultures like Ghana, the status of "settler" is permanent. This is irrespective of how long a new-comer group may have lived in the new location. Once they met others already occupying and/or exercising control over those areas and such original occupants are not prepared to assimilate the new-comers, the new-comers remain settlers forever.

Thus, in Ghana and the upper west region, once a "new-comer" or settler group met people already dwelling in a place, the "new-comer's" status as a settler remains in perpetuity. This settler group is referred to as mobile farmers or labour migrants by Lentz (2001). In other words, once there is already a legitimate group of landowners on the land now being occupied by the settlers and this is accepted by both new-comers (i.e. settlers) and first-comers (landowners), that settler-landowner status will remain always. Because of this, those moving (i.e. the new-comers or settlers) can hardly assert themselves as first-comers (original landowners) but they have to become clients under the first-comers (landowners). The landowners thus, have more abundant land and stronger (almost absolute) land rights than settlers who usually hold secondary land rights transferred to them by the landowners (Biitir \& Nara, 2016; Lentz, 2001). There are instances where in the distant past the settlers looked for landowners and entered into various land tenure arrangements with them (Djokoto and Kyeretwie, 2010). Landowners in the past would allocate vast unoccupied areas to settlers and as the years passed, the settlers populated and transformed those places to typically settleroccupied areas. This is the scenario in some communities in the study area where settlers dominate in numbers.

\subsection{Social structure theory}

The term social structure refers to the system of socio-economic stratification, which emphasises sub-cultural values of class, social institutions or other arrangements of relations between large social groups in human organisations. Social structure theory therefore explains the community's framework of sharing and interactions among its principal groups and institutions as well as the diverse attitudes and interests, which can lead to some variations between the groups (Tirole, 1989). The social differentiations can reflect status, ethnicity, gender, age etc. These differentiations tend to make one group 
advantaged in terms of resource allocation against another (Economo et al., 2016).

In the analysis of social structure, Tirole's (1989) theory indicates that the role of diverse attitudes and interests of social beings as groups is revealed. The social structure theory also explains that the social relationships reflect the distribution of power between and among groups. The resource distribution between the groups is institutionally structured, defined and regulated and thus influence land rights allocations too. Tirole's theory further indicates that the relations explicitly exclude inter-personal ones but places premium on interactions across groups. Tirole (1989) then concludes on social structure as the features contributing to the make-up of societies. Clarifying that social structure is concerned with the principal forms of social organization, i.e. types of groups, associations and institutions. This theory supposes that the distribution of resources including land is along the existing organisation of society where some privileged categories of people receive more while the underprivileged receive less. The theory concedes that the dynamism of society notwithstanding, it cannot dissolve these variations of rights since they partly define every human community. The results from this research work reflect the distribution of land rights and tenure security based on these social dynamics contained in the theory across groups in the communities. The results were therefore analysed using the social structure theory, which also portrays differing social groups in terms of power and resource allocation including land. Analysing land rights of smallholder farmers in seemingly homogeneous communities using the social structure theory contributes to existing knowledge about community inequalities and their land rights allocations. The relevance of using this approach in this research is a call to avoid the temptation to over-generalize the use of the social structure theory to analyse all social phenomena. As this research has revealed, some deficiencies may exist in particular social structures contrary to the general understanding of applicability.

\subsection{Methodology}

This is an exploratory research because it was conducted on 'a not clearly studied problem', to unveil previously hidden facets of reality (Reiter, 2017). The purpose is to assess variations of land rights among different categories of people. It further aims to ascertain how this may affect them in terms of strengthening their land rights and securing their land tenure as well, and then suggest ways to minimise these variations. Focus group discussions (FGDs), key informant interviews and interviews with key persons in key institutions were conducted in addition to the manual visual interpretation of satellite images for triangulation purposes.

\subsubsection{Study location}

The map in Figure 3, gives the location of the three study districts in the regional context and the region in the national context. The characteristics of the specific communities studied are contained in Table 1 . Small-scale subsistence agriculture and labour migration are dominant here in the study area as well as inter- and intra-regional agricultural migration for subsistence 
farming purposes (Lentz, 2001). There are varied categories of land rights that prevail in the study area.

The types of land rights, interests or titles in the study area are mentioned briefly below. 1) allodial title: the highest interest in land, communally owned, 2) customary freehold interest: family land use rights held perpetually as members of the allodial title, 3) Common law freehold right: acquired through express grant from the allodial owner or customary freeholder, either by sale or gift or other arrangements usually held in perpetuity and 4) 'Leasehold' rights. The land rights of smallholder farmers are derived from one or the other of these higher interests depending on the parties and circumstances involved in the study communities.

There are six study communities as shown in Table 1 , located within the map in Figure 3. They cover a total land area of $3,641.74 \mathrm{~km}^{2}$. These were purposively selected because of the prevalence of smallholder settler farmers in these communities. A settler (see explanation in appendix 1 ) is a person who (in relative terms) comes into a community (where others: first-comers, already dwell) to live permanently and farm on land he/she does not own but holds secondary land rights to it. S/he mostly acquires the land through the customary system (farming arrangement) where the land is given free of charge for subsistence farming purposes. Thereafter, a token gift is customarily supposed to be given annually to the actual landowner (see explanation in appendix 1) after every harvest. Some of the communities (e.g. Fielmua, Piina number (2) and Kunfabiala) are entirely inhabited by settlers but the rest have both landowners and settlers living together. Another reason for the choice of these communities is the uniqueness of their land tenure system prevailing largely in the two upper regions (upper west and upper east) of northern Ghana. Here, families or clans hold the land as compared to many parts of Ghana where chiefs hold the land in trust for the landowning group. The areas visited included Sing and Kunfabiala communities in the Wa Municipality, approximately $234.74 \mathrm{~km}^{2}$, and the most urbanised place in the study area. Located over $200 \mathrm{~km}$ further north, the other two rural places are Piina number (1) and Piina number (2) communities in Lambusie-Karni (1,356.6 km²) and, Fielmua and Nimoro communities in the Sissala West $\left(2,050.4 \mathrm{~km}^{2}\right)$. The rural districts border each other with travel distance of over $40 \mathrm{~km}$ from one end of one district to the other. The choice of rural and urban areas was to determine the extent to which their urbanity or rurality influences land rights variations and tenure (in)security of landholders.

\subsubsection{Fieldwork}

The fieldwork was conducted in Upper West Region of Ghana during a seven months period from cropping to harvesting i.e. from June-December, 2018. The period was useful as it facilitated periodic and multiple visits to communities for assessment of how different land rights affected processes and activities of farming throughout the cropping season. There were three landowner and three settler communities selected in all. Settlers in Ghana, are new-comers permanently resident in their current habitation while landowners are the indigenes and first to occupy land in the study area. Details of the numbers of focus group participants are shown in Tables $2 \& 3$. 
Table 2 Landowner FGD participation - Sing, Nimoro \& Piina no. 1

\begin{tabular}{|l|l|l|l|l|l|}
\hline Landowner & $\begin{array}{l}\text { Male } \\
\text { focus } \\
\text { groups }\end{array}$ & $\begin{array}{l}\text { Number of } \\
\text { male } \\
\text { participants }\end{array}$ & $\begin{array}{l}\text { Female } \\
\text { focus } \\
\text { groups }\end{array}$ & $\begin{array}{l}\text { Number of } \\
\text { female } \\
\text { participants }\end{array}$ & $\begin{array}{l}\text { Total } \\
\text { number of } \\
\text { Participants }\end{array}$ \\
\hline Elders & 3 & 31 & 3 & 34 & 65 \\
\hline Disabled & 3 & 29 & 3 & 26 & 65 \\
\hline $\begin{array}{l}\text { Young } \\
\text { adults and } \\
\text { middle- } \\
\text { aged }\end{array}$ & 3 & 36 & 3 & 35 & 71 \\
\hline Total & 9 & $\mathbf{9 6}$ & 9 & $\mathbf{9 4}$ & $\mathbf{2 0 1}$ \\
\hline
\end{tabular}

Source: author's construct, fieldwork, (2019).

\subsubsection{Interview respondents and FGD participants}

The respondents are landowners and settlers (thus male and female), categorised into elders, disabled and young adults and middle-aged (in Tables 2 \& 3). This categorisation was aimed at determining whether land rights inequalities exist across these groups. Elders in Ghana according to the 2010 Population and Housing Census report in Republic of Ghana (2012) are people aged 60 years or over, while young adults and middle-aged are between 18 and 59 years. It turned out during the data collection that land rights and tenure did not influence these sub-groups (i.e. whether elder, aged, disabled, able-bodied or young adult and middle-aged). Rather, the main groups of landowners, settlers, males or females influenced people's land rights and tenure. Therefore, the results have been presented to reflect these findings from the fieldwork.

In each community, one head of landowners was interviewed as a key informant. The landowner is known locally as tendana among Waala ethnic group in Sing community, tengansob among Dagara ethnic group in Piina number (2) and Fielmua communities and tortina among Sissala ethnic group in Nimoro and Piina number (1) communities. Similarly, the heads of three settler communities were also interviewed as key informants. Also, two interviews of key persons in key institutions were conducted: 1) one in the only state land agency in the region - Lands Commission (LC) and 2) one out of the three government assisted local land management bodies in the region: Wa Central Customary Land Secretariat (WCCLS). The number of participants in each FGD averaged 10. This corresponds with the recommendation of Hancock, Ockleford, \& Windridge, (2009) and Kothari, Kumar \& Uusitalo, (2014) that the number of people in a focus group should be between eight and 12. A total number of thirty-six FGDs were conducted (and moderated by the researcher himself) in the three districts. In each district, three landowner and three settlers focus groups were interviewed with varying number of participants as shown in Tables $2 \& 3$. There were 18 settler FGDs with 201 participants and 18 landowner FGDs with 197 participants, giving a total of 398 participants during the fieldwork. 
Table 3 Settler FGD participation - Kunfabiala, Fielmua \& Piina no. 2

\begin{tabular}{|l|l|l|l|l|l|}
\hline Settler & $\begin{array}{l}\text { Male } \\
\text { focus } \\
\text { groups }\end{array}$ & $\begin{array}{l}\text { Number of } \\
\text { male } \\
\text { participants }\end{array}$ & $\begin{array}{l}\text { Female } \\
\text { focus } \\
\text { groups }\end{array}$ & $\begin{array}{l}\text { Number of } \\
\text { female } \\
\text { participants }\end{array}$ & $\begin{array}{l}\text { Total } \\
\text { number of } \\
\text { Participants }\end{array}$ \\
\hline Elders & 3 & 34 & 3 & 35 & 69 \\
\hline Disabled & 3 & 27 & 3 & 29 & 56 \\
\hline $\begin{array}{l}\text { Young } \\
\text { adults } \\
\text { and } \\
\text { middle- } \\
\text { aged }\end{array}$ & 3 & 36 & 3 & 36 & 72 \\
\hline Total & 9 & $\mathbf{9 7}$ & 9 & & \\
\hline
\end{tabular}

Source: author's construct, fieldwork, (2019).

The focus group discussions responded to questions on types of land rights, variations in terms of status, gender and location. Other questions hinged on changes in farm sizes and construction of buildings (with the help of the satellite images provided during discussions) and their effects on farming and food availability and security. Key informants provided information on the nature of inequalities in customary land rights and the temporal changes of groups' land rights and building developments that occurred since any major policy initiative in the area from 1983. They also provided information on norms and practices governing land rights variations and how people conform to them.

\subsubsection{Spatial data and other data}

Time series satellite images were extracted from Google Earth Pro, similar to the approach used by Arko-Adjei, Jong, Zevenbergen, \& Tuladhar, (2009). Then, manual visual inspection, interpretation and narration was explored. Thereafter, trends of changes in spatial structure, land tenure changes and land use patterns were described in relation to land rights variations. The FGDs identified the location of farmlands, houses as well as other past and current structures constructed including what has been replaced and how that impacted on land availability and rights variations. Settler key informants narrated how they lost farmlands and what tenure changes preceded or proceeded the developments.

Other data gathered included audio and video recordings of FGDs that were later transcribed as well as field notes, handwritten texts of interviews and observations. Yet others are photographs of farms, sites and participants and of visual inspection and manual interpretation sessions of satellite images.

\subsubsection{Data analyses}

Audio recordings were transcribed and the process of content analysis carried out (see box 1) to identify and match emerging patterns, trends and themes of different categories of people. 


\section{Box 1}

The process of carrying out the content analysis in this research

1) The first step was, to thoroughly read and re-read through data to be more familiar with it.

2) In step two - there was identification from the written and transcribed data, key themes about (in)secure tenure, weak or strong land rights, food (in)security, reducing or increasing farm sizes, most affected people mentioned and vulnerable or marginalised groups identified during the FGDs.

3) In step three - colouring and underlining similar responses from the FGDs.

4) In step four - assigning colour codes to specific similar data in order to describe the content. For instance, green colour for desirably strong rights, secure tenure and food security; red colour for undesirably weak land rights, insecure tenure and food insecurity and then yellow colour for vulnerable and marginalised groups.

5) In step five - searching for and matching similar patterns or themes in the colour codes across the different FGDs.

6) In step six - the researcher reviewed the themes to ensure that those in the same category convey the same ideas or information.

7) In step seven - the researcher described and reported the messages/information emanating from the analysis of the FGDs.

Interpretation was done to identify and understand groups' aspirations and fears regarding land rights and tenure security possibly influencing their livelihoods as well as food security concerns. Results are discussed within the framework of society made up of different groups with unequal powers and rights based on the social structure theory as introduced in 1.3.

\subsection{Results}

This section presents results on nature of variations in customary land tenure and rights in northwest Ghana. It analyses landowners' and settlers' rights, and absence or presence of age and disability land rights. Also, it presents land rights variations or/and trends between males and females and, rural and urban areas based on status, gender and location. The results also draw links between land rights variations, farm size changes, trends in infrastructure development and farming activities for food production and food security.

\subsubsection{General nature of customary land rights in the study area}

Generally implicit in land access and holding in the study area are that, land rights are derived from the land tenure system and service arrangements. As contained in Table 4 adapted from Payne, land rights vary among and between groups. Since Table 4 is adapted from Payne, the pre-determined themes in column 2 i.e. ownership, occupy, inherit etc. are from Payne. The corresponding information is data (containing the bundle of land rights) from my fieldwork indicating who holds what and how many rights. Those holding sizeable lands have more rights and are relatively highly tenure secure than those holding less lands. The data revealed that families and clans operate the land tenure system in northwest Ghana where their head (tendana, tengansob or tortina) is the custodian of land (rights) on behalf of the landowning group. 
The respondents said there is 'no land sale' especially for subsistence farming purposes. But that the land is given out 'free' to these farmers. In this case, they said that non-member landholders (particularly male settler farmers) are customarily expected to render customary tenure services but not cash payments in return. That is, either a token gift (in Figure 4) or labour to landowners annually to renew their land rights. They added that this "service" is also to acknowledge the authority of the landowner over the non-member landholder (e.g. settler).

Typically, the respondents acknowledged that the customary land tenure arrangements in this area on farming rights are "cropping but not sharecropping arrangements." The cropping land right is granted to persons to build, occupy and farm on the land. By this arrangement and irrespective of land size, such persons - usually settlers, are required by custom to perform a homage (no cash involved) by providing (kagyin or kaju) in Figure 4, as a 'token gift' to landowners after every harvest. According to male landowners FGDs, the male settlers are not expected to share harvests 'profitably' with male landowners. This is unlike (abunu i.e. 1:1 or abusa i.e. 2:1 ratio) sharing/service arrangements pertaining in southern Ghana. Additionally, the FGDs indicated that settlers in northwest Ghana may provide labour services if landlords demand it or at settlers' will. But they said women typically do not perform such tenure services except to maintain good relations with males primarily as wives, daughters etc. Moreover, both settlers and landowners in all the study communities said they cannot recall the last time these tenure services were observed. Adding that such tenure practices are difficult to legally enforce currently, thereby causing non-adherence and consequently widening land rights variations and tenure insecurity. 


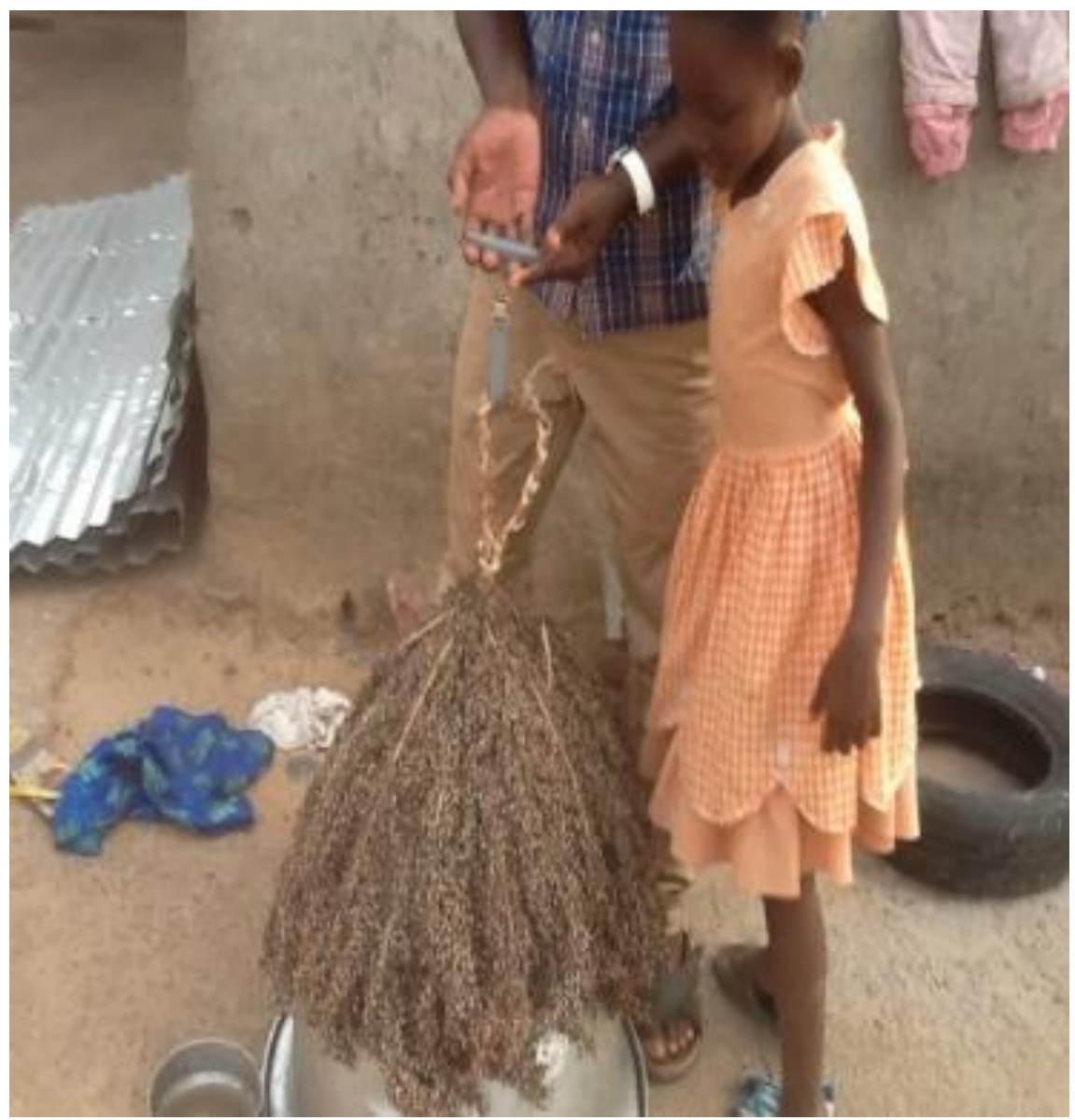

Figure 4 Sample of annual 'token gift'. Source: fieldwork, (2019).

Land rights in the study area were said to differ based on one's status and sex as shown in Table 4 and nothing else. Age and disability were found not to influence land rights and land tenure in the area. This explains the seeming difference between the groups used in the FGDs and the groups shown in the tables containing results. In other words, all age and disability groups enjoy similar land rights as males or females and as landowners or settlers as contained in Table 4 and the rest of the results and discussions. The respondents indicated that these bases of land rights inequalities have implications for their investment intentions, land-based production and meeting their livelihood needs. 
Table 4 Community land rights \& tenure arrangements

\begin{tabular}{|l|l|l|l|l|l|}
\hline $\mathbf{S / n}$ & $\begin{array}{l}\text { Land } \\
\text { right/tenure } \\
\text { arrangement }\end{array}$ & $\begin{array}{l}\text { Settler } \\
\text { females }\end{array}$ & $\begin{array}{l}\text { Landowner } \\
\text { females }\end{array}$ & $\begin{array}{l}\text { Settler } \\
\text { males }\end{array}$ & $\begin{array}{l}\text { Landowner } \\
\text { males }\end{array}$ \\
\hline 1 & Ownership & - & - & - & $*$ \\
\hline 2 & Occupy/use/enjoy & $*$ & $*$ & $*$ & $*$ \\
\hline 3 & Inherit by heirs & - & - & $*$ & $*$ \\
\hline 4 & Transfer to others & - & - & $*$ - & $*$ \\
\hline 5 & Sale & - & - & - & $*$ \\
\hline 6 & Develop/improve & - & - & $*$ & $*$ \\
\hline 7 & Cultivate/produce & $*$ & $*$ & $*$ & $*$ \\
\hline 8 & Access credit & - & - & - & $*$ \\
\hline 9 & Enforcement & $*$ - & $*-$ & $*$ & $*$ \\
\hline 10 & Pecuniary & $*$ & $*$ & $*$ & $*$ \\
\hline 11 & Sharecropping & - & - & - & $*$ \\
\hline 12 & Rental & - & - & - & $*$ \\
\hline 13 & Purchase & $*$ - & $*-$ & $*$ & - \\
\hline 14 & Give as gift & - & - & - & $*$ \\
\hline 15 & Common property & $*-$ & $*-$ & $*-$ & $*$ \\
\hline
\end{tabular}

Source: fieldwork, (2019) and adapted from Payne, (2004, 2012).

Star (*) means the land right is available. Star \& dash (*-) means there is limited availability while dash (-) means the land right is not available for the particular group.

\subsubsection{Land rights variations between landowners and settlers}

It can be observed from Table 4 that all male settlers have land transfer rights just like male landowners, but participants of the FGDs indicated that male settlers' transfer rights are limited to heirs and close relatives. Meanwhile, male landowners said they (landowners) generally possess unlimited rights to transfer including sale or gift and exclusive rights to use land as collateral. From Table 4 as presented from FGDs, male landowners possess almost all (i.e.14) customary land rights to own, sell, give as gift, rent and use as collateral which settlers do not have. Consequently, male landowners have more complete bundle of land rights and tenure security than male settlers do. It is in this sense that some male settlers in some communities are asserting landowner status and claiming to possess all 14 customary rights on the lands they hold (though they are currently being contested in court). But male settlers in some of the other study communities possess about seven out of the 15 in the bundle of customary land rights in the tenure arrangements (again see Table 4). Also different from the rest of the study area, land use rights of male settlers in Piina were mentioned not to include tree rights whether to plant or fell, because possessing the right to plant or cut trees defines actual land ownership there. Settlers said they generally do not have actual ownership of farmland except building land (i.e. for durable not 'farm' housing) which they buy at commercial rents sometimes higher than urban rates and then cultivate at the backyard. 
By custom according to the FGDs in all the communities, male landowners have exclusive rights to re-enter lands held by secondary rights holders at any time in consultation with them. However, the male landowners said that these customarily prescribed consultations are unfavourable to them and so they do not fully observe them. Even though land use rights are enjoyed by all categories of landholders, the accompanying tenure services differ depending on status i.e. as settlers or landowners or, as males or females. For instance, male landowners naturally render no services or payments for the lands they own, occupy and use. Customarily, male settlers should not make monetary payments but rather render labour or provide tenure services to their landowners in order to enjoy continuous land (use) rights. However, the FGDs reported widespread instances where some male settlers have in recent times been requested to pay money (and some do). The amounts range between GHS3000 and GHS5000 i.e. 600Euros and about 1000Euros per (100 x 100 feet or 30 square metres) plot for 99 years lease period. Otherwise, they said they risk losing the land and its rights. Both male landowners and male settlers said the growing inequalities in land rights is exacerbated by monetary rewards. For instance, (see Box 2):

\section{Box 2}

The sample 'token gift' in Figure 4 weighs $10.4 \mathrm{~kg}$ even though weight and size were less important in the land tenure arrangement because physical inspection is conducted implicitly. On the average, the $10.4 \mathrm{~kg}$ of grains costs about 40GHS equivalent to 7.2Euros. Meanwhile, accumulated farmland held by a settler is 2 hectares equivalent to about 20 plots if demarcated where 1 plot is $1 / 4$ of an acre. Currently, given that 1 plot is sold at 3000GHS which is 600Euros, then 2 hectares is valued at 60,000GHS or 11, 000Euros for 99 years. It translates to $606 \mathrm{GHS}$ or 111 Euros per year to the landowner if he sells the land as opposed to giving it out to settlers for farming purposes. It is therefore clear from the above analysis why landowners prefer land sale to the 'token gift' from settler farmers which the settlers have been accused to have even stopped. The landowners are gradually taking their lands in possession of settlers by using various but unacceptable customary means, settlers asserted. This explains the growing inequalities among secondary land rights holders (i.e. all women and male settlers) as compared to male landowners in the area.

In the midst of all the above land rights variations being introduced, male settlers said prior information to them is seldom provided on intended changes (monetisation) on their land tenure arrangements (except tenure services). The male settler FGDs said since the rights to trees are exclusively enjoyed by male landowners, adding that this practice increases land rights uncertainty, affects farm fertility and decision making towards food production to promote food supply to the household. Male settlers further said they have to consult their male landowners who often will not give permission on major decisions like tree planting or plantation development in these areas unless male settlers pay commercial rents for the land. As a result, some male landowners (not male settlers) have cashew plantations, larger farmlands and expressed freedom to engage in commercial farming. Male landowners further said they have (unexplored) rights to rent or enter into sharecropping arrangements with 
any other person they want. They said the power to take all land rights and tenure decisions rests with them who own, possess or enjoy some de facto land rights on the lands in their direct possession and all de jure land rights on their lands held by others. During FGDs, all six different groupings were asked to express their level of land rights and implicit tenure security on a line from low to high. This is represented in Figure 5. The trend of responses as presented in Figure 5 shows that male landowners irrespective of age or disability possess more land rights and therefore are more tenure secure than all others do. This finding clearly corresponds with the type and number of land rights held by various groups in Table 4. Similarly, male settlers whether elders, disabled or young adults and middle-aged also indicated the same level of land rights enjoyed though less secure than that of male landowners.

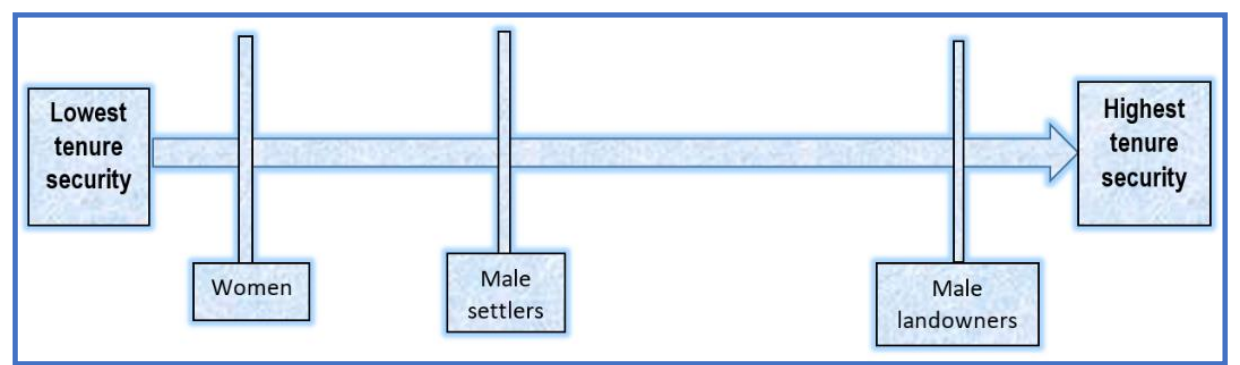

Figure 5 Levels of groups' land rights \& tenure security in study area. Source: author's construct, fieldwork, (2019).

In the words of a male settler farmer from Piina speaking on behalf of the rest:

"Houses were few and we could easily count them. There were vast fallow lands surrounding houses and at the outskirts of the communities too. Land was therefore abundantly available for our use. But now, even though there are few additional buildings as compared to urban areas, landlords have either received or anticipate to receive monetary rewards from developers through land sale. As a result, they do not value the social (moral and humanitarian) considerations of land tenure and service arrangements on land rights between their forbears and our ancestors any longer. As smallholder settlers, we are already so deprived that we cannot regularly afford the landlord's 'token gift' anymore, talk less of financial capacity to compete with developers over land. With threatening tenure insecurity faced with imminent eviction, peaceful coexistence and general development are gradually eluding us. And as settlers with no other alternative for survival or of dwelling, we fear the worst, which is resistance that can degenerate into violence that may worsen the current land tenure and food insecurity. Imagine that we have now been repeatedly prompted to buy land for building at scary rates [i.e. 3000-5000GHS or 526877 Euros] for a plot which is a 1/4 of an acre. This is similar to the urban areas but this used not to be the case however we are stuck and have to raise it or ... [paused un-end and bowed his head as if to hide or prevent tears from running down his cheeks]. In addition, landowners are insinuating that we shall soon pay cash for farmland too [another added]. The seeming unoccupied lands [in Figure 8] have actually been sold out but developers will not even give us permission in the interim to farm on them. We now survive by 
encroaching on people's lands, engaging in non-farm and off-farm activities as well. You see... [he also paused and said hmmm, shaking his head, apparently disturbed by the state of current land rights with little or no hope for a solution as whispered by others around]."

Yet another settler farmer within the same FGD explained that social good and peaceful co-existence have been the basis of customary land relations with settlers in past land rights and tenure arrangements "until recently that trends are changing [referring to monetisation of land] and we have to change alongside". The FGD respondents said tenure services in the form of farm labour during the farming season or the 'token gift' are supposed to be provided by male settler farmers to male landowners after every harvest for land and its rights. But in practice, their land rights currently seem much less than what is customarily prescribed due to the changes being introduced which again a male landowner from Nimoro indicated:

"We are trying to convert [unilaterally though] all customary land rights obtained in the past to leases [connotes registration automatically] so that we can exercise the needed monitoring and control over our lands in the hands of non-indigenes (i.e. settlers). This is one major way to secure our lands for our benefit now and in the future as development and land value appreciations are inevitable. But some settlers are resisting this and insisting that our ancestors gave them absolute ownership rights sometime in the past and that is why we are in court for them to prove it."

It is imperative to note from the interviews that land rights of male landowners may not have changed from a temporal perspective even though farm sizes reduced by about half in nearly four decades. In spite of this, male landowners said they still have lands of up to four hectares as compared to their male settler counterparts who report to hold two hectares on the average. In addition to this, male settler farmlands are witnessing more land reduction than male landowners and at a faster rate (about five times faster) as seen in the graphs in Figures $6 \& 7$. This can similarly be observed in the satellite images in Figures 8 \& 9 with the increasing customary land tenure transformations experienced between 1983 and 2019. The reason from literature is that male settler settlements are located at the entrance to all such communities (rural or urban) and therefore the places where the development of these settlements starts and is vibrant. Male settlers said their male landowners take advantage of this to sell, seize or litigate on these lands thereby preventing them (settlers) and sometimes the landowners themselves from using such lands when the matter goes to court and an injunction is placed on the land. 


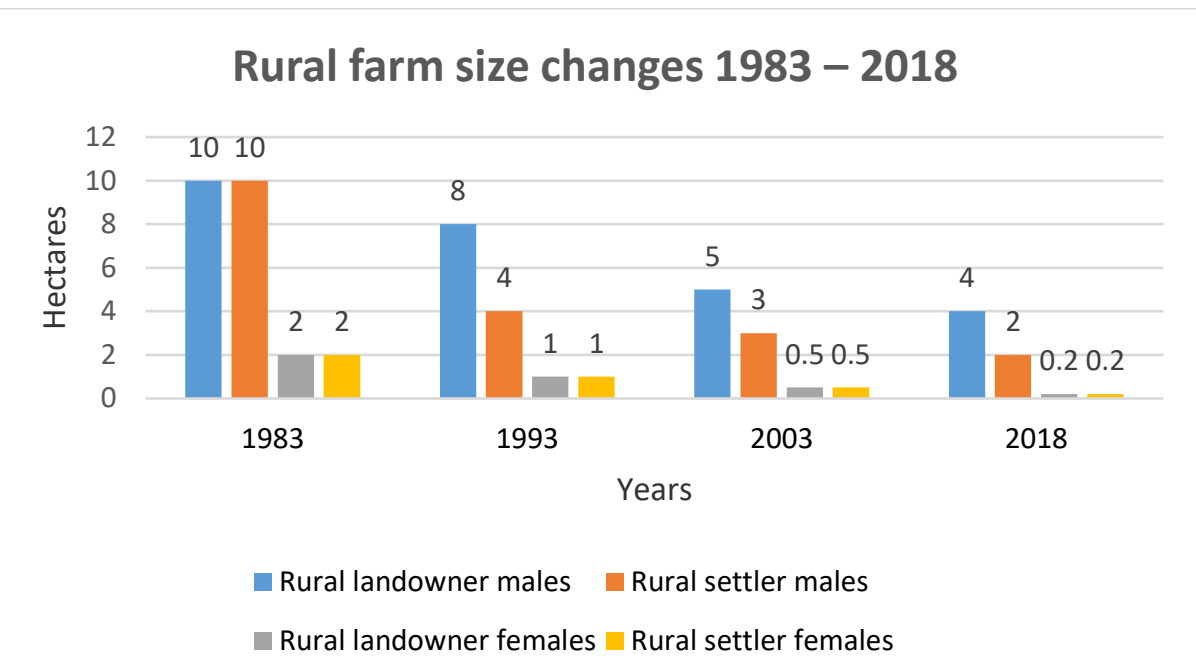

Figure 6 Temporal changes of farm sizes in rural setting. Source: Fieldwork, (2019).

Table 5 Rural farm size changes

\begin{tabular}{|l|l|l|l|l|}
\hline Group/Year & (ha) $\mathbf{1 9 8 3}$ & $\begin{array}{l}\text { (ha) } \\
\mathbf{1 9 9 3}\end{array}$ & (ha) 2003 & $\begin{array}{l}\text { (ha) } \\
\mathbf{2 0 1 8}\end{array}$ \\
\hline Rural landowners & 10 & 8 & 5 & 4 \\
\hline Rural settler males & 10 & 4 & 3 & 2 \\
\hline $\begin{array}{l}\text { Rural landowner } \\
\text { females }\end{array}$ & 2 & 1 & 0.5 & 0.2 \\
\hline Rural settler females & 2 & 1 & 0.5 & 0.2 \\
\hline
\end{tabular}

Both male settlers and male landowners indicated that before the Upper West region was created nearly four decades (36 years) ago in 1983, both groups held over 10 hectares of farmland per household (Figure 6). However, they have lost so much land over the years to the extent that continuous cropping has become the common farming practice. The reasons for the land losses based on tenure changes they said, are influenced in part by general building developments due in part to population growth and urbanisation. The consequent sub-division of farmland among growing family sizes, resulted in reduced farm size per household for all smallholder farmers. But information from the satellite images in Figure 8 do not show much physical development to support the expressed land shortages and land rights variations. When asked to explain this situation, the FGD respondents across all communities indicated that the anticipation of urbanisation or some form of development with its attendant monetisation of land due to land value appreciation is influencing land rights changes and variations. This occurrence is widespread in all the districts and specific towns/settlements visited. They are particularly: Kunfabiala near Wa, Piina in the Lambusie-Karni district and Fielmua in the Sissala west district. There were visibly vigorous ongoing construction/developments in Fielmua and Piina towns. The settler farmers attributed these developments to themselves. The settlers then contrasted 
these supposedly progressive developments against the low level of development in Lambusie town, which is even the district capital. A settler farmer from Piina told landowners during the joint community workshop that the absence of settlers in Lambusie particularly, was the reason for its slow pace of development as compared to the solely settler inhabited Piina number 2 and Fielmua. These developments are what settlers and landowners both agree to be influencing the introduction of "new" customary tenure and service arrangements thereby weakening land rights and creating tenure insecurity. The transformations (e.g. monetised tenure arrangements, re-entry on settler land without prior consultation, reduced settler farmlands, uncertain tenure durations, unilaterally changing customary norms etc.) according to settlers, currently taking place are such that land rights of settlers are often more affected as compared to landowners. Settlers said they (settlers) are rejecting these new changes, which is leading to some land rights and tenure disputes, which they currently witness in their communities.

Groups most affected by land rights variations and customary tenure insecurity therefore, are male settlers on one hand, and both categories of women on the other as stated above. Note that "female landowners" are women who hold land as daughters, sisters, wives or widows coming from the landowning group. Similarly, female settlers are women who hold land as daughters, sisters, wives or widows coming from the settler group. Both categories of women in this (patriarchal) study area do not independently own land but may hold it through their male relatives. Meanwhile as mentioned earlier, settlers generally constitute $80-100 \%$ of all the inhabitants of these two rural districts and about $60-70 \%$ of the population in some of the urban communities visited.

On the ground, some male settlers said they hold less than an acre (i.e. 0.3 of a hectare) of land while still unsure of maintaining it under current changing tenure practices. In the urban area, the situation is about the same for male landowners as those in the rural area but worse for the rest of the groups. For instance, apart from their houses for dwelling, male settlers and women claim to have no farms left and even their building space is under threat of being sold out. The FGDs discussed that the resistance by male settlers of the widening land rights variations with male landowners, breeds some tension, creates suspicion and causes tenure insecurity for both groups.

The application of the satellite images was useful by showing the general temporal land use patterns. This facilitated the assessment of general farming area reduction and possible increase in built-up area to enable analysis of reducing farms versus building infrastructure development.

\subsubsection{Gender variations of customary land rights}

A key finding regarding gender is that male and female land rights were reported to be unequal in all the communities visited as can be observed in Figures 6 \& 7 . 


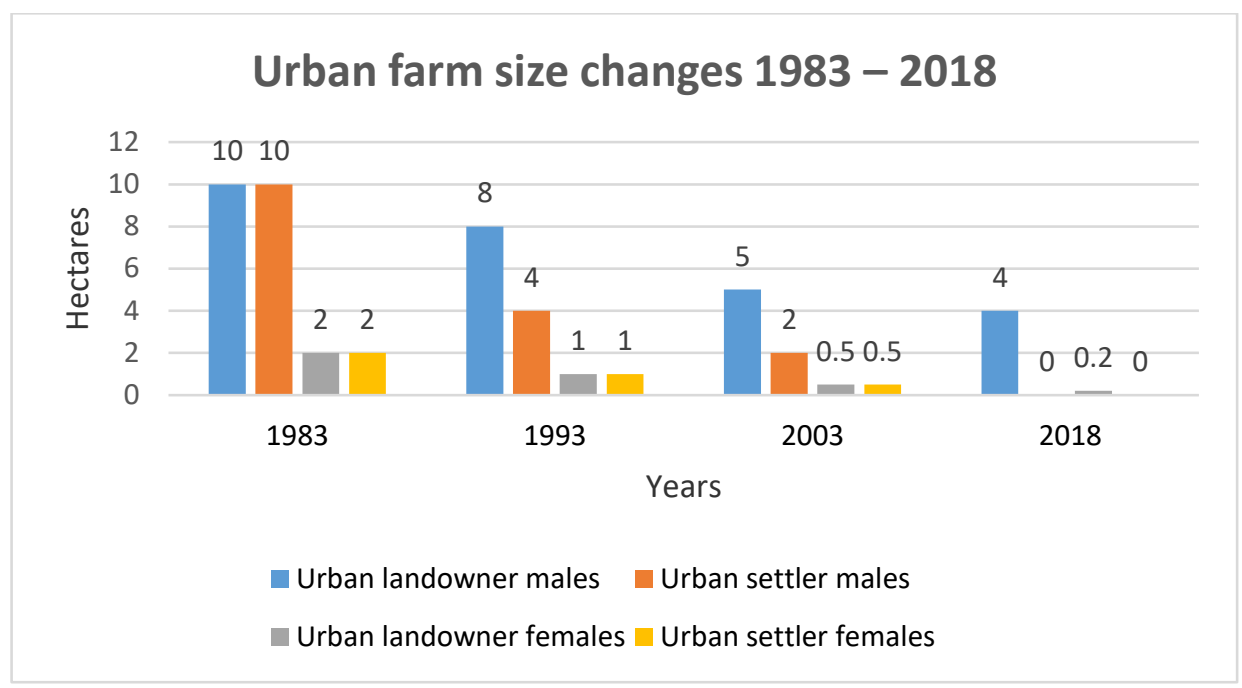

Figure 7 Temporal urban farm size changes. Source: Fieldwork, (2019).

Table 6 Trend of urban farm size changes.

\begin{tabular}{|l|l|l|l|l|}
\hline Group/Year & (ha) $\mathbf{1 9 8 3}$ & $\begin{array}{l}\text { (ha) } \\
\mathbf{1 9 9 3}\end{array}$ & (ha) $\mathbf{2 0 0 3}$ & $\begin{array}{l}\text { (ha) } \\
\mathbf{2 0 1 8}\end{array}$ \\
\hline Urban landowners & 10 & 8 & 5 & 4 \\
\hline Urban settlers & 10 & 4 & 2 & 0 \\
\hline $\begin{array}{l}\text { Urban landowner } \\
\text { females }\end{array}$ & 2 & 1 & 0.5 & 0.2 \\
\hline $\begin{array}{l}\text { Urban settler } \\
\text { females }\end{array}$ & 2 & 1 & 0.5 & 0 \\
\hline
\end{tabular}

Generally, all females from settler and landowner groups were mentioned as having weaker access to customary land and have fewer land rights as shown in Table 4 compared to all male settlers or male landowners. One would expect that females from landowning groups would have stronger land rights than those from non-landowning groups. However, the results show that settler males rather have stronger land rights than "landowner females" (i.e. females from landowning groups) 'in their own homeland.' All the focus groups (including female FGDs) were emphatic that women do not own customary land and have to depend on male relations for land rights and tenure security. This can have consequences as one "female landowner" revealed that:

"Because women have weaker land rights, a simple disagreement between husband and wife is enough for us women to lose our rights on particular lands. Also, the men often take back or change the land in the possession of we women at any time even without any provocation."

The above notwithstanding, widows in the study area where the patrilineal system is practised, were said to have relatively stronger land rights on their late husband's land than 'independent' daughters (who are not married), on their father's lands. Even if a father/husband dies, the widow or adult sons (but not daughters) inherit the land and its rights in line with custom. 


\subsubsection{Variations between rural and urban land rights and tenure issues}

The third category of variations observed in this study is between the same groups in rural and urban settlements. Figures $6 \& 7$ show that the right to recognition, certainty and protection of the same land size held has changed over the years. This is noticeable in the urban communities and against male settlers than male landowners and in the rural communities. In the urban area in Figure 7, there are virtually no recognised farmlands for all the settlers holding 'free' farming (secondary) land rights. This corresponds to the same trend of fewer land rights of male settlers and all women than male landowners in Table 4. Suffice to say that rural land rights and tenure security are also worsening as rent of one plot of land costs on average the same (4000GHS or 700Euros) as in the urban area. Changes in customary tenure and service arrangements of settlers in the urban area seem directly influenced by actual and anticipated expansion of physical urban infrastructure in Figures 8 \& 9. On the contrary, with less LULCC - fewer building development in rural areas in Figures $10 \& 11$, land rights and tenure changes may not be attributed to direct effects of urbanisation or population growth. Consequently, FGD respondents said the anticipation of future land value prospects through information from urban areas in parts of Ghana on land related issues influences current land rights variations and the resulting tenure insecurity. 


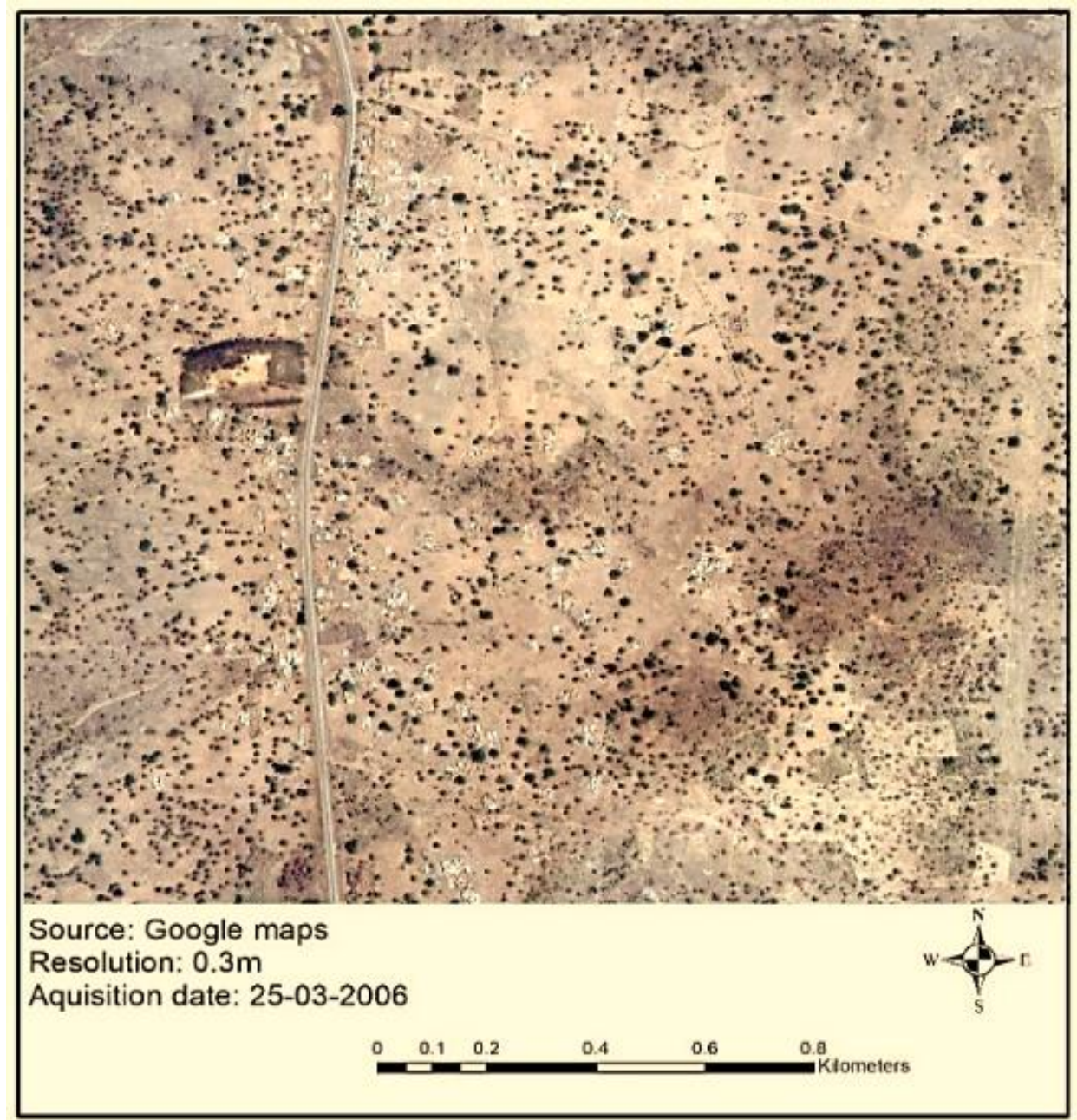

Figure 8 Urban settlement 2006 - Kunfabiala at the fringe of urban Wa 


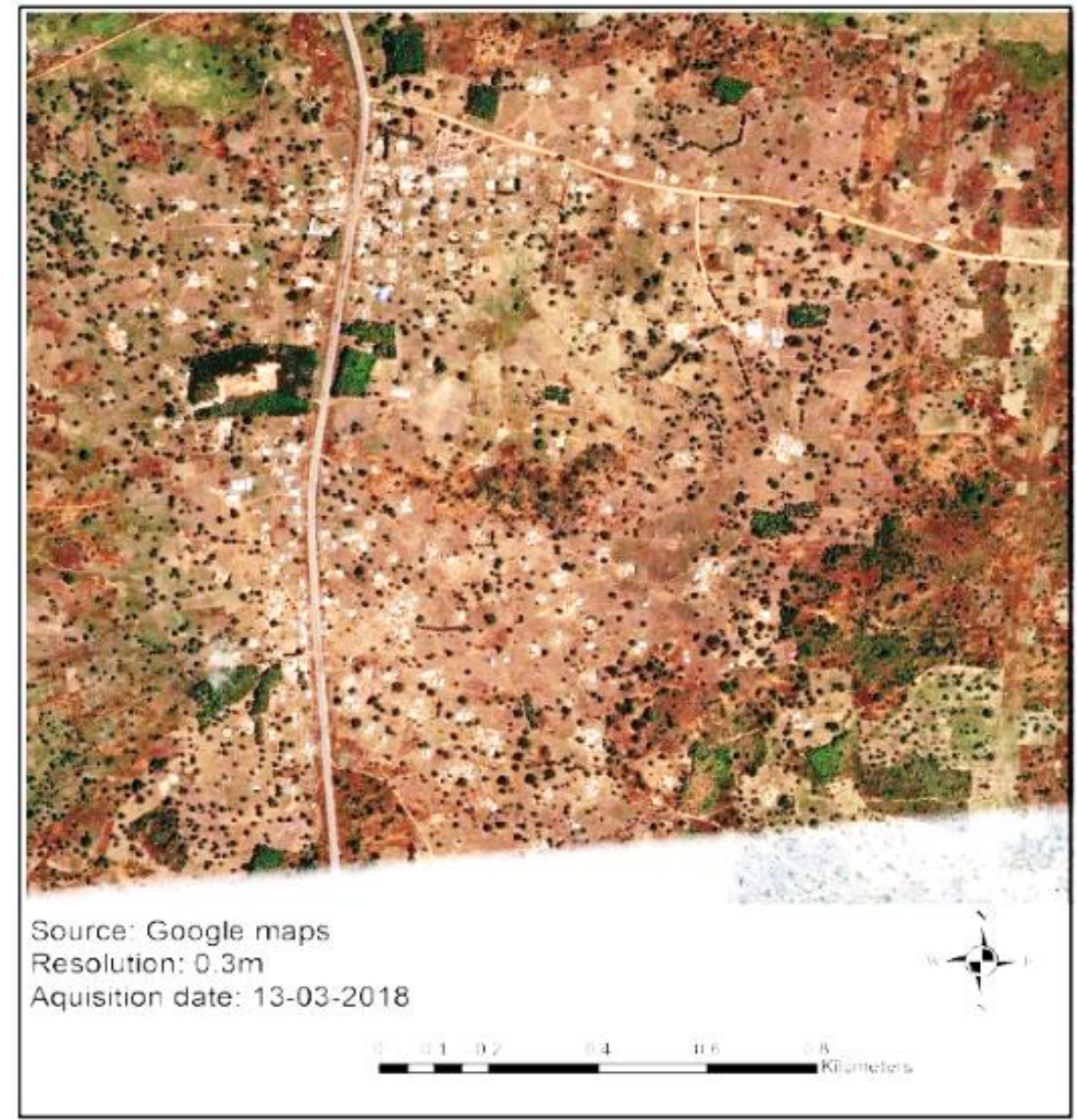

Figure 9 Urban settlement 2018 - Kunfabiala at the fringe of urban Wa

The key factors for land rights variations between rural and urban areas, the FGDs mentioned, have some influences of population growth and urbanisation but are also attributable to flexibility (fluidity) of customary tenure system, speculation about future urbanisation prospects from land and non-adherence to customary norms. It is also attributed to the absence or weak implementation of tenure laws by statutory bodies including the courts. This influences the disregard for both customs and legislation regarding land, since statutory laws supersede customary norms. This remark during a settler FGD sums it all:

"Fair and speedy determination, and sanctioning of customary land rights violations would restore people's land rights and secure tenure. This is because the 1992 Constitution of Ghana recognises customary law practices and making court judgments on land rights abuses final. Otherwise landowners' unilateral variation of settler land rights over the years deprives us (settlers) of the right to hold land and indeed all other rights therein. This causes us (settlers) to 
resist being removed from our dwelling places and damning the consequences. But we know that these possible conflicts on widening land rights variations will not promote our farming, livelihoods and food security."

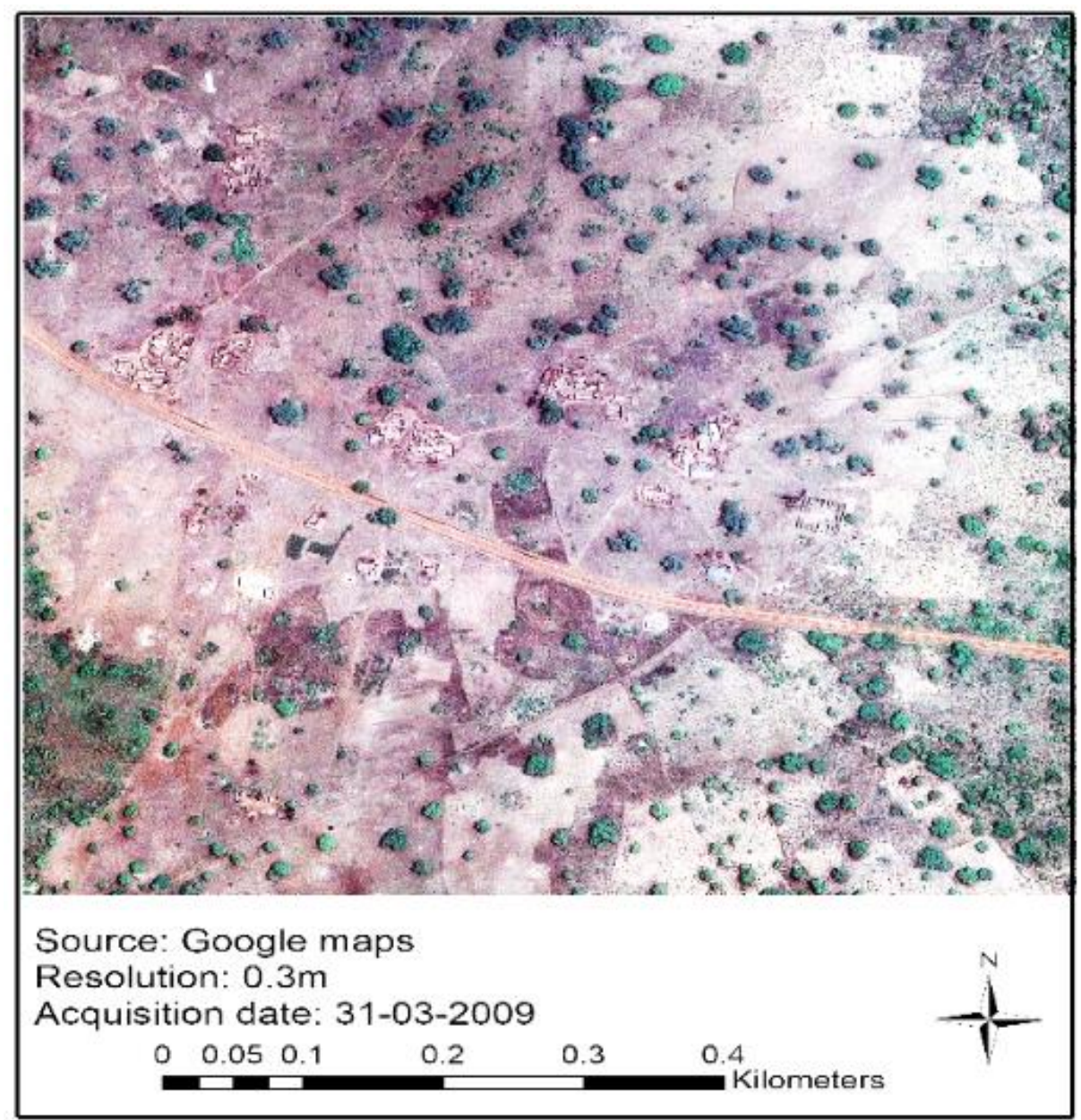

Figure 10 Rural settlement 2009 


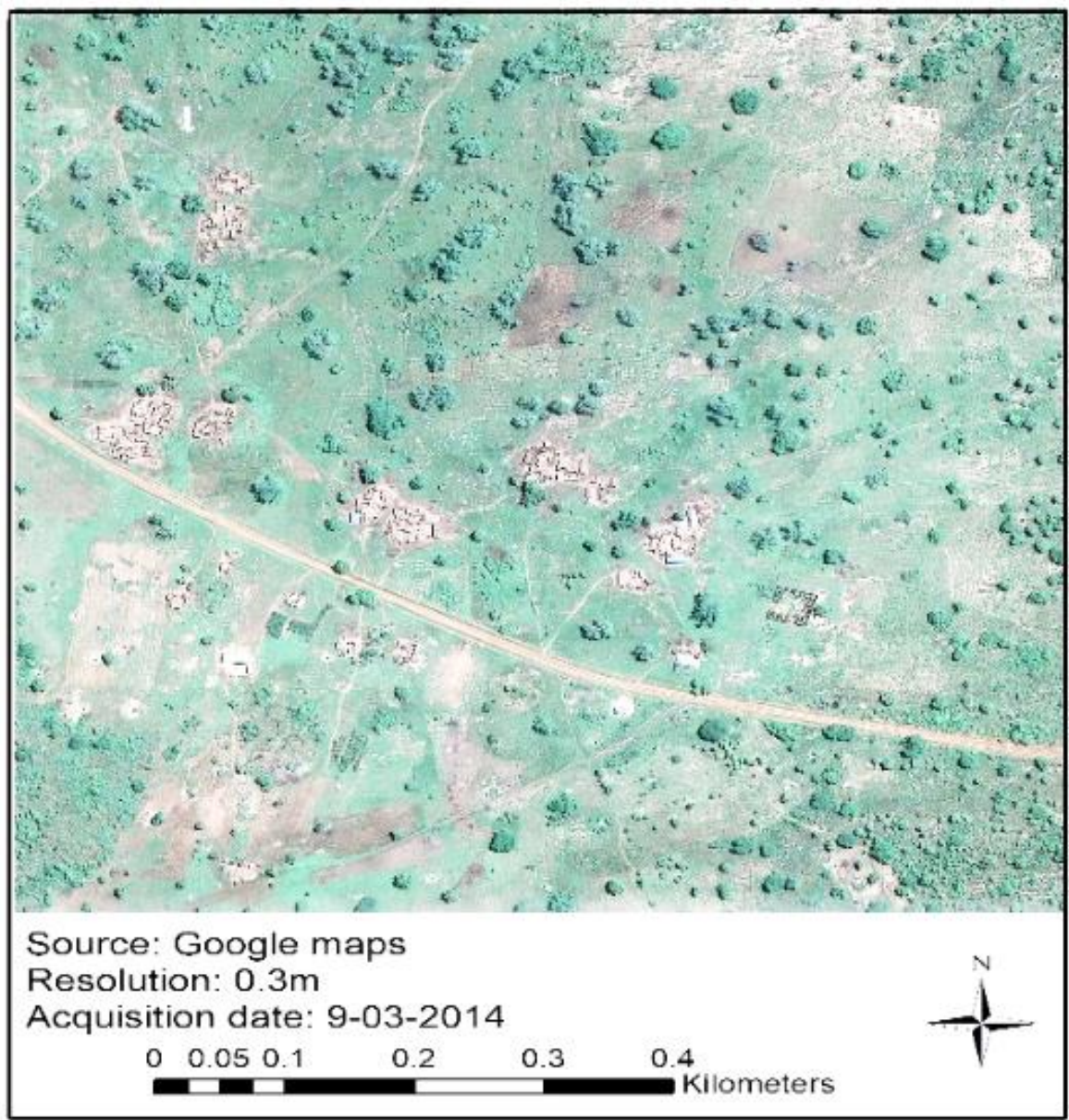

Figure 11 Rural settlement 2014

In all the study areas visited, male settlers claim they had more certain land rights and felt more tenure secure before 1983 when they held up to 10 hectares of farmland than now that they have no farmlands left in the urban areas. Currently, male settlers said they are experiencing changing and weakening land rights and can hardly be guaranteed tenure security for their needs let alone transfer land rights to their heirs. A settler remarked that:

"Not all of us can go to school, not all who attend school do complete and not all who complete can create or get a job hence the need for land/farming rights will remain for a very longtime. At least that is needed to provide for our basic food needs in the household and sell the surplus in the market to obtain some income (remember many of us do not have any other skills apart from farming). Farming remains important not only to farmers but also to those who are selling and building on the land. So, help us reach some understanding with our landlords for the good of all into the future." 


\subsubsection{Age and land rights variations}

Regarding other considerations in all the communities visited, the respondents stated that customary land rights do not consider age. They clarified that it does not therefore matter whether one is young adult and middle-aged or an elder. They added that what matters in determining customary land rights, farm sizes and tenure security is status (i.e. landowner or settler) and sex (i.e. male or female). The respondents stated that land related decision-making in the past did not sufficiently involve the young adults and middle-aged. However, the growing assertiveness from young adults and middle-aged was observed (during the data collection) among both landowners and settlers. Throughout, the young adults and middle-aged took part in all land related discussions held with the elders. Irrespective of age, all categories of males have equal rights to land as shown in Table 4. Similarly, all the females (i.e. whether young or old) have fewer rights than all males in the continuum of land rights as again shown in Table 4.

The range of customary land rights in the study area as shown in Figure 12, was compiled as inspired by du Plessis, Augustinus, Barry, Lemmen, (2016) in the continuum of rights. These authors indicated that the continuum of land rights refers to the diversity of tenure arrangements in practice, encompassing both de facto and de jure rights. While the rights in this range may not fully enjoy the benefits of formal administrative or legal recognition, the social recognition is high, making de facto rights locally legitimate. They continued to say that a continuum of land rights exists when a land management system includes information that caters for the whole spectrum of rights including customary. From the extreme left of Figure 12, respondents mentioned that landowners also experience land rights and tenure insecurity with other landholders like settlers and women. In addition (towards the extreme right of Figure 12), landowners solely experience certainty of duration, unlimited decision-making on their land and enjoy tree-rights.

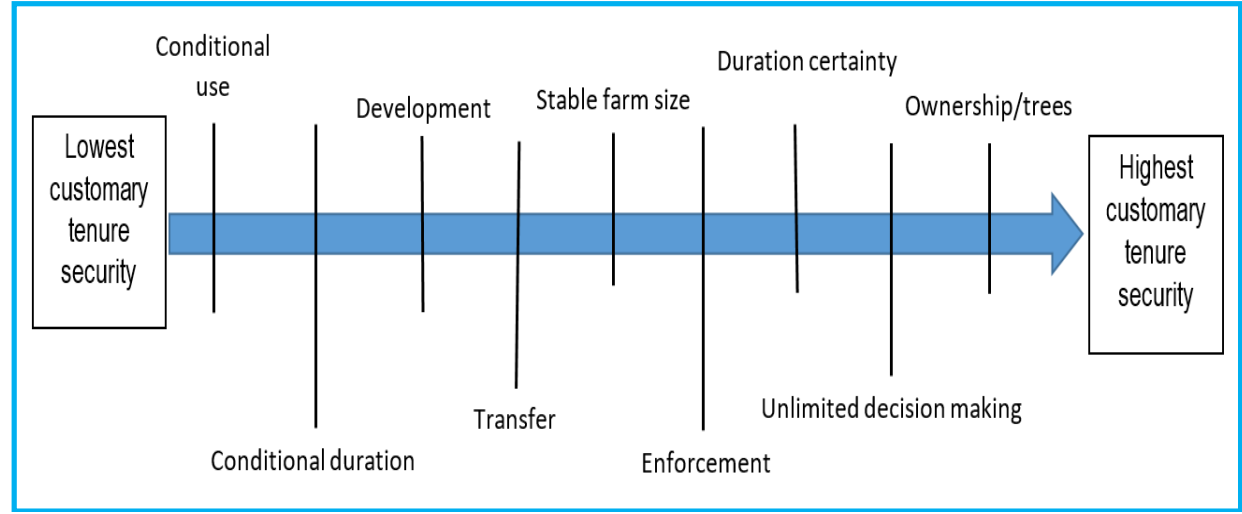

Figure 12 Range of customary land rights \& degree of tenure security in study area. Source: fieldwork, (2019) and adapted from Lemmen et al., (2015).

The research respondents indicated that land rights to use, develop, make decision, transfer, be sure of duration, enforce, own etc. held by male landowners, have higher tenure security than those held by male settlers and 
women in general as shown in Figure 12. One male landowner from Piina said that:

"the strength of land rights or tenure security depends on who (landowner or settler and male or female) holds the land but not the name of the land right itself. For this reason, he continued that a use right for a male landowner is different i.e. stronger than that for male settler or females. For instance, he added "all women and male settlers also possess use, transfer, development and freehold rights but with limited certainty" (i.e. lowest customary tenure security)." [This is also contained in Figure 12]. "On the contrary," [another added that] "we (male landowners) have higher land rights certainty and have the freedom to decide on whatever to do with it [within the bundle of rights] than others (like male settlers and females)."

Also, the respondents said that land ownership is exclusive to male landowners as contained in Figure 12. In some communities in the study area (particularly Piina), being a landowner is equal to possessing tree rights. A male landowner from Piina therefore boasted that:

"if you do not have land then on what or with whose authority can you plant a tree except the landowners' authority? We know that this particular land right which controls planting and felling of trees can have soil fertility, increased food production and food security implications too. That is why we entreat all non-landowners (especially settlers) to seek our consent before planting trees otherwise it is a sign of disobedience to us landowners and for which reason we will sanction them. The sanctions can include outright ejection from the land".

A male settler from Kunfabiala mentioned that:

"Land rights are insecure for we secondary rights holders because for us settlers our rights enforcement is subject to male landowners' involvement."

A "landowner female" from Sing said that

"we women suffer more than men because we entirely must rely on our male relatives otherwise we cannot access land, talk less of strengthening our rights and securing land tenure in general. Meanwhile, any male can directly approach male landowners without any other intermediary to access land. The tenure duration of females (daughters and wives) of the landowning group is also quite uncertain and dependent on the soundness of our relationship with the males. Thus (most, not all) women's land can be taken away at any time without any customary limitation especially in the rural areas. For us females, we can better enjoy our land rights by virtue of our marriage into or bearing children for the landowning family member."

Furthermore, another "landowner female" from another focus group discussion added a caveat to women's land rights in a patriarchal system:

"our land rights are stronger and our land tenure more secure after the death of our husbands if we have sons for them before their death. But our land rights are weaker if we have only daughters and further weakened with no children or when our daughters grow up and marry. Women's land rights and 
tenure security may therefore weaken at widowhood and can cease to exist at divorce. However, women (widows) who remain unmarried in the late husband's house, customarily have full use (not ownership) rights. Therefore, any family member (male or female) must seek her permission to use any part of it, even though we may rarely turn down such requests. But this is unlike the urban areas in Ghana, where the situation is only a little different in the sense that the legal regime on land rights is gender neutral regarding formal leases but not on customary practices. This seems to give women the liberty to purchase land for building and agricultural investment purposes. Meanwhile, women in need of land in either urban or rural areas still have to be led by a man otherwise the male landowners will be apprehensive, and we may not succeed in accessing the land."

\subsubsection{Variations of customary land rights based on disability}

Implicit in the discussion with the focus groups is the fact that there was no variation/inequality between abled-bodied and disabled people on land rights and tenure security. Except to say that people without the ability to farm become automatic dependents on their next of kins who absorb their farmland as well. However, they said if these disabled persons beget heirs in the future, their dependents automatically inherit their father's land when they grow up without any customary inhibition. Therefore, land rights variations affect the disabled people on the basis of their landowner/settler status or gender but not their disability.

According to the settler elders for instance, one of remarked that:

"Land rights are similar irrespective of disability. It is such that both abledbodied and disabled male landowners' rights differ from that of male settlers which is also different from all females."

\subsection{Discussion}

This discussion dwells on the nature of land rights variations based on status (landowners and settlers), sex (males and females) and location (rural and urban areas). These variations are discussed using the social structure theory, defined as the patterned relationships between people from different components of society such as class, status (ethnic origin, sex), roles (landowners), groups (young adults and middle-aged, disabled, aged), and institutions (family) that persist over time. As mentioned in 2.1, Tirole (1989) establishes that there is in-built inequality in the hierarchy of social structure which makes some groups receive less resources including land, its rights and tenure security than others. The social structure determines what and how much resources who gets including the associated rights. The disadvantaged from particular groups are subjected to cultural biases within the social structure with limited (land) resource rights regardless of their individual qualities as reflected in the discussion below. Exceptions to the theory have been discussed as well regarding age, disability and land rights.

\subsubsection{Variations of landowner and settler land rights}

The results in Figures $6 \& 7$ show that from over 10 hectares of farming area for male settlers in 1983, their average farm size today is five times smaller, 
that is approximately two hectares. Landholding of male landowners has similarly reduced but by about half i.e. from over 10 hectares in 1983 to four hectares in 2018. Meanwhile, the general population growth trend in Ghana indicates that the country's population rose by three times from 12.3 million in 1984 to an estimated 30 million in 2019 (Republic of Ghana, 2012). Further reports from (GSS, 2012; Republic of Ghana, 2014) reveal that Ghana's rural population and rate of urbanisation is slower with the study region (Upper west) being the least urbanised. From the above information, it is evident that the reduction of male landowners' landholding seems to correspond to the trend of population increase (i.e. three times) while that of settlers does not (i.e. five times). This suggests that other factors may be influencing variations of farm sizes, land rights and tenure security in the area besides population and urbanisation.

Similar to the work of Toulmin, (2008); Chauveau, Cisse, Colin, Cotula, Delville, Neves, Quan, Toulmin (2006), there are inequalities of land rights held by different categories of people largely based on the social structure in customary settings including the study area. These land rights variations have tenure security and related implications for livelihoods especially food security of the predominant smallholder farmers. These variations were identified by FAO (2002), where access to land is often related to social identity. In this study, customary land rights of various groups are based on ethnic identity or status as indigenes (landowners), non-indigenes (settlers) or sex (male or female). For instance, the most common land right available to nearly everyone in the community is "use" right but while male landowners have unrestricted use, male settlers are limited to growing food crops without access to "tree rights" (whether to plant or cut). Further to that, women are reported to be limited to growing mostly vegetables and groundnuts. This study found that similar to the findings of Nara et al., (2020), the current land rights inequalities and consequent tenure insecurity have wide farming and food security implications on male settlers and all females compared to male landowners in northwest Ghana. This is also in line with the work of Bugri (2008), who found that while male landowners said non-tenurial challenges of insufficient farming inputs account for low food production and food insecurity, non-member landholders (e.g. settlers) attribute their food insecurity largely to weak customary land rights and tenure insecurity.

Population increase is said to have directly or indirectly affected existing rights of people already in occupation of land. This is irrespective of whether that land occupation is permanent or temporal (e.g. nomadic) as has been observed in other studies (FAO, 2002). Literature generally abounds that land rights are transforming i.e. weakening according to Cotula \& Mathieu, (2008); Toulmin (2008) and this research shows that consequently, farm sizes are also transforming (reducing). These therefore weaken land rights and cause tenure insecurity with implications for smallholder farming. If such trends continue, household food security can worsen while disagreements between male landowners and male settlers may increase and disrupt peaceful co-existence and development in general. 
The new realities following land rights transformations as expressed by Knight (2010) and reduction of farm sizes are increasing commercialization of rural lands creating uneasiness among settlers and raising community tensions. Male settlers have expressed the possibility of degeneration in social order and rise in social vices of crime and prostitution among young adults and middleaged in the study area. Based on the above and in agreement with the findings of Biitir \& Nara (2016), there is suspicion and mistrust between some male landowners and male settlers. For this reason, one settler farmer from Kunfabiala remarked for instance that, "there is nothing to live for with worsening land rights variations, tenure challenges and food insecurity." Settlers further said they sometimes have to disregard customary rules in order to survive otherwise male landowners would have evicted them long ago. Male settlers added that they do not care about contravening formal land laws under current circumstances because the courts which remain final arbiters in all disagreements including land issues, are slow to settle their land rights challenges. This position agrees with the findings of Gyamera (2018), that there is delayed land justice delivery in the courts in Ghana.

On one hand, the social structure theory is relevant for analysing this topic because the tenets of the theory are similar with the manner of land rights allocation in the study area. For instance, privileged male landowners (who are high on the social ladder/structure), have absolute land rights superior over those of underprivileged male settlers and all females. On the other hand, contrary to the theory, some groups like young adults and middle-aged (not on top of the social ladder/structure) were found not to influence land rights variations because they possess equal customary rights like the elders. Also, disability (that may place people low on the social ladder/structure) in the study area does not cause any inequalities in land rights as the disabled were found to possess similarly equal rights as their able-bodied male landowners, male settlers or female counterparts. Other findings from the operationalisation of the social structure theory in the study area are discussed next.

\subsubsection{Gender land rights differences}

Ubink's (2018) case studies in northern Namibia and Ghana demonstrate that when programming ignores issues of power and empowerment to resources like land, it will not have the hoped-for positive impact on vulnerable groups. Women generally, have been found in this research to possess weaker rights to land, regardless of whether they come from settler or landowner groups. The twist is that, landowning females (higher on the social ladder/structure in the study area) are in a worse position than male settlers in terms of land rights. But this is rather unexpected as it means that they (landowner females) are being discriminated against, using the customary land rights norms and practices on "their lands". Customary land rights and tenure are therefore more insecure for women than men whether they are settlers or landowners as supported by Duncan \& Brants, (2004); IFAD (2015); Lengoiboni et al., (2019). According to Toulmin, (2008), women are particularly vulnerable to dispossession because they lack power and rights of inheritance which agrees with the practices under the patriarchal system in the study area. 
Female land rights allow them to access customary land through their male relatives and so they cannot independently secure their rights or tenure. Therefore, in spite of the non-discriminatory legal regime as opined by Duncan \& Brants, (2004), historical and customary practices still obstruct females to a large extent since the legal regime has not adequately dealt with customary inhibitions on women's customary land rights. This inequality of land rights against women affects their farming in terms of planning, investment and production. It is therefore a disincentive for women's effective participation in farming to promote food security. Meanwhile in Ghana, women constitute over $51.2 \%$ of the population and about half of them in agricultural activities (Republic of Ghana, 2014). The findings in this paper are similar to the tenets of the social structure theory where women belong to a marginalised group in society. However, the disadvantaged land rights of landowner women against the tenets of the social structure theory calls for a closer attention to inherent (may be systemic) discrimination against specific groups. Largely, males in the study area can withhold women's land right to access. This kind of situation is what Doss \& Meinzen-Dick (2018) therefore describe as "tolerated use but not a right."

Much more than that, the fact of women belonging to one of the most disadvantaged groups in the setup of society has been amplified in this research. This study found that based on their position on the social structure, indigene women from the landowning group should possess superior land rights at least, next to indigene male landowners over non-indigene male settlers and female settlers. Paradoxically, females within the landowning group have weaker land rights than male settlers and equal to female settlers with the weakest land rights. In other words, and in general terms, male landowners can change or withhold all of women's land rights in the study area and yet not go against custom. This further reveals profound complexities in the applicability of the social structure theory and the associated rights as other factors can affect a privileged group like female landowners because of femininity. The respondents clarified that in spite of the seeming weak land rights of all women, those from the landowning group are relatively better off. The reason is that female landowners' source of land and land rights is from the male landowners meanwhile, male landowners' land rights are clearly stronger. This means that women from the settler group are much worst off because their source of land and land rights come from male settlers who obviously possess weaker rights than male landowners.

In spite of this reality of weak land rights and insecure land tenure of women, Nara et al., (2020) revealed in a related study that all the females indicated that under this patriarchal inheritance system, they (women) prefer to entrust (through transfer) their land to their sons but not their daughters. The women's reason is that when daughters in the patrilineal system marry, they go under the authority of their husbands in all matters including land. As a result, daughters after marriage will not be able to preserve the customary ideals of land rights and land tenure of a patriarchal system as compared to sons. The dictates of the patrilineal system therefore underpin weakening land rights of women, which women themselves uphold willy-nilly. 


\subsubsection{Rural and urban land rights variations}

The spatial changes observed over the period between 1983 and 2019, show expanding built areas. These changes invariably influence reduction of farmlands as corroborated by the FGDs. This understanding of LULCC patterns can inform the nature and direction of policy in terms of town planning, land distribution and consequent land rights and land tenure issues in a more equitable manner. It therefore agrees with the position of Kamwi et al., (2018) about the usefulness of spatio-temporal LULCC patterns in equitable land management in Zambezi region, Namibia. There are reported weak land rights, reduced farmlands and customary tenure insecurity in both rural and urban areas among various groups. However, in both rural and urban areas, male landowners' rights and farm sizes are similar and stronger than male settlers and all females. This is despite the minimal physical expansion of settlements in the rural communities as few physical changes could be observed in terms of new buildings. Immigration and urbanisation directly contribute to land rights and tenure changes in the urban areas but they also played an indirect role in the rural area in line with findings of Chauveau, et al., (2007); Dembitzer (2014); Jacob et al., (2006). Also, general economic and commercial transformations over time in the work of Naab et al., (2013) influenced and quickened already existing internal mechanisms of land rights and land tenure changes in the rural communities studied. Lands in the urban settler settlements have been demarcated and sold out to private developers pressured by urbanisation as contained in literature. The nature of the customary tenure system in place and the anticipation of rural lands assuming higher values in the future also influences customary land rights variations and tenure insecurity in the rural parts of the study area. It therefore implies that a combination of external factors according to Dembitzer, (2014) and Simbizi, (2016) and internal factors as observed by Cotula \& Mathieu, (2008); Ghebru \& Lambrecht, (2017) account for changes in customary land rights and tenure insecurity. The factors are urbanisation according to Cotula \& Neves, (2007), population growth emanating from immigration according to Dembitzer, (2014), and global economic growth trends characterised by commodification of land (Naab et al., 2013). These external factors may be considered to directly impact urban parts of the study area. The nature of the tenure system and its internal fluidity concluded by Chauveau, Cisse, Colin, Cotula, Delville, Neves, Quan, Toulmin (2006) in terms of customary norms and practices and the weak enforcement of land laws, facilitates customary tenure insecurity in northwest Ghana. The unannounced and often unilateral changes imposed on land rights of all women and male settlers in both rural and urban areas influence land rights and tenure security. The ease of varying customary tenure with little or no consequences, coupled with weak legal enforcement of land rights especially in rural areas, also cause increasing land rights variations and tenure insecurity. This affects all women and male settlers much more than male landowners as discussed above.

Additionally, there is potential for land renting or/and sharecropping to mitigate tenure challenges as observed by Platteau, (1996) in both rural and urban areas. This is both for land rights equality and to reverse the impact of farm size reduction. Some male landowners said they are willing to try land renting and sharecropping if settlers are also willing to participate. Thus, the 
isolated idea of land renting, though not the absolute solution to land rights and tenure security challenges in the area, is one way of ensuring land access, rights and tenure security.

Other threats to fair/equal land rights and tenure security are that there are no definite policies or plans to engage in committed and appropriate land documentation of customary land rights (Abubakari et al., 2018; Gollin, 2014). This may maintain or increase land rights variations and threaten tenure security of vulnerable groups like smallholder male settler farmers and all women. In both rural and urban areas, the customary tenure and service arrangements in their current form cannot provide the needed land rights and tenure security as contained in Jacob et al., (2006). It is especially true for succeeding generations since they can be manipulated by some individuals according to Chauveau, Cisse, Colin, Cotula, Delville, Neves, Quan Toulmin (2006). This can cause further land rights inequalities and tenure insecurity in the future. Especially when the current partakers of past agreements pass on and their heirs take over without any verifiable (documentary) evidence on their land transfers to refer to. Agreeably, the current oral narrations on land transfer arrangements and agreements by one group can be disputed in future.

Low administrative capacity according to Abubakari et al., (2018) and absent legal backing of the Customary Land Secretariats, also seem to aggravate land rights variations and tenure insecurity among vulnerable groups as contained in Biitir \& Nara, (2016); Biitir, Nara, \& Ameyaw, (2017); Nara, Mwingyine, Boamah, \& Biitir, (2014). Abubakari et al., (2018); and Lengoiboni et al., (2019) further stressed that there is a mismatch between customary law and statutory law in Africa, which also affects state intervention and facilitation to protect and strengthen land rights and secure tenure. These inconsistencies between customary and statutory land rights, can undermine fundamental land rights recognition for tenure security (Abubakari et al., 2018; Lengoiboni et al., 2019). All these insights put the state in a central position to coordinate activities, institutions, resources and practices to make local people renegotiate, recognise and record the varied land rights in the study area in particular and other affected areas in the country in general. When governments do this, then there can be less challenging land rights variations and increased land tenure security that promotes all forms of investment and associated benefits for local and national development.

It was evident that less adherence to and poor enforcement of land laws in Ghana's courts (with numerous unresolved cases) is also a contributory factor to the growing disregard for people's land rights especially under customary arrangements. Gyamera (2018) stressed that 'land cases pending in Ghana's courts constitute about $59 \%$ of all court cases while the settlement rate is only $10 \%$ over all. These delays from the courts have for instance, contributed to lingering tenure disagreements and insecurity for more than five years between some groups in the study area. Both landowners and settlers in the disagreement cannot completely utilise their rights on the disputed land as long as the case remains undetermined by the court, especially if the court places an injunction on it. In this way, land rights variations will deepen against the most vulnerable - women. It was evident that unlike sex- and status-based 
land rights variations in the study area, disability- and age-based land rights variations were virtually absent and not permitted by custom in northwest Ghana.

The results generally fit into the framework of the social structure theory with the exception of the few contradictions raised earlier, on young adults and middle-aged and disability neutrality on land rights in northwestern Ghana. In addition, is the inconsistent land rights of women from landowner groups getting less than expected, in spite of their 'privileged position in the society as indigenes.'

The tenets of the social structure theory cannot fully assure different groups of their land rights based on the above analysis. Useful options to minimise land rights variations and secure tenure of all landholders needs to be developed in further related studies.

\subsection{Conclusion and recommendations}

This study aimed to assess the nature of land rights variations using the social structure theory among smallholder farmers in customary areas of northwest Ghana. The exploratory research method was used to address these questions: i) What is the landowner-settler inequality in the bundle of land rights? 2) What is the nature of gender land rights variation within the social structure? 3) How does customary land rights variation/inequality affect various categories of people in rural and urban areas?

Results show that customary land rights and land tenure are unequal among different categories of smallholder farmers in the area. Also, speculations on future land value appreciation, manipulation of undocumented male dominated customary land laws and practices, and absence of legal backing or unclear role of Customary Lands Secretariats including poor coordination with Lands Commission seem to influence land rights variations and tenure insecurity besides urbanisation and population growth. The rest are inadequacy of relevant laws, poor implementation of the few available laws and inability of the courts to speedily and effectively adjudicate on land rights and tenure related disputes. Currently, the settler or feminine status tends to hinder land access, rights and tenure security. And finally, access to financial power has become an important influence in accessing land and benefiting from its related rights. Moreover, women still face cultural obstacles under circumstances beyond their control (as mentioned earlier in literature) like widowhood, divorce, childlessness and bearing only female children. Oral tradition on customs, norms and practices have currently been disputed by local people themselves for which reason they suggest re-sensitisation or self-reminders together with seeking legal and other alternative solutions to their land rights challenges.

This study concludes that over the past, governments may not have properly managed customary norms governing land as contained in literature and revealed by respondents. Even though the formal legal system has finality in land matters, it is constrained by some ambiguities to be speedy and effective. 
Besides, without adequate financial power, the court option does not give poor people the confidence to legally contest and secure their land rights. This study was conducted in one region so the results largely represent the study area yet, other parts of Ghana and beyond can find it useful. However, further studies will be necessary to guide local people re-negotiate their land tenure, narrow land rights variations/inequalities and ascertain which aspects of this study will be easily applicable in other areas. Some important questions raised by this research for future research include: what are the implications of land rights and tenure security inequalities, how can these be reduced to protect others' rights. 


\section{Chapter 3 Implications of customary land rights inequalities for food security: A study of smallholder farmers in northwest Ghana}

Implications of Customary Land Rights Inequalities for Food Security: A Study of Smallholder Farmers in Northwest Ghana

Baslyd B. Nara, Monica Lengoiboni and Jaap Zevenbergen

https://doi.org/10.3390/land9060178 


\subsection{Land Rights and Tenure Security}

Land tenure is governed by social relations and institutions (formal/statutory/legal and local/ customary) determining access to, use and transfer of land contained in a bundle of rights available to various categories of people (Maxwell \& Wiebe, 1999). Land rights are the entitlements (within a tenure arrangement) to land based on land law, custom, or both. Such land rights are indispensable for people who depend on them for their survival. For example, the right to access, hold and use land makes it available to people and enables them to engage in productive activities including farming (Deng, Yan, \& Xu, 2020). These land rights may derive from statute law, custom or both, marriage, power and inheritance. However, such rights can be significantly varied leading to inequality (Maxwell \& Wiebe, 1999).

According to Wegerif and Guerena (2020), land inequality represents the differences in the quantity and value of land people have access to, the relative strengths of their land tenure rights, and the appropriation of value derived from the land and its use. These researchers added that land-related inequalities in developing countries affect everyone and directly determine the quality of life of smallholder or subsistence farmers who depend on land and its related resources for their livelihoods and even survival (Azadi \& Vanhaute, 2019; Lipton \& Saghai, 2017; Morton, 2007; Wegerif \& Guerena, 2020). Meanwhile, land inequalities also inevitably result in weak land rights for some. Therefore, one cannot adequately strengthen the land rights of weaker groups without overcoming land inequalities in general. This is especially true with increasing pressure on land evidenced by farm size reductions and displacement of vulnerable smallholder farmers and groups. Zant's work - Zant (2005) identifies that smallholders in developing countries produce most of the food crops for home consumption and some cash crops for the market. Such farmers require strong land rights with secure tenure to continue. The United Nations (UN) also acknowledges that substantial land rights inequalities exist and have implications for farming, food security and poverty reduction (FAO, 2014).

It is argued that while ongoing challenges over property rights, inequality, and the political economy of land distribution persist, they can be overcome (Azadi \& Vanhaute, 2019; Myers Gregory, 2013). This probably informs the UN's resolve to promote improved land rights, greater agricultural production and improved food security in its Sustainable Development Goals (SDGs), particularly goals 1.4 and 2.3. Land rights inequalities are typically widened and deepened by factors such as gender, ethnicity, class and political affiliation (Myers, 2013). Land rights inequalities and the resulting tenure insecurity contribute to food insecurity. This is because both rights and tenure security,

This chapter is based on a contribution in a book chapter - Responsible and Smart Land Management Interventions - An African Context. by Francis and Taylor Group titled: Influences of Community Land Rights and Tenure Security Intervention Processes on Food Security in Northwest Ghana Baslyd B. Nara, Monica Lengoiboni, and J.A. Zevenbergen 
can enable efficient, profitable, and sustainable agricultural production and access to food, where the landholder has sufficient power over the land (Maxwell \& Wiebe, 1999). In related research (Chauveau, Cissé, Colin, Cotula, Delville, Neves, Quan, 2007; Kidido et al., 2017; Obeng-Odoom, 2012; Chauveau, Cisse, Colin, Cotula, Delville, Neves, Quan, Toulmin, 2006; Wegerif \& Guerena, 2020), the authors posit that land rights are skewed against the majority of farmers, indigenous people and other communities. The marginalised may be indigenous landowners or settler farmers, males or females, young or old and disabled or able-bodied. Indigenous landowners are naturally the first occupants of any land. Secondary land rights holders (like migrants) refer to those who have arrived more recently whether from other parts of Ghana or beyond (e.g., Burkina Faso). Such migrants, referred to as settlers in Ghana, now permanently reside on that land and have done so for generations. Where land rights holders have little or no control over 'their' skewed land rights inequalities, the implications can be serious and are therefore worth investigating. This research contributes to the customary land rights and tenure literature by describing the context specific dynamics of the implications for vulnerable groups and how these dynamics are shaped in local settings.

\subsubsection{Customary Land Rights Inequalities and Food Production}

Land rights inequalities among different groups feed into the sense that, customary land rights and tenure are secure based on landholders' perceptions (Akrofi \& Whittal, 2011; Bugri, 2008; Chauveau, Cissé, Colin, Cotula, Delville, Neves, Quan, 2007; Mireku, Kuusaana, \& Kidido, 2016). On the other hand, there is a contrary view suggesting that customary land rights (with their inherent inequalities) are insecure due to changes in African economies, including demographic growth, urbanisation, monetisation, livelihood diversification, integration in the global economy, and cultural change (Abubakari et al., 2018; Carte, Schmook, Radel, \& Johnson, 2019; Conway, 2011; Lawry et al., 2014; Naab et al., 2013; Ruerd \& Policy and Operations Evaluation Department (IOB) Ministry of Foreign Affairs, 2011). The inequalities inherent in the social structure of communities may reflect themselves in skewed land rights inequalities, varying tenure security and sometimes landlessness. Additionally, undocumented customary land rights and tenure are known to contribute to weak tenure security (Abubakari et al., 2018).

Land rights inequalities (when skewed) among various categories of vulnerable and marginalised people dependent on them, tend to negatively influence their tenure security and livelihood needs especially in terms of farming and food security (Carte et al., 2019). Land inequalities also invariably seem to result in weak land rights because, if such inequalities are regarded as the norm, privileged people may tend to abuse (relying on weak laws and enforcement) the vulnerable, thereby further aggravating the plight of the marginalised in society. In line with the above assertion, Carte et al., (2019) argue that smallholder farming family migration in Nicaragua and Guatemala represents displacement resulting from land right inequalities and hopelessness. This is of concern because a large proportion of farmers in Africa depend on customary lands and adequate farm sizes for meeting their food needs (Conway, 2011; 
Lawry et al., 2014; Ruerd \& Policy and Operations Evaluation Department (IOB) Ministry of Foreign Affairs, 2011). It is important to recognise that land rights inequalities in the context of this work mean that some groups may have too little land to meet their farming and food needs while others have bigger farms than they need for their survival. As mentioned above, the nature of land rights inequalities, which also reflect varying tenure security, have implications for productive land use such as smallholder farming. This situation may threaten the livelihoods of those who depend directly on the land for their food supply (Gazdar, Khan, \& Khan, 2002). The inequalities inherent in customary land rights and tenure arrangements can affect peri urban agriculture by reducing the land available for farming and therefore, food production and food availability (Chauveau, Cisse, Colin, Cotula, Delville, Neves, Quan, Toulmin, 2006). Meanwhile, most land users in sub-Saharan Africa access land (and of course rights over land) through this customary system that remains contentious regarding the security of inherent rights with negative implications for the poor over time (Nkegbe, Abu, \& Issahaku, 2017; Yaro, 2010). The insufficiency of information about customary land rights therefore leads to calls for evidence in order to help eradicate tenure challenges (Asiama et al., 2017; Lengoiboni et al., 2019; Nkegbe et al., 2017). This research attempts to provide some evidence about context specific customary land rights.

\subsubsection{Food Security and Its Dimensions}

The World Food Summit in 1996 adopted a definition of food security as a situation in which "all people, at all times, have physical, social and economic access to sufficient, safe and nutritious food that meets their dietary needs and food preferences for an active and healthy life." The Economic Commission for Africa regards food security as the capacity to provide sufficient food through production, acquisition and distribution on a sustainable basis (AEC, 2004; Ballard et al., 2013). The above definitions imply that eradicating hunger requires increases in the availability of and accessibility to sufficiently nutritious food in a sustainable manner. The extent to which individuals and families are able to increase their food security depends in large part on the opportunities they have to increase their access to assets such as land (Azadi \& Vanhaute, 2019; Food and Agriculture Organization, 2002; Ruerd \& Policy and Operations Evaluation Department (IOB) Ministry of Foreign Affairs, 2011). Smallholder farmers throughout the world continue to experience displacement from their lands, struggle to remain viable and often experience hunger (Carte et al., 2019). According to the Food and Agricultural Organisation (FAO), factors that enable progress towards improved food security and nutrition goals are agricultural productivity growth, functioning markets, and effective social protection (FAO, 2015). This makes land, its rights, associated inequalities, and varying tenure security important in this research. Furthermore, the food needed to boost global food security will come from both large-scale commercial and small-scale agricultural activities (Conway, 2011; Federal Ministry of Food and Agriculture (BMLE), 2015). The supply of food to smallholder households is mainly through own efforts in addition to some purchases from the market of what they do not produce and paid for, by selling some of their own farm produce. 
In Andersen's work, the four pillars of food security are characterised (Rykiel et al., 2011). Food availability implies that food must be physically available in sufficient quantities and on a consistent basis through production and stock (FAO, 2015). Secondly, it recognises food accessibility as the ability to regularly acquire (or receive) adequate quantities of food through purchase, barter, gifting, borrowing or food aid. Thirdly, effective food utilization implies that food must have a positive nutritional impact on people. Finally, food stability is the maintenance of the desired properties or nature of a food over time such that it remains safe and pleasant to consume. It is argued that food security can be greatly facilitated when access to land, land rights, and tenure security are guaranteed, leading to increased investment in farming especially in sub-Saharan Africa (Nguyen, 2014); Ruerd \& Policy and Operations Evaluation Department (IOB) Ministry of Foreign Affairs, 2011). This is especially so for smallholder farmers who depend directly on the land for the majority of their food production and supply. The availability and accessibility dimensions of food security are especially relevant in this research, although without losing sight of the stability and utilisation components. The German Federal Ministry of Food and Agriculture recognises broad implications for food insecurity that land rights inequalities and tenure insecurity can contribute to (Federal Ministry of Food and Agriculture (BMLE), 2015). The evidence in the literature suggests that strong land rights and tenure security are essential for food security (Bugri, 2010; Cotula \& Mathieu, 2008; Lawry et al., 2014; Ruerd \& Policy and Operations Evaluation Department (IOB) Ministry of Foreign Affairs, 2011). Of course, this does not necessarily imply that favourable results from strong land rights and tenure security will automatically result in food security. Instead, some other factors or inputs must be combined with strong land rights and secure tenure, which may then lead to improved food security outcomes and can have positive impacts on the lives of those who depend solely on land for survival.

This paper contributes to the ongoing debate about how customary land rights and tenure security of smallholder farmers may influence household food security. And how it can possibly also affect national and international land rights and food security efforts. What is happening in the study area is relevant for Ghana in the sense that whereas the country may be doing well in terms of food security, its (five) northern regions remain the most food insecure place in the country (FAO, 2015). This food security twist is undermining the country's long-term food security goals.

The organisation of this work is as follows. The introduction has discussed the literature. The key topics are land rights and the consequent variability in tenure security, customary land rights inequalities and food security and its dimensions. Section 2 discusses the research methods. Section 3 presents the results while Section 4 contains the discussion followed by conclusions and recommendations.

\subsection{Methodology}

This is largely a qualitative study that used focus group discussions (FGDs), interviews with key informants and with individuals in key organisations to collect data. The choice of a qualitative study in this research stems from the 
desire to focus on the lived experiences and views of the participants. The methodological focus is not on the number of people affected but on the various outcomes currently experienced by the affected communities. However, the discussions have produced some statistical data, which have been included in the results. Heads of landowner and settler groups provided information as key informants that others in the study communities may not be privy to. Finally, institutions such as the state's land sector agency (Lands Commission) and a collaborative traditional-formal customary land management body, such as the Wa Central Customary Lands Secretariat (WCCLS) were interviewed. A representative of Meridia Ghana that focuses on helping local people document their land rights was also interviewed online.

\subsubsection{Description of Study Area}

The map below shows the location of the study area. The research selected the Upper West Region (referred to in this research as the northwest) of Ghana. The study area comprised the six communities all located in the map in Figure 3 . This part covers a total land area of about $3600 \mathrm{~km}^{2}$. These communities were purposively selected because they have the highest $(80 \%)$ occurrence of farmers holding secondary land rights under the customary system. Customary land rights inequalities, variability in tenure security and customary service arrangements are all usually based on the customs of particular communities in Ghana. These are briefly stated below (Djokoto and Opoku, 2010):

Allodial title: the highest interest in land, communally owned by members of the landowning group. Customary freehold or usufructuary interest: family land use rights held perpetually by members holding the allodial title. Common law freehold right: acquired through express grant from the allodial owner or customary freeholder, either through sale, gift or other arrangements, and usually held by non-members. Leasehold, sub-leases and customary tenancy rights.

Another reason for the choice of these communities is the uniqueness of their land tenure system as compared to those prevailing in the rest of Ghana. The land tenure system in the study area is patrilineal (male controlled), and uses cropping arrangement for non-members, but not sharecropping as commonly found in southern Ghana. In the sharecropping system, land users may give the landowner a half or a third of the crop or its value. However, under the cropping arrangement, land users may offer a 'token gift' of negligible (noncommercial) value to landowners to acknowledge the landowner and settler statuses on the land.

The areas visited include the Sing and Kunfabiala communities in the Wa Municipality of the Upper West Region of Ghana. This area is approximately $235 \mathrm{~km}^{2}$ and the most urbanised part of the study area. The other two rural places, located further north over $200 \mathrm{~km}$ away, are: Piina number (1) and Piina number (2) in Lambusie-Karni $\left(1,360 \mathrm{~km}^{2}\right)$ and, Fielmua and Nimoro in the Sissala West $\left(2,100 \mathrm{~km}^{2}\right)$ districts. These rural districts border each other with travel distances of about $40 \mathrm{~km}$ from one end of one district to the center of the other. The choice of a rural and urban mix in this research was to determine 
the extent to which urbanity or rurality influences land rights inequalities and any resulting implications.

The population of the selected study communities is over 14,400 . The research selected three landowner and three settler communities who participated in FGDs. They were grouped into males (i.e., elderly male, disabled male and middle-aged male) and females (i.e. elderly female, disabled female and middle-aged female) in Tables 7 and 8 . The elderly is defined as those who are $60+$ years while middle-aged and active working population are defined as those between 18 and 59 years (Republic of Ghana, 2012).

\subsubsection{Selection of Participants for Focus Group Discussions}

In each community, the head of landowners (tendana among Waala in Sing, tengansob among Dagara in Piina number (2) and Fielmua, and tortina in Nimoro and Piina number (1)), was interviewed as the key informant. Other key informants were the heads of settler groups in each of the three settler communities who were also interviewed to provide specific information. Also, key people in two key organisations were interviewed as indicated earlier.

Table 7 Landowner FGD participation - Sing, Nimoro \& Piina no. 1

\begin{tabular}{lllllll}
\hline Landowner & $\begin{array}{l}\text { Male focus } \\
\text { groups }\end{array}$ & Number & $\begin{array}{l}\text { Female } \\
\text { focus } \\
\text { groups }\end{array}$ & Number & $\begin{array}{l}\text { Group } \\
\text { total }\end{array}$ & Total \\
\hline Elderly & 3 & 31 & 3 & 34 & 6 & 65 \\
\hline Disabled & 3 & 29 & 3 & 26 & 6 & 55 \\
\hline "youth" & 3 & 36 & 3 & 35 & 6 & 71 \\
\hline Total & 9 & 96 & 9 & 95 & 18 & 191 \\
\hline
\end{tabular}

The number of participants in each FGD averaged 10. This is in line with the recommended size of a focus group of between eight and 12 participants $[38,39]$. A total of 36 FGDs were conducted and all of them directly moderated by the researcher. In each of the three districts, three landowner groups from Sing, Piina number (1) and Nimoro were interviewed. In addition, three settler groups from Kunfabiala, Piina number (2) and Fielmua were also interviewed with varying numbers of participants as shown in Tables 7 and 8 . There were 18 landowner FGDs with 191 participants and 18 settler FGDs with 197 participants, giving a total of 388 participants for the fieldwork and data collection.

Table 8 Settler FGD participation - Kunfabiala, Fielmua \& Piina no. 2

\begin{tabular}{lllllll}
\hline Settler & $\begin{array}{l}\text { Male focus } \\
\text { groups }\end{array}$ & Number & $\begin{array}{l}\text { Female } \\
\text { focus } \\
\text { groups }\end{array}$ & Number & $\begin{array}{l}\text { Group } \\
\text { total }\end{array}$ & Total \\
\hline Elderly & 3 & 34 & 3 & 35 & 6 & 69 \\
\hline Disabled & 3 & 27 & 3 & 29 & 6 & 56 \\
\hline $\begin{array}{l}\text { Middle } \\
\text { age }\end{array}$ & 3 & 36 & 3 & 36 & 6 & 72 \\
\hline Total & 9 & 97 & 9 & 100 & 18 & 197 \\
\hline
\end{tabular}


The focus group discussions and key informant interviews responded to questions about land rights inequalities that may affect tenure security, crop farming, food availability and the consequent food security trends over the years. The focus group discussions provided information about various land rights inequalities affecting categories of people in each community. These were: 1) number of rights, 2) kind and nature of rights, and 3) how these rights affect people's farm sizes and farming output. The FGD participants also gave information about how land rights inequalities affect crop farming and food availability for each category of people.

\subsubsection{Data Analyses}

Audio recordings were transcribed into written text, following which content analysis was performed to draw meaningful inferences about the relationships and impacts revealed by the study and based on the framework shown in Table 9. The analysis was carried out on the documentation resulting from the data collection exercise by systematically evaluating or interpreting texts, oral communication and illustrations. The research results are presented in tables, and some of the qualitative data collected were converted into quantitative form. Next, identified emerging patterns, trends, and themes were matched according to how various groups' bundle of land rights and consequent varying tenure security impacted on their farm sizes, farming activities, food production, food security, and particularly on food availability and accessibility.

For instance, the trend showed that the fewer the rights of one category of people in the bundle of rights, the weaker these rights are and the more vulnerable such land rights holders are. The implications of land rights inequalities influencing tenure security and disrupting their food production, availability and food security were then analysed to better understand the magnitude of the problem. Other implications of land rights inequalities related to migration and youth involvement in crime such as theft, truancy and sexual immorality identified during the data collection process were also briefly touched on, in relation to food security and overall wellbeing of people.

Table 9 Analytical framework

\begin{tabular}{llll}
\hline $\begin{array}{l}\text { Concepts guiding this } \\
\text { research }\end{array}$ & $\begin{array}{l}\text { Analytical dimensions, categories and } \\
\text { understanding }\end{array}$ \\
\hline
\end{tabular}

Rights derived from local practices through successive generations.

Customary land rights Land rights inequalities Food security

Smallholder farming
The practices in which some have more rights that are stronger while others have fewer and weaker rights.

Food security focuses on availability and accessibility constraints that are likely to influence nutrition and stability.

Smallholder farming refers to subsistence farming but with the opportunity to sell excess produce. 


\begin{tabular}{|c|c|}
\hline Land rights & $\begin{array}{l}\text { Exclusive entitlements derived from accessing } \\
\text { and holding land in either customary or more } \\
\text { formal settings }\end{array}$ \\
\hline $\begin{array}{l}\text { The relation between } \\
\text { formal and informal } \\
\text { rights (institutions) }\end{array}$ & $\begin{array}{l}\text { It is a top-down relationship, in which the formal } \\
\text { statutory institutions led by the Lands } \\
\text { Commission (LC) supervises the customary } \\
\text { institutions through documentation, } \\
\text { concurrence issuance, verification of claims etc. } \\
\text { Informal customary norms and practices may be } \\
\text { regarded by the state as primarily important in } \\
\text { land matters. They are however, still subject to } \\
\text { legal processes administered through the } \\
\text { courts. }\end{array}$ \\
\hline $\begin{array}{l}\text { The dynamic interplay } \\
\text { among various } \\
\text { institutions. } \\
\text { Customary, } \\
\text { statutory/legal/formal \& } \\
\text { mixed feature institutions }\end{array}$ & $\begin{array}{l}\text { CLSs were formed as an improvement of the } \\
\text { customary system as a lands office operated by } \\
\text { landowners with minimal external support. } \\
\text { The LC is the state agency that oversees all land } \\
\text { matters in Ghana. } \\
\text { Private land organisations - Meridia and others } \\
\text { carry out land documentation on a small-scale } \\
\text { for households, families or communities in } \\
\text { Ghana. Such documents are subject to the LC's } \\
\text { approval. }\end{array}$ \\
\hline $\begin{array}{l}\text { The dynamic interplay } \\
\text { between actors and } \\
\text { institutions }\end{array}$ & $\begin{array}{l}\text { The actors/stakeholders include landowners and } \\
\text { settlers, men and women, able-bodied and } \\
\text { disabled, and elderly and middle-aged. such } \\
\text { actors work through the formal and customary } \\
\text { institutions in all matters relating to land - } \\
\text { allocations, rights and disputes resolution etc. } \\
\text { However, the legal authority of the courts and } \\
\text { statutory bodies such as the LC are final in } \\
\text { resolving disagreements. }\end{array}$ \\
\hline
\end{tabular}

\subsection{Results}

The results highlight land rights inequalities and implicit tenure (in)security, derived and analysed from the research objectives. This was then analysed based on the perceptions of their tenure and food security to establish the implications and what other interpretations one can make to draw conclusions for improved public policy.

\subsubsection{Nature of Land Rights Inequalities}

Indigenous landowners (males) in Table 4, were found to possess the highest number of land rights (i.e., 14 out of 15). Male settlers were next, possessing seven out of 15 land rights. However, females, irrespective of whether they are attached to landowner or settler groups as wives, sisters or daughters generally possess the lowest number of land rights (three out of 15) in the geographical study area. That notwithstanding, landowner women seem slightly better (as they derive their rights from landowner men having stronger 
rights) than settler women who derive their rights from settler men with far weaker land rights. More insight into this can be found in the discussion section.

Again, Table 4 shows the specific land rights as well as the number in use per category in the study area. From the table, rights with asterisk (*) against them is an indication that the right exists, being used by and benefiting the group concerned. Rights with dash (-) against them is an indication that the concerned group does not benefit from that right even though it exists for other groups. However, where there is an asterisk and a dash (*-) together, it implies a limitation is placed on the existing right for the group concerned. Such a limitation is controlled almost exclusively by landowners. For instance, in Table 4, columns 3, 4, and 5, both women and settler males lack any ownership while landowners exclusively have such ownership as shown in Table 4, column 6 . On the other hand, females' rights to purchase land as expressed in row 13 is limited since they cannot exercise such rights without male consent and involvement. Settler males can purchase that land and all the rights that come with it outright. However, landowners self-evidently lack it completely since they cannot buy what already belongs to them, they explained.

In the bundle (number/group) of land rights identified in the geographical study area, there were 15 in total directly benefiting one group or the other in varying numbers, as shown in Table 4 . Male landowners possess 14 in the bundle containing 15 rights, and only lacking the right to buy their own land as mentioned earlier. Male settlers have nine (i.e. seven clear and two limited) rights out of the 15 contained in the bundle of land rights and have the right to buy land they are currently occupying; which landowners customarily do not have. All females (columns 3 and 4 in Table 4) possess six (three clear and three limited) rights of the 15 contained in the bundle of land rights in the area, which are: use, cultivation and pecuniary (monetary) benefits. Within the customary system, women's right to buy land is generally limited and dependent on male support from husbands or other male relatives. It is important to highlight responses from the focus groups that unmarried daughters and wives have automatic access and use of their fathers' and husbands' lands for farming to sustain themselves. However, this access and use right of daughters ends at marriage and at divorce for wives. At the death of the husband, the interviewees said custom recognises the widows' continuous and almost exclusive right to access and use such land during her remaining lifetime. However, that right ceases if or when she remarries outside the family. Also, daughters' automatic rights to their fathers' land continues forever except if they enter into a marriage in which they derive their land rights from husbands. Sons, however, can inherit all their late fathers' land rights, including ownership, gifting, and sale, depending on whether they are landowners or settlers.

Generally, land rights in the study area include the right to access, hold and use as well as to control a certain unspecified size of the land held for farming or other purposes. The FGDs revealed that farmlands held by married female settlers in the rural areas are typically as small as $0.2 \mathrm{ha}$ (because they are complementary to husbands' farmlands), while the male settlers' farmlands 
averaged two hectares. By implication, widows almost exclusively hold and 'control' larger farmlands of their deceased husbands' than do married women. Meanwhile, rural male landowners still hold up to four hectares of farmland while rural women also from the landowning group hold an average of $0.2 \mathrm{ha}$ under similar conditions to settler women (see Figure 13). In the case of settlers (male and female) in urban areas, there is virtually no legitimate farmland remaining except tiny pieces surrounding houses. All urban settler FGDs said they have to either re-negotiate with developers to squat temporarily or encroach on other people's land to farm for their food supply. The people in all FGDs explained several implications of this situation for their livelihoods that affect food security, peaceful co-existence, emigration, and fear of increasing crime (mentioned earlier) among the youth.

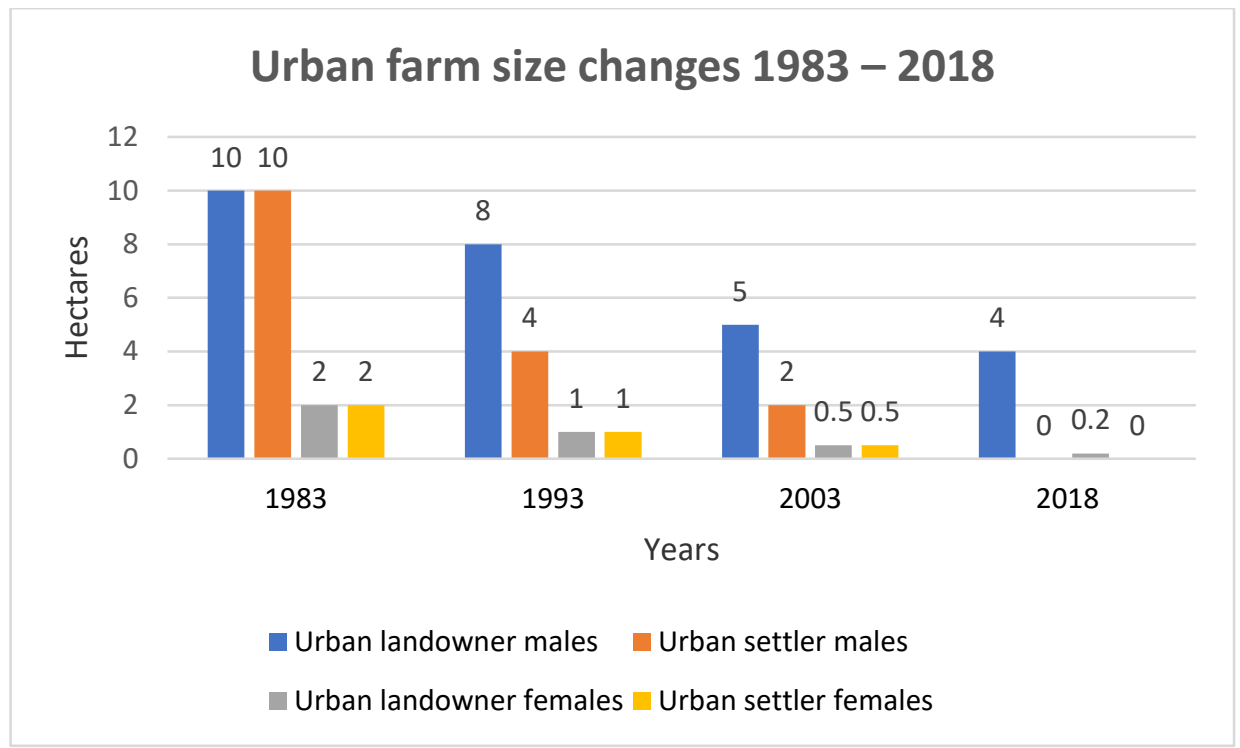

Figure 13 Changing peri urban farm sizes (Almost identical to Figure 7)

Regarding temporal inequalities of farm sizes among farmers, there is a downward trend in farm sizes while population growth follows an upward trend. From Figures 13 and 14, there is a trend in the reduction of farm sizes across all groups over nearly four decades. For instance, in 1983, both landowners and settlers held an average of over 10 ha of farmland, whereas women (i.e., adult/unmarried daughters and wives) only held an average of about two hectares of farmland. One can see from Figures 13 and 14 that male landowners' landholdings reduced by an average of about $60 \%$ to four hectares and that of male settlers reduced by $80 \%$ i.e. to about two hectares on average. For all women, their remaining farm size reduced by $90 \%$ to 0.2 ha compared to two hectares in 1983. This means that land losses by landowner males, settler males and all females are $60 \%, 80 \%$, and $90 \%$ respectively. It is noteworthy that some of the females who lost more lands held smaller farm sizes in the past and are even smaller now. Careful scrutiny of the percentages in relation to absolute farm sizes show that women's (particularly daughters' and sisters') farms remain with an insignificant 0.2 ha on average. Widows' 
farm sizes (i.e., late husband's farmlands) are much the same as other males in terms of size and rights exercised. By implication, mature and independent daughters, sisters, as well as women not in some form of relationship with males have difficulties accessing and/or using customary land in the area as compared to wives and widows. As a result, such women may not be able to independently engage in farming that is sufficient for their food supply and possibly for sale. This is particularly because, as shown in Figure 14, farm sizes for all categories generally reduce as time passes but more so for settlers and this is even more common for women.

Another key finding of this paper is that while both landowners and settlers complain of farm size reduction, vast areas of uncultivated lands were seen dotted across the area. Interviewees indicated that ownership of such land is being contested (so they fear to till such land). On the other hand, the lands may have been repossessed from settlers, sold to developers, or awaiting construction.

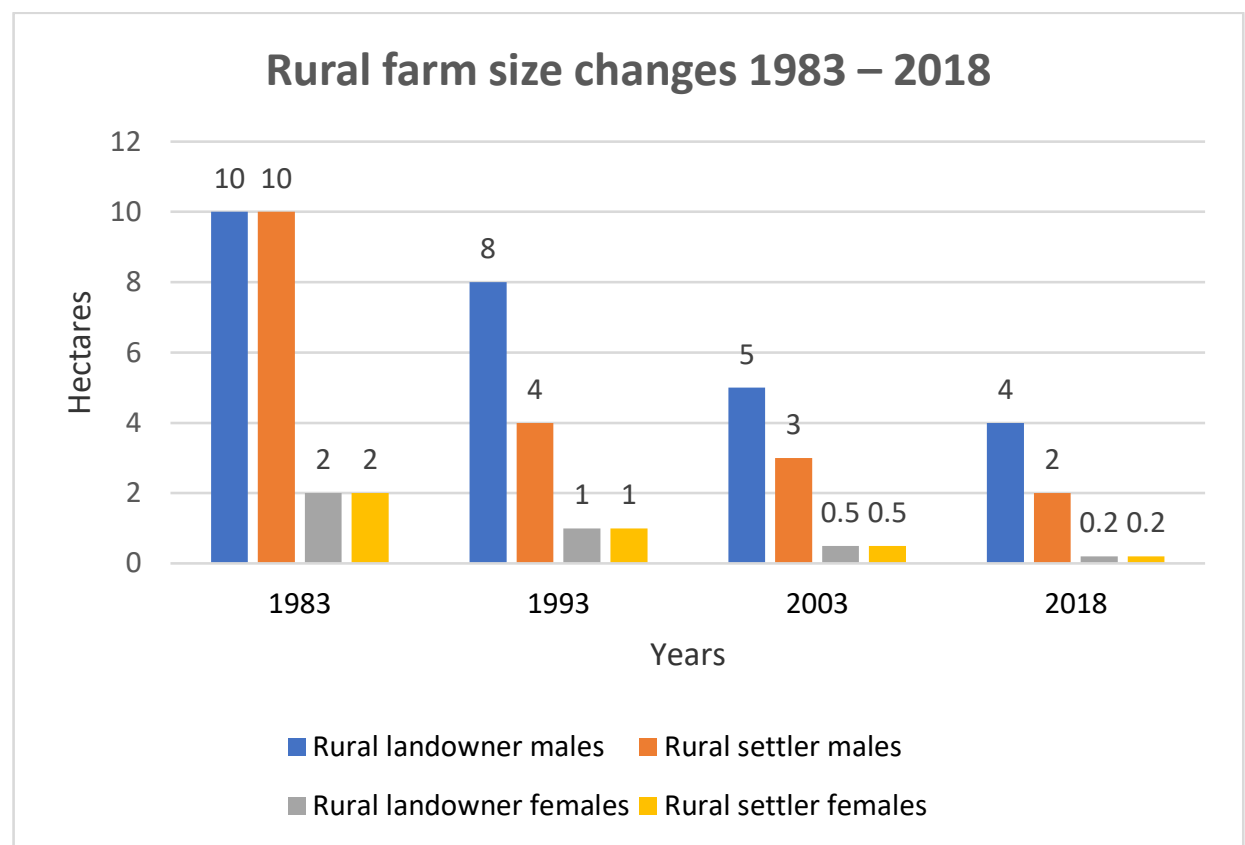

Figure 14 Changing rural farm sizes (Almost identical to Figure 6)

The numerical or statistical information collected during this research was from respondents through the various data collection techniques used. It was not the whole community that provided this information. Rather, various categories of groupings of individuals were selected by communities themselves to represent each community. The research aggregated the statistical data collected from individuals and groups through consensus building and calculated the mean for each category and year. In the main, the presentations therefore accurately represent the numerical expressions from the participants during data collection. It is a fair and accurate representation 
because the research reported back all the information received from respondents to each community in PowerPoint format and the slides were verbally explained at separate community forums. Thus, the communities (who are not exactly the same individuals at each meeting of the same group) had the opportunity to clarify and confirm the data as accurate and representative of their lived experiences as they themselves had freely expressed them. Furthermore, the FGDs discussed matters pertaining to communities rather than to the individuals present at the meetings. Therefore, although individuals were engaged in the discussions, they spoke about their communities' situations and very rarely referred to individual situations to support their assertions. Therefore, the final responses were collective, by following consensus building during every stage of the data collection process.

\subsubsection{Implications for Farming, Food Availability and Food Security}

Other implications of land rights inequalities among smallholder farmers are difficulties in: (1) accessing and securing sufficient farmland to farm, and (2) making food available and ensuring food security. Farmers were asked about what changes (if any) have occurred regarding the crops they cultivated in the past in order to secure food. They responded that some landowners and all settlers have discarded tree (cashew) plantations and long (4-6 months) maturing crops, e.g., local beans, millets, and yams. They have now resorted to fast maturing short season (2-3 months) exotic crops (e.g., soya beans, groundnuts and guinea-corn called "dorado"), especially in the urban areas. By doing this, they aim to reduce the risk of losing crops to developers who sometimes intensify their construction activities a month or two before the rainy season ends to harvest and store water. The FGDs complained that such fast maturing exotic crop varieties require many inputs such as fertilizers, insecticides and weedicides to achieve sufficient yields. The money needed for such chemicals, which farmers claimed they lack, results in insufficient yields, thereby affecting food availability and food security.

On the number of months of food availability from their farming activities, their responses are shown in the graph in Figure 15. This graph shows that there is a steady decline in the quantity of food available that they have harvested from their farms over the years. This is because of the challenges of land rights to access, hold, and use, which affects farm sizes, especially for the settlers and women. Again, FGDs have indicated that their current average farm size of two hectares may sustain them in the short to medium term, but only if they incorporate some technology into their farming activities. Finally, on food security, FGD participants and other interviewees indicated that some coping mechanisms have been adopted by people. Otherwise, their farm produce will likely last for 2-3 months instead of the current 6-8 months of food availability over the year, as shown in Figure 15. The coping strategies were said to include engaging in paid labour, menial jobs and seasonal migration. They are worried that these income sources are uncertain and cannot guarantee their food security into the future.

Respondents were asked to give reasons for these trends in food production and availability. It was mentioned that landowners' food insecurity is largely influenced by their reduced farm sizes, but also by weak finances for investing 
in modern farm inputs to increase their farming outputs. Landowners attributed their farm sizes reductions to sub-divisions among expanding family units. Furthermore, the seemingly large lands of landowners are either under conversion into gravel/sand extraction or stone quarrying. Therefore, those lands have apparently been sold to developers and awaiting the start of construction. Additionally, some lands in the urban areas have been compulsorily acquired but landowners still claim ownership because compensation has not yet been received. As a result, even though landowners across the study communities seem to have large farm sizes and are quite unrestrained in terms of making farming decisions, their average food sufficiency from their farming activities is still surprisingly only eight months. Settlers, on the other hand, attributed their food insecurity mainly to customary land rights inequalities, reducing their farm sizes with a consequent lack of security of tenure and a lack of agricultural inputs. On the other hand, settlers with less land, land rights and farming decision-making options report six months of regular food availability from their farming activities in both rural and urban areas as shown in Figure 15. It is worth noting that the interviewees expressed difficulty in clearly distinguishing between consumption from their own farming activities and coping strategies because they employ the two approaches simultaneously. The respondents have demonstrated through this research that weak land rights lead to uncertain tenure durations and reducing farm sizes, which affects farmed area, farm output, food availability, accessibility and food security.

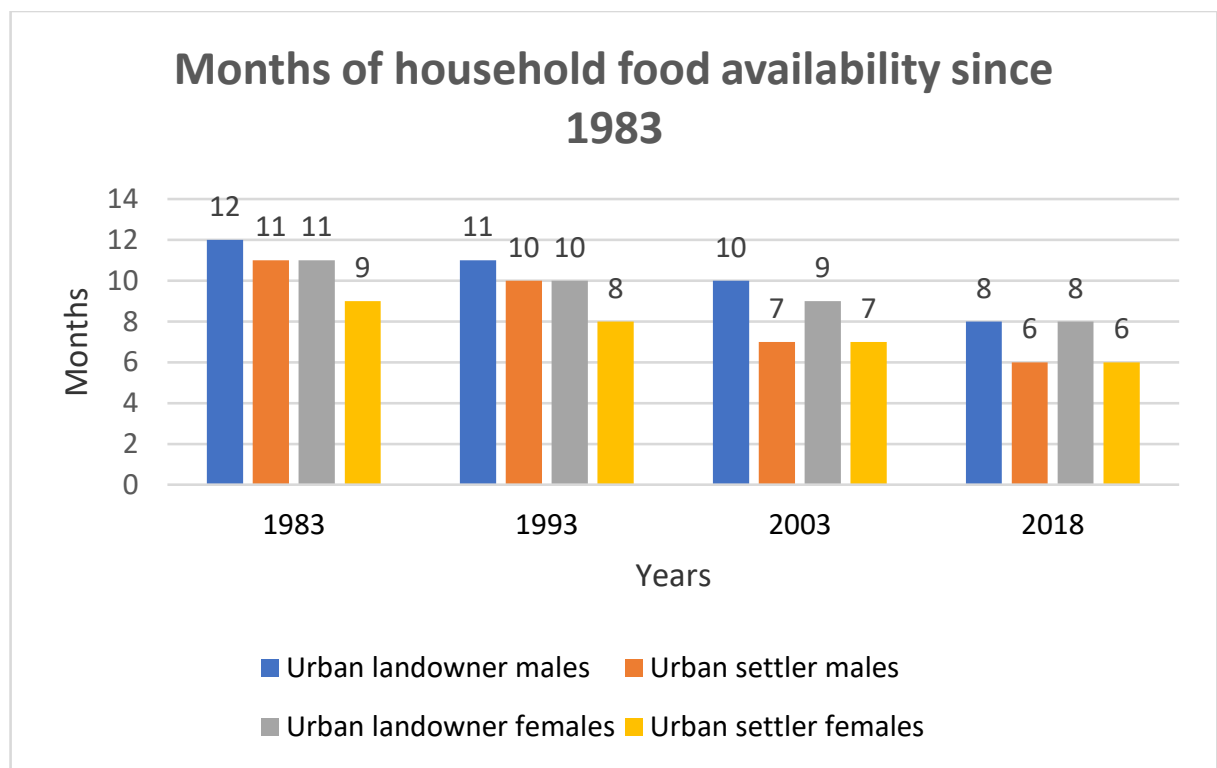

Figure 15 Annual household food availability

There were several observations of various groups' food availability as shown in Figure 15. The first is the gradual decline in the months of food availability (from landowners' farms) from 12 months in 1983 to eight months in 2018. For settler farmers, the trend shows a reduction from almost 12 months to six in the same period. While months of food availability from women's farms 
reduced from about nine to six months over the same period. Both male settlers and all women were asked how they are able to survive beyond six months once food produced from their small farms is exhausted. They claimed that they have adopted some coping strategies. For instance, they purchase food using the proceeds from their rearing of animals (usually free-range), and menial jobs, paid labour, trading and use remittances to supplement their farm produce. Settler farmers in the urban areas also engage in paid labour and use the income to supplement their backyard/kitchen gardening activities. One settler female farmer said the food from her farm might last between one and two months if she did not adopt any coping strategies. Another finding was that settlers in urban areas said they do not have farmlands left. However, it became clear that the lands surrounding their houses are currently being farmed, which still supplies some food. All this notwithstanding, they stressed, if this downward trend continues, other implications than reducing food security may emerge. This can have other impacts on local, national, and global food security efforts and development in general.

\subsubsection{Other Implications}

With reference to some of their lands being compulsorily acquired without compensation or resettlement and, no renegotiations or information on any restitution, one settler farmer in Kunfabiala questioned:

"How can you purport to be establishing a university for people and you are indirectly sacking us and not making any arrangements to resettle or even compensate us? Worst of it, you will not even allow us to squat until actual construction commences. Just because we have no one to speak for us, that is why our age-old land rights are being trampled on and making life for us miserable with nearly no hope for the future of our children. What manner of development is this? Therefore, you see why peaceful co-existence is eluding all of us (landowners and settlers). This also negatively affects our freedom to work on the little farmlands since we fear attacks from even developers thereby affecting both farming activities and food security."

Concerning direct land sales by landowners, another settler farmer lamented that:

"We currently survive by negotiating with land developers who purchased our farms from our landlords to 'squat' and farm on their plots until the lands are needed for development. However, when this fails, we encroach on people's plots knowing that eviction is imminent. How can we possibly be assured of food security under these conditions?"

Under such circumstances, they resort to engaging in piecemeal farming which clearly further reduces smallholders' food production and food security. For instance, interviewees have mentioned tension and threats to peaceful coexistence and further loss of soil fertility through continuous cropping. Clearly, these interfere with their ability to farm more land and work more hours.

Further implications of land rights disparities found included continuous cropping on the little land left for settler farmers and all women. Both landowners and settlers have become more assertive and protective of their land rights with little regard for tenure norms and formal laws, which have the potential for further tenure disagreements. Worsening interpersonal relationships were said to exist between especially the Dagara and Sissala 
tribes in Fielmua and Nimoro respectively who have been litigating land rights in the law courts at the regional capital of Wa for the past five years. This disagreement has led to reduction of people's current farming area, work hours and farm output/harvests. Therefore, the people urged that government should collaborate with the customary authorities to take stricter measures to rectify these land rights inequalities and the resulting tenure insecurity. The FGDs emphasised the need to ensure people's land rights and tenure security, because many of the people in the area do not possess any skills other than farming. One settler remarked during the FGD in Kunfabiala number (1) that: "The land is just not available for us now, so on what can we produce our own food if not on it? Given the current landlessness among us-settlers, our youth and middle-aged people have been pushed out of the community and out of frustration may do "anything" [referring to unlawful means] to provide for their wives and children. Now you talk about buying food from the market, even though there is some food in the market, but our main source of income is the same farming that we can no longer do effectively. So, it is difficult to meet our food needs if our land rights and tenure issues remain unresolved."

Due to these negative experiences, some interviewees indicated that the situation has compelled them to find other income-generating activities. These new income sources such as paid labour, menial jobs, and learning various trades, including trading (which FGDs complained to be uncertain), are used to pay for food to supplement their traditional food source of farming. This is much more common among urban dwellers than rural people whose alternative is the rearing of animals on a free-range basis.

Another important finding is that even though youth and disabled groups participated in the FGDs, their status seems not to be influenced by land rights and consequent food security in the study area. Rather, land rights and food security implications of youth and disabled in the area are determined by whether they are settlers, landowners, males, or females, but not their youth or disabled status.

\subsection{Discussions}

Land rights inequalities exist in customary areas in sub-Saharan Africa. They adversely affect the tenure security of those who hold weaker rights and negatively influence their food security. This is because such people's food needs and indeed livelihoods are largely dependent on land. This paper has investigated the implications of customary land rights inequalities. It also examined land tenure insecurity among smallholder farmers in northwest Ghana in terms of their nature, number and type. It has also examined how these rights affect people's farm sizes and subsequently farming output to achieve ultimate food security.

It is worth reiterating that there are various categories of rights contained in a bundle of land rights (Christine et al., 2015; Williamson, Enemark, Wallace, \& Rajabifard, 2010). Some people have fewer and weaker rights whose holders experience insecure tenure. Others have more rights in the bundle, which are stronger, leading to more security of tenure. Meanwhile, both weak and strong 
rights influence farming and food security in the area. However, it was unexpected that even landowner women in the study area have considerably weaker land rights than settler men. It is also important to point out that women from the landowner group and settler women appear to have the same weak rights. However, a careful examination of the data shows that their circumstances do differ slightly and are better for landowner women. This is because landowner women rely on landowner men with strong land rights, while settler women rely on settler men with weak land rights. There are both food security and other implications emanating from the above revelations that require urgent attention as discussed further below.

\subsubsection{Nature of Land Rights Inequalities}

Generally, the distribution of land rights varies per category of people and correlates with the level of each group's food security in terms of number of months in the year of food available to them from their own farms.

Land rights and tenure inequality with various dimensions of economic development are already known (Azadi \& Vanhaute, 2019). The implications of land-related inequality constitute a central component of wider inequality and represent a burning issue for our society today (Ameyaw, Dachaga, Chigbu, De Vries, \& Abedi, 2018; Chigbu, Paradza, \& Dachaga, 2019; Wegerif \& Guerena, 2020). Landowners in the geographical study area admitted to the existence of land rights inequalities. These inequalities are skewed against particular categories of people, whether they come from the landowner or settler groups. However, they attribute the reduction of landowners' farm sizes to, for instance, sub-divisions among growing numbers of family members but that effect does not necessarily weaken their other land rights (AEC, 2004). This supports the inverse relationship between population growth and resource availability analysis propounded by Robert Malthus (Quamrul \& Oded, 2008). For instance, looking at the population growth trend in Ghana over recent decades, the population increased by nearly three times from 12.3 million in 1984 to an estimated 30 million in 2019 (Republic of Ghana, 2012). Other reports GSS, (2012); Republic of Ghana (2014) reveal that Ghana's urbanisation rate is slower in the rural areas, with the study region (Upper West) being the least urbanised. From this, it is evident that the reduction of landowners' landholding (by over half from about 10 to about four hectares) is roughly inversely correlated with the trend of population increase. However, the trend of settlers' land reductions by five times less (from about 10 to about two hectares) is much steeper than the population growth over the period. This implies that, in addition to influences of population growth and urbanisation Cotula \& Neves (2007); Dembitzer (2014), other factors must be contributing to these inequalities among the people. Thus, reflecting reduced farm sizes of settlers and women, weak land rights and consequent tenure insecurity in the area. Responding to this, the settler interviewees attributed the widening land rights inequalities and their weakened tenure security to landowners' "growing greed". This greed, settlers contended, is in landowners' anticipation of rising land values due to increasing land commercialisation. In addition, it is the weak enforcement of existing land laws and the absence of specific land rights laws to protect the vulnerable. Meanwhile, landowners attribute the changing land rights of settlers to "inevitable" changing trends, referring to urbanisation, 
population growth, and development in general. For these reasons, landowners claim they have to vary land rights (contrary to custom), in response to these changing circumstances whether they are economic, social or political. This confirms similar findings in Tamale in the northern region of Ghana Naab et al., (2013) which reported similar reasons for changing land rights.

Farm sizes are reported to be decreasing in both Africa and Asia. This decreasing trend will continue in the face of evidence that smallholder farms generally depend on less than two hectares of land for survival (Fanzo, 2017). The size of land holding is falling in the developing world with the fastest decline in Africa (Conway, 2011; Wegerif \& Guerena, 2020). A third of the world's population depends on smallholdings for their livelihoods and food supply even though the average farm size in Asia and Africa is estimated to be just 1.5ha (Conway, 2011; Morton, 2007). There is cause for concern as population increase continues to lead to divided landholdings such that smallholder farms are becoming both more numerous and smaller. However, these smallholder farms remain of great importance to food production and availability, and rural development more generally in developing countries (Conway, 2011; Zant, 2005). There is however, an expectation that, as agriculture develops, it can lead to greater yields. And as production of smallholder and cash crops is sustained, smallholders can gradually become more prosperous (Conway, 2011). This implies there is still hope to improve smallholder farming and food availability. This will assure food security through design of suitable strategies (including technological strategies) and models to mitigate the widening land rights inequalities and the reducing smallholder farm sizes in the future.

\subsubsection{Implications for Food Production, Food Availability and Food Security}

The implications of land rights inequalities among various categories vary based on the distribution of the rights themselves in the first place. It is argued by Morton (2007); Mullan, Grosjean, \& Kontoleon (2011) that land rights inequalities must be viewed contextually (i.e., specific to particular regions). That is why it is asserted in Arko-Adjei et al., (2009); Mullan et al., (2011) that customary institutions should maintain their traditional power to allocate land and resolve land rights conflicts, including rights inequalities. The implications of these inequalities affect several connected aspects of human life at various levels such as social justice, equality and the rule of law. For example, the interviewees reported that unfair land rights inequalities and consequent tenure insecurity is contributing to food insecurity among their families. This can have other unexpected implications as some of the youth and middle-aged people currently engage in seasonal migration to urban areas to earn money to supplement the inadequate food from their farms. However, the research participants expressed the worry that some of their young and middle-aged peers who migrate sometimes do not return to the communities. They end up abandoning their families (usually elderly people, women and children) in the rural areas with insufficient food supplies.

This research found that some aspects of customary land rights (including tenure) have changed to reflect the dynamic humankind-to-land relationship (Arko-adjei et al., 2009). These are: a change (1) of social value of land to 
economic value, (2) from communal rights in land to individual rights, and (3) of land use patterns in general. Note that customary tenure arrangements cover more than $80 \%$ of land and associated rights in Ghana, as stated earlier. Therefore, Ghana's land rights issues will require a thorough analysis of possible imminent unintended negative implications for food security, among other factors. Furthermore, population growth and the changing economic importance of land may have partly influenced changes in land rights and crop farming, and as a result have food security implications. This is because, the FGD participants admit that the challenge of land rights inequalities and consequent tenure insecurity have directly affected farm sizes, farming investments, yields, and food security. This is seen in terms of less food availability from their farms as captured in literature (Lawry et al., 2014; Nguyen, Tran, Bui, Man, \& Walter, 2016; Riesgo et al., 2016; Ruerd \& Policy and Operations Evaluation Department (IOB) Ministry of Foreign Affairs, 2011). Therefore, the nature of land rights inequalities and implicit tenure insecurity in the study area have negative consequences for both farming and food availability (Duncan \& Brants, 2004; International Fund for Agricultural Development, 2015).

Land rights are least secure for women (who are not household heads), whether they are part of settlers or landowners. It implies that the associated implications for food availability also weigh heavily on women (International Fund for Agricultural Development, 2015). For instance, women's land rights depend on access through their male relations and so they cannot independently enforce their rights or make major farming decisions to (for example), increase their farm yield. Therefore, even as formal land laws in Ghana are non-discriminatory, they are still inadequate or poorly implemented such that some customary practices in the study area still obstruct women's land rights (Duncan \& Brants, 2004). However, widows who remain unmarried and live in their late husbands' houses do have some perpetual rights to use their late husbands' lands. These rights are stronger if there are children involved, especially males. Having sons was again said to secure widows' land use rights, tenure security and, consequently, food security but not land ownership in any manner. Nevertheless, such rights of the widow cease if she remarries outside of the late husband's family. Interestingly, women were asked which of their children (male or female), they would prefer to inherit the mother's land. The women were unanimous in declaring the preference that their sons rather than their daughters should inherit mothers' land. Their reasons are much the same as those that men usually give for few and weak female land rights in the area. Both women and men contended that women in patrilineal societies do not "have permanent homes to" inherit such rights. Interviewees also mentioned external factors such as immigration and urbanisation as directly contributing to land rights and tenure changes especially in the urban areas (Akrofi, Whittal, 2013; Dembitzer, 2014). Additionally, interviewees mentioned general economic transformations that influence and accelerate the already existing internal customary mechanisms for changing land rights. This again confirms similar findings from Tamale in the northern region of Ghana (referred to earlier) (Naab et al., 2013). 
The implications of land rights inequalities and customary tenure insecurity found in this research has also been corroborated (Boudreaux \& Sacks, 2009; Kidido et al., 2017; Kyeyune \& Turner, 2016; Savenije et al., 2017). These authors suggested that weak land rights and insecure tenure lead to reduced crop yields in small farms with consequences for food security. This finding strengthens the call for stronger land rights and tenure protection through public policy and social safety nets to enable smallholder farmers meet their daily food needs through farming (Wehrmann, 2008, 2017). To further support Gollin's assertion, farmers (especially landowners) have downplayed customary land rights issues and instead complained of non-tenurial (soil infertility and their financial inability to use modern farming strategies) that affect their ability to improve yields. As a result, landowners resort to taking back their lands from others, thereby reducing the farm sizes of settlers and women in particular in the process. This is also supported by Bugri's finding that, in the Upper east region of Ghana, food insecurity emanating from low crop yields among landowners was largely attributable to non-tenurial factors such as soil fertility, water availability, farming inputs and financing (Bugri, 2008). Therefore, the injection of significant farming inputs to increase crop production seems positive for vulnerable categories of smallholder farmers in addition to mitigating land rights and tenure issues. However, it must be borne in mind that settlers and women instead, emphasised that land rights, access, and consequent tenure security are more important to increasing their food production as corroborated in the literature (Kyeyune \& Turner, 2016; Ruerd \& Policy and Operations Evaluation Department (IOB) Ministry of Foreign Affairs, 2011).

Generally, agricultural productivity in the study area is already regarded as poor, as reported in the Ghana Living Standards Survey Round 6 (GLSS 6) (Amuzu et al., 2014). This is claimed to be due to poor soil fertility, poor rainfall patterns, continuous cropping on the same parcels. The continuous cropping and poor agricultural productivity in the study area implies land scarcity coupled with little mechanisation. Therefore, adding land rights inequalities and tenure insecurity to the above, suggests that the challenges faced by the people are more numerous and bigger than anticipated. Settler and women interviewees attributed their continuous cropping practice to reducing farms that tend to deplete soil nutrients quickly. This explains why settlers and women achieve lower yields and food availability as compared to landowners who have large farmlands.

\subsubsection{Indirect Implications}

Beyond food insecurity, reports suggest weak adherence to, and poor enforcement of land laws in Ghana's courts, which is evident in the high number of unresolved cases (Wehrmann, 2008, 2017). The slow rate of resolving land cases in Ghana's courts contributes to growing disregard for people's land rights especially under customary arrangements. Gyamera's work on justice delivery in the courts in Ghana reported that "land cases pending in Ghana's courts constitute about 59\% of all court cases" (Gyamera, 2018). The delays in the courts have contributed to festering tenure disagreements and widespread tenure insecurity found in the study area. The people mentioned their dislike for the imminent threat to peaceful co-existence 
and a sense of suspicion among the otherwise peaceful inhabitants. There is bound to be some undesirable implications (they stressed) for food security and general social wellbeing when different farmer groups believe their competing interests are incompatible as wide inequalities of land rights and other entitlements persist (Sietchiping et al., 2012).

\subsubsection{Conclusion and Recommendations}

This research does not purport to conclude that the implications of land rights inequalities center only on food security. It aimed to identify the nature of land rights inequalities among smallholder farmers and the accompanying implications, both direct and indirect. The second was to examine the implications of land rights over time. Thirdly, it aimed to analyse the implications of land rights inequalities for food production, availability and subsequent possible food security. This is also key because smallholder farming remains a main source of income and food supply to many households, especially in sub-Saharan Africa (Lipton \& Saghai, 2017).

The results have shown there is weakening reliance by the people on legal processes because there is little strict enforcement. Paradoxically, the same people expressed their trust in the potential effectiveness of the legal system to finalise sensitive cases that customary systems cannot resolve. Notwithstanding the long delays, Wehrmann (2008) in addressing land cases in the courts in Ghana (mentioned earlier), if land cases in the courts would be more speedily resolved, the legal system could facilitate processes to strengthen land rights and secure tenure. The results also showed that various categories of people (e.g., secondary land rights holders, namely women and settlers) experience varying levels of vulnerability to land rights inequalities. It is evident from the results that funding is important to promoting farming and securing food in general. Equally evident from the results is that strong land rights and secure tenure remain fundamental to improve food security of marginalised secondary land rights holders (i.e., women and settler farmers) (Bugri, 2008). In spite of the general vulnerability and marginalisation of women regarding customary land rights and tenure security, this research has revealed that wives and especially widows in the study area (patrilineal setting) have stronger rights and more secure tenure than other women (daughters and sisters). There are indirect but critical effects caused by emigration, suspicions and tensions affecting peaceful co-existence that further impact on food security in the area. Further research is therefore necessary for a collaborative effort to better understand land rights inequalities and their implications, and to contribute to informing interventions to narrow these inequalities in order to contribute to improving food security.

What has become evident from this research is that those with the weakest land rights lost the most land. These land losses are visible in Figures 13 and 14. The land losses have significant implications for their survival in the future and demonstrates the need to increase the land rights of those with weak rights to create a more equitable land rights environment for everyone. It is anticipated that this would have positive impacts on their ability to hold onto land and maintain food security, in the medium to long term. It is pertinent to state that not addressing this situation will have dire consequences for those 
with weak land rights over the coming years. At least, it is clear by now that those with weaker land rights are more impacted by the allocation of land to developers and other investors in the study area. It is with these new pressures on land that the weaker land rights are exposed as being a serious problem that results in greater food insecurity at the household level. This food insecurity can affect national and international food security if care is not taken to prevent it from becoming more widespread. However, smallholder farming has been acknowledged in the literature discussed earlier to contribute at least $60 \%$ of the food needed to feed the world. Therefore, the undesirable land rights inequalities and the inevitable increasing pressures on land call for greater efforts to strengthen land rights for those with weaker rights, and to create more equitable and stronger land rights for all. 


\section{Chapter 4 Influences of community land rights and tenure security intervention processes on food security in northwest Ghana}

This chapter is based on a contribution in a book chapter - Responsible and Smart Land Management Interventions - An African Context. by Francis and Taylor Group titled: Influences of Community Land Rights and Tenure Security Intervention Processes on Food Security in Northwest Ghana Baslyd B. Nara, Monica Lengoiboni, and J.A. Zevenbergen 


\subsection{Introduction}

A joint FAO, IFAD, UNICEF and WFP, (2018) report claims that globally, many people lack land and related rights to produce food for themselves. They may therefore lack agricultural revenue for food accessibility too, and thus worsening food insecurity (FAO, 2019). For instance, WFP says "on any given day, it has 5,000 trucks, 20 ships and 70 planes delivering food to those in most need," yet global food insecurity still persists and affects one in nine people (FAO, et al., 2018). Fertile agricultural land is a major source of livelihood for many people in Asia and Africa but scarce, thereby threatening food production (Duncan \& Brants, 2004; Lawry et al., 2014; Ruerd \& Policy and Operations Evaluation Department (IOB) Ministry of Foreign Affairs, 2011). This is partly due to demographic growth changing customary laws and practices where state legislations and implementation are either weak or absent or, where there is low farming input (Bugri, 2008; Naab et al., 2013). Little attention is paid to smallholder subsistence farming even though such farms generate majority of food consumed in the world (Lawry et al., 2014; Mwesigye, Matsumoto, \& Otsuka, 2017). Also, little research covers 'unnoticed' tenure insecure groups like settlers (i.e. permanently resident migrants) in customary areas in Ghana who possess less secure secondary land rights which tend to hinder their farming. This research seeks to suggest responsible land management interventions from local practices to first secure land rights and tenure in order to enhance subsistence farming for food security in line with (de Vries and Chigbu, 2017; Zevenbergen; de Vries and Bennet, 2016, p.6-7). Land management is responsible if it is resilient, robust, reliable, respected, reflexive, retraceable and recognisable (de Vries and Chigbu, 2017). Such interventions are important as settlers in some communities in Ghana constitute up to $80 \%$ as compared to $30 \%$ in Ivory Coast (Cotula, Toulmin, \& Hesse, 2004). In both countries, farmers often suffer land rights and tenure challenges such as evictions, rights variations, reduced farm sizes etc. which are consequential to food security (Cotula \& Toulmin, 2004; Lawry et al., 2014).

Food security is when "all people, at all times, have physical, social and economic access to sufficient, safe and nutritious food that meets their dietary needs and food preferences for an active and healthy life" (Pinstrup-Andersen, 2009). This chapter first focuses on food availability component from their own farming, upon which access, nutrition and stability dimensions revolve. Land rights and tenure security, often based on customary tenure and service arrangements, remain a major means to food supply and income of most people in sub-Saharan Africa (Lawry et al., 2014; Ruerd, 2011; Simbizi, 2016). These service arrangements are basically non-monetary tributes which landholders are required to seasonally render to landowners to acknowledge landowners' ownership rights and renew landholders' access, holding, use and 
other rights. Therefore, when these arrangements hinder farming, agricultural revenue is reduced thereby affecting farmers' food accessibility since subsistence farmers sometimes sell some of their produce to buy foods they lack.

Since customary tenure is socio-culturally unique, responsible land management interventions require addressing contextual user requirements to secure land rights. This however may necessitate formal state facilitation to locally re-negotiate and alter service arrangements to be compatible with changing trends.

\subsubsection{Land tenure security, challenges and mechanisms to address them}

A landowner in northwest Ghana is tendana in Kunfabiala and Sing, tortina in Nimoro and Piina 1 or tengansob in Fielmua and Piina 2. He controls family/clan lands by ensuring that rights of both members and non-members are secure based on custom and within the formal legal framework. Land tenure security involves the protection that landholders have against involuntary removal from the land they hold (Almeida \& Wassel, 2016; Boudreaux \& Sacks, 2009; Simbizi, 2016). It is the perception that tenure is secure and influences land use or farming decisions (Bugri, 2008; Simbizi, 2016). Secure and large land are a precondition for 'profitable' farming for most people in sub-Saharan Africa (Payne, 2004; Ruerd \& Policy and Operations Evaluation Department (IOB) Ministry of Foreign Affairs, 2011). Customary tenure and service arrangements can provide adequate security because land rights once allocated, are rarely revoked under customary law and practices (Kasanga \& Kotey, 2001; Place, 2009; Platteau, 1996). The rare circumstances for revocation are absence of heir, gross misbehaviour (denying landowner's ownership) and abandoning the land.

A complexity of tenure systems exists in most developing countries, so its degree of security and influence on livelihoods is crucial (Chauveau, et al., 2007). Tenure security in the form of formal legal, customary or religious land rights, can provide some predictability and access to fundamental rights, including to food and housing (Wickeri, 2010). Cotula \& Toulmin (2004) suggest that the state can legitimise land rights by validating (documenting) local practices. But Zevenbergen et al. (2013) caution that registration alone does not secure tenure. De Soto equates land tenure security to recognition of existing rights by means of formalising (Brasselle et al , 2002). However, Lawry et al. (2014) question the impact of formalising customary land rights on investments, especially in sub-Saharan Africa. Cotula \& Mathieu (2008) find that in four sub-Saharan African countries, neither titled tenure nor land transfer rights affected farm productivity. Also, Almeida \& Wassel, (2016) find that the current land law in Timor-Leste does not provide legal rights for those without any documentation, yet most of the respondents without 
documentation still consider their tenure as secure. That is why for Lund, (2000), land tenure security exists when an individual perceives that $s /$ he has land rights on continuous basis, free from imposition or interference from outside sources and the ability to reap the benefits of investments in it, either in use or upon transfer. Bugri finds that $80 \%$ of his sample farmers in neighbouring north-eastern Ghana, with no registered title felt that their land rights and tenure were secure. Also Obeng-Odoom (2012) clarifies, it is the perception of secure tenure that matters, not necessarily a formal legal mechanism.

Customary land law is noted to historically offer the best security of tenure to individuals, families and local communities (Akrofi \& Whittal, 2011). But levels of tenure security differ on gender grounds (Duncan \& Brants, 2004). Yet, tenure remaining relatively secure for different categories of people irrespective of age, disability and status, is still challenging. On the whole, secure land tenure whether legal, de facto or perceived, is the recognition of one's bundle of rights for a given period which is long enough to support investment and recouping the benefits (Lambrecht \& Asare, 2016; Nguyen, 2014; Van Gelder \& Luciano, 2015). For Boudreaux \& Sacks, (2009) forcible eviction and deprivation of land rights, places responsibility on formal authorities and customary custodians. Therefore, a critical investigation is worthwhile to ascertain local interventions to strengthen land rights and secure tenure. It is also important to ascertain how adequate these local procedures are, in addressing land rights and tenure security for farming and food security.

\subsection{Methods}

This explorative study was conducted from June-December, 2018. This duration witnessed the commencement of farming activities through to harvesting, facilitating assessment of how changing customary tenure and service arrangements affect land rights and influence farming. Direct narrations of respondents' personal experiences on avenues used in resolving their tenure challenges (in Figure 16 below) were obtained, analysed, presented and discussed. Key issues they responded to included tenure security and farming, stakeholders' role in securing land rights as well as community perception, challenges and indicators of food security.

The research used focus group discussions (FGDs), key informant interviews, institutional interviews and satellite image interpretation. Focus groups ranged between 8 and 12 people (Hancock et al., 2009; Kothari et al., 2014). Separate FGDs of male and female elders, aged 60+ and youth aged between 18 and 59 (Republic of Ghana, 2012), were conducted. The disabled FGDs were categorised into males and females irrespective of age. A total of thirty-six FGDs were conducted in six communities involving about 400 individuals. Additionally, six key informant interviews were conducted with three each of 
indigenous landowners and heads of settler groups. Two institutional interviews were conducted with regional Lands Commission (LC) and Wa Central Customary Lands Secretariat (WCCLS). The categorisation of the focus groups facilitated collection of data specific to each group. It became clear that age and disability do not influence land rights and tenure in the communities, but rather status (landowners or settlers) and gender. This guided the rest of the analysis.

\subsubsection{Data analysis}

The data comprised of audio recordings, hand-written proceedings of FGDs, interviews and satellite images. The results have been presented in maps, graphs and charts. The emerging issues were juxtaposed with literature in descriptions and discussions, based on which an informed opinion is expressed in conclusion and recommendations.

\subsubsection{Study area}

The study area is Upper West region (also referred to as northwest) of Ghana, where the nature of customary land rights and tenure system (explained later) may have attracted people from Ghana and Burkina Faso as settlers since time immemorial. The communities together cover a total land area of 3,641.74 $\mathrm{km} 2$. They were purposively selected due to prevalent dominance of subsistence and settler farming (Republic of Ghana, 2012). Also, its land tenure system is unique in Ghana, i.e. initially without land sale or sharecropping. There are intermittent subtle and sometimes escalated land rights disagreements between landowners and settlers affecting farming and food security. Additionally, there is reported out-migration of youth claiming they can no longer secure food from their own farming activities, due to weakening land rights and increasing tenure insecurity.

The communities visited included Kunfabiala and Sing in Wa Municipality with approximately $234.74 \mathrm{~km} 2$ of landmass and the most urbanised place in the region. The other two largely rural districts are Lambusie-Karni and Sissala West, having $(1,356.6 \mathrm{~km} 2)$ and $(2,050.4 \mathrm{~km} 2)$ of land area respectively. They are located over $200 \mathrm{~km}$ north, sharing boundary with each other and southern Burkina Faso. The choice of rural and urban areas was to determine the extent to which their urbanity or rurality affect land rights and tenure security, and influencing farming and food security.

\subsection{Results}

\subsubsection{Local processes of resolving land rights and tenure challenges}

The regular 'payment' by settlers of the 'token gift' called kagyin or kaju to landlords in accordance with custom was indicated by landowners as settlers' duty. Meanwhile, settlers admitted their failure to meet this obligation due to 
smaller infertile lands and continuously poor harvests which settlers claim is obvious to landowners. Settlers in Fielmua claim that for them, 'token-giftgiving' tenure service ended centuries ago, marking their assumption of landowner status to which their original landowners in Nimoro are contesting in court. All the FGDs indicated that such disagreements weaken rights as landlords are currently selling lands that settlers claim to have become infertile, and reclaiming lands that settlers hold without rendering the required customary services. In addition to the above and to offer interventions in land rights and tenure challenges, other avenues exist. These are specific local 'offices', institutions and organisations who are direct or indirect stakeholders in customary land rights and tenure security in northwest Ghana. From Figure 16 below, a landholder having issues goes to group head to mediate. If it fails, it goes to tendana involving CLS for spiritual or administrative intervention. When that fails, it goes to the chief to arbitrate and also moves to Lands Commission for notification (verification) and if that fails too, then it goes to court for final adjudication.

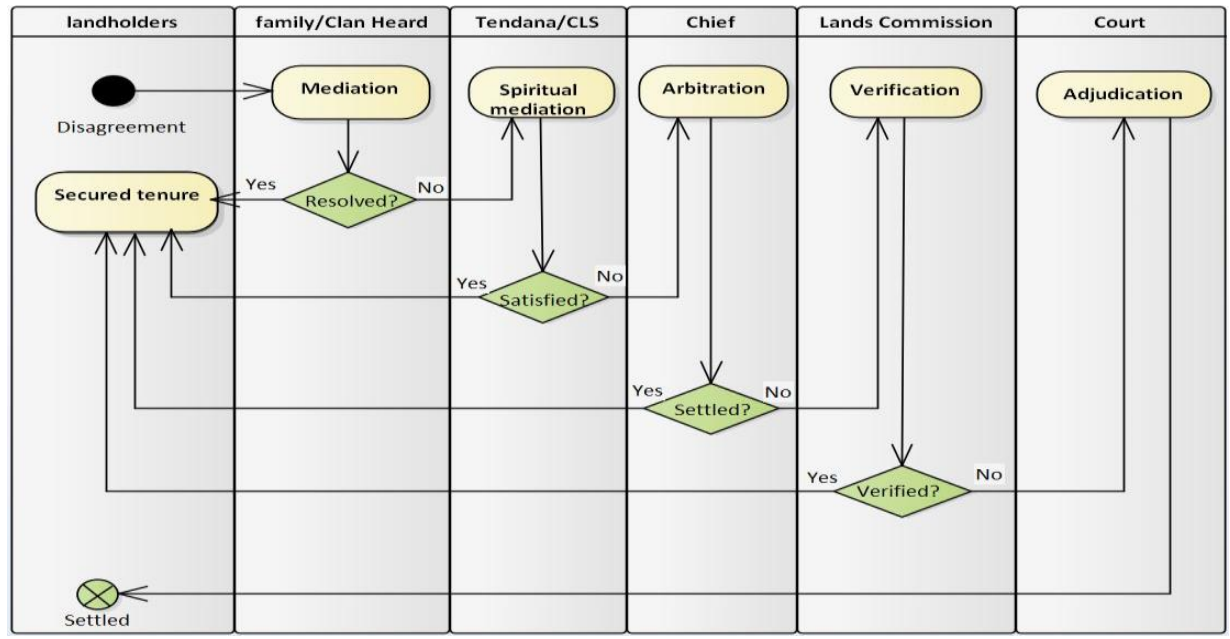

Figure 16 Local procedure for settling customary tenure challenges. (Author's construct 2019, using Enterprise Architect).

The people reminisced the peace that accompanied farming, food availability and food security when this order was strictly respected. The FGDs indicated that seeming non-adherence to the procedure in Figure 16 above, is because there are virtually no punitive measures meted out for non-compliance. A land management intervention that is responsible based on user requirements to secure land rights and tenure is desired by communities, to curb the growing disregard for people's rights and foster inclusiveness. FGD participants mentioned that stipulated re-negotiation and subsequent documentation can curtail both landowners' and especially settlers' weak land rights. FGD participants also complained that the laid down structure to secure land rights 
in Figure 16 above, would be effective with strict legal backing and penalties for offenders in the constantly changing socio-economic environment.

FGD participants further stated that land rights and tenure insecurity stem from subtle unilateral re-allocation of settler lands for sand, stone and gravel winning rendering the land uncultivable and facilitating its conversion to nonagricultural uses. Consequently, resistance from settlers then worsens the situation affecting farming and food availability with lingering mistrust and fear of possible attacks. In the FGDs, it came out that to resolve the current tenure insecurity calls for renegotiation of customary terms involving all stakeholders with state/outsider facilitation and state endorsement as a measure of responsible land management in line with the community's continuum of land rights. Also, the FGDs indicated that special tenure packages for specific groups, agreed upon and applicable in each area is feasible to minimise frequent and often contested land rights changes/challenges. Settler FGDs specifically proposed that landowners allow settlers to permanently own land not exceeding 2 hectares. Otherwise, these settlers cannot envisage any end to their tenure challenges, suspicions and consequent food insecurity in the following intervention measure:

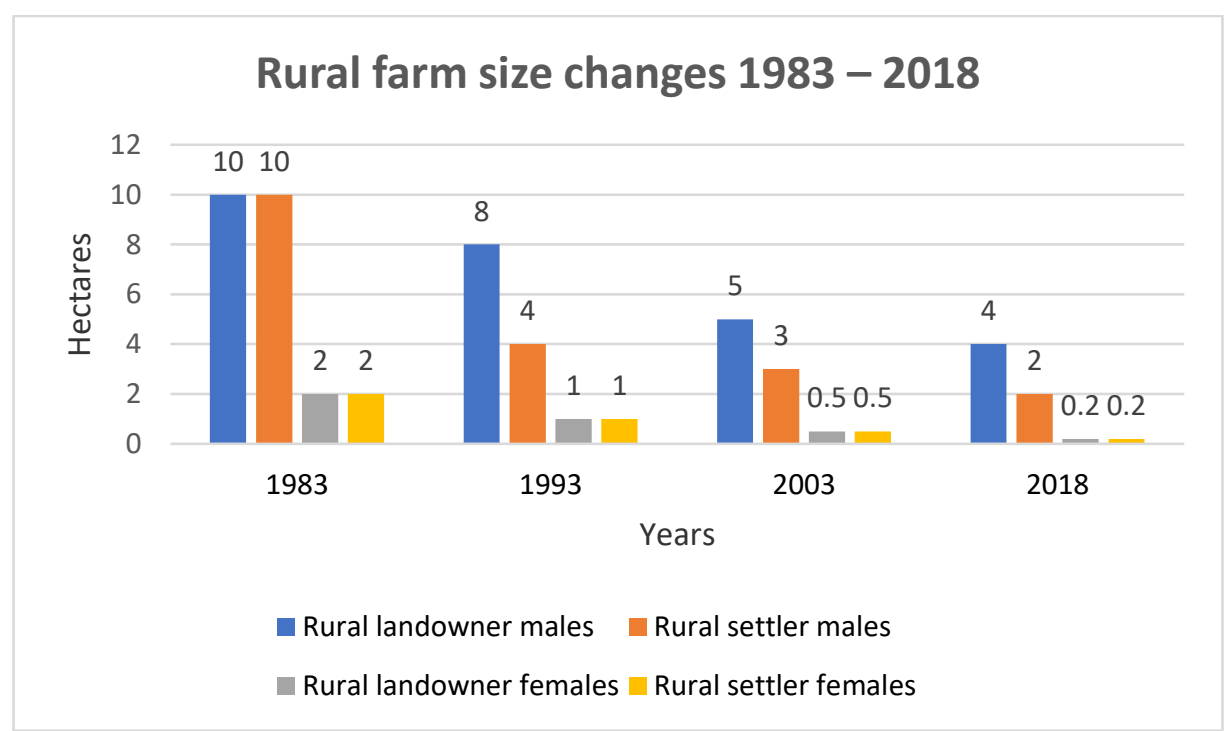

Figure 17 Trend of rural farm size variations. (Almost identical to Figure 6 \& 14)

"we appeal to be spared some minimum farmland of about 2 hectares as our reward for 'protecting the land for landowners' against encroachers, other claimants and potential attacks over the centuries. We have never let them down and they will also not let us down at this crucial moment in spite of current monetary motivations for land sale. This can be an effective land rights 
and tenure security intervention to enable us continue to farm for our food needs. Otherwise, the thought of complete future landlessness rather emboldens us to resist tenure changes being introduced by landowners but this worsens tenure insecurity and consequently affects food security."

The settlers hinted that such purely customary agreements should then be documented by the Lands Commission to prevent any unilateral variations to tenure in the future, as they are currently witnessing reducing farmlands. The case of women is different because women's access and control of land remains almost entirely dependent on their relationship as daughters or wives with men. It emerged from the FGDs that wives farm mainly 'for-soup' crops like vegetables and groundnuts on smaller farms to complement husbands' or household harvests. Figures $17 \& 18$ clearly show the almost insignificantly small farm sizes of females in the study area.

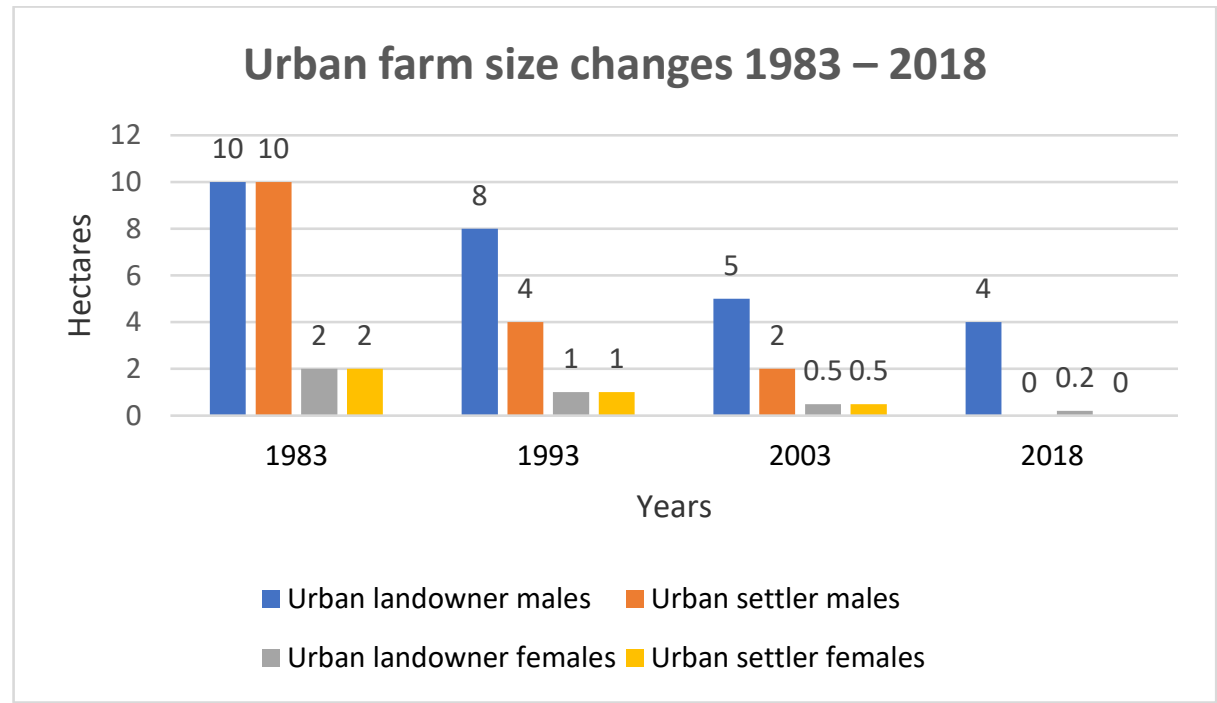

Figure 18 Trend of urban farm size variations. (Nearly identical to Figures 7 \& 13)

\subsubsection{Minimising the challenges of changing customary tenure security}

Land rights insecurity FGD participants said, affects the kinds of production decisions they can make which affects farm output and consequently food availability and accessibility too. Another challenge of the current nature of changing customary tenure and service arrangements is settlers' uncertainty of the extent and time the changes take place. For instance, settlers said currently, landlords unilaterally decide what expanse of land to repossess from them (and for how long), contrary to laid-down customary norms and practices. Even though settlers customarily have perpetual duration on land rights and tenure, the unilateral decision of landowners to re-enter at any time 
defeats that right. This, settlers believe can be minimised with state/outsider intervention. Also, the absence of settler rights to trees in Piina for instance was discussed in the focus groups. Settlers said, partly weakens their farming decision making because it is near impossible for settlers to plant trees as an investment to help re-fertilise farms. These together leave settlers with 'nothing to live for' because they claim some do not know their roots, and so are referred to as settlers but not visitors.

Settlers said they quietly but strongly resisted attempts to dispossess them of the lands they occupy. So, when those in Kunfabiala for instance, heard of eviction intentions, they responded by making more permanent structures to secure their settlements at least. Due to the commercial forces driving land rights changes according to Chauveau et al., (2007), many landlords do not feel obliged to respect the customary norms guiding tenure and service arrangements. To minimise tenure insecurity, the enactment and enforcement of a well-publicised legal framework rooted in customarily re-negotiated land rights was constantly re-echoed by especially settlers and women. The reason they advocate this intervention measure is because, settlers claim 'the ancestors are dead', an indication of loss of trust in the 'spiritual verdict' regarding disagreements on tenure. This 'death' makes landowners abuse land rights of marginalised groups without caution. All FGD participants explained that in times past, major contrary tenure decisions automatically attracted 'invitation to the ancestry' i.e. death. This deterred people from engaging in arbitrariness on land, but urbanisation and foreign religions have partly contributed to land rights changes and consequent tenure insecurity. FGD participants pointed out that rights and land tenure can further be made secure by government-led facilitation to protect the vulnerable. They suggested that government should 1) make or streamline laws, 2) ensure strict law enforcement, 3) promote affordable and socio-culturally acceptable payment and 4) promote transparent land documentation by collaborating with customary people and experienced private land documentation agencies. Furthermore, settlers said to overcome the challenge of continuous farm size reduction caused by these transformations, the state must also legislate lower and upper landholding limits besides which defined categories of settlers cannot hold. This will prevent settlers from claiming too much land at the expense of landlords and vice versa. By this, they all believe land rights security, peaceful co-existence and food security can be promoted.

The satellite images in Figure 19 show that housing development in Kunfabiala between 2006 and 2018 seems minimal. This may defeat the direct influence of urbanisation solely changing customary tenure in terms of land availability and rights. FGDs revealed that the expectation for urbanisation characterised by physical development has prompted land demarcation. The result they confirm is that settler farmers now resort to land encroachment to farm for 
their household food supplies. To settlers, these point to some need for adopting a combination of socio-cultural, legal and administrative participatory land management interventions that can be referred to as responsible in the short to medium term to address land rights and tenure insecurity. FGDs also raised that government should prepare and implement development plans that cater for subsistence farming even in urban areas to minimise the threat of food insecurity. The medium to long term was emphasised, since development will definitely catch-up in all these communities (whether urban or rural) sometime in the future.

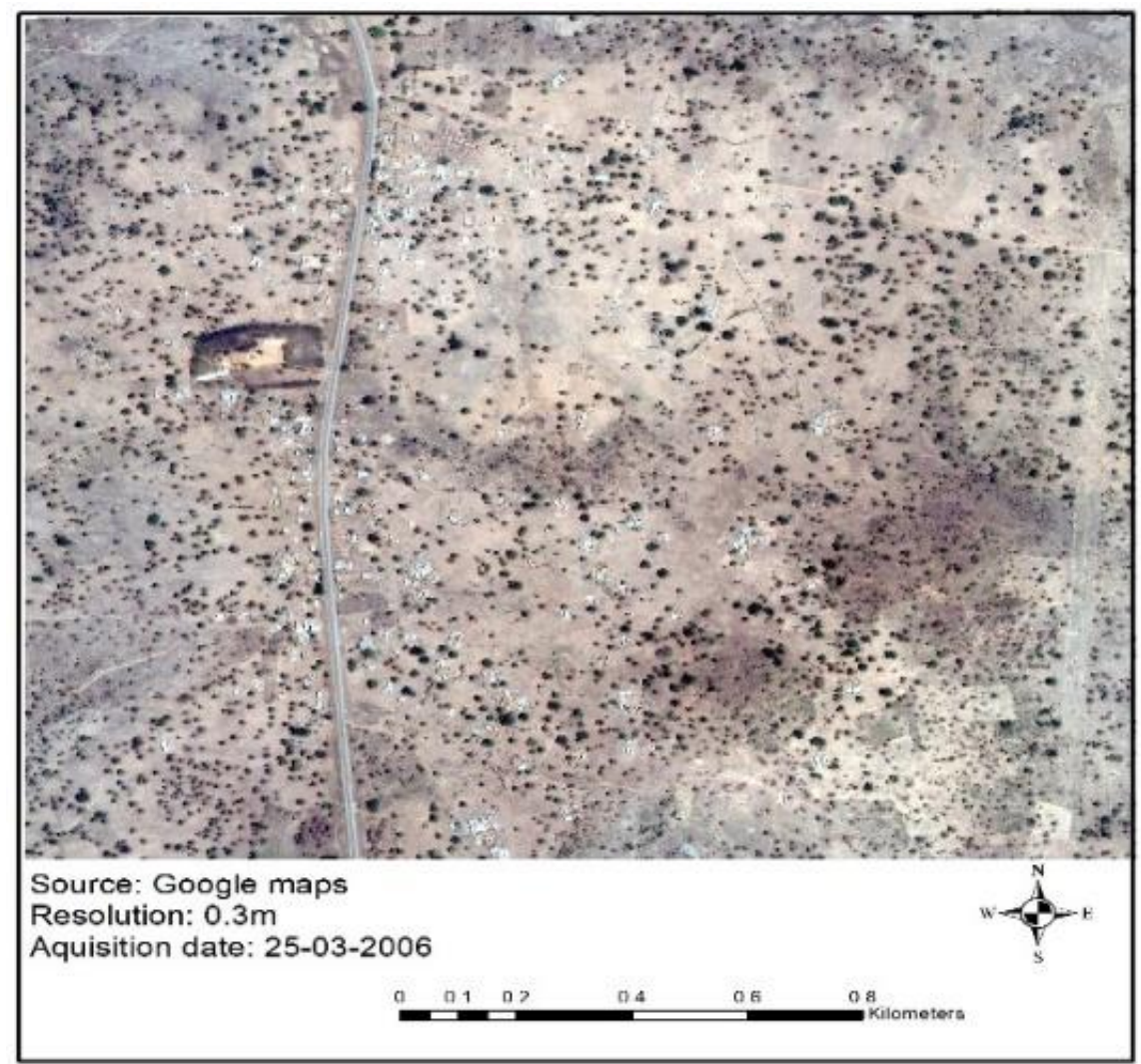

Figure 19 Building development versus land availability 2006 (Adapted from Google Earth Pro) - Identical to Figure 8 


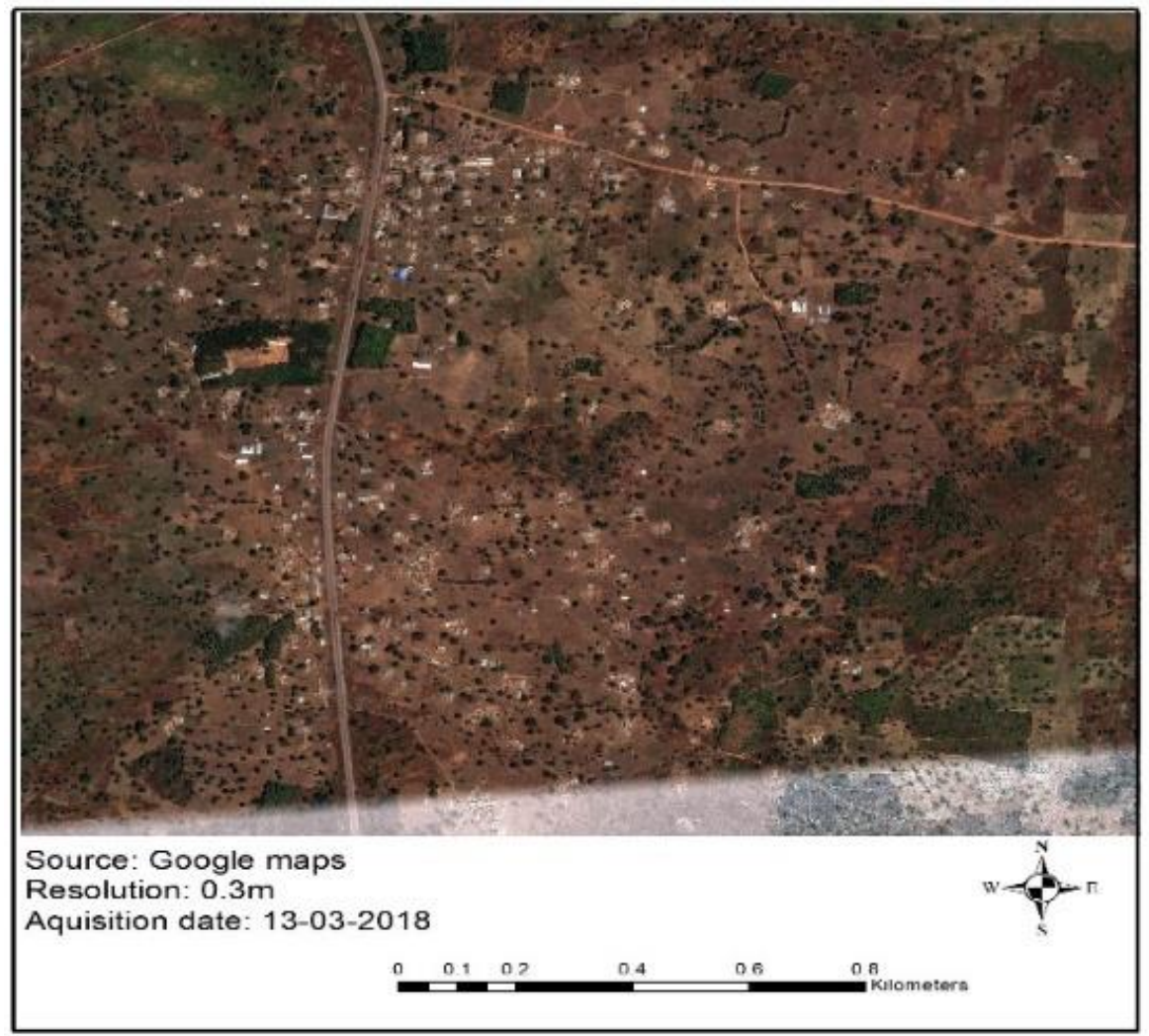

Figure 20 Building development versus land availability 2018 (Adapted from Google Earth Pro) - Identical to Figure 9

\subsection{Local perception of food security and land rights changes}

Pinstrup-Andersen, (2009) identifies transitory and permanent food insecurity. The former is periodic while the latter is long-term food insufficiency. Food may be secured through production, borrowing, exchange, purchases or food aid properly processed and stored. Meanwhile from the FGDs, food security is fundamentally the production and availability of food in the household for their consumption from one harvest to the next. They believe that food availability through production or purchase provides food security. For the people, since physical, financial and even social challenges can hinder access to food from market, they rely largely on their own food production. This is also because food can be secured (i.e. premised) on land rights and tenure security (Holden \& Ghebru, 2016; Nguyen, 2014; Savenije et al., 2017). This was confirmed by respondents when one in Kunfabiala remarked rhetorically that:

'if you lack land, on what will you farm to produce your own food?' 
So, it came out during the FGDs that with secure tenure and other land related opportunities like mortgage, transfer and credit access, it may facilitate increased farm investments and food production. Therefore, weakening land rights and tenure security can affect farming and food availability. Figure 21 illustrates the diminishing food production and reduction of monthly food availability trends as land rights weaken and tenure becoming insecure. This spanned over 3 decades since 1983 at the creation of northwest as Upper West region which may have activated land transactions and showed prospects of land value increases. This situation makes the drive towards responsible and fit-for-purpose land management a step in the right direction.

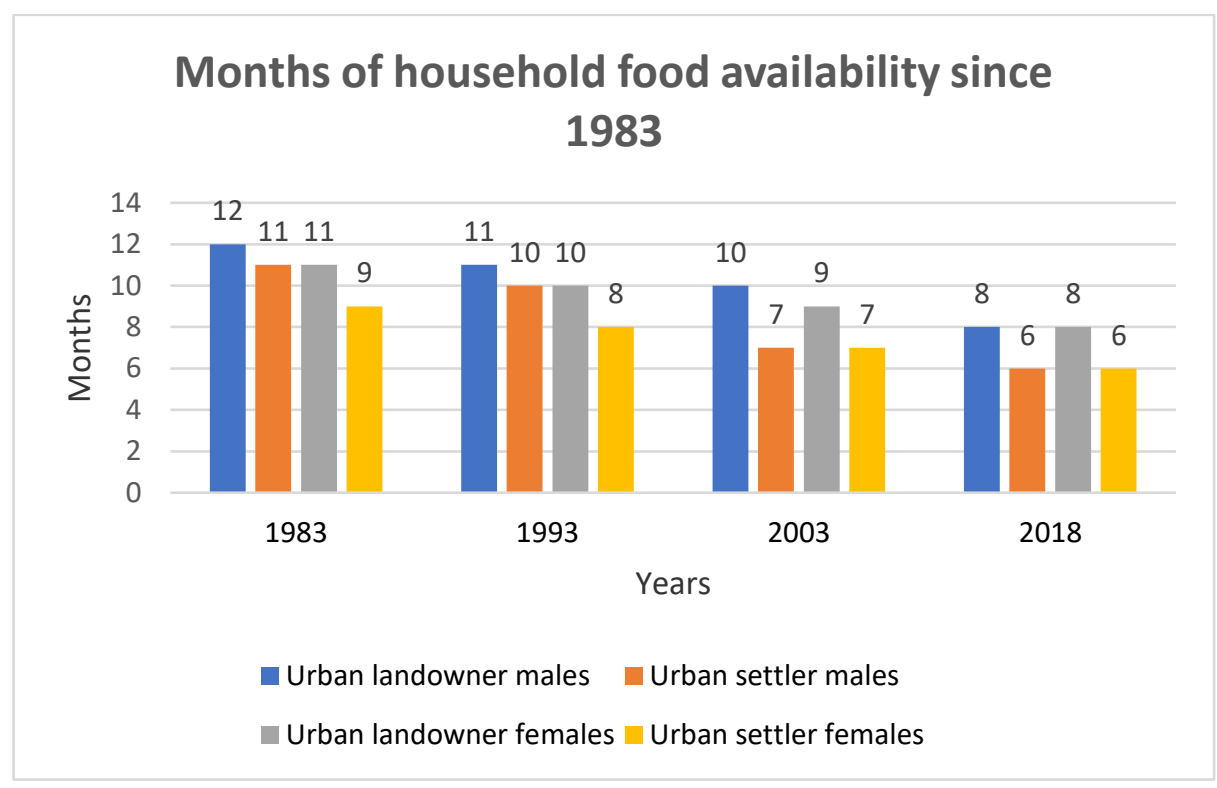

Figure 21 Monthly trend of food availability. (Author's construct, 2019) Identical to Figure 15

Figure 21 shows transitory food insecurity since household food stocks last up to 8 months. There are other challenges to food security which (landowners) mentioned to be non-use of modern farming inputs followed by army worm epidemic, erratic rainfall and post-harvest losses. The landowners asserted that in the past, they could manage their food stocks to last until the following season. They therefore had some surplus to sell and buy foods they do not grow themselves. So, streamlined tenure, they hope, can assure people of reaping the benefits from their investments for which reason they will invest more by using modern inputs to increase production. But settlers in Piina number 2 stress that:

'with tenure security assured, the current size of our landholdings [small as it maybe] will suffice since we will buy and apply chemicals - fertilizer, pesticides 
and weedicides to increase yield. In the absence of these chemicals, we need large parcels of land to produce more. Now that we seem to be under siege, the worst is feared and 'only bulldozers can move us out [an indication of resistance]."

\subsection{Discussion}

Holden \& Ghebru, (2016) emphasised that secure access to sufficient land is an important means of promoting subsistence farming and achieving food security on customary lands. But Rao, et al., (2016) indicated that there are currently weak laws to regulate various aspects of land and either formal or local customary laws were not adequately used. Even though legislations can contribute to high level of land tenure security in formal environments, they sometimes fail to protect some categories of local farmers (Barry \& Danso, 2014b; Deininger \& Jin, 2006). This study contends that food insecurity occurs partly because of non-adherence to customary and formal land laws, and overgeneralising formal laws by disregarding context differences. For instance, the land tenure system in the study area operates on moral considerations rather than for profit or commerce. External influences have now introduced commercial-for-profit potential on land. Coupled with weak local land governance and poor implementation of national land laws, this threatens tenure security and consequently food security of all subsistence farmers in varying degrees (Barry \& Danso, 2014b; Ho, 2001). This is supported by Barry \& Danso, (2014) that existing formal land laws in Ghana were enacted without considering the unique context of users. For this reason, landholders (especially owners) do not find current land laws very beneficial to them. Landowners therefore disregard these laws with almost no legal consequences since tenure arrangements are not documented and scarcely enforced by formal laws. Available literature emphasise that documentation alone cannot secure land tenure especially in environments with weak legal framework and institutional capacity and commitment (Zevenbergen et al., 2013). FGD respondents also insist that their perceptions alone no longer provide customary tenure security except for landlords (in few instances) because it is the courts that have finality on all land litigations in Ghana. Furthermore, women and settler respondents indicated that their land rights are no longer secure based on the customary practices, norms and guarantees alone.

Even though local people recognise that other factors influence food security, they are convinced in line with (Lawry et al., 2014; Ruerd \& Policy and Operations Evaluation Department (IOB) Ministry of Foreign Affairs, 2011; Savenije et al., 2017) that the primary factor is land rights and tenure security that enables them to farm their own food. It is especially true in this case because the local people confess that they do not possess alternative skills based on which to increase farm investment or diversify their food supply sources. Also, respondents concluded that if there is no means to farm their 
own food, it implies they particularly will have weak financial power to access food from the market. As a result, women but especially male settlers said they welcome efforts to intervene in their tenure insecurity to facilitate their continuous farming for their food supply and security. Even landowners agreed that perception alone is no longer sufficient to secure tenure because there is risk of unfair changes in future to the detriment of succeeding generations.

This therefore bridges the land rights and tenure security controversy in the literature regarding perception by (Bugri, 2008; Simbizi, Bennett, \& Zevenbergen, 2014), documentation by Cotula \& Toulmin, (2004) and registration by Zevenbergen et al., (2013) to secure land rights. The reliance on either perception or documentation for land rights security in part depends on whether one's land rights are primary, in the case of landowners or secondary in the case of settlers and women. This is clear on the ground as the people of Fielmua regarded as settlers, insisted based on perception and de facto possession that their land tenure is secure. But this claim is immediately in question as it is being challenged in court by their original landowners, meanwhile, the court has freedom and finality to rule for or against. The current generation of both Fielmua and Nimoro have never witnessed the performance of any tenure services between the two peoples in their life. Yet Nimoro people (original landlords) believe there is need to reactivate receipt of tenure services and 'gifts' from the people of Fielmua (late comer settler 'landowners'). But the people of Fielmua rather find this as a reintroduction of a practice that ended mutually by both groups' ancestors long before any of the current settler and landowner generations were born. Based on the above discussions, further research is required to identify the most appropriate, effective and efficient interventions which respond to responsible land management.

\subsection{Conclusion and policy recommendations}

The research objectives focused on addressing tenure challenges with locally based approaches to promote farming and food security. Agriculture is a main economic activity in northwest Ghana and access to land is a fundamental means for food supplies. In the short to medium term, changes in land tenure systems may produce winners (urban landowners gaining money from land sales) and losers (women and settlers losing farmland). In the long-run, all the people may lose out when these disagreements escalate. Both groups do not completely adhere to local intervention structures/avenues to address tenure insecurity issues due to discriminatory customary practices, weak formal land laws and non-speedy adjudication in courts. This does not encourage compliance to either law or custom to address land rights and tenure insecurity. Recurring disagreements arising from weak institutional and legal system and non-documentation of customary arrangements governing land tenure raises inherent weaknesses in a transforming society. 
In spite of its inherent relevance in making land available to many people in the area, customary tenure system is challenged. And so government intervention is still required in line with responsible land management through further research into blending formal legal recognition with local involvement. In this way, current land rights are ensured but future needs for land are not compromised. Documentation with state facilitation and active participation of users can promote future land rights and tenure security thus making land management more responsible. Furthermore, the involvement of private players, closely monitored by government is vital for tenure documentation thereby making land management more responsible (based on Meridia's successes in other parts of the world and Western region of Ghana). Legal protection of previously obtained land rights based on customary arrangements may sanitise local land access and tenure security. It is especially so, for marginalised groups like women and male settlers. Legal recognition of existing land rights and locally based institutions like Customary Lands Secretariats (CLSs) using alternative disputes resolution (ADR) mechanisms to secure tenure are equally relevant for responsible land management interventions. Land management can also be responsible if it involves all stakeholders in resolving land rights and tenure challenges. For instance, the formal laws can mandate CLSs to settle related disputes such that cases referred by them should be allowed to be heard in court in order to eliminate the numerous unresolved land cases in Ghana's courts for decades (Biitir \& Nara, 2016). The dynamics influencing tenure security are unique. This calls for a process to design and implement context specific participatory responsible land management interventions for each spatio-cultural setting. The customary dimension of land access, land rights and tenure security may promote their own farming for food supply and food security. This chapter advocates documentation of community-based land rights backed by law with strict legal enforcement since local people now voluntarily accept that land documentation can strengthen their land rights and secure tenure for the future. The people have therefore suggested that the state through its representatives like the courts, quasi-judicial bodies and Lands Commission (LC) should collaborate with CLSs, customary leaders and institutions to legislate and regulate an appropriate locally acceptable hierarchical land management structure. This makes land management responsible, since all stakeholders' needs may have been incorporated into it to meet the land needs of both current and future generations. 


\section{Chapter 5 Designing responsible and fit-for- purpose (FFP) customary land rights and tenure model for food security of smallholder farmers in northwest Ghana}




\subsection{Introduction}

Customary areas in Africa and other parts of the globe experience increasing inequalities on land rights and tenure security, which may reflect the social structure upon which they share these rights (Lipton \& Saghai, 2017; Van Vliet et al., 2015). Disputes between landowners and secondary rights holders is usually rooted in the precise content of land rights and duties transferred to such rights holders, and based on the local land rights and tenure model in use. The inherent processes, procedures and arrangements were said to be under control during the colonial and early post-colonial years until recently when lands became monetised (Peters, 2009). The consequent tenure insecurity emanates from the fact that during the past few decades, related conflicts have surfaced. The tenure insecurity then persists as landowners contest past land transfers. The contestation is usually against existing land rights and tenure models (or attempts to unilaterally vary them), in order either to receive a land rent or even to reclaim the land (Peters, 1997, 2009, 2013b) from secondary rights holders who are mostly migrants known generally as settlers in the context of Ghana.

Land rights inequalities and its consequent tenure insecurity impede desirable productive land use say, for farming activities of especially marginalised secondary land rights holders, including women (Azadi \& Vanhaute, 2019; Duncan \& Brants, 2004). Thus, land rights inequalities tend to hinder land use potential of people to achieve desired outcomes. The outcomes in customary areas relate to farming for food supply to sustain their families on largely smallholder basis (Lipton \& Saghai, 2017). The expected benefits from land in the midst of weak rights to its challenges subsequently declines thereby compounding communities' problems of livelihoods, food security, general development and wellbeing (Azadi \& Vanhaute, 2019; Lipton \& Saghai, 2017; Wegerif \& Guerena, 2020).

Food security strategies such as commercial production, food distribution through the market and food aid still need to be supplemented because many hungry people have not been reached yet (FAO IFAD UNICEF, 2017; Holden \& Ghebru, 2016). Meanwhile, in many developing countries more equal distribution of land is key and yet an often-neglected policy option. And so state-led land reform of some sort remains a major ethically defensible route for addressing food insecurity and related disadvantages (Boudreaux \& Sacks, 2009; Lipton \& Saghai, 2017). Therefore, minimal non-costly interventions may be sufficient for subsistence/smallholder farmers to produce enough food for at least the household. Interventions for securing land rights and tenure so far have not been sufficient to provide the needed impetus for all categories of people to farm for adequate food supply. For instance, the current approach of registering land to secure it, is deemed too expensive for the poor 
(Zevenbergen et al., 2013). Yet, seemingly little attention is paid to the negative implications of replicating western-based models of land tenure in sub-Saharan Africa which yield minimal outcomes (Lawry et al., 2014; Mulolwa, 2002). This implies that the question on what tenure strategies will work well in African customary areas remains unanswered. As such, some inputs are required to design and implement an effective and fit-for-purpose (FFP) land rights and tenure model. The FFP concept according to Enemark (2017); Enemark \& Mclaren (2017), is about applying the spatial, legal and institutional methodologies that are most fit for the purpose of enhancing land tenure security for all by addressing the current constraints while allowing for incremental improvement over time. This assertion guided the collation of user requirements and literature materials to design the land rights and tenure model in this research for securing land tenure and consequently to encourage more farming investments towards food availability and food security (Nguyen, 2014; Nguyen et al., 2016).

The purpose of this study is to represent the qualitative relationships in the form of a land rights and tenure model. This research paper examines, adapts and integrates other working models with current local land rights and tenure model by blending feasible components of both. The result is a new model designed to help strengthen land rights and improve tenure security. This could in turn reduce tenure disagreements or related conflicts and land rights inequalities thereby promoting a conducive tenure atmosphere for livelihood activities - farming for food security.

Sections one, two and three contain the introduction, literature review and methods while sections four and five contain results and discussion respectively. Finally, the conclusion and recommendations are contained in Section six.

\subsection{Literature review}

This section in 2.1 reviews literature on requirements for an effective model in general, 2.2 is on factors for the design of a food security model and finally 2.3 on factors to consider in designing a land rights and tenure model. This exercise aims to contribute to knowledge in the design and implementation of models for improved ways of resolving communities' land rights and land tenure issues. It may then ultimately facilitate the productive use of land for various purposes including farming for increased food production, food availability and food security. 


\subsubsection{General requirements for modelling and tenure security}

A model may refer to a pictorial or graphic representation of key concepts designed based on perceptions, lived experiences, opinions and aspirations of affected people reasoned out symbolically (Forbus, 2008). These models may be visual, mathematical or computer based. Visual models are mostly used in qualitative research and include flowcharts, pictures and diagrams. Qualitative models may also represent perceptions symbolising natural states of incomplete knowledge or minimal information to draw useful inferences from those states of knowledge. Predictions made from qualitative models are often not full-proof and this makes qualitative models ideal to ascertain which of several possible behaviours will occur in the administration and management of situations e.g. land rights (Forbus, 2008). In a nutshell, models guide how to resolve specific challenges that people face in the context of their daily living and environment.

Governments have a legitimate role in regulating and administering land rights due to the related importance of land in the economy for people's livelihoods (Azadi \& Vanhaute, 2019; Peters, 2009, 2013a; Toulmin, 2008; Wegerif \& Guerena, 2020). To make models effective therefore, legislation may provide some degree of protection for local land rights in a weakening customary practice (Chauveau, Cissé, Colin, Cotula, Delville, Neves, Quan, 2007). For example, where customary systems' authority has declined due to social, economic, cultural and political change, government's intervention may be needed to provide effective land management. However, even where customary systems seem to work well, government intervention may still be required to safeguard against potential abuses and to secure the resource claims of weaker and more vulnerable groups (Cotula \& Neves, 2007). Otherwise, such groups (smallholder farmers) can face the threat of food insecurity as a result of land tenure insecurity. Thus, an indication that legislation is a vital requirement in an effective land rights and land tenure model. Also, the effectiveness of such models can be partly dependent on a land administration function of information collation and dissemination for awareness (Ballard et al., 2013). Therefore, Bugri (2010) emphasised the use of local customary mechanisms in addition to other forms of information gathering and sharing. And that this awareness can be created using current media platforms i.e. mainstream, customary or social to speed up information sharing that can stimulate swift actions towards redress.

Various governments' interventions to strengthen land rights and secure tenure may not have had satisfactory success in sub-Saharan Africa, except registration success in Rwanda and Namibia (Fosudo, 2014; Simbizi et al., 2014). Meanwhile, change that may cause insecurity to customary tenure is inevitable due to different pressures such as increasing population, urbanisation and changing ideologies, local practices and local laws (Mulolwa, 
2002). The failure of interventions accordingly, stem from imposition of foreign-based tenure models on local people without recourse to peculiar local circumstances (Capaldo, Karfakis, Knowles, \& Smulders, 2010; Lovendal \& Knowles, 2006; Mulolwa, 2002). An adaptive framework for managing land rights and land tenure provides a useful alternative (van Asperen \& Mulolwa, 2006; Mulolwa, 2002). Models are often used to present essential information, to allow for easy understanding and to enable formal description (Weißleder \& Lackner, 2013). These models can be locally initiated, thus co-created. Cocreation involves the active participation of local people to design solution strategies that represent communities' felt needs and aspirations on specific challenges, sometimes described as the bottom-up approach to development (Galvagno \& Dalli, 2014; Ind \& Coates, 2013). That is, adapting a model with grassroot initiation and active participation (Ind \& Coates, 2013).

To address weakening land rights, NGOs like COLANDEF-Ghana and Landesa Rural Development Institute-Ghana also work with the local people (Landesa Rural Development Institute, 2016). COLANDEF-Ghana facilitates stronger land rights through advocacy, capacity building for customary land authorities and education on land rights in the country (Landesa Rural Development Institute, 2016). Landesa partners with various governments and local organizations worldwide, to secure legal land rights for needy families including in Ghana. Since 1967, Landesa is reported to have helped millions of poor families globally to gain legal control over their land (NAMATI Innovations in legal empowerment \& Institute, 2015). It appears however that in spite of these activities, the impact is yet to reach many marginalised families and groups in local communities in Ghana including this study area. Landesa further works to facilitate design and implementation of land laws, policies and programs that provide opportunity, further economic growth, and promote social justice through land rights (Kumar, 2013). Their reported success rate shows that it is possible to replicate this approach in other yet-to-reach contexts like Ghana's northwest in particular and reveals a valuable synergy that is relatively less utilised. This implies that the involvement of outsiders like NGOs in model design and implementation is also paramount.

This study therefore contributes to food security through strengthening land rights and securing land tenure by blending customary norms and statutory laws in a fit-for-purpose land rights model. This research contribution is important because land-based largescale investments in Ghana is recognised by the government to hold potentials for enormous benefits. And also pose some risks to local people and livelihoods of smallholder/subsistence farmers (Kelkar, 2014; Kumar, 2013; Renée, Richardson, \& Elisa, 2016). Hence, designing an appropriate model to address food security challenges using land rights and tenure issues in this study seems plausible. 


\subsubsection{Designing a model towards achieving food security}

According to Chigbu \& Klaus (2013), food security can be achieved through sustainable ownership, use and management of land resources. Also, the Food Safety and Inspection Service of the US Department of Agriculture (FSIS), (2005); Capaldo et al., (2010) observed that (land rights and tenure) risk management strategies are needed to deal with food security. Implying that secure livelihoods from farming with secure tenure can lead to sustainable poverty reduction and improved food security (Kuuire, Mkandawire, Luginaah, \& Arku, 2016). Furthermore, the things many rural and some peri urban families readily do with land in order to make a living is to invest in farming activities (Kuuire et al., 2016; Nguyen, 2014; Nguyen et al., 2016). These farming investments can lead to improved food security too. Subsistence migrant/settler farmers' assets primarily revolve around access to land resources and their own farming skills (Kuuire et al., 2016). Therefore, weak land rights and insecure land tenure can pose threats to their food security and thus stress the need for a strategy/model to solve their food shortages. Designing a harmonized land rights, tenure security and food security model for this context is imperative as the FAO et al., (2015) found northern Ghana to be the most food insecure place in Ghana.

This model focuses on land-people-institution interaction. For Capaldo et al., (2010), risks and risk (land tenure) management strategies will interact with current food security characteristics to produce future food security outcomes. And so, they identify "risk management actors" (e.g. government and landowners) and "risk type" (e.g. tenure insecurity). These enable a synthesis of a combined land tenure security and food security model as modified (Chigbu \& Klaus, 2013). The model seeks to strengthen land rights and enhance tenure security, which can then encourage increased investment in farming and subsequently (in addition to other inputs), improve food security (Kuuire et al., 2016; Nguyen et al., 2016).

It has been posited that weak institutional control measures and poor enforcement of tenure laws can negatively impact development in general (Denzau, 2015; Ferrini, 2012). A situation that can encourage non-compliance to customary norms and practices, and can lead to land tenure insecurity among the predominantly agrarian smallholder (migrant/settler) farmers. This research outcome will facilitate efforts leading to stronger land rights and secure land tenure, which can further lead to secure food, particularly its availability and accessibility. And can also contribute to improve nutrition and food stability.

\subsubsection{Designing land rights and tenure model}

Land tenure, according to van Asperen \& Zevenbergen (2007), refers to the social relations between individuals and groups of individuals in which rights 
and duties are defined in the pursuit of human aspirations. It is important for power brokers (in this case, statutory institutions and customary landowners) to be explicit about the tenure processes in order to facilitate enforcement and compliance. Thus, Boudreaux \& Sacks, (2009); Lipton \& Saghai, (2017) stressed that effective protection by governments and other authorities or institutions can strengthen land rights and enhance tenure security. User requirements from local land users (i.e. subsistence farmers) are necessary components in a model that will be responsive to user needs (Almeida \& Wassel, 2016).

In van Asperen \& Mulolwa (2006), earlier interventions failed because they merely replaced the traditional tenure arrangement with a completely different one from elsewhere. Therefore, when weaknesses are found in a system, it is prudent to adjust and improve it because users may be more familiar (and find it easier to work) with an improved version of the existing system than a completely new one (Mulolwa, 2002).

This research will adapt Vulnerability to Food Insecurity model (Capaldo et al., 2010; Lovendal \& Knowles, 2006), Unified Land Tenure model by Mulolwa (2002) and Land Tenure and Food Security model (Chigbu \& Klaus, 2013). The new model will further incorporate local land user requirements and the outcome is expected to promote local land use especially for farming to produce more food that can help promote food security.

\subsubsection{Food security manifestations and dimensions}

Food security is described as a situation in which "all people, at all times, have physical, social and economic access to sufficient, safe and nutritious food that meets their dietary needs and food preferences for an active and healthy life" (AEC, 2004; Ballard et al., 2013). In other words, it refers to the capacity to provide sufficient food through production, acquisition and distribution on sustainable basis. This understanding of food security implies that eradicating hunger requires increases in the availability of and accessibility to sufficiently nutritious food from one harvest to another (Nara et al., 2020a). The extent to which subsistence/smallholder farmers are able to increase their food security depends in large part on the opportunities they have to increase their access to assets such as land (Nara, Lengoiboni, \& Zevenbergen, 2020b; Ruerd \& Policy and Operations Evaluation Department (IOB) Ministry of Foreign Affairs, 2011).

Smallholder farmers throughout the world continue to experience displacement from their lands, struggle to remain viable and often experience hunger (Carte et al., 2019). According to the Food and Agricultural Organisation (FAO), factors that enable progress towards improved food security and nutrition goals are agricultural productivity growth, functioning markets, and effective social 
protection possibly through an effective form of legislation (Nara et al., 2020b, 2020a). This makes land, its rights, associated inequalities, and varying tenure security important in this research. Furthermore, the food needed to boost global food security comes from not only large-scale commercial farming but also small-scale agricultural activities (Conway, 2011; FAO et al., 2015). The supply of food to smallholder households in order to meet all dimensions of their food security needs is mainly through own farming. In addition, they purchase from the market what they do not produce from sale of some of their own farm produce (Nara et al., 2020a).

These food security dimensions are: 1) physical availability in sufficient quantities, 2) the ability to regularly access needed food through purchases, barter, gifting, borrowing or food aid, 3) effective food utilization and finally the 4) maintenance of the desired properties or nature of food overtime such that it remains safe and pleasant to consume i.e. food stability (FAO et al., 2015). It is argued that food security can be greatly facilitated when access to land, land rights, and tenure security are guaranteed leading to increased investment in farming especially in sub-Saharan Africa (Nguyen, 2014; Ruerd \& Policy and Operations Evaluation Department (IOB) Ministry of Foreign Affairs, 2011). This is especially so for smallholder farmers who depend directly on the land for the majority of their food supply. The availability and accessibility dimensions of food security are especially relevant in this research, though not losing sight of the stability and utilisation components (Nara et al., 2020a). There is a recognition of broad implications for food insecurity that land rights inequalities and tenure insecurity can contribute to (Federal Ministry of Food and Agriculture (BMLE), 2015). The evidence in the literature suggests that strong land rights and tenure security are essential for food security (Bugri, 2010; Lawry et al., 2014; Nara et al., 2020a). Of course, Nara et al., further opined that this exposition above does not necessarily imply that strong land rights and tenure security will automatically translate into food security. Rather, some other factors or inputs must be combined with strong land rights and secure tenure, which may then lead to improved food security outcomes.

What is happening currently in the study area is relevant for Ghana in the sense that whereas the country may be doing well in terms of food security, its (five) northern regions remain the most food insecure places in the country (FAO et al., 2015). This can significantly undermine Ghana's efforts towards achieving its long-term food security goals (Nara et al., 2020b). There is therefore the need to contribute to curb the country's food security challenge with the design of a responsible and fit-for-purpose (FFP) land rights and land tenure model which this research seeks to do. 


\subsection{Methodology}

The research adopted the qualitative approach involving the following data collection tools - focus group discussions (FGDs), key informant interviews, joint community workshops and community forums. In all, there were 388 FGD participants, 36 FGDs of between 8 and 12 people in each group covering six communities (Hancock et al., 2009; Kothari et al., 2014). They are Sing and Kunfabiala in Wa municipality, Piina number one and Piina number two in Lambusie-Kaani district, and Fielmua and Nimoro in the Sissala west district.

Firstly, the target population was stratified into groups of indigenous landowner and settler settlements in the communities. Then for the FGDs, the people were grouped according to gender. Within each gender group, there were subgroups made up of disabled, elders and youth/middle-aged. Selected key informants also provided additional information not privy to other members of the community, which guided the discussions during subsequent meetings. After the FGDs, representatives from all the sub-groups under each gender type were selected for further discussions to fine-tune the issues raised during the FGDs. Thereafter in joint community forums, participants used consensus building to agree on the issues that constitute their processes of resolving land rights and tenure security challenges that confronted them in their various communities. These challenges exist between landowners and settlers or among settlers but rarely among landowners themselves. In separate community forums, a cross-section of community members attended for briefings by workshop attendees. The larger community gathering then made inputs while serving as effective channels to also sensitise other absent members in the fora for increased awareness on the community's own processes for addressing land rights and tenure challenges. This also included the challenges they encounter in the process and the influences on their efforts to farm and secure food. Furthermore, members in the various meetings put forward suggestions to address these challenges by proposing modifications to the current model to make it more efficient and effective.

The local people described their current land rights and tenure model, and the challenges of operationalizing it. After this, they built consensus suggesting the kinds of improvements they would want to see in their current model in Figure 22 in order to strengthen land rights and secure tenure in Figure 23. Before they detailed the nature of their desired model, they jointly (with researcher) examined other models (Boudreaux \& Sacks, 2009; Capaldo et al., 2010; Chigbu \& Klaus, 2013; Lovendal \& Knowles, 2006; Mulolwa, 2002). These models touch on government protection of vulnerable groups, food security linkages, connection between food security and land tenure security and locally sensitive land tenure intervention issues. Local views and suggestions based on consensus were received on the aspects of these different models the communities would want to be included in their own model to possibly enable them achieve their felt needs and aspirations. These aspirations being strong 
land rights, secure tenure, food security, sustainable livelihoods and development in general. The study (i.e. data gathering) was conducted in phases:

Phase 1: The first part of the process used FGDs to solicit community views, experiences and ideas. It was based on consensus building towards adjusting their current model and for designing a new holistic one. Each FGD session was used to elicit initial information from people about the kind of land rights and tenure model being used in each community. They also revealed the kinds and nature of challenges they face in the use of the model. In addition, the FGDs suggested feasible adaptation measures to develop a new, improved and more efficient model. Apart from that, 12 key informant interviews were conducted. The key informants provided information on the rationale for the requirements in the current model in the first place. They also detailed why it is currently less efficient in strengthening land rights or securing land tenure and therefore deficient in contributing to food security.

Phase 2: There were also three joint community workshops with 12 participants each (i.e. comprising settlers and landowners in the same unique customary jurisdiction). The joint workshops enabled the different categories of people using the set of rules, practices and norms in the model to reach consensus regarding petit divergent suggestions.

Phase 3: The consensus reached at the joint workshops were later conveyed to the larger communities through separate community forums. There were also 12 community forums with participating numbers of between 30 and 50 people at a time. Members had the opportunity to make suggestions for finetuning of outcomes from the workshops. Specifically, all participants discussed the following questions/topics in line with research sub-objectives.

i) Choosing an appropriate model for securing land rights/tenure and for promoting farming. Types of models, practices, customary laws etc. of the communities.

ii) User requirements for designing appropriate land rights and tenure security model based on the question: What are the challenges of your current land rights and tenure model?

iii) Adapting from other models led to the question on what possible changes will affect the current model to obtain a new one that is fit-for-purpose. The discussions touched on what roles and responsibilities individuals, groups and institutions play in current model or will play in new model in order for communities to realise their common aspirations of stronger land rights for all.

iv) Responses on the above topics derived from the research questions were built on to address the key objectives of this research. 


\subsection{Results}

This section presents the findings based on community's (respondents/research participants) lived experiences and joint literature review by local people and the researcher.

\subsubsection{Designing, modifying and adapting an appropriate model}

This research was to ascertain the current strategies (in the form of a model) employed by the communities to resolve their land rights and tenure security challenges. Before commencing the process, the FGDs discussed other models (mentioned above) used in other jurisdictions in Ghana and outside. They then compared their own model with those of other places in order to identify which aspects are working well or not and how these can be modified based on their efficiency elsewhere. It enabled them to assess the ineffectiveness of their current model whilst proposing an alternative model for improvement using these other models as a guide. For instance, questions to this effect were: what kind of model is in use where, and how do they adequately address specific aspects of your land rights and tenure difficulties? Also, whether it enables them to achieve their ultimate human aspirations as smallholder farmers, which is food security in terms of availability and accessibility including nutrition and stability. The results in Figure 23 show that there is an existing model in place but practically abandoned due to identified difficulties and disorder in its operation (explained later). The people explained that the procedure in the current model lacks compelling powers for compliance. As such, some people choose which aspects to obey or not and yet are not punished for any violations.

For instance, the head of landowners known as tengansob of Fielmua, tendana of Sing or tortina of Nimoro and Piina number 1 separately expressed similar sentiments.

One landowner from Piina said:

"The problem confronting us is that modernisation, religion, urbanisation and education have virtually distorted our hitherto, efficient customary system. Especially when the land rights and tenure challenges concern adjourning landowners/communities" Another interjected, "sometimes, even if they are between landowners and settlers."

Also, in the words of a landowner from Sing:

"Most youth/middle-aged do not respect our customs anymore. The national laws have "tied our hands to our backs" [restricted us] such that elders can no longer compel anybody easily to appear before it. In the few instances where some people (especially settlers) accept to appear before the elders, they choose whether to comply with customary rulings or not. This is because customary norms are increasingly not binding. Rather, national laws have 
become supreme and binding on all irrespective of whether the outcome favours one or not. We sometimes opt for that (through the courts) in more complex tenure challenges." Another landowner concluded that, "since the youth seem to respect the courts more, we can only work together with the courts to secure land rights going forward."

A landowner from Nimoro remarked thus:

"You know my son [referring to researcher], that land cases that use national laws in the courts take such long time to be settled and may never be resolved, at least, not yet. The delay is such that sometimes the courts pronounce final verdicts after original lead parties have died already. A second landowner continued, "can you imagine that the land case between Nimoro and Fielmua has taken over five years with no certainty of an end to it soon? This reduces the relevance of the adjudication process and verdict and its implications for securing land tenure, farming and other livelihood activities." Another continued, "we therefore propose a proper integration of both customary and statutory systems and processes to facilitate effective resolution of land rights and tenure issues. What is needed is a compulsory process properly legislated and continuously publicised for each one's land rights and responsibilities to be known as well as the responsibilities of other bodies and institutions. This we think can facilitate the realisation of stronger land rights and secure tenure for all categories of landholders."

The FGD participants also suggested the inclusion of the media for wide sensitisation of the model in terms of laws, their integration, violations, penalties and resolutions among others. They believe that once everyone is aware of the existence and operation of integrated laws, practices and procedures or hierarchical structure for resolving land rights challenges, they will likely comply. To this, one settler farmer, speaking for the rest expressed thus:

"The government has to make a "big law" [an overarching legislation] that captures everything in the current model [in Figure 22], in addition to explicit and implicit roles for all stakeholders. These will include landowners, settlers, media, courts, LC, CLSs, legal advocates in paralegal bodies, chiefs etc. Yes, we want the overriding legislation to encapsulate the current model into a new model and make it compulsory for all to use it. You know that we as a society now all accept the verdicts from courts as final even when they are against us. Our 'fear' of government structures and media exposure will compel compliance to this new arrangement in the new model."

On how to ensure compliance from all categories of people, another settler farmer further suggested thus:

"Make the new overriding (overarching) legislation to strictly bind everyone to the new model. This legislation/model can make it compulsory for victims of 
challenged land rights and tenure to follow the chain of order for addressing land rights and tenure issues such as challenges, inequalities, arrangements etc. Everyone with any land issue must follow the model from one stage to the next until the court stage as last resort." Continuing from there, another one said that, "after resolution completes, fines payable should be moderate and more flexible so that besides cash, others can choose to pay in non-monetary items like farm produce commensurate with the cash fines. He added that "the law can provide that if someone skips a step, s/he be referred back to it for resolution. To support what the others are saying, another participant concluded that, "this will ease the burden on the courts, as many land rights and tenure disagreements can be resolved before they even get to the court." He further said that, "you see sometimes, some NGOs or benevolent people pay cash fines for us. This way, some people i.e. perpetrators who benefit from such benevolence, do not directly feel the impact of their unacceptable actions. Hence, they keep creating some of the tenure challenges that we face every time. Finally, another clarified that, "if alternative payment options like the use of farm produce and animals to pay are available, people who have to use almost their entire harvest or so many animals to pay fines may hesitate to engage in land rights and tenure abuses. The oldest person among this group summed up by saying that, "when our suggestions are put to practice, the resolution procedure [outlined in Figure 22] for land tenure disagreements can be helpful."

FGD participants noted that authorities in the model who may have an interest in any case would have to be skipped to the next in the hierarchy. In addition, the local people cautioned that no case be allowed to move beyond three stages without a final solution. Otherwise, some unscrupulous people may engage in "forum shopping" i.e. a deliberate tactic to delay the process and frustrate others. This undesirable practice happens under the current model. 


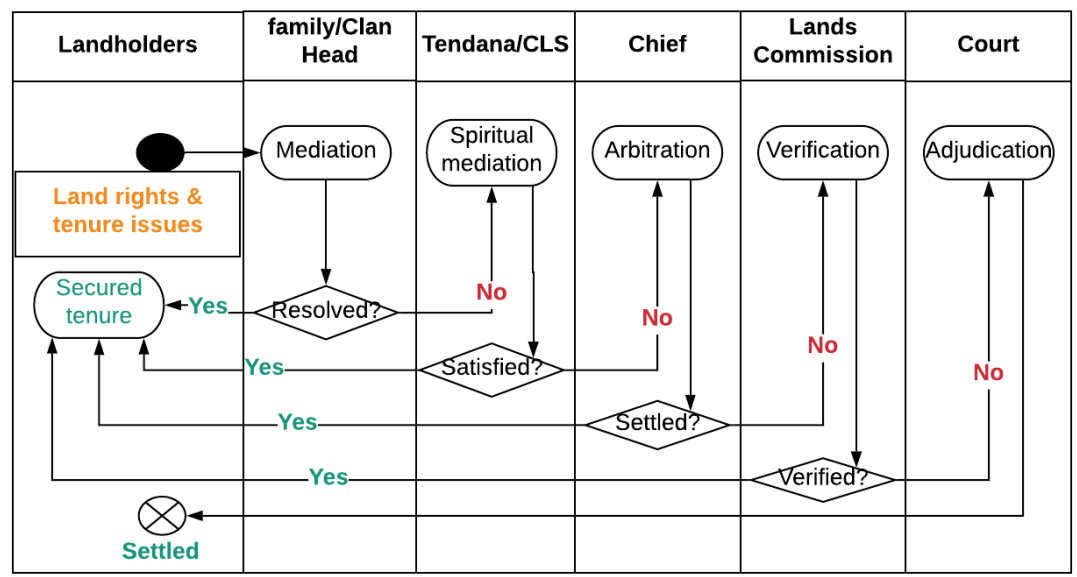

Figure 22 Current customary land rights model in study area. Adopted from Nara et al (Nara et al., 2020b) - Identical to Figure 16

A secure land tenure can make the ownership or use of land more secure, which is very much important for the development of agriculture. Figure 22 represents the current model in the study area. Here, if an individual landholder has a land rights/tenure issue (i.e. challenge, arrangement or disagreement) with another person, the matter goes to a family or clan head. From there if it is not resolved, it goes to a tendana and/or CLS and to the chief where it must be finally resolved. If it is a tendana who has a tenure issue involving civility, he takes it to the chief, LC and court where it must be determined finally. The people find this process to be faulty because there is no law compelling compliance and poor sensitisation from customary, local, mainstream or even social media. Meanwhile scholars have indicated that strong media publicity plays an important role in awareness creation and ensuring compliance. This is why the people call for an overriding legislation to compel compliance followed by sanctions. Then it will authorize media involvement especially with the enactment of the Right to Information (RtI) Act in Ghana. The proposed overriding legislation is also to empower the involvement of legal advocates in paralegal institutions to assist poor, vulnerable and marginalised people seek stronger land rights and secure tenure. Further, the new model in the legislation will implicitly endorse alternatives to cash payments of fines, charges, rents and royalties and include flexible non-monetary options.

\subsubsection{User requirements for designing a model}

Inherent in weak land rights and insecure tenure are land rights disputes, disagreements, claims and counter-claims leading to general uncertainties regarding land transactions, ownership and uses. Therefore, this new model 
presents the processes of land disputes resolution and invariably aims to strengthen land rights and secure tenure and to reduce or eliminate prolonged uncertainties. These tenure uncertainties can affect farming and culminate into food insecurity of smallholder farmers in the study area. Various participants of FGDs gave varied expectations i.e. user requirements for the new model that they consider can be effective in addressing their land challenges and promoting farming for more food availability. The people consider that these will likely promote their accessibility of other foodstuffs they do not grow. They also said it could enhance their nutrition and food stability. For instance, participants mentioned the inclusion of stakeholders like chiefs, media, legal advocates in paralegal institutions, new overriding legislation and nongovernmental organisations (NGOs) in the process (model) for resolving land rights challenges. In general, the participants also support implicit flexibility in land transactions ranging from land allocation, tenure, reasonable land/farm size for all, renegotiation periods, benefits and 'small gift' of land for each one holding land. This is what the youth/middle-aged landowners particularly remarked through one of them:

"The land means everything to us including for the provision of our food needs, so we will put in every effort to ensure that the new land rights and tenure model works effectively. So, we are pleading with you that as you try to help us find lasting solutions to our land rights and tenure security, let the model also be capable of addressing our food concerns consequently. What we want is for the hierarchical structure of land ownership, land allocation, land rights, land tenure etc. needs to show in the new model and known to everyone in the area. We want the new model to be explicit (though in some cases implicit) about land rights, land tenure, land/farm sizes and flexible payment system for landowners." "For instance," a colleague continued, "both cash and noncash payments with farm produce and/or animals have to be included in the model." Another added, "the new model can still maintain the power of chiefs on the people i.e. inhabitants of the land but not the land itself. So that when land conflicts degenerate, chiefs can settle the civil aspects, the courts can settle the criminal aspects while issues directly surrounding land rights and tenure will remain the preserve of the landowners according to custom." And another participant continued that, "we also require some sustained intensive awareness creation among stakeholders. An overriding/overarching legislation can make this awareness creation mandatory, through community gatherings, festivals and the media (whether local, mainstream or social) particularly the radio stations in local languages and dialects." Yet another continued that, "political platforms may also be potent avenues to sensitise and encourage people on the new model. Legal advocates in paralegal bodies like Legal Aid Board ( $L A B)$, Commission for Human Rights and Administrative Justice (CHRAJ) etc. can also get the legislative mandate to support victims of land rights and tenure violations. The legislation reflects in the model to define the roles of Lands Commission (LC) and Customary Lands Secretariats (CLSs). 
Furthermore, all land documentation processes must commence from the CLSs and end at the LC. Both institutions will keep copies of these documentations meant for the client i.e. person(s) documenting the land/farm rights while other copies go to clients."

Migrants/settlers suggested their expectations in a new model through their spokesperson:

"Although customs are good, they do not help much anymore because landowners tend to 'manipulate' them to our disadvantage. For instance, landowners do not negotiate intended land rights change with us (settlers) anymore. All we see is that developers or governments have started development on our farms but our landowners claim innocence. Therefore, we want the legislation reflected in the new model to include documentation, assigning definite periods for renegotiation of tenure (say 5-10 years) prior to which landowners cannot re-enter the land. The overriding legislation (new model) can extinguish all other landowner rights on two-hectare land parcels and below from us migrant/settler farmers except the reversionary interest."

What came out from the disabled FGDs is to maintain equal land rights between disabled and abled-bodied persons in the new model. Their additional concerns expressed by one are:

"Nevertheless, with the increasing commercialization of land, individuals may abuse our land rights in the future (some subtle attempts at that are fresh in our minds now). We hope you [referring to researcher] remember sadly, the Daffiama case where a visually impaired man was butchered for standing up for his land rights. Therefore, what we require in the new model/legislation is that anybody who tramples on the rights of disabled people to receive stiffer sanctions than if they offend abled-bodied people. Yes, that is why we fully agree with the final death sentence verdict of the court for the perpetrator in that particular Daffiama case in the Wa High Court."

One woman suggested to maintain and include in the new model that:

"We women generally prefer compromises in the midst of land rights and tenure disagreements. Customary laws exclude us from owning customary lands and we cannot change that. At least, we prefer formal laws permitting women to own any land if we have the wherewithal (even though women are not financially resourced enough to take full advantage of this). In addition, there are varied customary land rights/tenure like access limitations on different categories of women. For instance, maintain wives 'co-owning' land with husbands in our patrilineal system. And maintain that at the demise of a husband, the widow automatically inherits those lands in respect of the late husband in accordance with custom. And that the widow's land use rights subsist as long as she remains in the late husband's house (as widow) or maybe agrees (but not compelled anymore) to marry a brother of the late husband. 
Another one, a widow, continued that "we know that the widow like other women in the area does not have the right to sell or gift the land but she can exercise other rights by consulting the rest of the family, which holds the paramount allodial title. Maintain also (as in customary tenure), that the widow has strong land use rights even without children. And remove the fact that her rights can only be stronger with children especially son(s). Speaking for matured but unmarried daughters, another woman mentioned that "maintain the fact that sisters and daughters may not exclusively own customary land just like our brothers and sons but women can still exercise use rights. These access rights of sisters and daughters may diminish at marriage as their strongest source to obtain land will now shift to husbands. We also want the new model to forbid the males from re-entering women's lands not earlier than five years. By that time, we may have recouped our investments from the land instead of our males taking back lands after a year or two when our efforts at manuring the usually less fertile land are about to benefit us. Additionally, considering our inheritance system, even we women obviously prefer that our sons should inherit our lands but not our daughters. Our landed properties are safer with our sons than our daughters under our patrilineal system of inheritance."

The landowner elders also shared thus as presented by one on their behalf: "We the elders want the new model and legislation to pay attention first to the customary system of resolving land rights disagreements and handling other land tenure issues. We like sometimes, to continue to employ sparingly though, the traditional (sacrifice and libation) mechanisms of determining rightful claimants to lands. For now, we cannot do that because national laws prohibit us and claim our practices cannot be proven by law. It may be true from legal perspective but for us, customary practices are effective for instilling discipline and compliance at all times among all community members." Then another elder added that, "any land tenure insecurity concern should first be referred to us (elders) to get our inputs to resolve or approve before parties can take them to other levels for resolution if we cannot resolve them."

One landowner (elder) from Piina further proposed the following:

"We also propose to abolish the perpetual duration of farming rights to secondary rights holders (migrants/settlers) in the new model and we support the enactment of an overriding legislation. This overarching law in the new model should stipulate shorter tenure durations (4-5 years) for food crop farming and longer durations for tree crop farming of 6-10 years. Thereafter, these arrangements will be due for re-negotiation and therefore subject to changes in the land rights, tenure, farm size etc."

Adding to the above, another landowner elder from sing continued, "we landowners will not completely eject settlers dwelling on our land, but as lands 
become scarcer, we will allow them the right to "own" some reserved parcels. The sizes will range from about 0.5 in urban to two hectares in rural areas respectively. Then landowners will still reserve the reversionary interest i.e. the right to take back the land only when it has been abandoned. Or when it is without an heir, continuously for five years without a word from the designated "settler-owner". "Furthermore," continued a third landowner elder from Nimoro, "we can engage in sharecropping arrangements with settlers instead of the current system that landowners rarely benefit from. We are comfortable with our customary system and support its operation alongside the formal system. The formal system will encourage documentation of all new and re-negotiated tenure agreements as well as allowing the courts to help resolve complex land rights or ownership challenges between communities, among landowners or between settlers and their landowners."

\subsubsection{Adapting from other models}

On the idea of adapting from other models to improve upon their current land rights and tenure model, the participants made their final suggestions after examining other models (Capaldo et al., 2010; U. E. Chigbu \& Klaus, 2013; Lovendal \& Knowles, 2006; Mulolwa, 2002). All suggestions or user requirements for a new model (responsible and fit-for-purpose) center on legal, technological, administrative, financial, socio-cultural and livelihood issues particularly food security. All of the above themes have been factored into the new model designed to promote land rights and secure tenure for the main purpose of promoting farming and food security. One landowner elder expressed the following, reflecting the opinions of other local landowners in study area:

"We (landowners) prefer a compulsion to use Alternative Disputes Resolution (ADR) mechanisms to handle/resolve our land rights and tenure issues/challenges." "After that", a second elder continued, "if there is the need, we will let the contending parties then proceed to court for compulsory and final adjudication." The earlier speaker interjected and continued, "we think it is bad for people to skip the traditional process as the first point for addressing land rights and tenure issues." Another also interjected, "we will like the new model and legislation to capture explicit benefit packages for both landowners and settlers. Just like the Akan system of sharecropping in southern Ghana, so that settlers will not always complain of poor yields for non-payment of even the token gift dues us according to custom." He continued that, "of course we also support compulsory documentation of all land issues strictly starting from our Customary Lands Secretariats (CLSs). We want government's commitment to our plight through sensitisation, monitoring and speedy adjudication. We also want flexible/alternative payment methods with cash, animals, labour or farm produce. We want the inclusion of land based/human rights legal institutions and persons like solicitors [also referred to as paralegals in Ghana] to play active roles by helping victims of land rights violations, e.g. by 
explaining the legal implications of people's actions and inactions to them in the new model." Another elder added that, "when it comes to compensations, landowners can agree to share proceeds from compulsory acquisition for instance, with their affected settlers." But he added again that, "the new law can indicate the ratio for sharing compensation money or other proceeds from disposing off the settlers' land, but we are not sure about 40:60 ratio for settlers and landowners as proposed in the draft lands act. But of course, if it becomes law with these proportions, we will oblige while advocating for a better deal."

\subsubsection{The new model}

The research used inputs from all stakeholders (i.e. user requirements) to design this new model in Figure 23. It is an improvement from the old model currently in use in the study area and which is giving the challenges presented earlier. The solutions proposed in the new model include enacting an overriding/overarching legislation for strict adherence to the existing customary processes and formal procedures for strengthening land rights and securing tenure with the court as last resort. In addition, the overriding legislation is to mandate local, formal and social media (institutional control) to highlight issues of tenure insecurity especially land rights violations periodically. Moreover, they support a legal option for those who may require the formal court system (control, enforcement \& use) after customary proceedings to do so. The overriding legislation with the new model is expected to create room for the financially weak to seek inexpensive or free legal assistance from otherwise dormant state legal and quasi-legal bodies. This, the people said is important because albeit criticised, the court system in Ghana remains the final arbiter over the customary system in all cases. Some of these currently "dormant" institutions include the Commission on Human Rights and Administrative Justice (CHRAJ), Legal Aid Board (LAB) and Alternative Disputes Resolution (ADR) units in Ghana. This legal backing is to facilitate setting up of outpost offices from the community to the national levels. They are to execute specific land tenure related tasks with little or no additional costs to the state and individuals concerned. When this takes place participants believe, the problems of weak land rights, tenure insecurity and consequently food insecurity can be resolved. In addition, payments of fines, fees, charges etc. for offences or for land use, can now include non-monetary options as an additional alternative to the cash option being used now. The overriding legislation in the new model is to allow commensurate measure of farm produce, labour supply or animals for those who prefer that option. The diagrammatic representation of the holistic (new land rights, land tenure security and food security) model is contained in Figure 23, referred to as responsible and fit-for-purpose. 
One chief (and also Nimoro tortina) remarked that the ineffectiveness of the current model became evident in overwhelmed courts in Ghana that are still inundated with land related cases. The people contend that the current ineffective model is evidenced by undermined customs in trying to resolve land rights and tenure challenges. This research also gathered from the people that the lack of a compelling legislation coupled with less sensitisation were some of the main contributory factors to weakening land rights, tenure insecurity, landlessness, ineffective farming and food insecurity in the area. Other factors for the mal-functioning of the current land rights and tenure model include no or poor legal representation due to expensive charges in mainly cash form. The solutions to all these challenges have therefore been included in the new holistic land rights and tenure model in Figure 23 below, most likely fit-forpurpose based on current need, circumstances and spatial setting. The working of the new model is explained below.

\subsubsection{How the new fit-for-purpose model will operate}

The operation of the model starts thus: enact an overarching legislation encompassing the existing customary and formal processes for resolving land rights and tenure challenges. As part of the legislation, the media (very influential in Ghana) will be empowered by the Right to Information (RtI) Act of parliament to institutionalise reporting on land rights issues especially violations as their social responsibility. The "fear" (in Ghana) for media exposure will most likely ensure compliance from all and reduce abuses. Where violations still occur, victims will freely first go through the customary process with a caveat to avoid customary authorities sitting on cases involving themselves as parties. Also, the legislation is to spell out the avoidance of "forum shopping" so that losing parties cannot unnecessarily prolong the justice process by constantly rejecting outcomes beyond three different levels of authority. Whenever the customary process fails, ends inconclusively or without satisfaction, the parties may proceed to the formal mediation and to the courts. As they follow the process, the local and formal media are legally bound to report on the processes and outcomes as well as next line of action. In going to court, legal advocates in paralegal state institutions have the legal responsibility to assist (for free or low charges) those without the needed finances to hire their own lawyers. The overarching legislation further directs that where fines are involved, people have an additional avenue to pay in nonmonetary forms besides the current cash option. 


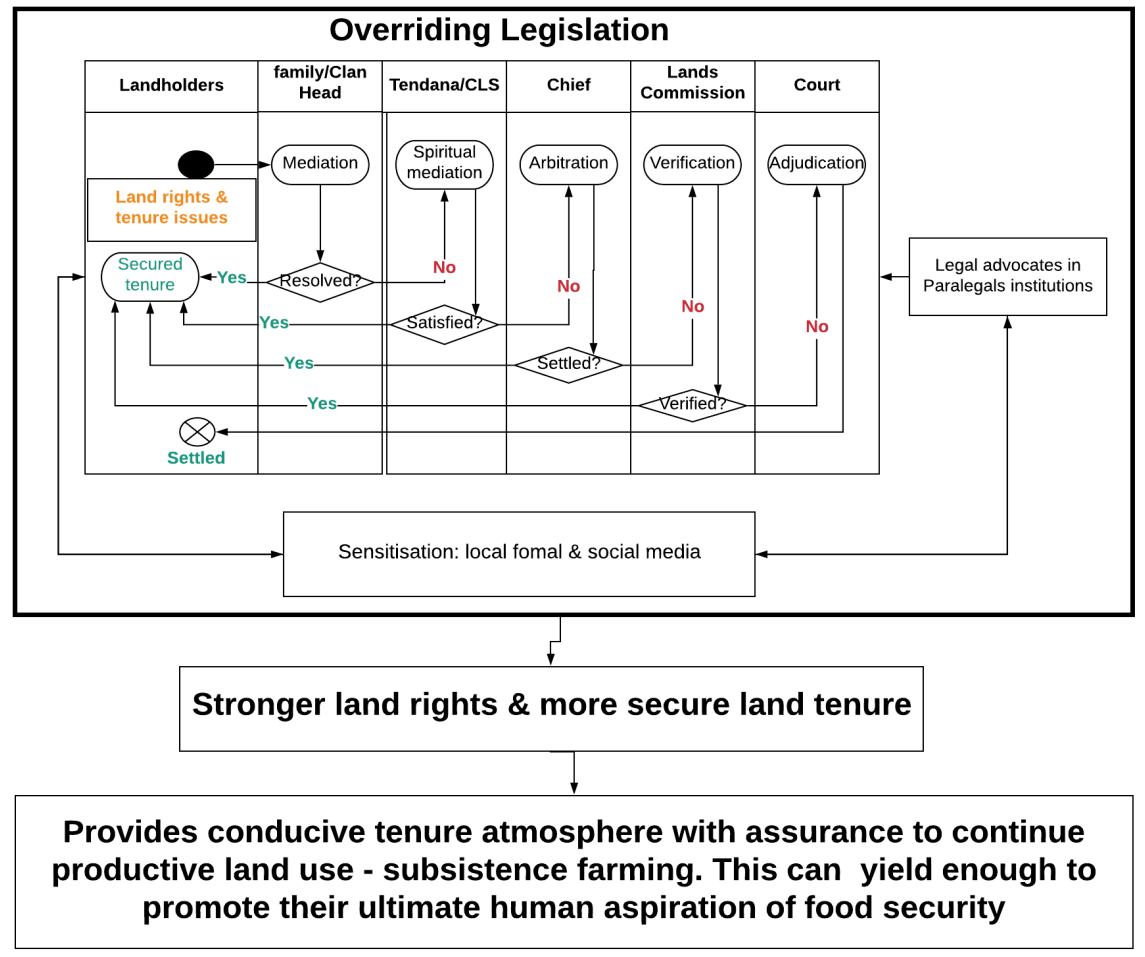

Figure 23 Responsible \& fit-for-purpose land rights \& land tenure model. (Author's construct, 2020)

\subsection{Discussion of results}

This discussion is an evidence-based interpretation of the empirical findings highlighting how this research may contribute to new ways of ensuring customary land rights and tenure security. It may also contribute new knowledge in the debate on how land rights can create conditions for increased land-based production e.g. farming, leading to food security.

What may be missing in the literature is how an overarching legislation that mandates active media sensitisation (or influences) can compel a society including the courts, to comply with a new model or law. The implication of this legal drift, as results portray, may drive increased compliance attitudes towards the new model. It is then likely to enhance dispute resolution, strengthen land rights, secure land tenure and promote food security through a conducive tenure environment for farming (Holden \& Ghebru, 2016). The new model is designed such that the overarching legislation seeks to empower already existing but probably under-utilised government/state institutions to 
implement and enforce land rights and tenure issues (Boudreaux \& Sacks, 2009; Swensson \& Tartanac, 2020). For the sake of the poor, the model ensures socio-culturally affordable payments based on the assertion by Zevenbergen et al., (2013) that affordability by poor people of land has to be prioritized. A well-functioning model is said to thrive on awareness and acceptance (Bugri, 2010). While information alone is insufficient Ballard et al., (2013), it can be a powerful tool in conscientising people to appreciate and tackle their challenges. Following the passage of the Right to Information Act as law in Ghana, Ghanaian journalists more freely perceive themselves as nation builders, agents of empowerment and watchdogs with the aim of providing information that influences policy, attitudes and action in promoting democracy. Interviewees, thought that Ghana has a free and powerful media, "possibly even too free" (Nyarko, 2015; Sumbu, Handledare, \& Stigbrand, 2013). Where institutional, administrative and managerial measures have been put in place to secure tenure, it becomes an incentive for increased investment in farming and food production (Nguyen et al., 2016; United States Agency for International Development (USAID), 2016). The United States Agency for International Development (USAID), (2016) further indicated that "where tenure was insecure, there was low farm investment and that security of women's land rights increased their agricultural investment and production as well as improved nutrition outcomes." The result of adopting this new model will likely strengthen land rights, secure tenure and promote their main livelihood activity which is farming by smallholder (settler/migrant) households to ease food security through availability and accessibility (Maxwell \& Wiebe, 1999; Nguyen et al., 2016). This has the additional potential to reduce current distribution challenges that FAO is still grappling with as noted earlier in this document (FAO, IFAD, UNICEF, WFP, 2018). Concerning the media sensitisation, the Ministry of communication will be responsible for overseeing all related activities. On issues of funding, the exercise will be regarded as the media's corporate social responsibility whiles other corporate bodies will be encouraged to support through donations in cash, training or equipment. Adverts or jingles may be aired several times a day including special slots for discussions and field reports about compliances, violations, compromises etc. All available kinds of media - mainstream, customary and social, need to be involved at different levels and locations. This is important because Ghanaians generally have widespread access to these different categories of media. This media inclusion has not necessarily been tried elsewhere as such but its potential success in Ghana is evident from similar campaigns regarding the redenomination of the Ghana cedi in 2007, the fight against illegal small-scale (galamsey) mining in 2017 and campaign to create awareness about covid-19 pandemic in 2020. In all these campaigns, there have been a feeling of widespread successes among the populace in terms of significant awareness created, acceptance and compliance by the masses as well as those in authority. 


\subsubsection{Choosing an appropriate model}

In sub-Saharan Africa, outcomes of interventions for strengthening land rights and securing tenure in the past have not been sufficiently satisfactory (Mulolwa, 2002). As a result, those past interventions could not provide the expected strong land rights and tenure security. It is especially so for vulnerable and marginalised groups of smallholder farmers who did not have the needed assurance effect on farming investment to produce more for food security (Alemie, Zevenbergen, \& Bennett, 2015; Nguyen et al., 2016). Even Rwanda and Namibia have only been able to achieve minimal successes in redistributive land reforms in their respective countries (Fosudo, 2014; Tapia, 2004). For instance, Rwanda may have successfully demarcated, surveyed, allocated and registered nearly all its lands yet it may not have achieved complete tenure security (Fosudo, 2014; Mizero, Karangwa, Burny, Michel, \& Lebailly, 2018). The above notwithstanding, it gives an indication of some possible successes if countries intensify and adopt the right strategies, models, attitudes, legislations and commitment among other things. It is equally imperative to recognise that earlier research shows that the current approach of documenting land to secure it is deemed too expensive for the poor (Zevenbergen et al., 2013). And implementation of western-based models to secure land tenure in sub-Saharan Africa yielded minimal results (Lawry et al., 2014; Mulolwa, 2002). It is therefore appropriate to adapt from the various scenarios and implementation experiences mentioned above, to get a responsible and fit-for-purpose model that suits the context and meets the requirements of the people in the study area.

\subsubsection{User requirements for designing a land rights/tenure model}

In order to answer the question on what inputs are required for an effective, responsible and fit-for-purpose (FFP) land rights and tenure model, it is important to understand the FFP concept. The FFP concept is about applying the spatial, legal and institutional methodologies that are most fit for the purpose of providing secure tenure for all by addressing the current constraints and allowing for incremental improvement over time (Enemark, 2017; Enemark \& Mclaren, 2017). Enemark's assertion guided the collation of user requirements and literature materials to design the land rights and tenure model in this research. Local norms and practices as well as national laws/courts system, all in the spatial context of Ghana informed participant's expression of requirements for a more responsible model. The local land rights and tenure institutions have been reiterated as fundamental components of their desired model (Cotula \& Neves, 2007; Mulolwa, 2002). Hence, all participants emphasised (except youth/middle-aged who simply accept) the inclusion of customary practices together with legal court system to effectively secure tenure and strengthen land rights. 
Various categories of respondents suggested inclusion of protection measures important to them. For instance, settlers suggested a compulsion by law for documenting all land rights and tenure agreements with the new model in place. Women also suggested at least five years of non-interference by landowners after which a renegotiation has to take place to determine if any changes can occur in the existing land rights that women currently hold. On the part of the disabled, they suggested that stiffer sanctions be given to people who trample on land rights of the physically challenged. All these are included in the overriding legislation and new model. This model therefore, places some emphasis on protection of people's land rights by higher authority: government, courts and customary institutions and therefore agrees with other scholars (Almeida \& Wassel, 2016; Boudreaux \& Sacks, 2009; FAO et al., 2015; Quan \& Toulmin, 2004; Toulmin, 2008). The model also stresses on the important role of information as a powerful tool in conscientising people i.e. for sensitisation and awareness creation on issues of land rights and tenure security particularly on violations (Ballard et al., 2013). Bugri (2010) raised what this research found to be critical for strengthening land rights and securing tenure, which is that local customary methods of sensitisation are equally indispensable. In addition to mainstream and local media, is a careful utilisation of social media to quicken information sharing. However, social media option is to provide initial information that will be subject to verification before any actions are taken.

The land rights and tenure security model in this research recognises the need to support the poor, vulnerable and marginalised groups at affordable costs, to access justice in the form of strong land rights and secure tenure (Christine et al., 2015). Therefore, the model in this research includes the use of paralegal institutions in Ghana whose inclusion will have little or zero cost to the poor when seeking land rights and tenure justice.

\subsubsection{Adapting from other models}

The current land rights and tenure model is ineffective and the local people desire a more effective and efficient one which they find capable of encouraging more farming investments, food availability and food security (Nguyen, 2014; Nguyen et al., 2016). Another assertion by Lengoiboni et al., (2019) is that community driven endeavor or initiative is vital to address specific needs. It has played a pivotal role in adapting and designing a final model towards strengthening land rights and securing tenure in northern Ghana in this research. There were other useful hints to an appropriate land tenure and food security model to be fit-for-purpose (Lovendal \& Knowles, 2006; Mulolwa, 2002). Mulolwa for instance, advocates adapting other models to fit the local context by admonishing that some aspects be infused into existing local models that the people are already familiar with and can easily cope with. Mulolwa therefore, discourages wholesale adoption of unfamiliar models, which 
corresponds with the findings of this research and concludes that such unfamiliarity is partly the reason for the failure of land rights and tenure interventions in many sub-Saharan African countries in the past. Other scholars, Capaldo et al., (2010) identified "risk management actors" representing the regulatory power by various institutions and the "risk type" i.e. the tenure insecurity being crucial factors to assess vulnerability to food security. Risk, in the context of this research refers to weak land rights and insecure land tenure. This research identifies with Capaldo et al., (2010) that to strengthen land rights and secure tenure to lead to food security, customary and government institutions must play key roles. Besides these, other NGOs, CBOs and chieftaincy institutions can be valuable to help resolve tenure challenges if local people themselves invite these bodies to intervene.

\subsection{Conclusion and policy recommendations}

This paper aimed to design a responsible and fit-for-purpose land rights and tenure model for strengthening land rights, promoting farming and ensuring food security. To do this, it collated user requirements through a number of qualitative research approaches. Data collection process used FGDs, key informant interviews, workshops and community forums. This research results show there is an existing land rights and tenure model with insufficient legal backing and weakened customary authority to enforce it thereby, making it ineffective in strengthening land rights and securing tenure. As a result, the people rarely use it and this has compounded their tenure challenges consequently affecting farming and food security largely in terms of food availability. The less food availability therefore translates to weak food accessibility, poor nutrition and poor food stability in the area.

A responsible and fit-for-purpose land rights and tenure model was designed, directly reflecting protection measures important to different categories of people. Thus, while settlers suggested documentation, overriding legislation and sensitisation, women emphasised a five-year moratorium (grace period). The disabled suggested stiffer punishment against abusing those with disability. All these included in an overriding legislation makes the current model potentially more effective and efficient if there is sustained sensitisation and paralegal/legal advocate support. This is what the communities aspire to and consider to hold the prospects that can facilitate stronger land rights and secure land tenure for their land-based livelihood activities particularly farming. For instance, the anticipated investments in time, money and effort on farming can make more food available i.e. food availability, for food security. It is the conviction from this research and based on literature that more food availability from farm investments as stated above, then creates an avenue for subsistence farmers to sell some of their excess farm produce to access other food varieties (i.e. food accessibility). Given the above analogy, then all four food security dimensions can be achieved directly or indirectly. 
This is because, as food supply is also continuously available and containing the right nutrients, food nutrition and food stability can be achieved too.

This research concludes that the model can be effective and functional but subject to testing in further research. It can also be beneficial to other jurisdictions even though some aspects of the theory need to be adjusted to suit the specific local socio-cultural contexts within and outside of Ghana. The concept of overriding legislation and legally mandating sustained media campaign purposely towards strengthening land rights have not been tried anywhere from the literature so far. However, Landesa is quite successful in using legal advocates and other paralegals to support vulnerable and marginalised women and men to secure land tenure and strengthen land rights among others in India, some parts of Ghana and other countries in the world. COLANDEF-Ghana also empowers smallholder land users, women, migrants and other disadvantaged groups at the local level through advocacy and education on land rights. It also carries out capacity building for customary land authorities and uses experiences at the local level to inform policy discussions. These efforts have yielded some significant outcomes albeit much more remains to be achieved. Thus, the combination of various organisations' efforts has inspired this fit-for-purpose land rights and tenure model. This FFP model then promises to help realise a synergy of the combined separate efforts towards stronger land rights and more secure land tenure into the future. This research, through the FFP model, offers an additional flexible (non-monetary) payment option to settle fines and rents by local people apart from the cash option that until now remains the only general payment mode at the end of customary or court dispute settlement about land tenure in Ghana.

In sum, it might be worthy to re-emphasise that legislation and legal enforcement, media involvement and awareness creation, co-creation, flexibility and alternative payment terms, use of legal advocates, affordability, re-negotiation terms etc. make the new FFP model different and better than the old model, to say the least. 


\section{Chapter 6 Testing a fit-for-purpose (FFP) model for strengthening customary land rights and tenure to improve food security in northwest Ghana}




\subsection{Introduction}

Land is a fundamental source of livelihood for most people in the world. It contains various rights that people can lay claim to, through inheritance, purchase or other means. In other words, these land rights are the entitlements and practices that communities use to make land available to various categories of users and uses. Some people, the landowners usually hold primary and strong land rights while others e.g. settlers generally hold weaker secondary rights (John Tiah Bugri, 2010; Nara et al., 2020a). Those who possess weak land rights tend to produce insufficient food from their farms and are consequently more prone to experiencing food insecurity (B. Baslyd Nara et al., 2020a; Peters, 2013b). Meanwhile, food security of many subsistence farmers especially in sub-Saharan Africa, Asia and southern America largely depend directly on strong land rights and secure tenure (Bugri, 2010; Cotula \& Neves, 2007; Nara et al., 2020a). This probably explains why the UN explicitly captured food security in its Sustainable Development Goals (SDGs) 1 \& 2. Additionally in sub-Saharan Africa, where there is low application of agricultural mechanisation coupled with land rights and tenure challenges, many farmers still require large amounts of land to produce sufficient food (German Federal Ministry of Food and Agriculture (BMLE), 2015; Ruerd, 2011). Meanwhile, weak customary land rights and insecure tenure issues of marginalised subsistence farmers characterise many land dealings in these areas (Cotula \& Neves, 2007).

\subsubsection{Debates surrounding use of models for securing tenure}

There are many debates surrounding the usefulness of models for securing land tenure, promoting land-based production like farming and securing food. Such models are usually tailored towards dealing with specific tenure issues and in particular contexts. One of such models is the vulnerability to food insecurity model (Capaldo, Karfakis, Knowles, \& Smulders 2010). This model establishes the relationship between assets like land i.e. ownership and its influence on vulnerability to food insecurity due to shocks that affect agricultural production. The model asserts that there can be chronic food insecurity associated with land "ownership" and those earning income from onfarm activities. The suggestion then is that farming can expose households to food insecurity shocks with lasting negative consequences if the right tenure strategies for instance, are not adopted. Accordingly, models seek to facilitate an assessment of a problem and provide the framework for dealing with them holistically (Nara, Lengoiboni, \& Zevenbergen, 2020b). The model by Capaldo et al (2010) allows for an analysis of how vulnerability relates with various household characteristics, in order to profile the most vulnerable households and to draw conclusions on possible causes of vulnerability to food security. This model also engages in poverty analysis based on various unspecified risk factors to analyse food security. However, this paper tested (in a role-play 
session) the new responsible and fit-for-purpose land rights and tenure model (in short: FFP model). To validate its possible success when implemented based on a specific risk factor i.e. weak land rights and insecure tenure of the end users. Hence, Capaldo et al (2010) is based on the social risk management approach where previously unknown factors are risks of different kinds. Therefore, households' risk management abilities of these uncertainties like weak land rights and insecure land tenure issues determine the future food (in)security status. Their model explains how current characteristics, risks and risk management capacities affect the likelihood of a favourable (or unfavourable) future food security status.

A second model assessed in this work is a land tenure model (Mulolwa, 2002). This model examines land tenure and land reforms in a few sub-Saharan African countries. The analysis reveals the reasons for reforms and the resulting insecure land tenure in the sub-region. Given this nature of tenure challenges in sub-Saharan Africa and the arguments for or against, the case is then made for an alternative model (Mulolwa, 2002). The argument is further made as to whether customary tenure in its current form and practices is or not an obstacle to stronger land rights and tenure security. Mulolwa subsequently recommended a kind of a model, believed to be effective in particular contexts to promote land rights, land tenure security and consequent productive use of land for example for farming. The result of Mulolwa's recommendation is expected to lead to attainment of human aspirations, following strong land rights and secure tenure, which can lead to improved food production, food availability and food security.

Another model by Chigbu \& Klaus (2013), analyses land rights and tenure influencing food security as a consequence. This model shows how land tenure practices can lead to either food security or insecurity. They further argued that a secured land tenure system, guided by a model, would generally lead to well defined and sustainable ownership structures, uses and management of resources. Chigbu \& Klaus (2013) therefore contend that such a structure or model encourages defined property rights that lead to efficient land-based innovation and production systems. And this includes farming, devoid of unnecessary land rights and land tenure disagreements, the result of which can be increased food production, food availability and food security.

This research inspired by all three models, taps especially into that of Chigbu \& Klaus (2013) as that directly connects land tenure to food security. This research aims at testing (i.e. validating) the effectiveness of a responsible and fit-for-purpose land rights and land tenure model for this customary context in northwest Ghana. And examines its influence on food security of subsistence farmers, particularly non-landowners (migrants/settlers). According to Enemark \& Mclaren (2017) a fit-for-purpose land administration system must 
be flexible, participatory and inclusive - locally engineered. Detail discussions on FFP model are contained in a paper preceding this one and submitted to Land MDPI journal - special issue for publication. This local involvement is what Galvagno \& Dalli (2014); Ind \& Coates (2013) referred to as co-creation. In this way, the model is potentially effective and successful, which Enemark and Mclaren describe as reliable, attainable and upgradable into the future. Thus, a requirement of fit-for-purpose system is to use the community to describe the tenure system and the kinds of evidence of the land rights currently in use (Zevenbergen et al., 2013). The model is then mock-tested within the sociocultural, political and economic environment where it will operate. Of course, based on communities' inputs and best practices of the effectiveness, functioning and possible obstructions to the model to address community land rights and tenure issues.

\subsubsection{Effectiveness of the models}

The FFP model in this paper targets the vulnerable and marginalised subsistence farmers in local communities. The effectiveness of this model is therefore measured based on its anticipated feasibility to assist these farmers access relatively strong land rights and obtain more secure tenure to boost local investments in farming for food to sustain their households (Nguyen et al., 2016; Zevenbergen et al., 2013). Referring to responsible and fit-forpurpose land administration and management; Enemark, Bell, Lemmen \& McLaren (2014) believe such a model must be addressing the current constraints and allowing for incremental improvement over time to be regarded as effective.

\subsubsection{Functioning of the models}

In testing the functioning of the model, each participant (as an individual or in a group) engages in role-plays by dramatizing specific roles in the model as a trial of how it will function in practice. The available literature suggests that isolated implementation of either the current old or adopted model used elsewhere, cannot effectively promote strong land rights and secure tenure (Mulolwa, 2002). Rather a careful combination of various customary and formal land tenure practices, institutions and laws according to Mulolwa (2002), in addition to a strong attitudinal change is key. The stakeholders must also be desirous of success and committed to the proper functioning of the new model to ensure that it functions well, it is effective and efficient (Asperen \& Mulolwa, 2006; de Vries \& Chigbu, 2017; Mulolwa, 2002).

\subsection{Obstructions to the effectiveness of models}

The review of the above models gives a clear indication that the effectiveness of models can be obstructed by a number of factors and in various ways. Capaldo et al., (2010) believe that vulnerability is the result of a recursive 
process. That is, current socio-economic characteristics and exposure to risks determine households' future characteristics and their risk-management capacity. The risk management strategies mentioned by Capaldo et al., (2010) invariably include how local land rights and tenure issues are being managed to make land available to people to farm and produce food for enhanced food security. A model can therefore facilitate and improve policy design and targeting. It implies that inappropriate management of risks like land rights and tenure issues, can obstruct the success of their model.

Asperen \& Mulolwa (2006) asserts that model effectiveness can be obstructed if dynamism in social land tenure relations are not upheld. The dynamism makes the model upgradable and allowing for incremental improvement (Enemark et al., 2014). This is because a model must be aimed to support individual, concurrent and communal rights. In which case emphasis may have to shift from ownership of land alone but to include rights to use land resources. Local tenure experiences have been mentioned also to be important but more so for tenure instruments/rules in the form of a model. For Mulolwa, rights and obligations as well as commitment and attitudinal change are necessarily captured in an effective model without which its effectiveness can be obstructed.

Chigbu \& Klaus (2013) also insist that land tenure practices can lead to either food security or food insecurity. For a land rights and tenure model to be effective, there is the need for good land policies that focus on fair laws that consider the interests of the poor. They, Chigbu \& Klaus (2013) believe that achieving this effectiveness cannot be feasible without the participation of rural people in the land rights and tenure strengthening process. Therefore, facilitating the co-creation of a model that can be said to be responsible and fit-for-purpose is fundamental (Enemark, 2017). Co-creation is the joint, collaborative, concurrent, peer-like process of producing some new object, model or value, both materially and symbolically (Galvagno \& Dalli, 2014; Ind \& Coates, 2013). Given the above perspectives, it implies that the lack of or inadequate local participation in model creation (i.e. whether co-creation or coproduction) forms an obstruction to model success and must be addressed.

The focus of this paper therefore contributes to the discussion about the use of models to address socio-cultural challenges such as strengthening customary land rights and securing tenure. Further it needs to pay attention to the possible obstructions to the effectiveness of such models towards the realization of human aspirations like farming and food security.

\subsubsection{Land and farming arrangements in the study area}

The study area is located in the northwestern corner of Ghana as shown in Figure 3. In terms of land rights in the study area, the land rights are derived 
from the type of interest or title available to clans or families in the study area as briefly described below in Da Rocha and Lodoh (1999).

1) The allodial title: is the highest interest in land which is communally owned by clans or families.

2) The customary freehold interest: is family land use rights held perpetually as members of the allodial title.

3) The common law freehold right: is acquired by individuals or groups (usually outside the landowning group) through express grant from the allodial owner or customary freeholder. It is either in the form of sale, gift or other arrangements. It is usually held in perpetuity.

4) The 'leasehold' right: is acquired by individuals or groups also usually from outside the landowning group. It is given through express grant from the allodial owner, customary or common law freeholder in the form of sale and is subject to periodic renewal with the grantor based on the terms of the agreement usually 99 years.

5) Customary tenancies: are largely farming rights that landowners usually make available to non-landowners like settlers/migrants. The land rights of settler subsistence/smallholder farmers are derived from the customary freehold interest from landowning families, clans and sometimes individuals.

Generally, the farming arrangement in the study area and the rest of northern Ghana is a customary cropping (but not share cropping) agreement in which the land is given out 'free' to settler/migrant farmers who are usually nonmembers of the landowning group for farming on subsistence basis. It is important to note as contained in Nara et al., (2020a), that if the purpose is for large-scale commercial farming, the arrangement will be different. In return, the subsistence settler farmer provides a small portion of the yield i.e. "token gift" (estimated at a worth of seven euros or 40GHS), annually after harvest to the landowner. This gift given out is a way of affirming the mutual settler-landowner relationship. This cropping arrangement in the study area is unlike the share-cropping arrangement also known as "Abunu" or "Abusa" in southern Ghana.

The land rights model in use in the study area shows an ordered hierarchical structure in place as shown in Figure 22 . The reality however involves a complex relationship between landowners and settler farmers, among landowners and between males and females. It also involves all reference to tendana, tortina or tengansob as the custodian of all customary rights on land in the area. Besides, the land rights model here currently involves a dual system of customary and statutory/legal/formal operating concurrently. The consequence of this situation is a seeming confusion characterised by little or no adherence to the rules and a consequent breakdown of order in the land administration and management in the area. Hence, the need to redesign a 
more effective and functioning model to strengthen land rights and secure land tenure.

The normal order shown in Figure 24 has broken down currently in practice, largely due to lack of an over-riding legislation. That is, there is no compulsion to abide by the model and there are hardly any sanctions for non-compliance to the model.

Under the current scheme of things, a land issue from a landholder can be taken straight to Lands Commission or even the court instead of following the order. That is, from landholder - family or clan head - tendana - chief (when civil issues arise) - Lands Commission - court. These institutions have attempted to resolve some of these land tenure concerns but the results of such attempts have been unsatisfactory to the people. They did not strengthen land rights neither did they make land tenure more secure. This failure then emboldened the local people to participate and co-create their desired model in Figure 26.

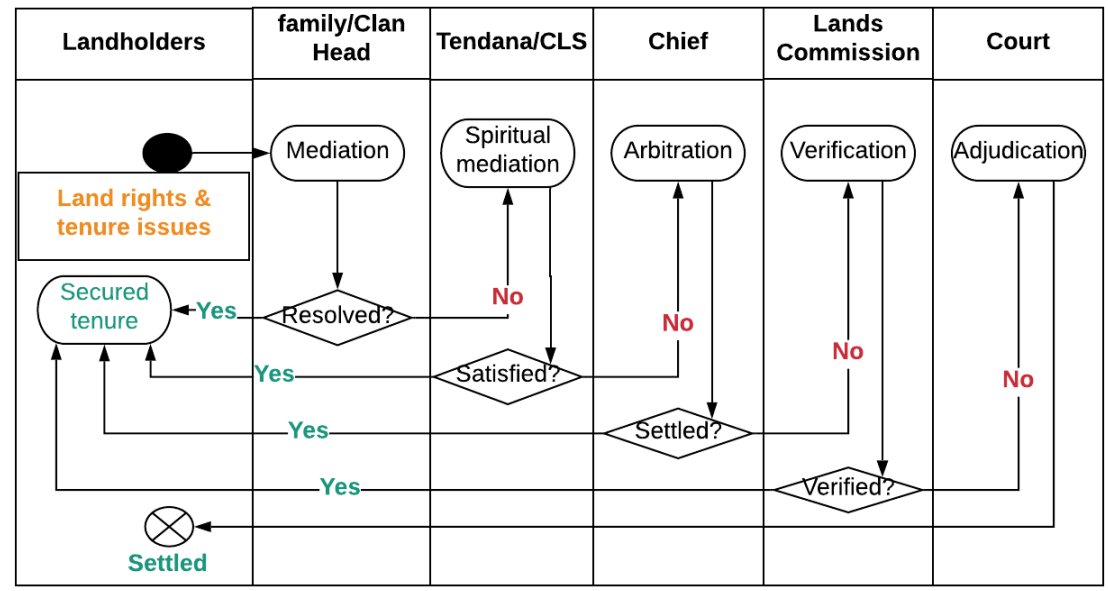

Figure 24 Current land rights \& land tenure model in study area. (Source: Nara et al., 2020b) - identical to Figures $16 \& 22$

\subsection{Methods}

This research used mainly the qualitative approach of data collection in six communities (settlements) in all, two in the Wa municipality - Sing and Kunfabiala. The other four are Piina Number One and Piina Number Two in the Lambusie-Karni district and, Nimoro and Fielmua in the Sissala west district in Figure 3. The data was collected in phases, briefly described below.

In phase 1, focus group discussions were used to solicit information from various categories of people in the community. For example, males and 
females, elders and youth, disabled and abled and, settlers and landowners. These groups responded to questions, some of which are contained in Box 1.

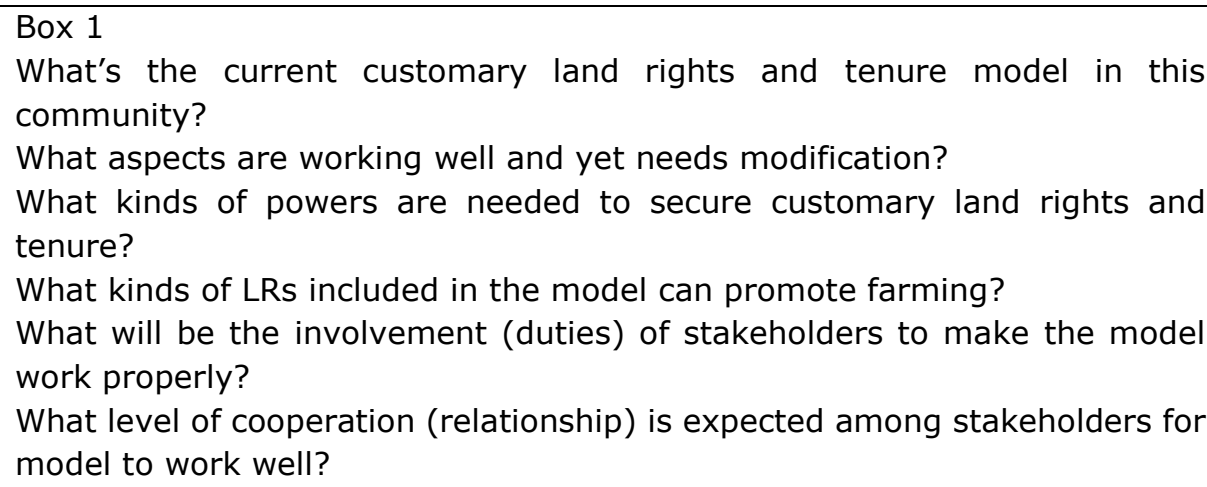

The responses received suggested the need for modification of the current land rights and tenure model to make it more effective in protecting land rights and securing tenure. The details have been presented in the results section later.

Key informant interviews that were conducted, targeted heads of landowning groups and heads of settlers as well as community level local government persons like assembly and unit committee persons. Other opinion leaders in the communities like retired influential civil servants and agricultural extension officers residing in the community were interviewed too.

Key persons in key institutions/organisations were interviewed. The first is a representative of the regional body governing lands on behalf of government i.e. the Lands Commission (LC). The second is a representative from the Wa Central Customary Lands Secretariat (WCCLSs) - an association of landowners' central office in charge of facilitating and documenting local land transactions. Furthermore, a private land documentation body, i.e. Meridia-Ghana also provided information in the institutional interviews via email through its representative.

Information from these government authorities and non-governmental organisation - merridia regarding the Land tenure and the FFP model suggests that on expiration of a tenure, the land either reverses to the landlord otherwise, the settler farmer re-negotiates it. To ensure tenure security, the stakeholders have to avoid deliberate violation of people's land rights under customary arrangements, get reliable and signed witnesses to land rights agreements, encourage documentation of tenure agreements that are sensitive to the marginalised and vulnerable. The LC and CLS asked for a shorter court adjudication period of not more than 5 years contrary to the current practice. They also called for lower cash charges, include non-cash charges as well as flexible payment terms. LC further admonished itself to 
uphold good land management practices as contained in its position on the FFP model.

In phase 2, group discussions were held with representatives of male and female groups. For instance, three disabled, three middle-aged and three elderly males formed one group for this phase of the data collection. In the same vein, three disabled, middle-aged and elderly females also formed the female group for their side of the discussion. All these discussions were aimed at fine-tuning the various issues raised in the earlier interviews and focus group discussions. Some of the topics/questions discussed during this phase include the following in Box 2.

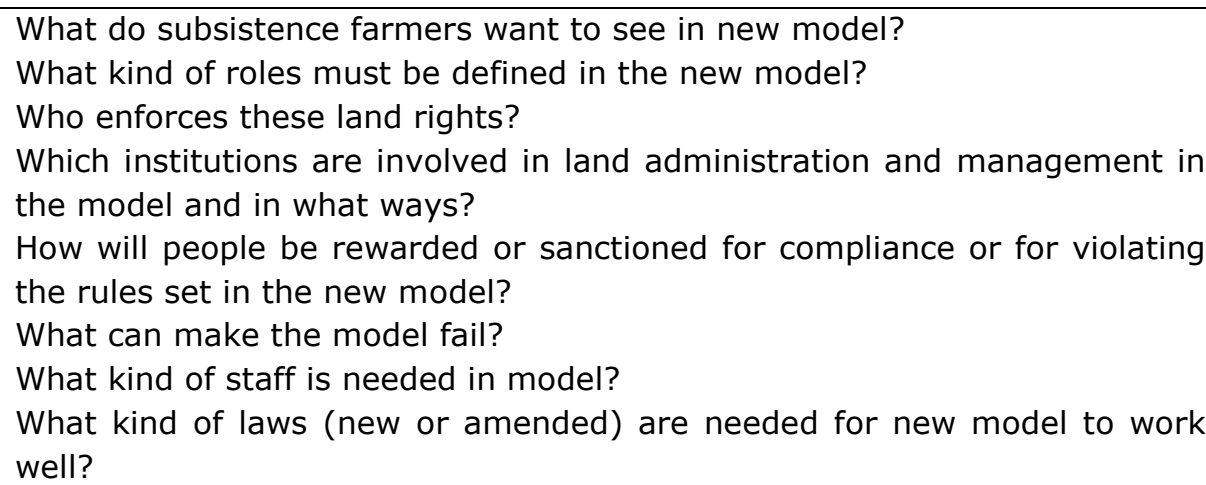

This discussion gathered responses about user requirements, role compatibility of people, institutions, laws \& stipulated periodic changes as well as strategies used elsewhere among others.

In phase 3, joint community workshops were organised for landowners and settlers from the same local jurisdiction affected by the same customary norms, laws and practices to assess the possibility for model success. The idea was to streamline seeming different assessments (i.e. expressed opinions, aspirations or understandings) of current rules and practices surrounding land dealings in order to merge them and arrive at a common united opinion/position about the model's success for stronger land rights and more secure tenure for all. The process of streamlining involved these questions/topics in Box 3. During the process of streamlining, the questions were raised and as varied opinions or suggestions were expressed, then smaller group discussions ensued. Later the representatives from the smaller groups in turns explained the reasons for their position to the rest. This generated further questions, explanations and discussions until a consensus was reached so that the common position was documented as presented in the results later. 


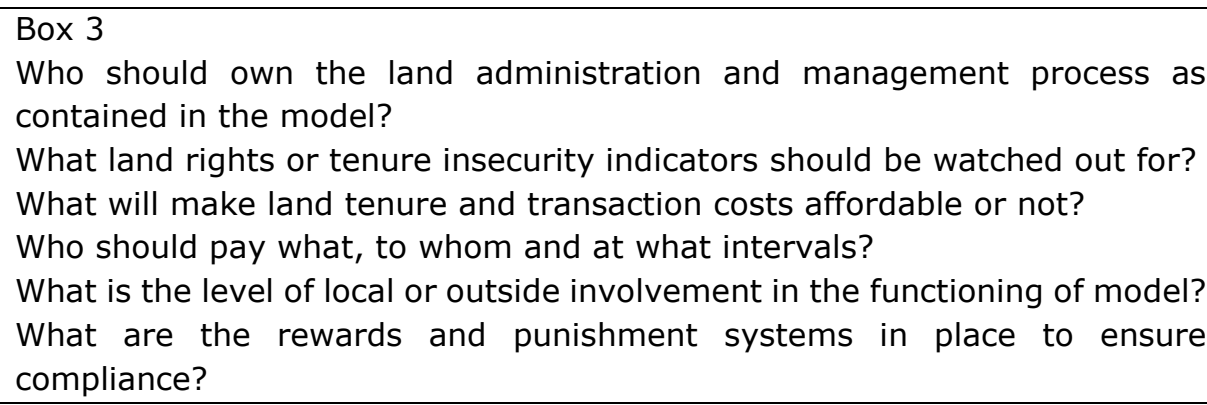

The responses generated included stakeholder roles, positions, "red-flags," responsibilities, timelines and measures to encourage compliance or deter violations.

Finally, in phase 4, separate community fora were organised to relay the outcome of the joint workshops and to receive final inputs from community members present for a final outcome representing their common position, interest, challenges and solution strategies.

The workability of this model was tested through role-play at the level of each community. Because this research is qualitative, different behavioural/attitudinal changes matter according to de Vries \& Chigbu (2017) at the testing and the actual implementation stages. Model testing is a key activity undertaken during a model design process to assess its possible success and factors that may obstruct proper functioning, effectiveness and efficiency (Tsioptsias, Tako, \& Robinson, 2016). The testing is also to crosscheck that the model is acceptable for its intended use and meets specified performance/user requirements. It is also based on comparing best practices versus real-world situations (Rykiel et al., 2011). To maintain a model's effectiveness, there is continuous need for testing, and for modelers and users to work closely together in the model implementation process to ensure its success (Tsioptsias et al., 2016).

During the FGDs and before the people rated the potential success of the model, a dummy model was shown. The dummy model had community members purport to apply the overriding legislation mandating active roles of media, legal advocates in paralegal institutions, LC, CLS/tendana, chief, family head etc. in the process aimed at trying the model's functionality and potential success. Various tenure issues - ownership, transfers, disputes and rights clarification were dramatised i.e. tested in role playing scenario by mock offices and their representatives as in the new model. The participants identified and addressed potential land rights and tenure issues by way of providing possible solutions and connecting that to how it can possibly address their food security concerns in the area. The main purpose of this exercise was to envisage the 
outcome of a participatory community generated or co-created model through consensus building. The ultimate objective was to address local land rights and tenure issues first, based on which productivity from land can be promoted. In the context of this research, it is to promote farming and secure food of marginalised and vulnerable subsistence farmers among others. It infers from the analysis of existing phenomena (land rights) policies (customary and formal practices) in order to predict how functional and successful a new model will be in a test-case using the communities themselves.

The testing was organised in the form contained in the New FFP model-testing flow chart in Figure 3. It proved to be very easy to follow, informative and practical to understand and implement. It demonstrated that the overriding legislation (OL) served as a watch over all other units within the model. It was useful to the extent that because people did not want to get in the way of the law, respondents had to comply. 


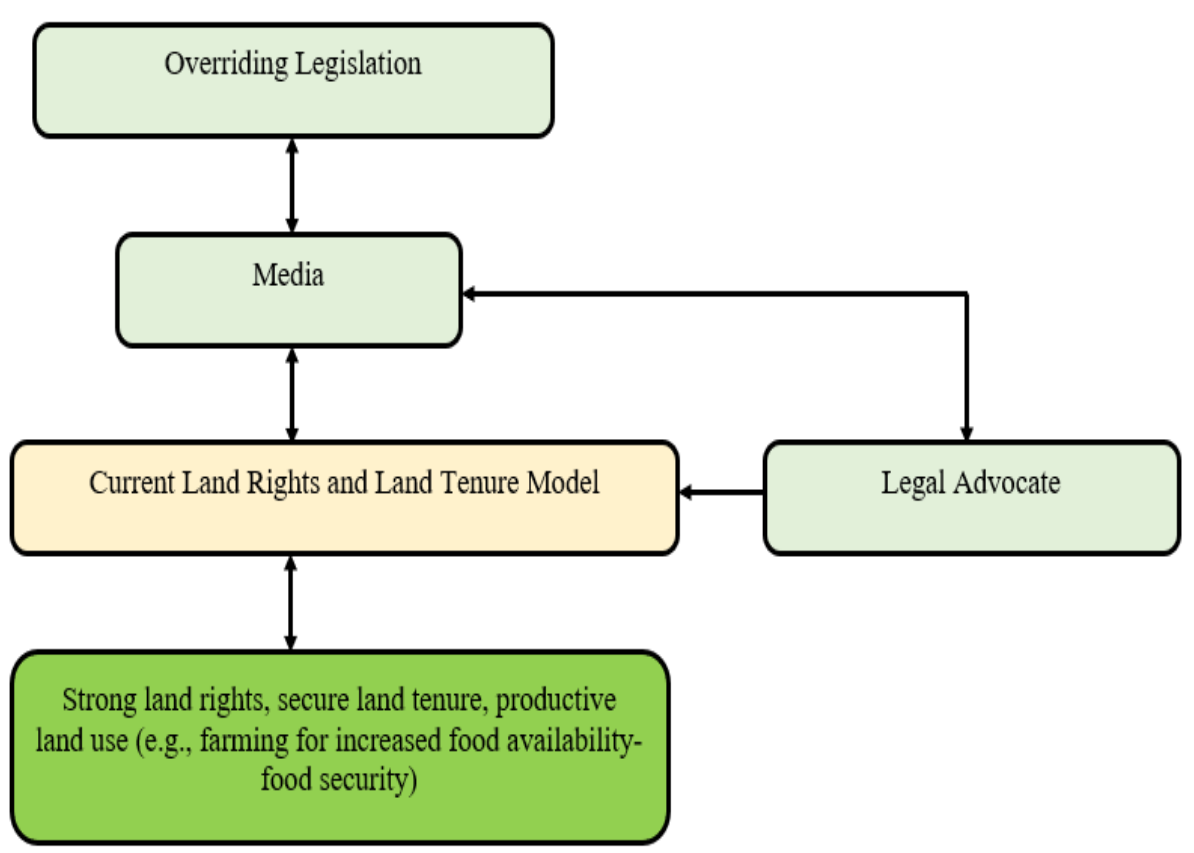

Figure 25 Model-testing flow chart Author's construct based on fieldwork, (2020)

\subsection{Findings}

This section presents some non-structural and intangible aspects of the model to ensure it succeeds. These elements include attitudinal change like willingness and commitment to patronize the new model among all stakeholders. These issues were obtained from the various groups in the study area during the data collection process. Thus, government and other institutions for example the courts, security agencies, lands Commission, media, local communities, NGOs and CBOs would need to perform their tasks assigned in the new FFP model. Furthermore, the testing process aims to scrutinise and monitor the new FFP model to identify potential interruptions that can be quickly addressed for the anticipated reliability of the model when it is implemented. These are presented under effectiveness, functionality and obstructions to the model.

\subsubsection{Effectiveness of new model}

The process to solicit the people's assessment and opinions regarding the anticipated effectiveness of the new model is contained in the methods section. The community members expressed that the new model can function efficiently and effectively when all stakeholders are committed to it when implemented. 
This was generated through a process of consensus building as also explained in the methods section where opposing views were subjected to further discussions, explanations and sometimes lobbying within the groups until the desired agreement was reached. For instance, the participants mentioned that mutual respect for one another's land rights is a pre-requisite for the effectiveness of the new model. They also advised one another to endeavour to reach compromises quickly whenever land rights and tenure challenges emerge. In addition, they indicated that they will change their attitude from indifference to one of active patronage, contrary to the past. They said their acceptance of their active involvement in the complementary customary and formal processes for resolving land related challenges can promote the FFP model's effectiveness. This they said is necessary as the dual operation of both systems is already "deeply-rooted" in Ghana and the case study communities for that matter. One common expression during the workshops and community fora voiced by one settler elder was that:

"The government, through the formal/legal system has enormous power over all our customary institutions, laws and practices. So how can we fight it? We will rather cooperate with it for our common good." Another added "However, we expect a strong commitment from all stakeholders especially landowners, to the tenets of the new FFP model. Thus, we must be seen to be giving all categories of customary people their due rights, responsibilities and benefits otherwise the model will fail."

This emphasises communities' commitment to abide by the implicit hierarchical order of resolving their land rights and tenure challenges as well as handling other land related issues that are not necessarily conflicting. They also emphasized, recognising the primacy of customary norms and practices as well as the supremacy of the government's legal system as contained in Section 13(6)(a) of the new Land Act 2020, Act 1036. In this way, they admitted that they can attain the ultimate benefits of stronger land rights and more secure tenure for farming and food security in the following expression from one landowner (male elder) in the presence and on behalf of the rest that:

"We all agree that the new model will work when we all accept that some modifications to our current model are inevitable because this approach seems to suit us and works in other countries. First, the government's lead and oversight role of the processes to strengthen land rights and secure tenure through enacting and strictly implementing an overriding legislation [partly in the Land Act 2020, Act 1036] to govern all land issues holds the key to an effective FFP model. Therefore, if government reneges on its core responsibility", "then the model will likely fail." Another elder concluded on that and continued thus "Similarly, the model will likely fail if other stakeholders (particularly we landowners) are not steadfast for its success. For instance, by the third sitting and third level of pursuing a particular case, the resolution 
must be reached to avoid unnecessary delays contrary to what pertains in our current land rights model."

The people also, expressed the workability of the new model because of its expected legal backing and strict adherence to its tenets. For instance, a spokesperson for women expressed their support for:

"Clarity of laws and roles on land rights and tenure [e.g. aspects of the Land Act 2020, Act 1036]. At least every individual or category of people will be clear on our rights, responsibilities and limitations. We will know that the current technological media space will publicise every issue emanating from land especially where an overriding legislation mandates the mainstream media to broadcast land rights and tenure issues." Another interjected thus: "the media is especially empowered, given the recent passage of the Right to Information Act in Ghana." Yet, another woman also added that "it will be easy for social media too, to quickly share any rights violations even from remote areas and immediately draw the attention of the mainstream media and legal advocates/paralegal support group to pick it up from there. We know that this will open the matter up for human rights institutions, NGOs and the state to know and get more interested and involved in safeguarding the land rights and tenure security of all but especially we [women], the weak and vulnerable in our communities. In this way, the new model will not fail as fearlessness and fairness will ultimately prevail."

The local people further expressed that their current tenure challenges have increased and become complicated. To them, it is because of youth disobedience for custom and elders due to influences of formal education, Christianity and Islam that weakened the hitherto high respect for customary processes of resolving land rights and tenure challenges. Meanwhile, these institutions were supposed to complement the efforts made by customary elders on land rights. That is why they stressed that the inclusion of an overriding legislation holds the prospects to secure tenure and strengthen land rights and make the model work effectively. This is because all will henceforth be compelled to commence with the customary institutions as contained in the new Land Act 2020, Act 1036 of Ghana. Thus, restoring reverence for useful customary practices, norms and institutions that were being disregarded. The customary system is still relevant because one elder said:

"We the elders are bequeathed with the right information based on several years of witnessing our ancestors handle similar challenges in the past. We are also in a better position than our youth and the government to know the rightful landowners or holders and associated tenure terms for each category based on these years of experience." "Furthermore", another continued "we [elders] have more sober tolerance to dutifully dispense justice, using ADR or simply supply the needed information to the courts for addressing any land rights and tenure issues/contestations with the use of the force of the laws. 
This will ultimately bind parties to its ruling." Yet another continued that "introducing the idea of renegotiation and documentation will make the model succeed because it will facilitate reference to past judgments and agreements. It will also create room for parties to correct any oversights in already concluded agreements." Also, a fourth elder contributing to the discussion opined that "the inclusion of the idea of obligatory fines for non-compliance and flexible, non-monetary payment options will all facilitate the feasibility of this new FFP model to not fail."

Invariably they emphasised that where there is no compulsion to abide by the new model in a law, weak application of the laws on it or indifference to it will likely make it fail. On the other hand, with increased and sustained sensitisation, penalty for non-compliance and avenues to use flexible payment options, the model will most likely succeed.

\subsubsection{Functioning of the new model}

The FGD participants support an ordered hierarchical structure of the FFP model (in Figure 24). The participants contend that the land rights and tenure process must exhaust the local avenues in Figure 24, of resolving land issues (contained in Ghana's Land Act 2020, Act 1036). According to them, it may also involve NGOs at various levels if they are invited. The final stages may then be the verification of documentation on agreements by Lands Commission (LC) and adjudication by the courts as a last resort. They believe that this FFP model can function properly and can lead to some of their desired aspirations of strengthening land rights and securing land tenure if they all commit to it. And this may translate to the realization of their ultimate outcome (as farmers) of facilitating farming, increasing food production and food availability, which may enable them to attain some level of food security. 


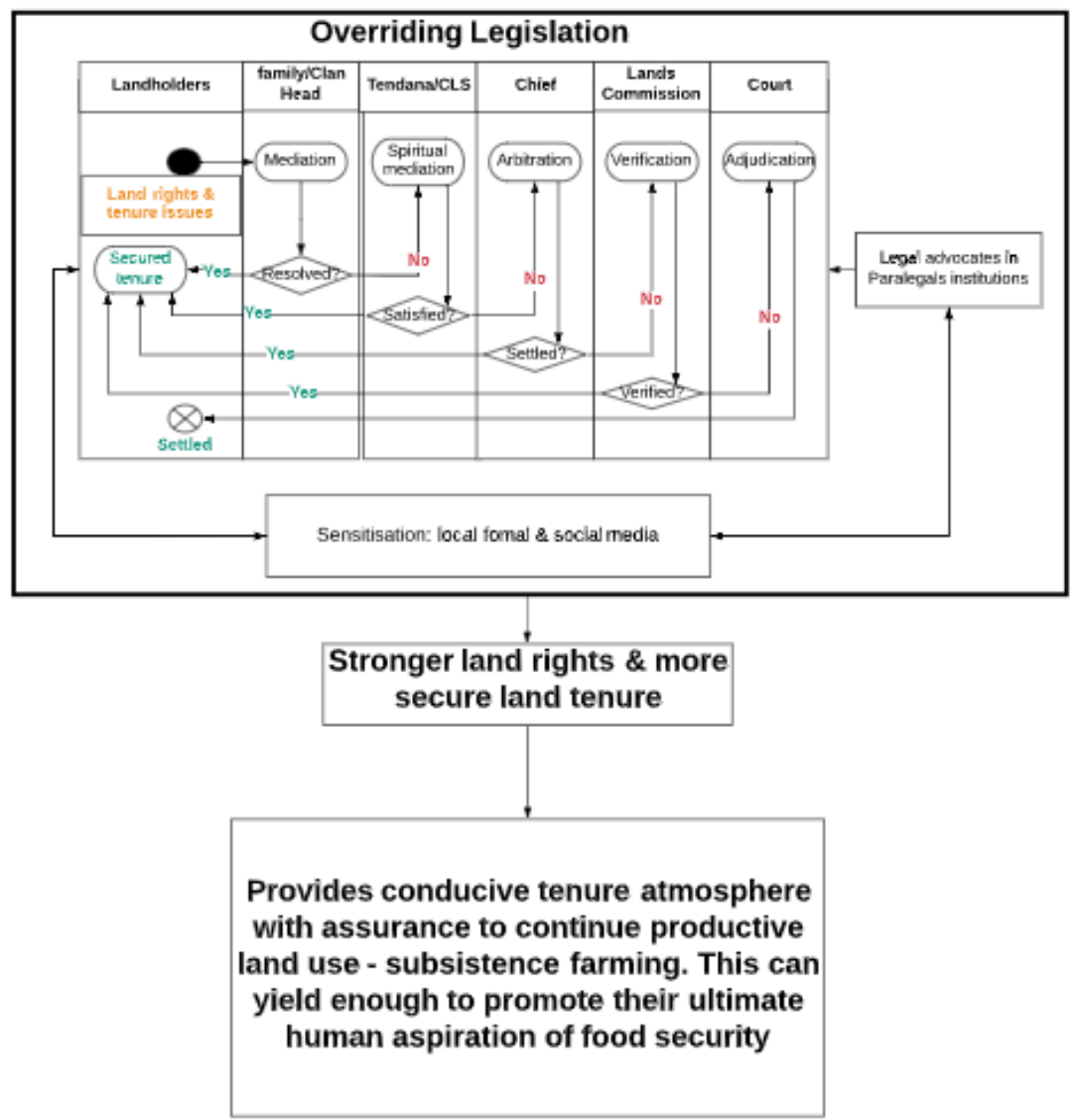

Figure 26 Responsible \& fit-for-purpose customary land rights \& land tenure model. Adapted from Nara et al., (2020b) - Identical to Figure 23.

Landowner elders emphasised that the law in the new model must compel endorsement from them before disputes can be taken to the courts. In the functioning of the new model and for it to not fail, one landowner from Sing had this to say:

"We landowners and our CLSs (but not chiefs) have to be the legally mandated starting point for all land dealings. That is, rights and tenure issues like allocations, renegotiations, disputes resolution and endorsing all land related agreements or documentations." And added that, "chiefs' role on the model will remain complementary i.e. to deal with civil aspects while the land-based bodies will deal with the pure land issues." "Of course,", another interjected with supportive expressions from others around, "the LC and NGOs may come in to help resolve our land tenure issues/disputes at specific stages when earlier customary attempts may have ended inconclusively especially at intercommunity levels. Meanwhile we think that when all the local level efforts fail after a maximum of three attempts, the legislation must be explicit that the 
matter be referred to the courts. And at the courts, a specific period be stipulated - not more than three years, [there were interrupting interjections as some wanted fewer and others more years. But they finally agreed that three years is reasonable] within which the courts must dispense justice subject to one chance of appeal for each party." "In addition," another continued, "if process exceeds the three-years duration, the legislation should automatically invoke "permanent vesting" of the disputed land in the state. This, we believe will compel us local people to hasten our resolution processes in order not to lose our land to the state. In addition, the model will function well and not fail when each stakeholder's role does not overlap with others."

There was consensus on the potential success of the new model as another landowner said that:

"The primary responsibility for the functioning of the new model rests with landowners and the local people to monitor and report any lapses in its functioning. NGOs may play intervention/complementary roles using ADR mechanisms. Government's role will be to exercise overall oversight responsibility on all land matters including to monitor proper legal representation for the vulnerable and marginalised people. Government will also ensure speedy resolution of cases in courts and supervise proper and adequate reparation for those whose rights may have been violated and in favour of whom the courts have ruled on cases. Our caution is that strictly upholding vulnerable people's rights will instill confidence of everyone in the new model so that it will not fail."

For the people, any neglect of the good aspects of customary norms and practices will affect the proper functioning of the model. They emphasised that no land case can be properly resolved without inputs from elders and local people who are the custodians of customs including on land. Consequently, one disabled, expressing on behalf of the others indicated that:

"We, the disabled people advocate that the operation of the model have to make some concessions for us as custom demands. We therefore suggest stiffer punishments for people who trample upon our land rights. In addition, cases involving us may be given priority over others involving abled bodied people. The new model we think will function well if the CLSs dutifully record all land transactions and agreements both the already existing and renegotiated ones."

Also, one settler participant expressing for all settlers raised that:

"Any arbitrariness in applying the new model based on the overriding legislation will obstruct its proper functioning. Staff of the CLSs can be composed of a mix of both land-based professionals and customary landowners for complementary handling of all land issues including rights and tenure disagreements. Since we are not landowners, we cannot think of being part of 
the CLSs even though it is good to consult us if any land deal involves the lands we are tilling otherwise when we resist, the model will fail. As users of the land, we know the owners better than some current generation landowners."

Settlers were quick to add that the functioning of the new model will likely be obstructed if landowners do not do anything to assure them (settlers) of some relief, as lands are increasingly getting scarcer in both rural and urban areas. For instance, another settler said that:

"When landowners engage in secret land sales, settlers will likely resist any development activities on their 'lands.' However, once we settlers can claim up to $40 \%$ of benefits or compensation accruing to or for the land we subsist on, plus a non-negotiable "free" land of between one acre in urban areas to two hectares in rural areas, then the model is good and will function successfully. It will not fail."

\subsubsection{Possible obstructions to effectiveness of new model}

Regarding important assumptions for which the effective functioning of the model is dependent, the respondents asserted that if the communities own the model, it will succeed otherwise it may become ineffective. They also mentioned that particular tenure insecurity indicators to be constantly monitored by all stakeholders. For instance, a common call from settler FGDs expressed by one was that:

"When local manipulations, arbitrary seizures and sale of lands by landowners cease, we settlers will stop land encroachments, refusal to attend/participate in communal land tenure meetings or issuing of various threats - sometimes we just cannot help it." Another added that "if the courts persistently delay in dispensing justice as we witness now, it will obstruct the effective functioning of the model. Furthermore, when "winners" in any land disputes also receive payments of compensation from losing parties through either customary settlement or court system, then the model will function effectively. Otherwise, as in the current situation (in Figure 24) without compulsion, there is no incentive to abide by conventional settlement of land rights and tenure disagreements. It will be a waste of our time and our little money in transportation and other costs to and from court. So why will we comply?"

Again, some FGD participants mentioned that persistent arbitrary land conversions and unannounced developments by outsiders (land developers) could cause the new model to malfunction in their context. To that effect, another settler added that:

"All stakeholders especially the landowners have to watch out and work against secret land sales, non-consultation with settlers and non-renegotiation stipulations when the new model is implemented. For the model to function effectively and efficiently, transparency is essential for us. Moreover, whenever land rights and tenure related misunderstandings happen, we all have to 
speedily deal with them before they worsen. Thus secrecy, greed and disregard for our [settlers] land rights will obstruct the proper functioning of the model." On the obstacles that may stand in the way of an effective and efficient model from the perspective of landowners, a landowner (tortina in Nimoro) mentioned that:

"We expect that settlers and other secondary land rights holders will abide by the overriding legislation and indeed the new model. In addition, outsiders (except government) do not have to meddle in local land rights and tenure security affairs until they are directly invited. For us, such intruding outsiders may be misconstrued to have a stake that opposes ours. We will be reluctant to comply with the new model in such instances because of suspicion of biases from outsiders (intruders). In addition, if we are disregarded in handling land issues including resolving land rights and tenure challenges, we will not also comply with such outcomes or verdicts and this will obstruct the proper functioning of the new model. We want to be directly involved especially regarding customary aspects as that will facilitate the proper functioning of the new model."

Some of the research participants (particularly women) also indicated that at the sensitisation front, the mainstream media and customary channels at local gatherings have to endeavor to praise publicly on acts of compliance with the new land rights and tenure model and the legislation backing it. On the other hand, they suggested that non-compliant persons and actions must receive public condemnation to discourage further or other violations. Additionally, they pointed out that high, cash-based and non-flexible costs to parties trying to resolve their tenure disagreements may obstruct the model's effectiveness as such parties will not even patronize it or skip some stages of the model's order which can cause its failure. Women therefore suggested flexibility in fining and receiving fines. For instance, the use of manual labour and public apologies, use of farm produce to redeem charges of offenders will be effective and cause the model to function well. Also, the victims of land rights violation could be entitled to some claims through those settling the tenure disputes from payments made by the defeated party."

Finally, settlers mentioned that an obstruction to the success of the new model will be the current practice of making both parties pay monies to customary elders for resolving disagreements. Instead, elders at the end of resolving any disagreement have to impose fines on the losing party alone as it is practised by the courts. The victorious party walks away without any charges and in addition, receives part of the fines as compensation for the inconveniences and damages suffered before, during and after the litigation. 


\subsubsection{Testing the model}

The researcher conducted a summary exercise to test and confirm the feasibility and success of the new model among 12 representatives in each community using a Likert scale. The direct question posed to the participants of the joint workshops was:

The new land rights and tenure model will function effectively, efficiently and successfully. To what extent do you agree or disagree. Explain your choice. The options to them were: Strongly agree, Agree, Disagree, Strongly disagree.

There was that fear of exposure by the media (mainstream, customary and social) which 'compelled' some people to comply. During the role play session, respondents were asked why they were complying with almost the same processes that were hitherto disregarded and they pointed to the overarching legislation.

The least used institution within the model was the legal advocates. We therefore asked whether it should be taken out of the model. The people said it was necessary to maintain it to empower the vulnerable and marginalised people. And added that the absence of advocates can be a weakness that some powerful people may want to exploit later on.

The results from the joint community workshops show varying anticipated success levels. The reasons for these differences are due to the nature of the inherent existing relationships between and among communities.

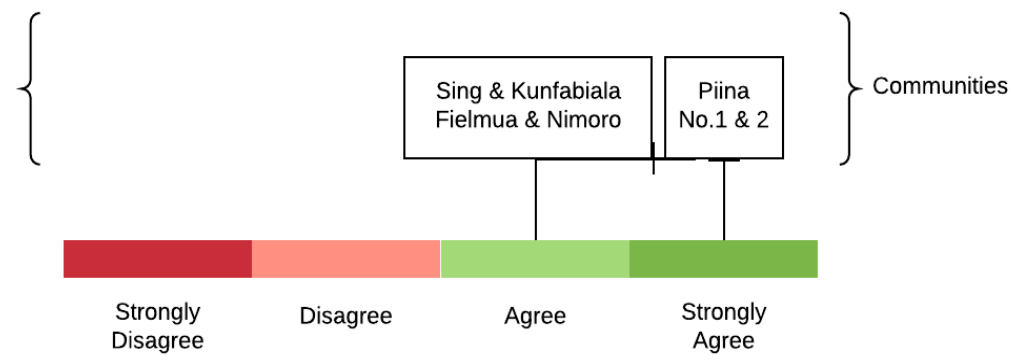

Figure 27 Mock-testing communities' trust in model's feasibility. Author's construct from fieldwork (2021)

Generally, all the communities foresee the model's success largely, but on conditional basis. For instance, landowners state that when settlers and all secondary land rights holders comply and observe their roles in the new model, then it will succeed. Settlers' condition for model's success is transparency and respect for everyone's land rights. In general, as shown in Figure 27, both landowners and settlers in Piina were the most optimistic (i.e. strongly agree) 
about the success of the new model. Out of the three pairs of communities visited, the people of Piina number 1 and Piina number 2, report experiencing minimal land rights and tenure challenges. Some of the reasons they adduced for this include mutual respect for peaceful co-existence for common development. They also desire to uphold ancestral agreements and they practice inter-ethnic marriages to strengthen their oneness. Furthermore, they reported of engaging in cordial daily interactions between the two groups such as at local gatherings (market, funerals and festivals). These interactions are very minimal between Fielmua and Nimoro communities. In Sing, one intermarriage was mentioned yet there is less tension between landowners and settlers. There is however, some slightly related tension among landowners in Sing at the time of compiling this paper due to an impending land compensation package which they are about to receive from government. The compensation package is in respect of part of the land taken by government in Bamahu, Wa to establish the University for Development Studies (UDS) which has now been converted to University of Business and Integrated Development Studies (UBIDS). The youth are suspicious that elders may want to withhold the chunk of the money to the disadvantage of they the youth, hence their apprehensions.

\subsection{Discussions}

This research aimed at validating a land rights model referred to as responsible and fit-for-purpose that is holistic and locally engineered i.e. co-created with local communities. It was set to assess the possible effectiveness and proper functioning of and, likely obstructions to the model towards strengthening land rights and securing land tenure. It then verified how these land rights (strong or weak) may be influencing food security as a consequence. Its target group is predominantly the vulnerable and marginalised subsistence farmers in local communities. The test is based on the new model's anticipated effectiveness to assist these farmers' access relatively strong land rights and more secure tenure to boost local investments in farming for food to sustain their households.

Testing land rights and tenure model in the communities was done to estimate the people's level of confidence in the workability of the model. It was tested through beneficiaries' responses, choices and voting in terms of numbers in a role playing (or drama) session. The process showed who or how many agree to or oppose the effectiveness of various aspects of the model when implemented. That is, the extent to which indication shows on the ground and drawing lessons from theory to support the interpretations of test scores obtained from users of the model. Again, the people used everyday land rights and land tenure issues/problems so that their attempts to address them will reveal the possible obstructions and feasibilities. Some acted as victims while others acted as persons and institutions in the model and acted using the 
arrangements in the model to deal with the problem. In the process, various issues came up and were dealt with to the satisfaction of all present.

\subsubsection{Effectiveness of new model}

The effectiveness of a model means that it is able to meet specified (and in this case anticipated) performance requirements, targets and aspirations as opined by Rykiel et al., (2011). In this case, once the model is known and deemed by the people as capable of strengthening land rights and securing tenure in order to promote farming and ensure food security, then it is considered to be effective. For Mulolwa (2002), an effective model may not be entirely new to the local people as in the sub-Saharan African context. Rather, it is usually a combination of already familiar principles, practices and systems of local people with some elements of other models in use elsewhere. In line with Mulowa, this new model used the existing and current customary norms, practices and rules in combination with other experiences as contained in literature to co-design the new model. Boudreaux \& Sacks (2009) posit that effective models are those that exist with the government playing a lead and oversight role to protect the weak. That is, the fundamental role of national government to provide an overarching legislation (Nara, Lengoiboni, \& Zevenbergen, 2021). For instance, Section 15 of Ghana's new Land Act 2020, Act 1036 and an efficient adjudication system lend credence to this new model and can facilitate its effectiveness to enable local people meet their aspirations. This implies that as Mulolwa hinted earlier, effective models are locally engineered i.e. co-created by working with local people. In that light, this fitfor-purpose (FFP) model was co-created with some level of external facilitation. Regarding external assistance, the mainstream media involvement in this FFP model can help sensitise people about it and its abuses to make it effectively strengthen land rights and secure tenure. This is expected to promote local farming for food security. The effectiveness of the new FFP model may also be assured given the fact that it is based on the current local means of information using local "attention-seeker" gadget for making announcements and at local meetings. This strategy is corroborated by Bugri (2010), who posited that effective models also make use of local channels of information flow and sensitisation. This further corroborates the assertion of Ballard, Kepple, \& Cafiero, (2013) who opine that "even though information alone is clearly insufficient yet, it can be a powerful tool to create awareness, acceptance and patronage of a new system, model or policy." In addition to mainstream and local media, this paper contends that under current circumstances of high need for information by especially the youth and middle-aged people, social media can also play a vital role through quick dissemination of information on land rights issues. This can make effective this FFP land rights and tenure model. 


\subsubsection{Functioning of the new model}

According to Allameh, Harooni, Chaleshtari, \& Asadi (2013); Lynn (2015); Srikanth \& Jomon (2013); Yadav \& Rangnekar (2015) better clarity and less ambiguity regarding individual group or organisation roles can facilitate functioning and performance significantly. Therefore, the relatively clear roles of stakeholders in this new FFP model can make it function properly where positions in the hierarchy are respected as such. For instance, the CLSs and tendamba for that matter being part and in fact the first point of call in all land matters ranging from allocation through documentation to dispute resolution can make the model function smoothly. On the backdrop of this, it requires the non-involvement of chiefs in land issues in this area except civil issues connected with land matters.

Speedy resolution of disputes can also facilitate the functioning of the FFP model. Ostrom \& Hanson (2010); Swigert \& Farrell (1980) in different studies found that cases adjudicated promptly result in higher conviction rates thereby instilling confidence in the functioning of the system (in our FFP model) than those which are delayed. For better model performance to occur in this case, government (holding oversight power on all matters in the country) may vest in itself disputed land that remain unresolved after three to five years. Furthermore, if after five more years (making it 10), parties do not reach a compromise by themselves, then they both lose the land permanently to the state. In this way, a ten-year moratorium (period for a compromise) may be made available to parties and if they fail to reach that compromise, then the land remains state property forever for public good which may ultimately restore "peace" once there is "nothing to fight over." This is possible as local people already claim (rightly or wrongly), that government - the law is "bigger" (i.e. more powerful) than its citizens and they cannot fight/disobey it.

For proper functioning of a model, consultation is key (Gifford, Fiona, \& George, 2005; Green \& Herget, 1991). Hence, consulting secondary land rights holders if their land is involved in disputes, allocation, documentation etc. may facilitate the model's smooth functioning. And this is very much part of this FFP model.

In addition, regarding compensation payments and receipts, it is important to note the almost perpetual interest of secondary land rights holders in the context this study area. In that light, for them to help in the proper functioning of the model, their interest beyond current developments on the land is key. Once, they are assured of this, their support and cooperation will enable the model to function well. Karia \& Omari (2017); Mabaso \& Dlamini (2017) said there is a statistically significant relationship between compensation receipts, satisfaction of beneficiaries and their cooperation leading to organizational (system or model) performance. And therefore, suggested that compensation should be provided expeditiously so as to enhance performance of both 
employees and organization (as with local people and their land rights and tenure model). Therefore, simple involvement of and co-creation with local people in land rights and land tenure model design, monetary payments for compulsorily acquired lands, resettlement packages and other forms of respite can attract local support for the functioning of this FFP model.

\subsubsection{Possible obstructions to effectiveness of new model}

Capaldo et al., (2010) believe that socio-cultural issues/challenges can best be solved through the use of laid-down systems like an FFP model which is effective. But generally, system or model effectiveness may be obstructed where some or all of its aspects are neglected, manipulated or taken for granted by those placed in authority to enforce it. And may be due to sociocultural, political or economic expediencies among others. Also, as Chigbu \& Klaus (2013) put it, inadequate participation or what Galvagno \& Dalli (2014); Ind \& Coates (2013) refer to as co-creation (when it is lacking), can significantly obstruct model effectiveness. This was clearly demonstrated when during the role-playing sessions in the study area, some victims of land violations refused to cooperate in abiding by the tenets of the model and it eventually broke down. For Mulolwa, rights and obligations as well as commitment and attitudinal change are necessary for an effective model. Indicating that a deviation from these can obstruct the effectiveness of any model. In support of this assertion, there were instances when the right of a settler to be consulted by landowner before attempting to change his/her land rights were neglected. Such victims resisted anybody who entered the land as a new owner/developer of land. These victims/settlers stated that the current land rights model had been in use since time immemorial without much difficulty. And emphasised that landowners must employ similar practices used in the past to avoid any possible failure of the new model. As change is inevitable, significant transformations occurred in the past regarding land ownership, transfers etc., yet, little social tension and tenure insecurity were prevalent. However, since Ghana's independence, many of its communities experienced population explosion and urbanisation following government upgrading of their political or administrative statuses. This seems to influence arbitrary seizures and sale of lands by landowners and this compelled secondary land rights holders, particularly settlers and others who feel marginalised to begin disregarding (by manipulating, neglecting or taking for granted) the very model - norms and practices that were largely regarded as peaceful. In addition to that, the concurrent operation of the dual land management system (formal/legal and customary) in Ghana and the study area caused some confusion. People sometimes do not know whether to go by the customary or legal/statutory system. Furthermore, the legal/statutory system did not seem to provide the needed justice delivery that the customary people expected and made many to resort to other ways of protecting their land rights. For instance, the formal system was thought to issue non-deterrent 
sanctions or showing partiality in adjudication, thereby causing disaffection among local people who prefer other undesirable options.

Customary agreements based on the current (ancestral model using oral tradition) have some renegotiation clauses as and when the need arises. However, in an increasingly commodified land-dependent society of today, stipulated time-bound explicit renegotiation periods may be required without which the FFP model functioning may be obstructed. Land issues that are characterised by non-transparency, external interference, less sensitisation with too much emphasis on money were mentioned by the people to be capable of obstructing the functioning of the model since the wealthy people will always have their way and the weak losing out. Hence, the current Land Act 2020, Act 1036 in Section 13(3), emphasises transparency by fiduciaries of land and failure of which attracts legal sanctions.

\subsection{Conclusion and policy recommendations}

This research aimed at testing the co-created model, referred to as responsible and fit-for-purpose - FFP. It assesses land rights/tenure security influencing food security as a consequence. The test is based on the model's anticipated effectiveness to assist farmers access relatively strong land rights and more secure tenure to boost local investments in farming for food to sustain their households.

This research tested this model using communities' own aspirations, needs, suggestions and commitments (i.e. user requirements) based on the following measurement criteria set out in the objectives. They are, factors that may promote the effectiveness of the model, ingredients for proper functioning of the model and the possible obstructions to the effectiveness of the model.

The outcome shows that the challenges in the communities' current land rights and land tenure model have been identified. Secondly, the solutions to these constraints were co-created together with the communities. This qualifies the designed model as fit-for-purpose - FFP which Enemark, Bell, Lemmen \& McLaren (2014) believe "to address current constraints and allowing for incremental improvement over time to be regarded as effective."

Literature suggests that isolated implementation of either the current old or adopted model, cannot effectively promote strong land rights and secure tenure (Mulolwa, 2002). This informs that a combination of models is the best strategy. But this must be in addition to a strong attitudinal change and commitment from all stakeholders. The communities demonstrated willingness and commitment through their active participation during the co-creation of the model. Change/risk management as a major dimension of the implementation of this model is emphasised. This is because implementation of well targeted and coordinated projects (model in this case) within the 
organisation can provide major organisational changes leading to effectiveness and efficiency (Kuzmanova \& Alexandrova, 2017). Meanwhile, proper management is required to ensure the effective implementation (Munassar, Ghanim, \& Ahmad Dahlan, 2013). All projects involve an element of organizational change and so both project management (like model implementation) and change management have a role to play in delivering desired changes or aspirations (Pollack 2017). Therefore, appropriate risk management strategies referred to earlier, can help reduce landlessness and make land available for farming to produce food for improved food security. The clear roles of all stakeholders in the new FFP model can facilitate and improve public policy design and targeting. The assurance of appropriate management in the new model is the inclusion of customary institutions, people and practices. It gives dynamism in social land tenure relations needed in this model without which its functioning will be obstructed. This model deemphasises land ownership and emphasises its use rights, thereby re-assuring people of its sensitivity to their interests.

Finally, this model may require some adjustments during implementation to fit in each unique customary land management system to be adequately effective. Particularly, the involvement of government actors who were not directly included in this mock-testing exercise. 
Chapter 7 Synthesis 


\subsection{Introduction}

The need to achieve global food security has been emphasised time and again as fundamental for survival and for living an active and healthy life. This need is largely supported by all as championed by the UN and requires a multifaceted approach to succeed. One of these approaches is strengthening land rights of smallholder farmers in Sub-Saharan Africa's northwest Ghana. The problem identified in this research revolves around weak institutional control measures and poor enforcement of tenure laws giving rise to tenure uncertainty among the predominantly agrarian subsistence (settler) farmers. Ghana's new Land Act 2020, Act 1036 recognises this need to strengthen institutions (both customary and legal/formal) in order to achieve desired results in land administration and land management.

In chapter one, the author assesses customary land rights variations and inequalities among smallholder and subsistence farmers within socio-cultural, economic and political circumstances of the study communities. It found land rights and tenure security to be based on the social structure of the communities. Groups who are high on the social ladder appear to possess more and stronger rights than those lower on the social ladder in those communities. It also found that male (and indigene) landowners are generally higher on their social structure. In line with the tenets of the social structure theory, male landowners (indigenes) possess stronger and more rights in the bundle of land rights. Therefore, non-indigene males (i.e. male settlers) possess weaker and fewer land rights. Unexpectedly however, females who come from the landowning group rather possess weaker and fewer land rights and tenure security than settler males and similar to that of settler females. It concluded that measures need to be taken to narrow the land rights and tenure insecurity gap in order to minimise the associated negative implications on weaker groups' productive use of land and its consequences. Chapter two, then examines the implications of these inequalities for household food security in the region. The research establishes a relationship between land rights security and food security. It then identifies the problem of fewer and weaker land rights having the potential to discourage farm investments. Consequently, there is less farm yield, less food to consume or sell and therefore, high susceptibility to food insecurity in terms of both availability and accessibility. Chapter three ascertains how the challenges of changing customary tenure and service arrangements of subsistence farmers can be tackled to improve land rights, tenure security and food security. It delves deeper into the influences of community land rights and tenure security intervention processes on food security. The chapter identifies that the hitherto communities' own ways of resolving land rights and tenure challenges are weakening. And there is therefore a need to blend customary processes with models from other jurisdictions as well as local and national legislations (like Ghana's new Land Act 2020, Act 1036) to help address the challenges therein. Based on this, 
chapter four designs through co-creating a fit-for-purpose model to improve land rights and land tenure security to support food security. This aspect took cognizance of the role of the new Land Act 2020, Act 1036. This is particularly found in Section 13(6)a - imploring that customary procedures be exhausted first - to strengthen institutions and promote compliance of land tenure laws etc. Mock-testing the implementation of this model is contained in chapter four. It is apparent that the new fit-for-purpose model can be implemented in the study area in its current format, although it will need adjustments to fit in other jurisdictions due to contextual differences in land tenure arrangements and practices. The synthesis of chapters two to six come in chapter seven.

Section 7.2 summarises the main findings of each of the objectives while 7.3 discusses the implications of the results for scientific knowledge and local or public policy formulation.

\subsection{Main Findings}

The summaries of each of the four main objectives are contained in this section.

\subsubsection{To assess the changing customary land rights and tenure security inequalities among subsistence farmers in northwest Ghana}

The basis of this first objective emanates from various studies including Gebrehiwot (2012) who stresses the need for access to land with secure tenure of smallholder farmers. There is another by Lawry et al., (2014) which emphasise secure and predictable access to land for improving livelihoods through agricultural production and food security, though attention is on large scale farming. A study by Akrofi \& Whittal (2013) hints that land rights in peri urban Ghana are skewed against women. What is lacking in all these studies is the fact that in addition to women, land rights of other categories of smallholder farmers are also unfavourably skewed which tend to affect farming, food availability/accessibility and subsequently food security. This objective therefore, assesses land rights inequalities among smallholder farmers on customary lands in northwest Ghana. Knowledge of these variations can play a key role in finding a lasting solution to smallholders' land-based production capabilities. The results of this deep analysis show that women in general and settler males who constitute majority of residents in the study area possess smaller parcels of land and fewer land rights which are also weaker as compared to landowners in general. This situation results in wasted land of fewer landowners and wasted labour of the majority women and settlers thereby inhibiting productive use of land for example for farming, food availability, accessibility and food security. These inequalities and their implications were traceable to challenges associated with the existing land rights and land tenure model being operated in the area. The current land rights and tenure model therefore needed to be modified to bring fairness to all categories of smallholder and subsistence farmers. This can be done by first 
ascertaining the specific challenges with the existing model through communities' land rights and land tenure security intervention processes that influence land-based production such as farming.

\subsubsection{To assess the implications of customary land rights and tenure security inequalities of subsistence farmers for food security in northwest Ghana}

Land tenure security in general has various implications for livelihood and especially for food security (Chigbu \& Klaus, 2013; de Vries, Chigbu, 2017; Lawry et al., 2014; Ruerd \& Policy and Operations Evaluation Department (IOB) Ministry of Foreign Affairs, 2011). It is further emphasised that tenure secure people can access and maintain larger farm sizes which in Sub-Saharan Africa is still quite a prerequisite for increasing farm produce, ensuring food availability and also promoting the other forms of food security - accessibility, nutrition and stability.

This chapter contributes to literature by detecting that different categories of people are affected differently based on the strength of their land rights and their level of tenure security. For instance, male land rights are generally stronger yet this study found that the high level of food insecurity among subsistence settler male farmers is related to their weaker land rights as compared to male landowners. Similarly, while all females in the study area generally possess the weakest land rights, females from the landowning group seem more privileged in terms of tenure security and food security than those from the settler group. Also, while the disabled are generally thought to be marginalised in resources distribution, this study found otherwise. Land rights inequalities in the study area are therefore determined more by settler and landowner statuses and gender than disability. As a result of the above situation, all females followed by settler males were found to be more food insecure than male landowners. The study further examined land rights inequalities in rural and urban areas and confirmed literature that urban areas are more tenure insecure than rural areas. As a result, they are experiencing reducing food supply from farming as compared to those in the rural areas. Other implications of tenure insecurity in the urban area were mentioned by FGD participants as social tension and suspicion as posited in the work of Bitir \& Nara (2016) towards promoting good local land governance in Ghana.

This study therefore suggests that local and central government need to put in more inclusive intervention strategies to narrow the land rights and land tenure security differences among the various categories identified. This kind of intervention has the potential to improve the food security and enhance social cohesion of these marginalised and vulnerable groups/areas studied or in other parts of Ghana and beyond. 


\subsubsection{To ascertain how challenges of changing customary tenure and service arrangements of subsistence settler farmers can be tackled to improve land rights, tenure security and food security}

The relationship between land rights and its tenure security influences on food security has been emphasised in various research works (van Asperen \& Mulolwa, 2006; Capaldo et al., 2010; U. E. Chigbu \& Klaus, 2013; Duncan \& Brants, 2004; FAO, IFAD, UNICEF, WFP, 2018; Holden \& Ghebru, 2016). These scholars mentioned issues of land access, tenure security and the ineffectiveness of implementing foreign-based models in local settings. However, little has been said about how aspects of the existing local land rights and tenure model may inhibit the ability of people to adequately secure their rights to enable them to fully make productive use of land in their possession. Meanwhile, land access in the study area is much less problematic than the security of its tenure. Therefore, emphasis in this research is on ensuring certainty of the tenure terms, processes and duration with a renegotiation clause among others.

This chapter particularly identified and analysed the challenges that communities face within the customary land tenure system that tend to inhibit the productive use of land e.g. for farming. According to Rao, Spoor, Ma, \& Shi, (2016), these difficulties have caused farmers to often suffer evictions, reduced farm sizes, experience land rights variations and uncomfortable inequalities. Even as these have consequences for food security, they seem to be supported by the local land tenure arrangements or practices. These happenings are caused by some weaknesses of existing laws, absence of appropriate legislations and poor implementation of existing land laws. For example, customary land rights and tenure arrangements in the study area are not documented and hardly enforced by formal laws. Literature has shown that many governments in Sub-Saharan Africa (SSA) seem to believe that land registration/documentation is the panacea to tenure security. It is partly in response to this kind of intervention from SSA governments that Zevenbergen, Augustinus, Antonio, \& Bennett, (2013) caution that documentation alone cannot secure land tenure. These authors specifically point out that land tenure is insecure especially in environments with a weak legal framework, low institutional capacity and possibly less commitment to implementation of available intervention strategies or laws. Based on the research findings and evidence from literature, this research then suggests through co-creation, responsible land management interventions from local practices (or model), blending with aspects of some external models to strengthen land rights and enhance subsistence farming for food security.

\subsubsection{To design a fit-for-purpose model that can improve land rights \& land tenure security} leading to food security of subsistence/smallholder farmers in northwest Ghana

One purpose of identifying problems is to find the most feasible and lasting solution that is acceptable and fit-for-purpose for the affected people. In this 
section, the effectiveness of local land rights and land tenure models or practices have been synthesized from the previous two objectives and some aspects of customary land tenure were found to have been either weakened or less supportive of stronger land rights of vulnerable groups. Consequently, customary lands no longer provide the kind of tenure security assurance for local people currently as it did in the past. This has resulted in a reduction of overall farm outputs from such lands under customary system. It then culminates into less food production which tends to reduce the affected people's food access and therefore threaten food security in the area among most subsistence/small-scale farmers. The review of literature in relation to this research reveals that the wholesale adoption of foreign-based land rights models for local customary settings have not worked successfully. Such models mostly do not fit the socio-cultural environment within which local traditional customs on land apply. A resultant confusion or so, ensues thereby rendering the efforts by African governments in the past unhelpful in resolving land tenure challenges in the sub-region. Besides, higher costs were associated with land registration for instance, to secure its tenure. Based on the aforementioned, it became eminent that the best strategy going into the future, will be to co-create a model that takes into consideration both locally familiar practices and foreign-based effective best practices. The result of this blended approach is to design a responsible and fit-for-purpose land rights and land tenure model in this objective. The FFP model involves the participation of government with an overarching (overriding) legislation to encapsulate all land rights and tenure norms and practices in the local area. This is important due to the prominence (albeit criticised) of the court system in Ghana as the final arbiter over the customary system of adjudication. With legal backing and setting up of satellite offices from the community to the national levels, these bodies could execute specific land tenure related tasks with little or no additional cost to the state and individuals concerned. And with this, the problems of tenure insecurity and consequently food insecurity could be resolved.

The new FFP model also now actively involves the media (mainstream, local and social), to disseminate any information relating to land - availability, accessibility, tenure security, abuses etc. This fit-for-purpose approach is also cost sensitive as in employs a strategy that allows alternative payment modes like the use of either or both cash and kind (labour supply or paying with grains or animals) instead of the previous cash-only option. The touted free media in Ghana coupled with people's general unwillingness to come into conflict with the law have potential to ensure cooperation and compliance. Furthermore, the stiffer punishment system (including public condemnation) in place in this new FFP model could deter culprits. And more importantly, public commendations for compliance in the implementation of the new FFP model can potentially encourage people to respect others' land rights. 
7.2.4 To mock-test the implementation of the new fit-for-purpose model towards improving land rights \& land tenure security of subsistence farmers to promote farming, food availability and food security

The feasibility of this model is dependent on it passing a test to determine its success during implementation or at least in a mock or role play forum by some representatives of beneficiary communities before actual implementation. This preliminary test is required as a basis to provide tolerable assurance to encourage the model's adoption. The results of the test indicate a high level of optimism and feasibility for the model's potential to strengthen all people's land rights with a consequent possible improvement in farming, food production, food availability and food accessibility. Additionally, the model has the potential to positively influence nutrition and food stability too. The test shows a need to maintain most customary land rights and land tenure practices that now should include flexible and alternative terms of payment that include non-cash (i.e. kind) options like labour supply and use of other farm yields in addition to cash payments. This new model is protected with and empowered by an overarching legislation to persuade or compel people to comply with 'their own tenure practices'.

The persuasion emanates from the vibrant and effective Ghanaian media while the compulsion comes from a robust arbitration and adjudication system from the courts or the alternative disputes resolution (ADR) mechanisms. Thus, the paralegal services approach has been provided for in the new FFP model to assist the vulnerable at low (or no cost) to victims of land rights abuses and no additional cost to the state. Another inclusion in the new model is solicited external support from land rights and other NGOs that aim to promote food security and general socio-economic wellbeing of people. The addition of for instance, first five years 'grace or undisturbed' tenure term followed by new stipulated avenue for tenure re-negotiation provides some respite for both landowners and secondary land rights holders to trust the new model. The absence of (or weakened) renegotiation option is one main cause of disregard for customary tenure norms and practices coupled with poor legal enforcement of tenure laws. In order for the new FFP model to succeed, participants call for a general commitment from all stakeholders and this the participants themselves assured of it during the testing process. They are therefore confident that this commitment can be available during the actual implementation of the new fit-for-purpose land rights and tenure model.

\subsection{Implications of the research results}

The research results have various implications for academia/knowledge/literature, policy and harnessing social synergies in Ghana as outlined in succeeding paragraphs. 


\subsubsection{For literature}

In terms of knowledge, this work adds the case of customary land rights and land tenure issues as they affect the productive use of land. That is, of subsistence and smallholder farming for food availability. This work further adds the fact that for this specific context, the people's food accessibility, nutrition and food stability all depend on their food availability through farming. Another contribution to literature on land rights is the fact that the seemingly homogeneous local people are internally different based on the social structure of the area. For instance, an outsider would hardly notice any land rights inequalities or differences between landowners and settlers just as it would be difficult to notice that some residents in the local community are indigenes and others being strangers unless an in-depth investigation is carried out in the form of this research. Duncan \& Brants (2004) provides in the literature that women are marginalised in terms of land rights and ownership in Ghana. This work clarifies this marginalisation to the extent that females from the landowning group who are placed higher on the social structure, rather have fewer and weaker land rights than settler males who are lower on the social structure. This work also unearths and adds to literature the specific plight of various groups like disabled, females and settlers in the local community in terms of land rights. There was very little of this information particularly about settlers in the existing body of knowledge on customary land rights and land tenure on north west Ghana. The use of satellite imagery for triangulation purposes in this context is novel and reveals a deeper need for inclusion of GIS technologies in works of this nature in the area.

\subsubsection{Public or social policy issues}

This work is relevant for policy makers to take the micro-level land rights inequalities into consideration when formulating macro-level policy interventions to promote farming, increase land access and strengthen land rights for farming and for food security. This is important for targeting the most vulnerable groups and providing specific intervention strategies for a lasting solution.

\subsubsection{General community development and social cohesion}

This work is relevant in revealing that in spite of the seeming differences between various social groups in the communities, the people are still collectively desirous of strengthening their ties for their community's development. To this end, the study showed that the people deliberately encourage marriages across the groupings, especially between settlers (or migrants) and landowners (indigenes) to lessen any potential land tenure and other tensions between them. 
This study informs on Ghana government's policy on security or otherwise of landholdings by different categories of farmers in order to decide how to actualise its Planting for Food and Jobs programme launched since mid-2017.

\subsection{Validity and Reliability of the Research: Generalisability, ethical considerations and expected impact on theory, policy and practice}

The validity of this research was established based on its design and use of a variety of appropriate methods, techniques and tools through triangulation (Kaulio and Karlsson, 1998). It is expected that results from this study can be a pointer to similar situations in other customary areas in parts of Ghana and beyond. Interventions can be introduced with minimal adjustments to reflect the spatio-temporal, socio-cultural, economic and political context peculiarities.

This thesis passed through ethical review conducted and facilitated by domainspecific committees of Humanities \& Social Sciences and Geo-Information Sciences. Anonymising respondents' identity and responses was paramount. Their individual or collective consent was obtained individually and collectively through their leaders - chiefs. The validation of the data was carried out after data compilation ensuring that it reflects their situation and their actual views given out earlier to the researcher.

The data in relation to this research (especially the personal data) is being managed/stored in the University's data management centre and can only be accessed by others after obtaining express permissions from the University and the researcher.

\subsection{Limitations of the study}

Due to socio-cultural dynamics, the results of this research may not be readily generalizable in other regions in Ghana and elsewhere outside of the country. These social and cultural variations can affect the application of land rights laws, norms and practices in different areas and therefore call for a closer interrogation for any such specific context-based changes to reflect any such research works. The use of deeper GIS satellite imagery and modelling could further improve the precision of some quantitative information in the field. For instance, size of farmland gained or lost in this study were largely estimates given by FGD participants etc.

\subsection{Future research prospects}

The limitations outlined above raise questions for future research. It would be interesting to know more about land rights inequalities among and across 
groups in different socio-cultural contexts (beyond this study). And also, their differential effects on food security in future research of this nature.

A deeper use of GIS satellite imagery in works of this nature can provide further insight into precise farm or plot sizes and the differences therein across various groups.

Furthermore, yield detection research objectives can be set and investigations made in future research for this context to determine the exact impact of land rights inequalities rather than that based largely on only the respondents' estimates.

Also, a longitudinal study to see how this FFP model for land tenure and food security performs in the long run can also be carried out in future research.

Finally, unimpeded information from active media involvement in the Ghanaian context is a key strength of this FFP model. However, the adjustments the FFP model calls for when replicated elsewhere may be the media aspect. This is because of the restrictions imposed on freedom of the media in other jurisdictions outside Ghana. This can inform the way forward for securing land rights in specific places in support of food security in future research on this subject. 


\section{Bibliography Bibliography}

(FSIS), U. D. of A. (2005). Model Food Security Plan for Import Establishments.

Abdul-Korah and Gariba, B. (2007). 'Where is not home?': Dagaaba migrants in the Brong Ahafo Region, 1980 to the present. African Affairs. https://doi.org/10.1093/afraf/adl023

Abdul-Korah and Gariba, B. (2008). Labor Migration among the Dagaaba of the Upper West Region of Ghana, 1936- 1957. Nordic Journal of African Studies, 17(1), 1-19. Retrieved from http://www.njas.helsinki.fi/pdffiles/vol17num1/abdul-korah.pdf

Abubakari, Z., Richter, C., \& Zevenbergen, J. (2018). Exploring the "implementation gap" in land registration: How it happens that Ghana's official registry contains mainly leaseholds. Land Use Policy, 78(March), 539-554. https://doi.org/10.1016/j.landusepol.2018.07.011

AEC. (2004). Land Tenure Systems and their Impacts on Food Security and Sustainable Development in Africa. Economi Commission for Africa. Retrieved from http://www.uneca.org

Akrofi, Emmanuel Offei, Jennifer Whittal, C. A. (2013). Assessing Customary Land Administration Systems for Peri Urban Land in Ghana. University of Cape Town.

Akrofi, E. O., \& Whittal, J. (2011). Traditional governance and customary peri-urban land delivery : a case study of Asokore-Mampong in Ghana. AfricanGeo, (October 2016). https://doi.org/10.13140/RG.2.1.4056.0480

Alemie, B. K., Zevenbergen, J., \& Bennett, R. (2015). Assessing Land Governance in Ethiopian Cities (2002-2011): Lessons for the Implementation of the 2011 Urban Land Management Policy. FIG Working Week, (May 2015), 17-21.

Allameh, S. M., Harooni, A., Chaleshtari, M. S., \& Asadi, A. (2013). Investigate the Relationship between Variables and Role Clarity Effects on the Perceived Service Quality of Front Line Employees ( Studied on the Clerks of the Keshavarzi Bank in the Province of Chaharmahal-EBakhtiary ). International Journal of Academic Research in Business and Social Sciences, 3(5), 127-138.

Almeida, B., \& Wassel, T. (2016). Survey on Access to Land, Tenure Security and Land Conflicts in Timor-Leste, 41. Retrieved from http://asiafoundation.org/publication/survey-access-land-tenuresecurity-land-conflicts-timor-leste/

Alston, L., \& Mueller, B. (2015). Towards a more evolutionary theory of property rights. Iowa Law Review, 100(6), 2255-2273.

Ameyaw, P. D., Dachaga, W., Chigbu, U. E., De Vries, W. T., \& Abedi, L. (2018). Responsible land management: the basis for evaluating customary land management in Dormaa Ahenkro, in Ghana. World Bank Conference on Land and Poverty Conference, March 19-23, 1-18.

Amuzu, A., Osei-akoto, A., Anum, J., Mintah, S., Misefa, Y., Kusi-boateng, A., ... Mensah, F. B. (2014). Poverty Profile in Ghana (2005-2013), Ghana Living Standards Survey Round 6. Accra, Ghana.

Anaafo, D. (2015). Land reforms and land rights change: A case study of 
land stressed groups in the Nkoranza South Municipality, Ghana. Land Use Policy, 42, 538-546.

https://doi.org/10.1016/j.landusepol.2014.09.011

Antwi-Agyei, P., Dougill, A. J., \& Stringer, L. C. (2015). Impacts of land tenure arrangements on the adaptive capacity of marginalized groups: The case of Ghana's Ejura Sekyedumase and Bongo districts. Land Use Policy, 49, 203-212. https://doi.org/10.1016/j.landusepol.2015.08.007

Arko-Adjei, A. (2011). Adapting land administration to the institutional framework of customary tenure: The case of peri-urban Ghana. https://doi.org/978-1-60750-746-8

Arko-adjei, A., Jong, J. De, Zevenbergen, J., \& Tuladhar, A. (2009). Customary Land Tenure Dynamics at Peri-urban Ghana: Implications for Land Administration System Modeling. In FIG Working Week 2009 (p. 18).

Asiama, K., Bennett, R., \& Zevenbergen, J. (2017). Participatory Land Administration on Customary Lands: A Practical VGI Experiment in Nanton, Ghana. ISPRS International Journal of Geo-Information, 6(7). https://doi.org/10.3390/ijgi6070186

Asiama, K. O., Bennett, R. M., \& Zevenbergen, J. A. (2017). Land Consolidation on Ghana's Rural Customary Lands: Drawing from The Dutch, Lithuanian and Rwandan Experiences. Journal of Rural Studies (under Review), (November). https://doi.org/10.1016/j.jrurstud.2017.09.007

Asperen, P. V. a N., \& Mulolwa, A. (2006). Improvement of Customary Tenure Security as Pro-poor Tool for Land Development - A Zambian Case Study. In 5th FIG Regional Conference (pp. 1-15).

Asperen, P. van, \& Zevenbergen, J. (2007). Can Lessons Be Learnt From Improving Tenure Security in Informal Settlements? International Conference Sustainable Urban Areas, 15.

Azadi, H., \& Vanhaute, E. (2019). Mutual Effects of Land Distribution and Economic Development: Evidence from Asia, Africa, and Latin America. Land, 8(6), 96. https://doi.org/10.3390/land8060096

Ballard, T. J., Kepple, A. W., \& Cafiero, C. (2013). The Food Insecurity Experience Scale: Development of a Global Standard for Monitoring Hunger Worldwide.

Barry, M., \& Danso, E. K. (2014a). Tenure security, land registration and customary tenure in a peri-urban Accra community. Land Use Policy, 39, 358-365. https://doi.org/10.1016/j.landusepol.2014.01.017

Barry, M., \& Danso, E. K. (2014b). Tenure security, land registration and customary tenure in a peri-urban Accra community. Land Use Policy, 39, 358-365. https://doi.org/10.1016/j.landusepol.2014.01.017

Bassett, E. M. (2007). The persistence of the commons: Economic theory and community decision-making on land tenure in voi, Kenya. African Studies Quarterly, 9(3), 1-29.

Bentsi, E., \& Ankoma, L. (2018). Customary Law Review \& Institutional Mapping Report The Proforest Initiative The African Responsible Production and Sourcing Programme (ARPS). Retrieved from www.belonline.orgiiContents

Biederlack and Rivers. (2009). Comprehensive Food Security and Vulnerability Analysis (CFSVA). Retrieved from http://documents.wfp.org/stellent/groups/public/documents/ena/wfp20 
1820.pdf

Biitir, S.B., \& Nara, B. B. (2016). The role of Customary Land Secretariats in promoting good local land governance in Ghana. Land Use Policy, 50. https://doi.org/10.1016/j.landusepol.2015.10.024

Biitir, Samuel B., \& Nara, B. B. (2016). The role of Customary Land Secretariats in promoting good local land governance in Ghana. Land Use Policy, 50, 528-536. https://doi.org/10.1016/j.landusepol.2015.10.024

Biitir, Samuel B., Nara, B. B., \& Ameyaw, S. (2017). Integrating decentralised land administration systems with traditional land governance institutions in Ghana: Policy and praxis. Land Use Policy, 68(June), 402-414. https://doi.org/10.1016/j.landusepol.2017.08.007

Boudreaux, B. K., \& Sacks, D. (2009). Land tenure security and agricultural productivity.

Brasselle, A. S., Gaspart, F., \& Platteau, J. P. (2002). Land tenure security and investment incentives: Puzzling evidence from Burkina Faso. Journal of Development Economics, 67(2), 373-418. https://doi.org/10.1016/S0304-3878(01)00190-0

Brown, S. E., \& Justice, C. (2011). Criminology. To Improve the Academy, 29(1), xiii-xxii. https://doi.org/10.1002/j.2334-4822.2011.tb00614.x

Bugri, J. T. (2008). The dynamics of tenure security, agricultural production and environmental degradation in Africa: Evidence from stakeholders in north-east Ghana. Land Use Policy, 25(2), 271-285. https://doi.org/10.1016/j.landusepol.2007.08.002

Bugri, John Tiah. (2010). Understanding changing land access and use by the rural poor in Ghana.

Burge, S. (2015). An Overview of the Soft Systems Methodology. System Thinking: Approaches and Methodologies, 1-14. Retrieved from http://www.burgehugheswalsh.co.uk/Uploaded/1/Documents/SoftSystems-Methodology.pdf

Capaldo, J., Karfakis, P., Knowles, M., \& Smulders, M. (2010). A model of vulnerability to food insecurity (No. 10-03). ESA Working paper.

Capone, R., El Bilali, H., Debs, P., Cardone, G., \& Driouech, N. (2014). Food Economic Accessibility and Affordability in the Mediterranean Region: an Exploratory Assessment at Micro and Macro Levels. Journal of Food Security, 2(1), 1-12. https://doi.org/10.12691/jfs-2-1-1

Carte, L., Schmook, B., Radel, C., \& Johnson, R. (2019). The slow displacement of smallholder farming families: Land, hunger, and labor migration in Nicaragua and Guatemala. Land, 8(6). https://doi.org/10.3390/land8060089

Chauveau, Jean-Piere; Cissé, Salmana; Colin, Jean-Philippe; Cotula, Lorenzo; Delville, Philippe Lavigne; Neves, Bernardete; Quan, J. and T. (2007). Changes in " customary" land tenure systems in Africa Edited by Lorenzo Cotula. (Lorenzo Cotula, Ed.). IIED, FAO.

Chauvin, N. D., Mulangu, F., \& Porto, G. (2012). Food Production and Consumption Trends in Sub-Saharan Africa: Prospects for the Transformation of the Agricultural Sector. Working Papers 2012-11, (February), 76. https://doi.org/10.1016/j.foodpol.2013.10.006

Checkland, P., \& Poulter, J. (2010). Systems approaches to managing change: A practical guide. Systems Approaches to Managing Change: A Practical Guide. https://doi.org/10.1007/978-1-84882-809-4 
Chiaravalloti, R. M., Homewood, K., \& Erikson, K. (2017). Sustainability and Land tenure: Who owns the floodplain in the Pantanal, Brazil? Land Use Policy, 64, 511-524. https://doi.org/10.1016/j.landusepol.2017.03.005

Chigbu, U. E., \& Klaus, M. (2013). Insecurity - Generating System of Land Tenure and its Impact on Rural Development : Evidence from Uturu, Nigeria.

Chigbu, U., Paradza, G., \& Dachaga, W. (2019). Differentiations in Women's Land Tenure Experiences: Implications for Women's Land Access and Tenure Security in Sub-Saharan Africa. Land, 8(2), 22. https://doi.org/10.3390/land8020022

Chimhowu, A., \& Woodhouse, P. (2006). Customary Versus Private Property Rights? Dynamics and Trajectories of Vernacular Land Markets in SubSaharan Africa. Journal of Agrarian Change, 6(3), 346-371.

Choplin, A., \& Dessie, E. (2017). Titling the desert: Land formalization and tenure (in)security in Nouakchott (Mauritania). Habitat International, 64, 49-58. https://doi.org/10.1016/j.habitatint.2017.04.003

Christine, M., Simbizi, D., Zevenbergen, J., \& Bennett, R. (2015). Pro-Poor Land Administration and Land Tenure Security Provision. A Focus on Rwanda. GeoTechRwanda, 2014.

Conway, G. (2011). On Being a Smallholder. Conference on New Directions for Smallholder Agriculture, IFAD Rome, 24-25 January, 2011, 1-17.

Corsi, S., Marchisio, L. V., \& Orsi, L. (2017). Connecting smallholder farmers to local markets: Drivers of collective action, land tenure and food security in East Chad. Land Use Policy, 68(July 2016), 39-47. https://doi.org/10.1016/j.landusepol.2017.07.025

Cotula, L, \& Toulmin, C. (2004). Till to tiller: International migration, remittances and land rights in West Africa. International Institute for Environment and Development, 132(132), 1-92.

Cotula, L, Toulmin, C., \& Hesse, C. (2004). Land tenure and administration in Africa: Lessons of experience and emerging issues.

Cotula, L, Toulmin, C., Hesse, C., \& et al., C. (2004). Land tenure and administration in Africa: Lessons of experience and emerging issues, (January), 50.

Cotula, Lorenzo, \& Mathieu, P. (2008). Legal Empowerment in Practice: Using Legal Tools To Secure Land Rights in Africa. Environmental Law.

Cotula, Lorenzo, \& Neves, B. (2007). Changes in 'Customary' Land Tenure Systems in Africa. Changes in "customary" land tenure systems in Africa.

de Vries, W.T; Chigbu, E. . (2017). Responsible Land Management-Concept and application in a territorial rural context Verantwortungsvolles Landmanagement im Rahmen der Ländlichen Entwicklung.

Deininger, K., \& Jin, S. (2006). Tenure security and land-related investment: Evidence from Ethiopia. European Economic Review, 50(5), 1245-1277. https://doi.org/10.1016/j.euroecorev.2005.02.001

Dembitzer, B. (2014). Lorenzo Cotula: the great African land grab? Agricultural investment and the global food system: African arguments. Food Security, 6, 437-439. https://doi.org/10.1007/s12571-014-03473

Deng, X., Yan, Z., \& Xu, D. (2020). Agricultural Machinery Adoption : Empirical Analysis. Land.

Denzau, A. T. (2015). The Institutions and Economic Development in the 
OECD, (January 2007).

Doss, C., \& Meinzen-Dick, R. (2018). Women's Land Tenure Security: A Conceptual Framework, (January), 1-16.

du Plessis Jean, GLTN, UN-HABITAT, Augustinus Clarissa, Barry Michael, Lemmen Christiaan, R. L. (2016). THE CONTINUUM OF LAND RIGHTS APPROACH TO TENURE SECURITY : ADVANCES IN THEORY. Land and Poverty Conference 2016, 1-8.

Duncan, B. A., \& Brants, C. (2004). Access to and Control Over Land from a Gender Perspective. FAO Corporate Document Repository. Retrieved from http://www.fao.org/docrep/007/ae501e/ae501e00.htm

Economo, E., Hong, L., \& Page, S. E. (2016). Social structure, endogenous diversity, and collective accuracy. Journal of Economic Behavior and Organization, 125, 212-231. https://doi.org/10.1016/j.jebo.2016.01.003

Elliot, K., \& Wfp. (2012). Ghana Comprehensive Food Security \& Vulnerability Analysis 2010: Focus on Northern Ghana, Ministry of Food and Agriculture Ghana Statistical Service. Retrieved from http://documents.wfp.org/stellent/groups/public/documents/ena/wfp25 7009.pdf

Enemark, S. (2017). A Fit-For-Purpose approach to Land Administration in Africa in support of The 2030 Global Agenda (pp. 15-17).

Enemark, S., Bell, K. C., Lemmen, C., \& McLaren, R. (2014). Fit-For-Purpose Land Administration. International Federation of Surveyors (FIG). https://doi.org/https://www.fig.net/resources/publications/figpub/pub6 0/Figpub60.pdf

Enemark, S., \& Mclaren, R. (2017). FIT-FOR-PURPOSE LAND ADMINISTRATION : DEVELOPING COUNTRY SPECIFIC STRATEGIES FOR IMPLEMENTATION STIG ENEMARK Professor Emeritus of Land Management, Aalborg University , Denmark Director, Know Edge Ltd, UK Paper prepared for presentation at the " $2017 \mathrm{~W}$.

Fanzo, J. (2017). From big to small: the significance of smallholder farms in the global food system. The Lancet Planetary Health, 1(1), e15-e16. https://doi.org/10.1016/S2542-5196(17)30011-6

FAO, IFAD, UNICEF, WFP, W. (2018). The State of Food Security and Nutrition in the World 2018. Building climate resilience for food security and nutrition. https://doi.org/10.1093/cjres/rst006

FAO. (2014). Towards stronger family farms. Towards Stronger Family Farms Voices in the International Year of the Family Farm. . Edited by Janneke Bruil (ILEIA), 39. Retrieved from http://www.fao.org/3/a-i4171e.pdf? FAO, 2014

FAO. (2015). Regional Overview of Food Insecurity Africa. Strategic Survey (Vol. 0). https://doi.org/10.1080/04597238908460834

FAO. (2019). Food Security and Nutrition in the World. IEEE Journal of Selected Topics in Applied Earth Observations and Remote Sensing. https://doi.org/10.1109/JSTARS.2014.2300145

FAO IFAD UNICEF, W. \& W. (2017). The State of Food Security and Nutrition in the World. Fao. Retrieved from http://www.fao.org/state-of-foodsecurity-nutrition/en/

FAO, IFAD, \& WFP. (2015). The State of Food Insecurity in the World: Meeting the 2015 international hunger targets: taking stock of uneven progress. FAO, IFAD and WFP. https://doi.org/I4646E/1/05.15 
Farasat, A., \& Nikolaev, A. G. (2016). Social structure optimization in team formation. Computers and Operations Research, 74, 127-142. https://doi.org/10.1016/j.cor.2016.04.028

Federal Ministry of Food and Agriculture (BMLE). (2015). Understanding global food security and nutrition Facts and backgrounds, 29. Retrieved from www.bmel.de/publikationen\%0AThis

Ferrini, L. (2012). The Importance of Institutions to Economic Development. E-International Relations, 1-5.

Food and Agriculture Organization. (2002). Land Tenure and Rural Development. FAO land tenure studies, . https://doi.org/9251048460

Forbus, K. D. (2008). Chapter 9 Qualitative Modeling. In F. van Harmelen, V. Lifschitz, \& B. Porter (Eds.), Foundations of Artificial Intelligence (Vol. 3, pp. 361-393). Elsevier B.V. https://doi.org/10.1016/S15746526(07)03009-X

Form, W. A. (1954). The place of social structure in the determination of land use: some implications for a theory of urban ecology. Social Forces, Oxford University Press, 32(4), 317-323.

Fosudo, O. P. (2014). Land Tenure Regularisation in Rwanda: the outcome for agricultural land use change in peri-urban Kigali.

Galvagno, M., \& Dalli, D. (2014). Theory of value co-creation: A systematic literature review. Managing Service Quality, 24(6), 643-683. https://doi.org/10.1108/MSQ-09-2013-0187

Gazdar, H., Khan, A., \& Khan, T. (2002). Land Tenure, Rural Livelihoods and institutional innovation.

Gebrehiwot, T. (2012). Food Security Policy : Does It Work? Does It Help?

Ghebru, H., \& Lambrecht, I. (2017). Drivers of perceived land tenure (in)security: Empirical evidence from Ghana. Land Use Policy, 66(July 2016), 293-303. https://doi.org/10.1016/j.landusepol.2017.04.042

Gifford, J., Fiona, N., \& George, L. (2005). Employee Involvement Information, Consultation and Discretion, 1-111.

Godwin Djokoto and Opoku Kyeretwie. (2010). Land tenure in Ghana: Making a case for incorporation of customary law in land administration and areas of intervention by the growing forest partnership. International Union for the Conservation of Nature and Growing Forest Partnerships, 34.

Goldschmidt, W. (1978). Large-scale farming and the rural social structure.

Gollin, D. (2014). Smallholder agriculture in Africa. IIED Working Paper. IIED, London.

GREEN, R. -J, \& HERGET, M. (1991). Outcomes of Systemic/Strategic Team Consultation: III. The Importance of Therapist Warmth and Active Structuring. Family Process, 30(3), 321-336. https://doi.org/10.1111/j.1545-5300.1991.00321.x

Group, W. B. (2016). Structural Transformation of Moldovan Smallholder Agriculture: Implications for Poverty Reduction and Shared Prosperity.

GSS. (2012). :: Ghana Statical Service : : Retrieved from http://www.statsghana.gov.gh/pop_stats.html

Gyamera, E. (2018). Land Acquisition in Ghana; Dealing with the Challenges and the Way Forward ., (January).

Hancock, B., Ockleford, E., \& Windridge, K. (2009). An Introduction to Qualitative Research. The NIHR Research Design Service for Yorkshire \& the Humber. Retrieved from https://www.rds-yh.nihr.ac.uk/wp- 
content/uploads/2013/05/5_Introduction-to-qualitative-research2009.pdf

Ho, P. (2001). Who Owns China 's Land? Policies, Property Rights and Deliberate Institutional Ambiguity. The China Quarterly, 166(166), 394421.

Holden, S. T., \& Ghebru, H. (2016). Land tenure reforms, tenure security and food security in poor agrarian economies: Causal linkages and research gaps. Global Food Security, 10, 21-28. https://doi.org/10.1016/j.gfs.2016.07.002

IFAD. (2009). Smallholder farming in transforming economies of Asia and the Pacific: Challenges and Opportunities. Occasional Papers by IFAD, 1-30. Retrieved from http://www.ifad.org/events/gc/33/roundtables/pl/pi_bg_e.pdf

Ind, N., \& Coates, N. (2013). The meanings of co-creation. European Business Review, 25(1), 86-95. https://doi.org/10.1108/09555341311287754

International Fund for Agricultural Development. (2015). Land tenure security.

International Organisation for Migration. (2018). World Migration Report. World Migration Report. https://doi.org/10.1017/CBO9781107415324.004

Jacob, J.-P., Delville, P. L., Le Meur, P.-Y., \& International Institute for Environment and Development. (2006). Changes in land access and governance in West Africa: markets, social mediations and public policies, (April), 85.

Johnson, D. R. (2007). Reflections on the Bundle of Rights. Vermont Law Review, 32, 247.

Kamwi, J., Cho, M., Kaetsch, C., Manda, S., Graz, F., \& Chirwa, P. (2018). Assessing the Spatial Drivers of Land Use and Land Cover Change in the Protected and Communal Areas of the Zambezi Region, Namibia. Land, 7(4), 131. https://doi.org/10.3390/land7040131

Karia, A. O., \& Omari, S. (2017). Importance of Compensation and Benefits on Performance of Public Water Utilities in Tanzania Importance of Compensation and Benefits on Performance of Public Water. Afrian Journal of Business Management, (January 2015), 9-18.

Kasanga, K., \& Kotey, N. A. (2001). Land Management in Ghana: Building on Tradition and Modernity. Russell The Journal Of The Bertrand Russell Archives, (February), 1-42. https://doi.org/ISBN: 1-899825-69-X

Kaulio, M.A. and Karlsson, I. C. (1998). Triangulation strategies in user requirements investigations: a case study on the development of an ITmediated service. Behaviour \& Information Technology, Vol. 17(No. 2), 103-112.

Kelkar, G. (2014). THE FOG OF ENTITLEMENT : WOMEN AND LAND IN INDIA. Economic and Political Weekly, (November).

Kidido, J. K., Bugri, J. T., \& Kasanga, R. K. (2017). Dynamics of youth access to agricultural land under the customary tenure regime in the Techiman traditional area of Ghana. Land Use Policy, 60, 254-266. https://doi.org/10.1016/j.landusepol.2016.10.040

Knight, R. S. (2010). Statutory recognition of customary land rights in Africa An investigation into best practices for lawmaking and implementation. Rome. 
Kothari, C., Kumar, R., \& Uusitalo, O. (2014). Research Methodology. New Age International. https://doi.org/http://196.29.172.66:8080/jspui/bitstream/123456789/ 2574/1/Research\%20Methodology.pdf

Kumar, M. S. (2013). A SYSTEMS APPROACH FOR PROVIDING LEGAL AID FOR LAND. In Annual World Bank Conference on Land and Poverty; Washington DC, April 8-11, 2013.

Kuuire, V. Z., Mkandawire, P., Luginaah, I., \& Arku, G. (2016). Abandoning land in search of farms: challenges of subsistence migrant farming in Ghana. Agriculture and Human Values, 33(2), 475-488. https://doi.org/10.1007/s10460-015-9612-0

Kuzmanova, M., \& Alexandrova, M. (2017). Change Management and Project Management Integration. Leadership \& Management: Integrated Politics of Research and Innovations LIMEN, (December 14), 204-212.

Retrieved from

https://www.researchgate.net/publication/323935063_Change_Manage ment_and_Project_Management_Integration_Survey_Evidence

Kyeyune, $\bar{V}$., \& Turner, $\bar{S}$. (2016). Yielding to high yields? Critiquing food security definitions and policy implications for ethnic minority livelihoods in upland Vietnam. Geoforum, 71, 33-43. https://doi.org/10.1016/j.geoforum.2016.03.001

Lambrecht, I., \& Asare, S. (2016). The complexity of local tenure systems: A smallholders' perspective on tenure in Ghana. Land Use Policy, 58, 251263. https://doi.org/10.1016/j.landusepol.2016.07.029

Lamont, J. (1994). Depressed mood and power over the feelings of other persons. Journal of Clinical Psychology, 29(3), 319-321. https://doi.org/10.1002/1097-4679(197307)29:3<319::AIDJCLP2270290311>3.0.CO;2-D

Landesa Rural Development Institute. (2016). Ghana: Gender and the Land Access and Tenure Security Project.

Lawry, S., Samii, C., Hall, R., Leopold, A., Hornby, D., Mtero, F., ... Samii, C. (2014). The impact of land property rights interventions on investment and agricultural productivity in developing countries. https://doi.org/10.4073/csr.2014.1

Learch, J. A. and C. (2016). National Survey and Segmentation of Smallholder Households in Mozambique.

Lemmen, C. (2013). The Social Tenure Domain Model The Social Tenure Domain Model Pro-Poor. Fig Report, (52), 18.

Lemmen, C., Augustinus, C., Plessis, J. D. U., Laarakker, P., Zeeuw, K. D. E., Saers, P., \& Molendijk, M. (2015). The Operationalisation Of The ' Continuum of Land Rights ' at Country Level. World Bank Conference on Land and Poverty, (July).

Lengoiboni, M., Richter, C., \& Zevenbergen, J. (2019). Cross-cutting challenges to innovation in land tenure documentation. Land Use Policy, 85(March), 21-32. https://doi.org/10.1016/j.landusepol.2019.03.023

Lentz, C. (2001). Contested boundaries: decentralisation and land conflicts in northwestern Ghana. Bulletin de I'APAD.

Lipton, M., \& Saghai, Y. (2017). Food security , farmland access ethics, and land reform. Global Food Security, 12(March 2016), 59-66. https://doi.org/10.1016/j.gfs.2016.03.004

Lovendal, C. R., \& Knowles, M. (2006). Tomorrow's Hunger A Framework 
for Analysing Vulnerability to Food Security. Development, 3. https://doi.org/10.1093/acprof

Lund, C. (2000). African land tenure: Questioning basic assumptions. Drylands Issue Papers, 28.

Lynn, G. (2015). The Effect of Vision and Role Clarity on Team Performance. Pressacademia, 4(3), 473-473. https://doi.org/10.17261/pressacademia.2015313067

Ma, X. (2013). Does Tenure Security Matter? -Rural Household Responses to Land Tenure Reforms in Northwest China. Retrieved from http://edepot.wur.nl/281615

Mabaso, C. M., \& Dlamini, B. I. (2017). Impact of Compensation and Benefits on Job Satisfaction. Research Journal of Business Management, 11(2), 80-90. https://doi.org/10.3923/rjbm.2017.80.90

Maqsood, T., Finegan, A. D., \& Walker, D. H. T. (2009). Five case studies applying Soft Systems Methodology to Knowledge Management. 7th Annual Conference on Systems Engineering Research, 18.

Martinez, J. (2017). Working with the Grain: How Amenable to Digital Transformation Are the Monitoring and Repair of Rural Water Points in Tanzania? Information Technologies and International Development, 13(2017), 103-121.

Maxwell, D., \& Wiebe, K. (1999). Land Tenure and Food Security: Exploring dynamic linkages. Development and Change, 30, 825-849. https://doi.org/10.1111/1467-7660.00139

Mennonite Economic Development Associates (MEDA) Ghana. (2012). The Ghana Food Security Research with a Focus on the Upper West Region (Vol. 2012).

Meyer, C. B. (2001). A Case in Case Study Methodology. Sage Publications, Vol. 13(No. 4.), 329-352. Retrieved from http://citeseerx.ist.psu.edu/viewdoc/download?doi=10.1.1.461.5170\&re $\mathrm{p}=$ rep 1 \&type $=p d f$

Ministry of Food and Agriculture. (2011). Agriculture in Ghana: Facts and figures (2010).

Mireku, K. O., Kuusaana, E. D., \& Kidido, J. K. (2016). Legal implications of allocation papers in land transactions in Ghana-A case study of the Kumasi traditional area. Land Use Policy, 50. https://doi.org/10.1016/j.landusepol.2015.09.015

Mizero, M., Karangwa, A., Burny, P., Michel, B., \& Lebailly, P. (2018). Agrarian and land reforms in Rwanda: Situation and perspectives. Agris On-Line Papers in Economics and Informatics, 10(3), 79-92. https://doi.org/10.7160/aol.2018.100307

Morton, J. F. (2007). The impact of climate change on smallholder and subsistence agriculture. Proceedings of the National Academy of Sciences of the United States of America, 104(50), 19680-19685. https://doi.org/10.1073/pnas.0701855104

Mullan, K., Grosjean, P., \& Kontoleon, A. (2011). Land tenure arrangements and rural-urban migration in China. World Development, 39(1), 123133. https://doi.org/10.1016/j.worlddev.2010.08.009

Mulolwa, A. (2002). Appropriate Tenure Model for Sub-Saharan Africa.

Munassar, F., Ghanim, A., \& Ahmad Dahlan, A. R. (2013). Change Management and its contribution to the success of IT project implementation. International Journal of Information and 
Communication Technology Research, 3(4), 134-140.

Mwesigye, F., Matsumoto, T., \& Otsuka, K. (2017). Population pressure, rural-to-rural migration and evolution of land tenure institutions: The case of Uganda. Land Use Policy, 65, 1-14. https://doi.org/10.1016/j.landusepol.2017.03.020

Myers Gregory, F. M. (2013). Land Tenure and Property Rights Framework (Vol. 1).

Naab, F. Z., Dinye, R. D., \& Kasanga, R. K. (2013). Urbanisation and its impact on agricultural lands in growing cities in developing countries: a case study of Tamale in Ghana. Modern Social Science Journal, 2(2), 256-287. Retrieved from http://scik.org/index.php/mssj/article/view/993

NAMATI Innovations in legal empowerment, \& Institute, L. R. D. (2015). Recommendations for Implementation of Pro-Poor Land Policy and Land Law in Myanmar: National Data and Regional Practices.

Napoli, M., de Muro, P., \& Mazziota, M. (2015). Towards a Food Insecurity Multidimensional Index, 1-72. https://doi.org/10.1016/j.enconman.2012.03.002

Nara, B. Baslyd, Lengoiboni, M., \& Zevenbergen, J. (2020a). Implications of Customary Land Rights Inequalities for Food Security: A Study of Smallholder Farmers in Northwest Ghana. Land.

Nara, B. Baslyd, Lengoiboni, M., \& Zevenbergen, J. (2020b). Infuences of Community Land Rights and Tenure Security Intervention Processes on Food Security in Northwest Ghana. In W. T. De Vries, J. T. Bugri, \& F. Mandhu (Eds.), Responsible and Smart Land Management Interventions An African Context (1st ed., pp. 49-62). Boca Raton: Taylor \& Francis Group.

Nara, Baslyd B., Lengoiboni, M., \& Zevenbergen, J. (2021). Assessing customary land rights and tenure security variations of smallholder farmers in northwest Ghana. Land Use Policy, 104, 105352. https://doi.org/10.1016/j.landusepol.2021.105352

Nara, Baslyd Begerr, Mwingyine, D. T., Boamah, N. A., \& Biitir, S. B. (2014). Enhancing Efficiency in Land Management through the Customary Land Secretariats ( CLSs ) in Upper West Region, Ghana, 4(1), 24-31.

Nguyen, H. (2014). Farmers' land tenure security in Vietnam and China. Retrieved from https://www.rug.nl/research/portal/files/14332380/Complete_dissertati on.pdf

Nguyen, T. H. T., Tran, V. T., Bui, Q. T., Man, Q. H., \& Walter, T. de V. (2016). Socio-economic effects of agricultural land conversion for urban development: Case study of Hanoi, Vietnam. Land Use Policy, 54, 583592. https://doi.org/10.1016/j.landusepol.2016.02.032

Nkegbe, P. K., Abu, B. M., \& Issahaku, H. (2017). Food security in the Savannah Accelerated Development Authority Zone of Ghana: An ordered probit with household hunger scale approach. Agriculture and Food Security, 6(1), 1-11. https://doi.org/10.1186/s40066-017-0111-y

Nyarko, J. (2015). Media Independence in Ghana: The Case of the Fourth Republic. Journal of Chemical Information and Modeling. https://doi.org/10.1017/CBO9781107415324.004

Obeng-Odoom, F. (2012). Land reforms in Africa: Theory, practice, and outcome. Habitat International, 36(1), 161-170. 
https://doi.org/10.1016/j.habitatint.2011.07.001

Ostrom, B., \& Hanson, R. (2010). Achieving High Performance : A Framework for Courts.

Payne, G; Durand-lasserve, A. (2012). " Holding On : Security of Tenure Types, Policies, Practices and Challenges" Research Paper prepared for the Special Rapporteur on adequate housing as a component of the right to an adequate standard of living, inform her Study on Security of Tenure.

Payne, G. (2004). Land tenure and property rights: An introduction. Habitat International, 28(2), 167-179. https://doi.org/10.1016/S01973975(03)00066-3

Peters, P. E. (1997). Challenges in Land Tenure and Land Reform in Africa: An Anthropological Perspective (Vol. 1574).

Peters, P. E. (2009). Challenges in Land Tenure and Land Reform in Africa: Anthropological Contributions. World Development, 37(8), 1317-1325. https://doi.org/10.1016/j.worlddev.2008.08.021

Peters, P. E. (2013a). Conflicts over land and threats to customary tenure in africa. African Affairs, 112(449), 543-562. https://doi.org/10.1093/afraf/adt047

Peters, P. E. (2013b). Land appropriation, surplus people and a battle over visions of agrarian futures in Africa. Journal of Peasant Studies, 40(3), 537-562. https://doi.org/10.1080/03066150.2013.803070

Pinstrup-Andersen, P. (2009). Food security: definition and measurement. Food Security, 1(1), 5-7. https://doi.org/10.1007/s12571-008-0002-y

Place, F. (2009). Land Tenure and Agricultural Productivity in Africa: A Comparative Analysis of the Economics Literature and Recent Policy Strategies and Reforms. World Development, 37(8), 1326-1336. https://doi.org/10.1016/j.worlddev.2008.08.020

Platteau, J. P. (1996). The Evolutionary Theory of Land Rights as Applied to Sub-Saharan Africa: A Critical Assessment. Development and Change, 27, 29-86. https://doi.org/10.1111/j.1467-7660.1996.tb00578.x

Pottier, J. (2005). 'Customary Land Tenure' in Sub-Saharan Africa Today: Meanings and contexts. From the Ground up: Land Rights, Conflict and Peace in Sub-Saharan Africa, 55-75.

Quamrul, A., \& Oded, G. (2008). Malthusian Population Dynamics: Theory and Evidence. Working Papers.

Quan, J. F., \& Geoffrey, P. (2008). Secure Land Rights for All GLTN contributes to the implementation. Gltn. Retrieved from www.unhabitat.org

Quan, J., \& Toulmin, C. (2004). Formalising and Securing Land Rights in Africa. Overview paper, 1-13.

Rao, F., Spoor, M., Ma, X., \& Shi, X. (2016). Land tenure (in)security and crop-tree intercropping in rural Xinjiang, China. Land Use Policy, 50, 102-114. https://doi.org/10.1016/j.landusepol.2015.09.001

Reiter, B. (2017). Theory and Methodology of Exploratory Social Science Research. Ijsrm, 5(4), 129-150. Retrieved from http://scholarcommons.usf.edu/gia_facpubhttp://scholarcommons.usf.e du/gia_facpub/132www.ijsrm.humanjournals.com

Renée, G., Richardson, A., \& Elisa, S. (2016). GENDER \& COLLECTIVELY HELD LAND.

Republic of Ghana. (2012). Population and Housing Census Report, 2010. 
Retrieved from

http://www.statsghana.gov.gh/docfiles/2010phc/Census2010_Summary _report_of_final_results.pdf

Republic of Ghana. (2014). Ghana Living Standards Survey Round 6 (GLSS 6). Accra. Retrieved from http://www.statsghana.gov.gh/docfiles/glss6/GLSS6_Main Report.pdf

Riesgo, L., Louhichi, K., Gomez y Paloma, S., Hazell, P., Ricker-Gilbert, J., Wiggins, S., ... Mishra, A. K. (2016). Food and nutrition security and role of smallholder farms: challenges and opportunities. Workshop Proceedings. https://doi.org/10.2791/653314

Ruerd, R., \& Policy and Operations Evaluation Department (IOB) Ministry of Foreign Affairs. (2011). Improving food security. A systematic review of the impact of interventions in agricultural production, value chains, market regulation, and land security. The Hague, The Netherlands. Retrieved from www.minbuza.nl \%7C www.rijksoverheid.nl

Rykiel, E. J., Thacker, B. H., Doebling, S. W., Hemez, F. M., Anderson, M. C., Pepin, J. E., ... Sargent, R. G. (2011). Testing ecological models: The meaning of validation. Proceedings of the 2011 Winter Simulation Conference, 90(October), 41. https://doi.org/10.1016/03043800(95)00152-2

Samberg, L. H., Gerber, J. S., Ramankutty, N., Herrero, M., \& West, P. C. (2016). Subnational distribution of average farm size and smallholder contributions to global food production. Environmental Research Letters, 11(12). https://doi.org/10.1088/1748-9326/11/12/124010

Sanga, R. (2009). Assessing the impact of customary land rights registration on credit access by farmers in Tanzania: A case study in Mbozi district. International Institute for Geo-Information Science and .... Retrieved from http://www.itc.nl/library/papers_2009/msc/gimla/sanga.pdf

Savenije, H., Baltissen, G., Van Ruijven, M., Verkuijl, H., Hazelzet, M., \& Van Dijk, K. (2017). Improving the positive impacts of investments on smallholder livelihoods and the landscapes they live in Improving the positive impacts of investments on smallholder livelihoods and the landscapes they live in 2 Disclaimer.

Sietchiping, R., Aubrey, D., Bazoglu, N., Augustinus, C., \& Mboup, G. (2012). MONITORING TENURE SECURITY WITHIN THE CONTINUUM OF LAND RIGHTS: METHODS AND PRACTICES Monitoring security of tenure within the continuum of land rights: Methods and practices. Retrieved from http://www.landandpoverty.com/agenda/pdfs/paper/sietchiping_full_pa per.pdf

Simbizi, D. M. C. (2016). Measuring land tenure security: a pro-poor perspective. https://doi.org/10.3990/1.9789036540544

Simbizi, M. C. D., Bennett, R. M., \& Zevenbergen, J. (2014). Land tenure security: Revisiting and refining the concept for Sub-Saharan Africa's rural poor. Land Use Policy, 36, 231-238. https://doi.org/10.1016/j.landusepol.2013.08.006

Simonsen, J. (1994). Soft Systems Methodology. Retrieved from http://www.jespersimonsen.dk/Downloads/SSM-IntroductionJS.pdf

Singirankabo, U. A., \& Ertsen, M. W. (2020). Relations between land tenure security and agricultural productivity: Exploring the effect of land registration. Land, 9(5). https://doi.org/10.3390/LAND9050138 
Sinitsina, I. (2019). African Legal Tradition: J.M.Sarbah, J.B.Danquah, N.A.Ollennu, 9(3), 142-153.

Songsore, J. (2009). The Urban Transition in Ghana: Urbanization, National Development and Poverty Reduction. Africa, 1-71. Retrieved from http://pubs.iied.org/pubs/pdfs/G02540.pdf

Srikanth, P. B., \& Jomon, M. G. (2013). Role ambiguity and role performance effectiveness: Moderating the effect of feedback seeking behaviour. Asian Academy of Management Journal, 18(2), 105-127.

Sumbu, C., Handledare, T., \& Stigbrand, K. (2013). Media freedom in Ghana, $1-49$.

Swensson, L. F. J., \& Tartanac, F. (2020). Public food procurement for sustainable diets and food systems: The role of the regulatory framework. Global Food Security, 25(March), 100366. https://doi.org/10.1016/j.gfs.2020.100366

Swigert, V. L., \& Farrell, R. A. (1980). Speedy trial and the legal process. Law and Human Behavior, 4(3), 135-145. https://doi.org/10.1007/BF01040316

Tapia, C. (2004). Land reform in Namibia: Economic versus Socio-political Rationale. Land Reform, Land Settlement and Cooperratives, (January 2004).

Tirole, J. (1989). The Theory of Social Structure. Industrial Organization, MIT Press, Cambridge. Viswasrao, Sharmila (Vol. 78).

Toulmin, C. (2008). Securing land and property rights in sub-Saharan Africa: The role of local institutions. Land Use Policy, 26(1), 10-19. https://doi.org/10.1016/j.landusepol.2008.07.006

Jean-Pierre Chauveau, Salmana Cisse, Jean-Philippe Colin, Lorenzo Cotula, Philippe Lavigne Delville, Bernardetes Neves and Julian Quan \& Camilla Toulmin (2006). Changes in "customary" land tenure systems in Africa. (Access to Natural Resource Sub-Programme No. 38). (Lorenzo Cotula, Ed.). Dlonguebougou, Mali: FAO.

Tsioptsias, N., Tako, A., \& Robinson, S. (2016). Model validation and testing in simulation: A literature review. OpenAccess Series in Informatics, 50(6), 6.1-6.11. https://doi.org/10.4230/OASIcs.SCOR.2016.6

Ubink, J. (2018). Customary Legal Empowerment in Namibia and Ghana? Lessons about Access, Power and Participation in Non-state Justice Systems. Development and Change, 49(4), 930-950. https://doi.org/10.1111/dech.12415

United Nations Settlement Programme. (2004). NAIROBI URBAN SECTOR PROFILE.

United States Agency for International Development (USAID). (2016). Land tenure and food security. African Agrarian Systems.

USAID COUNTRY PROFILE. (n.d.). Retrieved from https://usaidlandtenure.net/wpcontent/uploads/2016/09/USAID_Peru_Country_Profile_FinalForClearan ce_10-14-16.pdf

Uwayezu, E., \& de Vries, W. (2018). Indicators for Measuring Spatial Justice and Land Tenure Security for Poor and Low Income Urban Dwellers. Land, 7(3), 84. https://doi.org/10.3390/land7030084

Van Gelder, J.-L., \& Luciano, E. C. (2015). Tenure security as a predictor of housing investment in low-income settlements: testing a tripartite model. Environment and Planning A Field United Nations Habitat, 47, 
485-500. https://doi.org/10.1068/a130151p

Van Vliet, J. A., Schut, A. G. T., Reidsma, P., Descheemaeker, K., Slingerland, M., Van de Ven, G. W. J., \& Giller, K. E. (2015). Demystifying family farming: Features, diversity and trends across the globe. Global Food Security, 5, 11-18. https://doi.org/10.1016/j.gfs.2015.03.001

Wegerif, M. C. ., \& Guerena, A. (2020). Land Inequality Trends and Drivers. Land, 1-23.

Wehrmann, B. (2008). GTZ_land_conflicts manual-Book.

Wehrmann, B. (2017). Understanding, preventing and solving land conflicts, 1-156.

Weißleder, S., \& Lackner, H. (2013). Top-Down and Bottom-Up Approach for Model-Based Testing of Product Lines. Electronic Proceedings in Theoretical Computer Science, 111(Mbt), 82-94. https://doi.org/10.4204/eptcs.111.7

Wickeri, Elisabeth and Kalhan, A. (2010). Land Rights Issues in International Human Rights Law, 4, 10.

Williamson, I., Enemark, S., Wallace, J., \& Rajabifard, A. (2010). Land Administration for Sustainable Development. paper presented to FIG Congress 2010 Facing the Challenges - Building the Capacity, Sydney, Australia, 11-16 April 2010. Retrieved from https://www.fig.net/pub/fig2010/papers/ts03a/ts03a_williamson_enem ark_et_al_4103.pdf

Yadav, M., \& Rangnekar, S. (2015). Service Quality from the Lenses of Role Clarity and Organizational Itizenship Behavior. Procedia - Social and Behavioral Sciences, 189, 395-405. https://doi.org/10.1016/j.sbspro.2015.03.236

Yaro, J. A. (2010). Customary tenure systems under siege: Contemporary access to land in Northern Ghana. GeoJournal, 75(2), 199-214. https://doi.org/10.1007/s10708-009-9301-x

Yin, R. K. (2003). Case Study Research Design and Methods.

Zainal, Z. (2007). Case study as a research method. Jurnal Kemanusiaan Bil, 9. Retrieved from http://psyking.net/htmlobj3837/case_study_as_a_research_method.pdf

Zant, W. (2005). What makes Smallholders move out of Subsistence Farming: Is Access to Cash Crop Markets going to do the Trick? Ipd.Gu.Se, 1-55. Retrieved from http://www.ipd.gu.se/digitalAssets/1373/1373642_zant.pdf

Zevenbergen, Jaap; De Vries, Walter; Bennet, R. (2016). Advances in responsible land administration. Journal of Spatial Science (Vol. 61). https://doi.org/10.1080/14498596.2016.1145619

Zevenbergen, J. (2002a). A Systems Approach to Land Registration and Cadastre. Retrieved from http://www.geo.tudelft.nl/gigb/

Zevenbergen, J. (2002b). Systems of Land Registration, Aspects and Effects. Nederlandse Commissie voor Geodesie Netherlands Geodetic Commission, PhD.

Zevenbergen, J., Augustinus, C., Antonio, D., \& Bennett, R. (2013). Pro-poor land administration: Principles for recording the land rights of the underrepresented. Land Use Policy, 31(March), 595-604. https://doi.org/10.1016/j.landusepol.2012.09.005

Zevenbergen, J., De Vries, W., \& Bennett, R. (2015). Advances in responsible 
land administration. https://doi.org/https://doi.org/10.1201/b18988 


\section{Summary}

\section{Summary}

Land rights in Ghana emanate from the customary land tenure system. Secure land rights encourage access to and maintenance of large farm sizes and their productive use among others. This tenure security provides some confidence for farmers to increase farm investments and an assurance that they will benefit from those investments. This consequently increases farm produce thereby promoting food security due to food availability. Meanwhile, external pressure from population growth, urbanisation and general economic development can overwhelm the internal structures of the customary land tenure and service arrangements for safeguarding people's land rights. These arrangements are usually non-monetary 'homages' in the form of gifts or labour, which non-member landholders are required to seasonally render to landowners to acknowledge the landowners' ownership rights and renew such landholders' secondary rights and secure the land tenure. Governments' efforts in the past to promote food security by strengthening land rights and securing land tenure have largely been based on 'imported' policies of formalisation, registration or documentation processes. These efforts took little or no consideration of local customary views, practices or land tenure dynamics. As a result, the expected benefits of these efforts were either non-existent or barely minimal, not encouraging thus making them unsuccessful. Therefore, this thesis suggests a more pragmatic approach - to work with local people to co-create (or co-design) a responsible and fit-for-purpose customary land rights/tenure and food security model. This involves local people first assessing their own local land laws and practices. Then, they learn from successful models from external environments and co-create a new model by blending the strengths of both so that it fits their local needs and environment.

The first objective of this thesis assessed the changing customary land rights and tenure security inequalities and their implications for food security of subsistence farmers in northwest Ghana. Using the social structure theory, the study was carried out through in-depth interviews of identified categories of smallholder farmers - disabled, women, men and middle-aged and youth. The specific land rights and tenure security of each group were identified and examined. Thereafter, the implications were also examined of the different groups. The outcome was that there are indeed marked inequalities where male landowners possess the strongest land rights with the highest land tenure security. Then, females from the landowning group who are placed higher on the communities' social structure possess similarly weak land rights and low land tenure security just like their female settler counterparts. Paradoxically, even though male settlers are lower on the social structure, they were found to possess stronger land rights and higher land tenure security than females from the landowning group. Implying that masculinity and femininity determine the nature of people's land rights and tenure security in the study area more than any other factor. For instance, disability does not significantly affect people's land rights as much as their sex/gender does. Therefore, there exists more food insecurity challenges in terms of availability and accessibility among all females and male settlers possessing weaker land rights than male landowners whose land rights are stronger. Of course, females from the 
landowning group benefit marginally for their membership among landowners than their counterparts who are females and at the same time settlers. The study concluded that there is the need to put strategies towards narrowing land rights and tenure security inequality gaps. This will stimulate increased investments from all categories of farmers to acquire, possess and maintain sizeable lands, increase investment on those lands more productively for increased farm produce. This may result in food availability among the people which can stimulate their food accessibility and thereby promoting nutrition and food stability as well.

The second objective ascertained how the challenges of the changing customary tenure and service arrangements of subsistence farmers can be tackled to strengthen land rights, improve tenure security and consequently, food security. In this objective, the study examined the influences of community land rights and tenure security intervention processes on food security in Northwest Ghana. The local land tenure model and its inherent challenges hindering the realisation of their human aspirations of secure land tenure and food security were examined. The challenges basically were about the absence of an overarching legislation, more robust information flow system, low media involvement in terms of communication and lack of intervention opportunities for members to address land rights challenges thereby also affecting their farming, food availability and consequently food security. By working with local communities, its members' suggested strategies (both local and external) that need to be put in place to address these challenges. The strategies include maintaining the local land rights model and blending it with some aspects suggested in literature. The first is an overarching legislation to give legal effect to processes in the local land rights model. This was initially absent. Second is to encourage information flow and regular communication about land rights issues with media empowerment and active involvement of local, mainstream as well as social media to quickly draw attention and call for prompt action by the responsible institutions. Then legal intervention by legal advocates and paralegals is needed to facilitate poor farmers' access to the formal court system for justice whenever the customary approach is unable to provide them with satisfactory resolution to their land rights and land tenure challenges.

Sub-objective three was to co-create the design of a new model for improving tenure security and food security of subsistence and smallholder farmers in customary areas in the region. Therefore, based on the outcome from objectives one and two, the third objective was to ascertain how challenges of customary tenure and service arrangements of subsistence farmers can be resolved towards improving tenure security and food security. The study at this stage worked with the local people and co-created a land tenure model referred to as responsible and fit-for-purpose (FFP) because it emanates from the people and took local practices, customs and ideas in the design of the model. By the nature of this new model, all customary land rights and land tenure issues are encapsulated in and guided by the overarching legislation. What this means is that every aspect of local tenure will now be legally enforceable when the new overarching legislation is implemented after passing a test implementation stage in sub-objective four to confirm its potential feasibility on the ground. 
Sub-objective four was to test the implementation of the new responsible and FFP model towards increasing tenure security for all categories of subsistence and smallholder farmers to enhance farming, possibly increase farm produce, food availability and consequently improve food security. In testing the model, various representatives of the studied communities mock-acted in various roleplay sessions. During this exercise, land rights issues, challenges and disagreements were presented. Some of the local people acted as institutions and individuals responsible for addressing the issues. In the process, some matters were quickly resolved while others were referred to the next level of authority as contained in the model until it was resolved. All aspects of the model - court, legal advocates, media etc. were tested and passed as implementable and potentially effective for strengthening land rights and for securing customary land tenure. The almost unanimous acceptance and success rating were captured in a Likert scale with four and two communities agreeing and strongly agreeing respectively.

In conclusion therefore, strong customary land rights and secure customary land tenure are important prerequisites for subsistence and smallholder farmers to invest their time, money and effort in farming with a high possibility of increasing food produced from their farms and therefore promoting food security. Of course, other conditions like favourable rainfall, absence of pests, fertile soil and fertilizer application to mention a few must not be overlooked in the process of achieving food security through strong land rights and secure land tenure. This thesis contributes to knowledge and literature with the addition of empirical evidence about subsistence and smallholder farmers' land rights, land tenure and food security issues in the context of northwest Ghana. In the area of policy - medium-to-long-term, the results show the need for specific land legislations by local and central governments to narrow the customary land rights and land tenure insecurity gap between the vulnerable and privileged groups in local communities. Policies and legislations to empower local institutions, various media and professional legal advocates are equally emphasised. Also, the results show the need for a strong land policy and food policy, particularly food availability. The result show that food availability in this context is capable of facilitating food accessibility, enhancing food nutrition and promoting food stability. Other potentials of this thesis are social harmony, cohesion and peaceful co-existence with less tendency for conflicts. This consequently promotes an enabling socio-political, economic and legal environment at both local and national levels for overall general development and progress of society. These aspects may form the basis of indepth research of this nature in future. 


\section{Samenvatting}

Landrechten in Ghana vinden hun basis in het traditionele grondeigendomssysteem. Zekerheid omtrent grondbezit stimuleert onder andere de beschikbaarheid en het onderhoud van landerijen van voldoende omvang en het productief gebruik daarvan. Deze rechtszekerheid geeft de boeren voldoende vertrouwen voor investeringen in hun boerderij in de wetenschap dat zij van die investeringen zullen profiteren. Dit verhoogt bijgevolg de opbrengst van landbouwproducten hetgeen bijdraagt aan de voedselzekerheid door een verhoogde beschikbaarheid van voedsel. Daarentegen is door externe druk van bevolkingsgroei, verstedelijking en algemene economische ontwikkeling de interne samenhang van de traditionele regelingen en te verzorgen diensten die stabiliteit in grondrelaties niet meer vanzelfsprekend. Deze regelingen bestaan grotendeels uit niet-monetair 'dienstbetoon' in de vorm van geschenken dan wel arbeid, die landgebruikers die niet tot de groep van grondeigenaren behoren, ieder seizoen aan de grondeigenaren moeten voldoen om de eigendomsrechten van de grondeigenaren te erkennen en hun secundaire rechten te vernieuwen en zo hun grondbezit veilig te stellen. De inspanningen van de overheid in het verleden om de voedselzekerheid te bevorderen door landrechten te versterken en zekerheid omtrent grondbezit te vergroten, waren grotendeels gebaseerd op ' geïmporteerd ' beleid van formalisering, registratie of documentatieprocessen. Bij deze inspanningen werd weinig of geen rekening gehouden met de lokale gewoontes, gebruiken of dynamiek van het grondbezit. Als gevolg hiervan waren de verwachte voordelen van deze inspanningen niet of minimaal aanwezig, en dus ontmoedigend en daardoor niet succesvol. Daarom suggereert dit proefschrift een meer pragmatische benadering - om in nauwe samenwerking met de lokale gemeenschap tot een verantwoord en geschikt model te komen voor traditionele landrechten/grondbezit en voedselzekerheid middels co-creatie. Hierbij analyseert de lokale gemeenschap eerst haar eigen lokale regelingen en praktijken rond grondbezit. Daarna leert men over succesvolle modellen elders om zo te komen to co-creatie van een nieuw model door het combineren van de sterke punten van beide zodat het geheel past bij hun lokale behoeften en omstandigheden.

De eerste doelstelling van dit proefschrift keek naar de veranderingen in de landrechten en het grondbezit alsmede de ongelijkheid in rechtszekerheid, en de gevolgen daarvan voor de voedselzekerheid van zelfvoorzienende boeren in het noordwesten van Ghana. Met behulp van de sociale structuurtheorie werd het onderzoek uitgevoerd door middel van diepte-interviews met geïdentificeerde subcategorieën van zulke boeren: gehandicapten, vrouwen, mannen van middelbare leeftijd en jongeren. De specifieke landrechten en rechtszekerheidsniveau van elke groep werden geïdentificeerd en onderzocht. Daarna is ook gekeken naar de implicaties voor de verschillende groepen. De uitkomst was dat er inderdaad aanmerkelijke ongelijkheid is, waarbij mannelijke landeigenaren de sterkste landrechten met de hoogste landeigendomszekerheid bezitten. Verder hebben vrouwen uit de groep van grondeigenaren, die hoger in de sociale structuur van de gemeenschap zijn 
geplaatst, vergelijkbare, zwakke landrechten en een lage rechtszekerheid, met de vrouwen uit de groep van later gevestigde grondgebruikers. Paradoxaal genoeg, hebben de mannen van de later gevestigden, hoewel zij lager in de sociale structuur staan, toch sterkere landrechten en meer rechtszekerheid dan de vrouwen uit de groep van landeigenaren. Dit lijkt erop te wijzen dat het geslacht (gender) de aard van de landrechten en de rechtszekerheid van mensen in het studiegebied meer bepaalt dan enige andere factor dan ook. Zelfs gehandicapt zijn heeft bijvoorbeeld niet zoveel invloed op de landrechten van mensen als hun geslacht (gender). Daarom zijn er meer uitdagingen op het gebied van voedselonzekerheid door beschikbaarheid en toegankelijkheid onder alle vrouwelijke en de mannelijke later gevestigden, nu die over zwakkere landrechten beschikken dan mannelijke landeigenaren die sterkere landrechten hebben. Uiteraard profiteren vrouwen van de landeigenaren deels van die sterkere positie, vergeleken met vrouwen die ook nog eens later gevestigd zijn. De studie concludeerde dat er strategieën moeten worden ontwikkeld om de verschillen in landrechten en ongelijkheid in zekerheid omtrent grondbezit te verkleinen. Dit zal meer investeringen vanuit alle categorieën boeren stimuleren, om landerijen van voldoende omvang te verwerven, te bezitten en te behouden, en investeringen op dat land te bevorderen zodat de opbrengst van landbouwproducten wordt vergroot. Dit kan leiden tot vergrote voedselbeschikbaarheid, hetgeen de voedseltoegankelijkheid kan stimuleren en daarmee ook voedzaamheid en voedselstabiliteit onder de mensen in het gebied kan bevorderen.

De tweede doelstelling bekeek hoe de uitdagingen van de veranderende regelingen omtrent gebruik van grond en verzorgen van diensten door de zelfvoorzienende boeren kunnen worden aangepakt door hun landrechten te versterken, en de rechtszekerheid en daarmee de voedselzekerheid te verbeteren. Hierbij ging het vooral om het onderzoeken van de invloed van interventies in de traditionele landrechten en de rechtszekerheid op de voedselzekerheid in het noordwesten van Ghana. De mate waarin het lokale grondbezitsmodel en de daaraan inherente beperkingen de realisatie van hun menselijke aspiraties inzake zekerheid omtrent grondbezit en voedselzekerheid belemmeren, werd onderzocht. De beperkingen volgen uit het ontbreken van overkoepelende wetgeving, van robuustere informatiestromen, van duidelijke betrokkenheid van de media op het gebied van communicatie, en van interventiemogelijkheden voor later gevestigden om grondbezitsproblemen aan te kaarten, waardoor ze beperkt blijven in hun manier van boeren, in de beschikbaarheid van voedsel en daarmee in hun voedselzekerheid. In nauwe samenwerking met de lokale gemeenschap, kwamen strategieën (zowel lokaal als extern) naar voren die ingevoerd zouden moeten worden om de problemen aan te pakken. De strategieën omvatten handhaving van het lokale landrechtenmodel, maar met daaraantoe te voegen een aantal aspecten voorgesteld in de literatuur. De eerste daarvan is overkoepelende wetgeving om rechtskracht te geven aan de processen in het lokale landrechtenmodel; iets dat aanvankelijk afwezig was. Ten tweede gaat het om het stimuleren van informatiestromen en versterking van communicatie over problemen rond landrechten door (zowel lokale als nationale) media als social media om snel de aandacht te vestigen en op te ropen tot actie door de verantwoordelijke instellingen. Verder dient de toegang tot de rechtbanken voor de gevallen waarin de traditionele aanpak niet in staat is om de armere 
boeren van een bevredigende oplossing inzake problemen met hun landrechten en grondbezit te voorzien, te worden gewaarborgd via een systeem van laagdrempelige juridische medewerkers die hen bijstaan.

Doelstelling drie was de co-creatie van het ontwerp van een nieuw model voor het verbeteren van de rechtszekerheid omtrent grondbezit en voedselzekerheid van zelfvoorzienende, kleinschalige boeren in traditionele gemeenschappen in het gebied. Op basis van de uitkomsten van de eerste en tweede doelstelling, was het doel hier om na te gaan hoe de problemen met het traditionele grondbezit en het verzorgen van diensten door kleinschalige boeren kan worden aangepakt om te komen tot verbeterde rechtszekerheid en voedselzekerheid. Het onderzoek werkte in dit stadium nauw samen met de lokale bevolking en co-creëerde zo een grondbezit model dat als verantwoordelijk en passend (FFP - fit-for-purpose) gekenmerkt mag worden, nu het voortkwam uit de gemeenschap en hun lokale werkwijzen, gebruiken en ideeën de basis van het ontwerp van het model vormden. Door de aard van dit nieuwe model, worden de traditionele landrechten en grondbezitskwesties geïncorporeerd en beïnvloed door de overkoepelende wetgeving. Dit betekent dat elk aspect van het lokale grondbezitsmodel juridisch afdwingbaar zal zijn zodra de nieuwe overkoepelende wetgeving wordt geïmplementeerd na het doorlopen van een testimplementatiefase onder doelstelling vier om de potentiële haalbaarheid ervan in de praktijk te bevestigen.

Doelstelling vier beoogde het testen van de implementatie van het nieuwe verantwoordelijke en passende (FFP) model voor het vergroten van de rechtszekerheid omtrent grondbezit voor alle categorieën van zelfvoorzienende, kleinschalige boeren om de landbouw te bevorderen, zo mogelijk de landbouwproductie te verhogen, zo de beschikbaarheid van voedsel te vergroten en bijgevolg de voedselzekerheid te verbeteren. Bij het testen van het model zijn de verschillende rollen (eigenaren, gebruikers, media, instituties, enzovoort) door de deelnemers uit de gemeenschap (vertegenwoordigers van de verschillende categorieën) nagebootst in verschillende rollenspelsessies. Tijdens zulke sessies werden grondbezitskwesties, problemen en meningsverschillen gepresenteerd. Sommige (lokale) deelnemers namen de rol op zich van een instelling en individu dat verantwoordelijk was voor het aanpakken van de problemen. Tijdens de sessies werden sommige zaken snel opgelost, terwijl andere werden doorverwezen naar het volgende (hogere) niveau zoals vervat in het model; net zolang tot het was opgelost. Alle elementen van het model - rechtbank, advocaten, media enz. werden getest en door de deelnemers goedgekeurd als uitvoerbaar en potentieel effectief voor het versterken van landrechten en voor het veiligstellen van het traditionele grondbezit. De vrijwel unanieme acceptatie bleek uit een hoge score op een Likertschaal, waarbij respectievelijk vier en twee gemeenschappen op instemmend en sterk instemmend uitkwamen.

Concluderend kunnen we stellen dat sterke traditionele landrechten en rechtszekerheid omtrent traditioneel grondbezit belangrijke voorwaarden zijn voor zelfvoorzienende en kleinschalige boeren om tijd, geld en moeite in landbouw te investeren met een grote kans om de hoeveelheid geproduceerde 
voedsel op hun boerderijen te vergroten en daardoor de voedselzekerheid te bevorderen. Natuurlijk spelen ook andere omstandigheden, zoals gunstige regenval, afwezigheid van ongedierte, vruchtbare grond en bemesting, enzovoort, een rol bij het bereiken van voedselzekerheid naast sterke landrechten en een zeker grondbezit. Dit proefschrift draagt bij aan de kennis en literatuur middels empirisch bewijs inzake kwesties rond landrechten, grondbezit en voedselzekerheid van zelfvoorzienende, kleinschalige boeren in het noordwesten van Ghana. Inzake beleidsvorming, van middellange tot lange termijn, tonen de resultaten de noodzaak van specifieke wetgeving rond landrechten op zowel lokaal als nationaal niveau aan, om zo het gebrek aan zekerheid omtrent traditioneel grondbezit te verkleinen voor kwetsbare en kansarme groepen in lokale gemeenschappen. Beleid en wetgeving ter versterking van lokale instituties, uiteenlopende media en professionele juridische medewerkers worden evenzeer benadrukt. De resultaten tonen ook de noodzaak aan van een helder grondbeleid alsmede voedselbeleid, in het bijzonder inzake voedselbeschikbaarheid. Het resultaat laat zien dat voedselbeschikbaarheid in deze context in staat is om voedseltoegankelijkheid te vergemakkelijken, voedzaamheid te verbeteren en voedselstabiliteit te bevorderen. Andere mogelijk uitkomsten van het model uit dit proefschrift zijn sociale harmonie, cohesie en vreedzaam samenleven met minder neiging tot conflicten. Die op hun beurt voor een socio-politieke, economische en juridische setting kunnen zorgen, die zowel op lokaal als op nationaal niveau bijdraagt aan algemene ontwikkeling en vooruitgang van de gehele samenleving. 


\section{CURRICULUM VITAE}

BIO-DATA

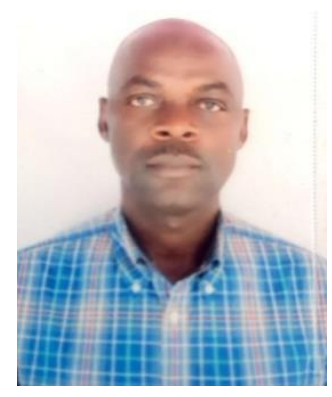

- Full name: Baslyd Begerr Nara

- $\quad$ Date of birth: $27^{\text {th }}$ April, 1968

- Hometown: Nandom-Dangko, UWR, Ghana

- Marital status: Married

- Contact number: +233541590342

- Postal Address:

Department of Real Estate and Land Management University of Business and Integrated Development Studies

P. O. Box UPW3, Wa, Ghana, West Africa

- E-mail addresses:

- bnara@ubids.edu.gh

- bnara@uds.edu.gh

- b.b.nara@utwente.nl

- Current job: Lecturing

- basbnara@yahoo.co.uk

\section{SCHOOLS ATTENDED \& QUALIFICATIONS OBTAINED}

1. PhD in Land Administration and Land Management (University of Twente, The Netherlands, graduating October 2021)

2. MPhil, Land Management (Kwame Nkrumah University of Science and Technology (KNUST), Kumasi, Ghana (2011))

3. BA Integrated Development Studies (University for Development Studies (UDS), Tamale, Ghana (2003))

4. 'A' 3 year Post Secondary Teacher's Certificate (Bagabaga Teacher Training college (BATCO), Tamale, Ghana (1992))

5. GCE Ordinary level (Wa secondary School, Wa, Ghana (1988)) 


\section{WORK EXPERIENCES GATHERED}

- $\quad$ Lecturer, UDS-UBIDS Wa, 2012 -

- Principal Research Assistant, UDS Wa campus, 2009-2012

- Senior Research Assistant, UDS Wa campus, 2004-2009

- Teaching Assistant, UDS Wa campus, 2003-2004

- Classroom Teacher, GES (various locations), 1992-2003

\section{RESEARCH INTERESTS}

1. Land tenure, Land use, Land rights and sustainable livelihoods

2. Land governance and development

3. Food security

\section{TEACHING BACKGROUND}

Pre-tertiary: 11 years teaching in the Ghana Education Service (various subjects)

Tertiary: 15 years teaching in UDS-UBIDS Wa in the following course areas:

1. Land Resource Economics

2. Land tenure

3. Land administration and management

4. Land use planning and administration

5. Customary land law in Ghana

6. Agriculture and Rural Development

7. Elements of Government \& Decentralisation in Ghana

8. Research Methods

\section{RESEARCH CONTRIBUTIONS \& PUBLICATIONS (2014 - 2021)}

1) Assessing customary land rights and tenure security variations of smallholder farmers in northwest Ghana. ELSEVIER-Land Use Policy journal

2) Influences of Community Land Rights and Tenure Security Intervention Processes on Food Security in Northwest Ghana. CRC Press - Taylor \& Francis Group

3) Implications of Customary Land Rights Inequalities for Food Security: A Study of Smallholder Farmers in Northwest Ghana. LAND MDPI journal

4) Addressing the Problems of Land Registration Processes in Complex Land Tenure Systems Using Computational Techniques: Evidence from Accra Ghana

5) The role of Customary Land Secretariats in promoting good local land governance in Ghana. ELSEVIER-Land Use Policy journal 
6) Enhancing Efficiency in Land Management through the Customary Land Secretariats (CLSs) in Upper West Region, Ghana. DEV STUDIES JOURNAL

7) Integrating decentralised land administration systems with traditional land governance institutions in Ghana: Policy and praxis. ELSEVIERLand Use Policy journal

8) Analysis of the role of Customary Land Secretariats in effective land administration in Ghana: The case of Wa Central Customary Land Secretariat. CONFERENCE PAPER - Ethiopia

9) Securing land rights under the tendamba/family customary system of land tenure. The case of Wa Municipality. CONFERENCE PAPER - Lagos, Nigeria

10) Enhancing the space for stakeholder participation in community development: lessons from a community theatre approach in Ghana. LANDac CONFERENCE PAPER - Utrecht, Netherlands

11) Agricultural Land Use Change and Sustainable Livelihoods in Peri Urban Wa. BOOK - ISBN 978-3-659-53336-5 LAP LAMBERT Academic Publishing, Germany

\section{PUBLICATIONS IN PRESS}

1) Designing responsible and fit-for-purpose (FFP) customary land rights and tenure model for food security of smallholder farmers in northwest Ghana - Land Use Policy journal - ELSEVIER

2) Testing a fit-for-purpose (FFP) model for strengthening customary land rights and tenure to improve food security in northwest Ghana - LAND MDPI journal 